\title{
Human Resources FY 1995 Site Support Program Plan WBS 6.10.2
}

Date Published

September 1994

Prepared for the U.S. Department of Energy

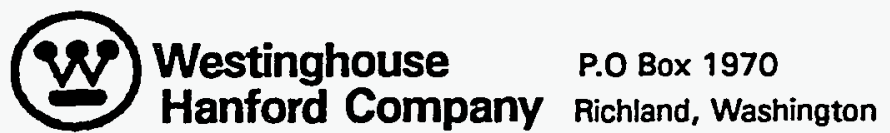

Hanford Operations and Engineering Contractor for the 


\section{DISCLAIMER}

This report was prepared as an account of work sponsored by an agency of the United States Government. Neither the United States Government nor any agency thereof, nor any of their employees, make any warranty, express or implied, or assumes any legal liability or responsibility for the accuracy, completeness, or usefulness of any information, apparatus, product, or process disclosed, or represents that its use would not infringe privately owned rights. Reference herein to any specific commercial product, process, or service by trade name, trademark, manufacturer, or otherwise does not necessarily constitute or imply its endorsement, recommendation, or favoring by the United States Government or any agency thereof. The views and opinions of authors expressed herein do not necessarily state or reflect those of the United States Government or any agency thereof. 


\section{DISCLAIMER}

Portions of this document may be illegible in electronic image products. Images are produced from the best available original document. 


\section{Site Support Program Plan Approval Sheet}

6.10 .2

(Program WBS\#
HUMAN RESOURCES

TitTe)

\section{Assistant Manager-Contracting Officer's Representative}

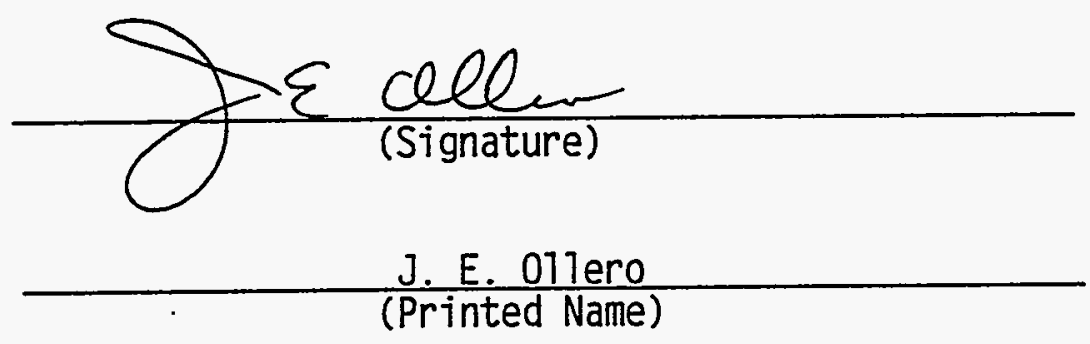

RL Program Manager

$\frac{\text { Sersen A. Costice }}{\text { (Signature) }}$

S. A. Hostick (Printed Name)

WHC Director or VP
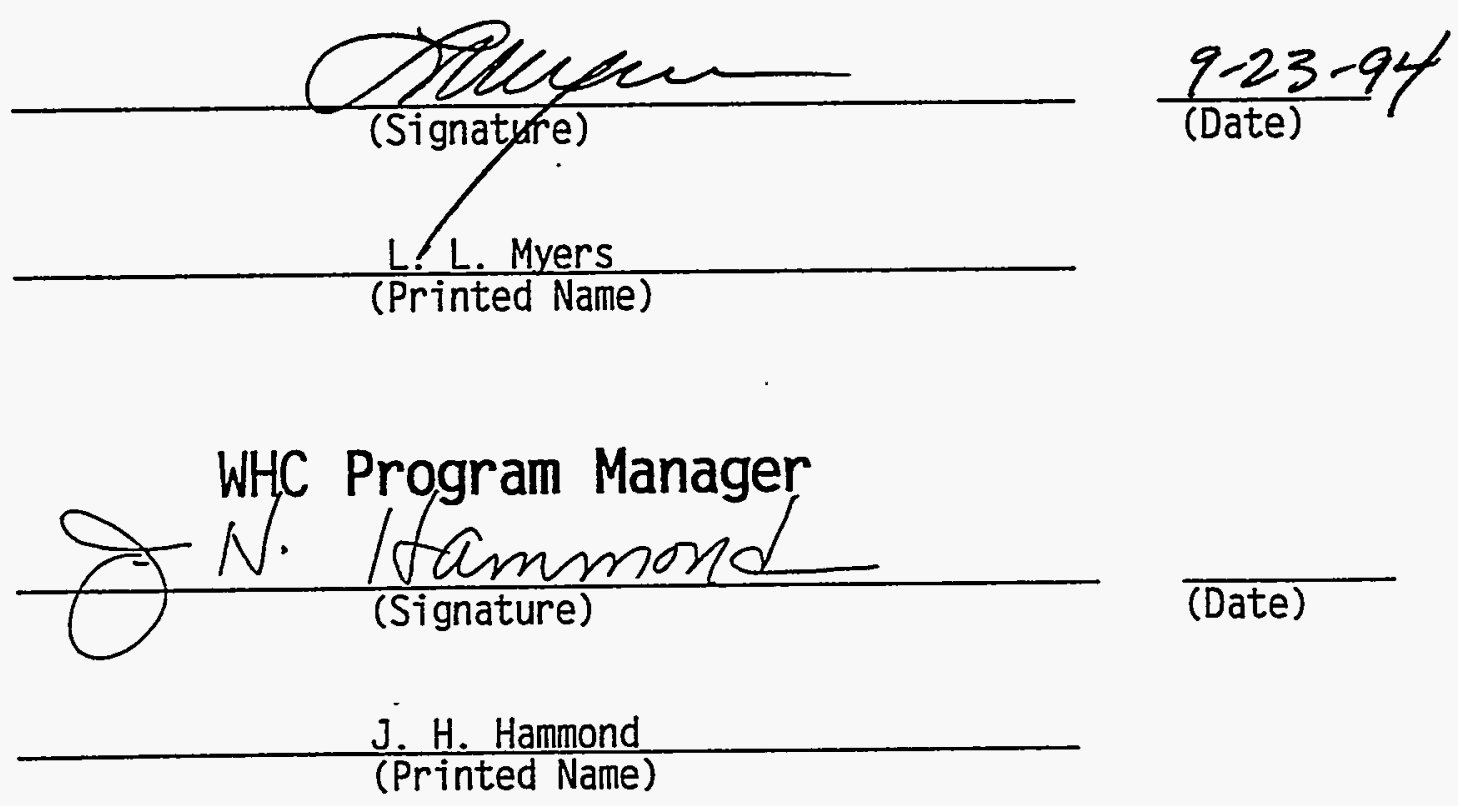


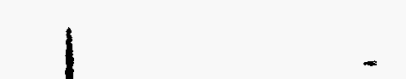

$\because$
$\vdots$
$\vdots$
$\therefore$
$\therefore$
$\therefore$
$\vdots$

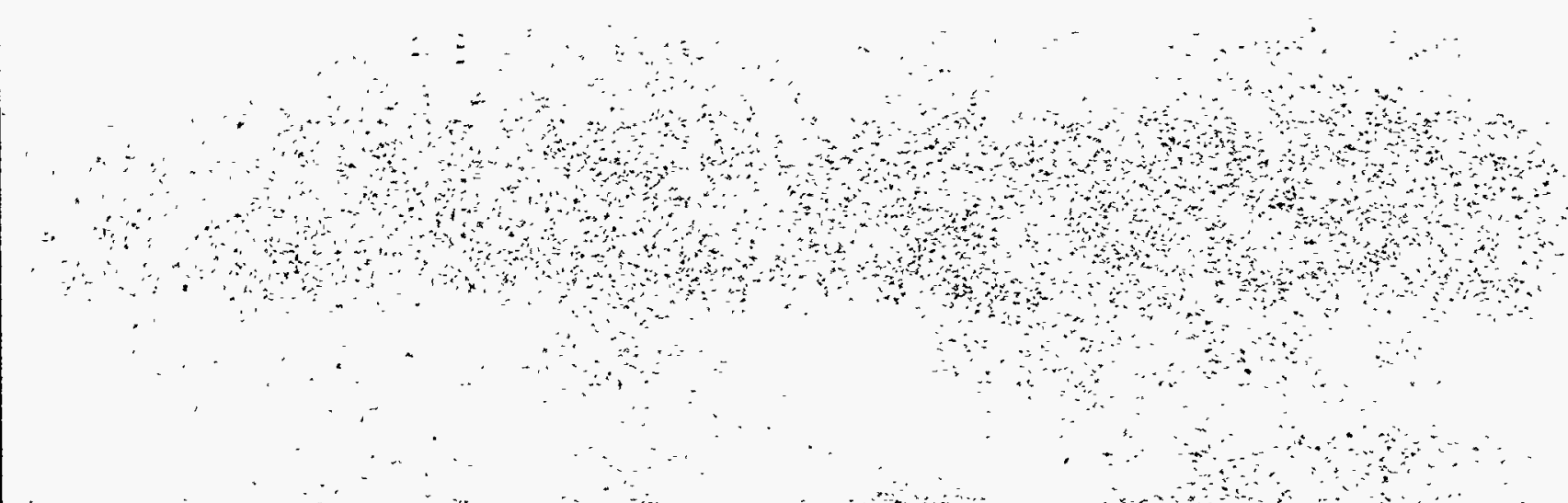

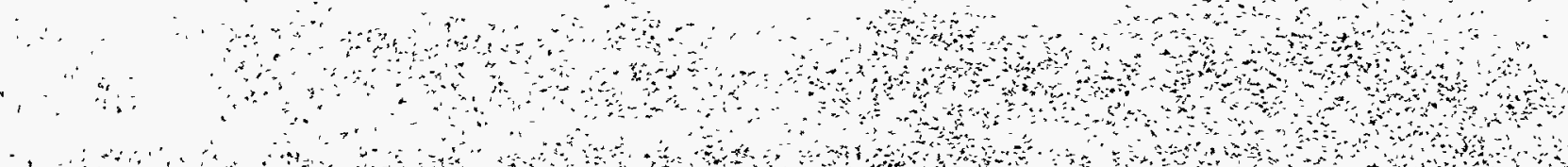
( ) ( (1) (1) ( a a ( )

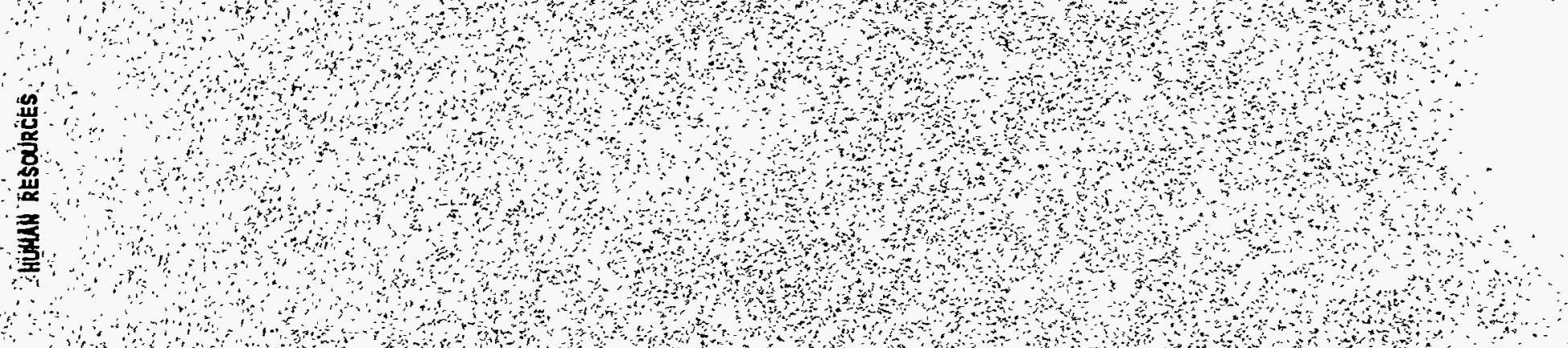
2. 


\begin{tabular}{|l|c|c|}
\hline 1 Program Vision/Mission & $\begin{array}{c}\text { WHC-SP-1121 } \\
\text { Human Resources } \\
\text { SMS/WBS No. 6.10.2 }\end{array}$ & $\begin{array}{c}\text { FY 1995 } \\
\text { Site Support Program Plan } \\
\text { Date Prepared: } 8 / 19 / 94\end{array}$ \\
\hline
\end{tabular}

\section{OVERVIEW}

The Human Resources (HR) support for the Hanford Site is provided by a balanced combination of centralized services and matrixed program/project support personnel. This balanced support concept ensures responsive HR services are available when and where required to support the Department of Energy/Westinghouse Hanford mission at the Hanford Site.

This balanced concept was established by evaluating both the internal capabilities of our resources and performing an external assessment of our customers needs in the context of a competitive service environment with outsourcing as the alternate provider.

The following goals for HR broadly stated establish our direction and basic purpose; to support the DOE mission at the Hanford Site:

- Develop support services to ensure implementation of the Workforce Restructuring Plan.

- Continue to evaluate methods to increase productivity enhancements and identify outsourcing opportunities.

- Identify initiatives that ensure company wide diversity.

- Support the Hanford Workforce PTanning Process

Our strategy for attainment of the above goals will follow a disciplined business/financial approach by applying proven project management principles. 


\begin{tabular}{|c|c|c|}
\hline 1 Program Vision/Mission & $\begin{array}{c}\text { WHC-SP-1121 } \\
\text { Human Resources } \\
\text { SMS/WBS No. } 6.10 .2 \\
\end{array}$ & $\begin{array}{l}\text { FY } 1995 \\
\text { Site Support Program P1an } \\
\text { Date Prepared: } 8 / 19 / 94\end{array}$ \\
\hline
\end{tabular}

\section{ASSUMPTIONS}

The funding and staff requirements identified to accomplish the workscope wil1 be approved.

\section{Performance Measurement}

The performance of HR during FY 1995 will be evaluated by our ability to maintain compliance with our baselines, both cost and schedule, while accomplishing the workscope contained in this document.

Methods used to measure our performance, both interna11y and externally, include the twenty-seven (27) resource loaded milestones and the cost verses budget analysis conducted monthly during the Site Management System Reviews.

It is important to consider that during FY 1994 HR absorbed additional workscope representing a 7 abor demand of 9.0 full time equivalents without formally requesting RL to increase the Fiscal Year Work Plan (FYWP) staffing authorization. This additional workscope is being carried into FY 1995 and is contained in the Description of Activities.

The primary responsibilities of each major organization within HR in support of our common goals and the resource requirements for their accomplishment are contained herein. 


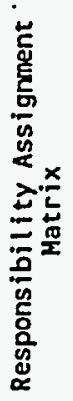




\section{RESPONSIBILITY ASSIGNMENT MATRIX (RAM)}

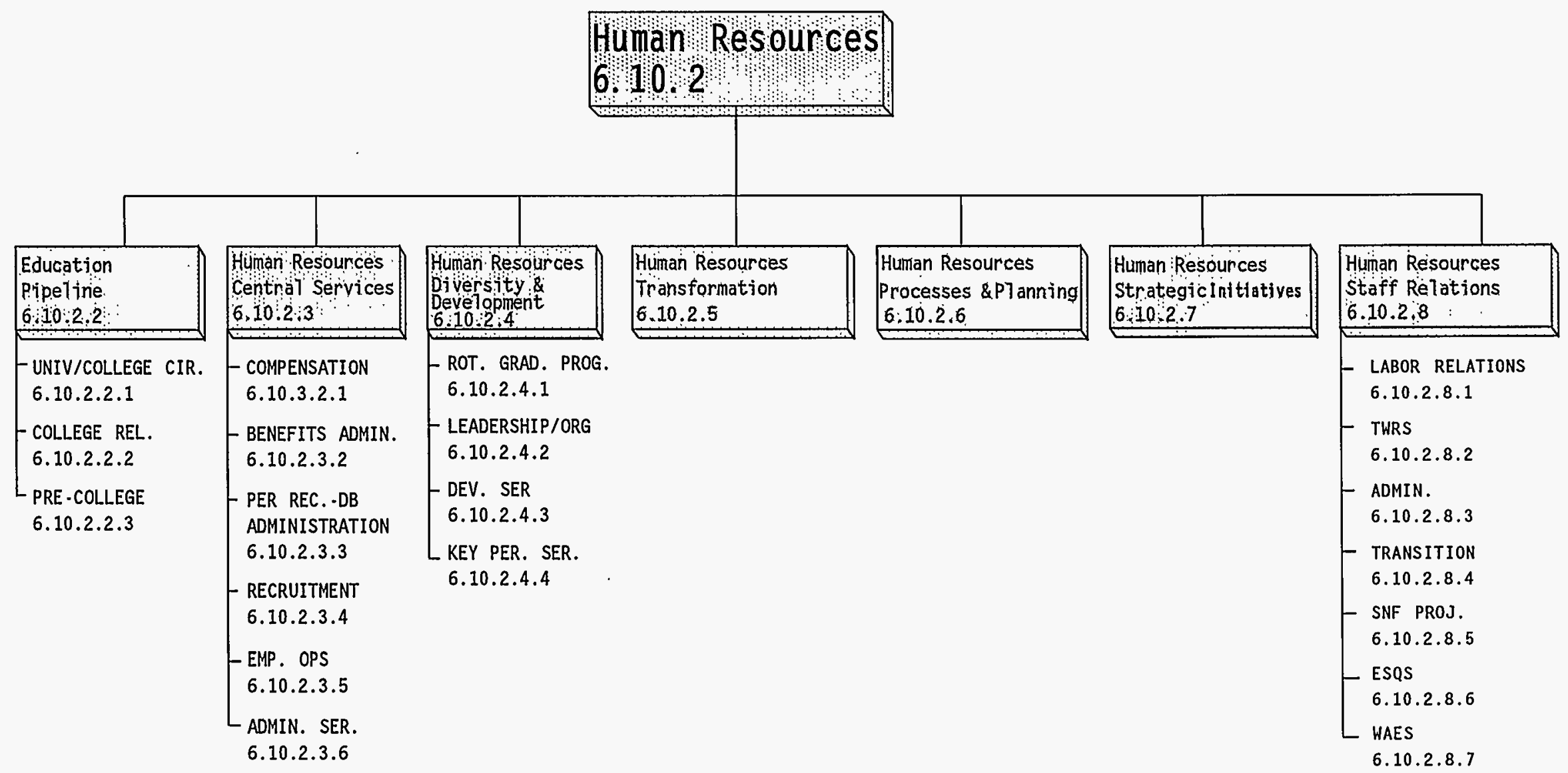




\section{HUMAN RESOURCES MILESTONE LIST}

\begin{tabular}{|c|c|c|c|c|c|c|c|}
\hline $\begin{array}{l}\text { WBS } \\
\text { Number }\end{array}$ & $\begin{array}{l}\text { Milestone } \\
\text { Number }\end{array}$ & Milestone Description & ORGANIZATION TITLE & $\begin{array}{l}\text { Responsible } \\
\text { Manager }\end{array}$ & $\begin{array}{l}\text { Responsible } \\
\text { Organization }\end{array}$ & $\begin{array}{l}\text { Program } \\
\text { Manager }\end{array}$ & RL Manager \\
\hline 6.10 .2 .3 & FAH-95-001 & $\begin{array}{l}\text { Action Plan based on Environmental } \\
\text { Horkforce Transition Model results }\end{array}$ & Central Services & GL Clogston & WHC/TC\&ES & Hawkins/Myers & JE ollero \\
\hline $6.10 \cdot 2.3 .4$ & FAH-95-002 & $\begin{array}{l}\text { Certification of WHC Employment } \\
\text { Recruiters }\end{array}$ & Recruitment & JH Ford & WHC/RECRUIT & Hawkins/Myers & JE ollero \\
\hline $6.10 .2 \cdot 3.3$ & FAH-95-003 & $\begin{array}{l}\text { Applicant tracking Module for } \\
\text { PeopleSOFT }\end{array}$ & $\begin{array}{l}\text { Personnel Records - Database } \\
\text { Administration }\end{array}$ & DE Hansen & $W H C / P R-D A$ & Hawkins/Myers & JE ollero \\
\hline 6.10.2.3.3 & FAH-95-004 & $\begin{array}{l}\text { Prioritization for integration of HR } \\
\text { PeopleSOFT elements }\end{array}$ & $\begin{array}{l}\text { Personnel Records - Database } \\
\text { Administration }\end{array}$ & DE Hansen & WHC/PR-DA & Hawkins/Myers & JE ollero \\
\hline 6.10 .2 .3 .1 & FAH-95-005 & $\begin{array}{l}\text { Cy } 1996 \text { Salary Surveys for salary } \\
\text { planning }\end{array}$ & Compensation & RG Joseph & WHC/COMP & Hawkins/Myers & JE ollero \\
\hline 6.10 .2 .3 .1 & FAH-95-006 & $\begin{array}{l}\text { CY } 1996 \text { Salary Increase Funds } \\
\text { Requests }\end{array}$ & Compensation & RG Joseph & WHC/COMP & Hawkins/Myers & JE ollero \\
\hline 6.10 .2 .3 .1 & FAH-95-007 & Horker's compensation cost basel ine & Compensation & RG Joseph & WHC/COMP & Hawkins/Myers & JE Ollero \\
\hline 6.10 .2 .3 .5 & FAH-95-008 & $5 \%$ reduction in Employment cycle time & Employment Operations & JT Carello & WHC/EO & Hawkins/Myers & JE Ollero \\
\hline 6.10.2.3.2 & FAH-95-009 & $\begin{array}{l}\text { Outsource evaluation for employee and } \\
\text { retiree benefits enrollment process }\end{array}$ & Benefits Administration & JR Sorenson & WHC/BA & Hawkins/Myers & JE ollero \\
\hline 6.10.2.3.2 & FAH-95-010 & $\begin{array}{l}\text { Phase one implementation for modified } \\
\text { retiree health insurance program }\end{array}$ & Benefits Administration & JR Sorenson & WHC/BA & Hawkins/Myers & JE ollero \\
\hline 6.10 .2 .3 .2 & FAH-95-011 & $\begin{array}{l}\text { Heal th Benefits Utilization/Cost } \\
\text { Review }\end{array}$ & Benefits Administration & JR Sorenson & WHC/BA & Hawkins/Myers & JE ollero \\
\hline 6.10 .2 .4 .1 & FAH-95-012 & Current employee rotation process & Rotation Programs & G Mitchell & WHC/RP & Hawkins/Myers & JE ollero \\
\hline 6.10 .2 .4 .3 & FAH-95-013 & FY 1995 Development Prospectus & Development Services & CA Locke & WHC/DS & Hawkins/Myers & JE Ollero \\
\hline 6.10 .2 .4 & FAH-95-014 & BCSR Affirmative Action Plan & $\begin{array}{l}\text { Diversity \& Devel opment } \\
\text { Leadership }\end{array}$ & FA Powers & WHC/D\&DL & Hawkins/Myers & JE Ollero \\
\hline
\end{tabular}

Human Resources Page 4 
HUMAN RESOURCES MILESTONE LIST

\begin{tabular}{|c|c|c|c|c|c|c|c|}
\hline $\begin{array}{l}\text { WBS } \\
\text { Number }\end{array}$ & $\begin{array}{l}\text { Milestone } \\
\text { Number }\end{array}$ & Milestone Description & ORGANIZATION TITLE & $\begin{array}{l}\text { Responsible } \\
\text { Manager }\end{array}$ & $\begin{array}{l}\text { Responsible } \\
\text { Organization }\end{array}$ & $\begin{array}{l}\text { Program } \\
\text { Manager }\end{array}$ & RL Manager \\
\hline 6.10 .2 .4 & FAH-95-015 & WHC Affirmative Action Plan & $\begin{array}{l}\text { Diversity \& Development } \\
\text { Leadership }\end{array}$ & FA Powers & HHC/D\&DL & Hawkins/Myers & JE ollero \\
\hline 6.10 .2 .4 & FAH-95-016 & $\begin{array}{l}\text { Integrated Strategic Plan for } \\
\text { Diversity }\end{array}$ & $\begin{array}{l}\text { Diversity \& Development } \\
\text { Leadership }\end{array}$ & FA Powers & HHC/D\&DL. & Hawkins/Myers & JE Ollero \\
\hline 6.10 .2 .6 & FAH-95-017 & Site Support Program Plan & HR Processes \& Planning & JH Harmond & HHC/HRP\&P & Hawkins/Myers & JE Ollero \\
\hline 6.10 .2 .6 & FAH-95-018 & HHC Staffing Plan & HR Processes \& Planning & JH Hammond & WHC/HRP\&P & Hawkins/Myers & JE Ollero \\
\hline 6.10 .2 .7 & FAH-95-019 & WHC HR FY 1996-1998 Strategic Plan & HR Strategic Initiatives & RW Holleran & WHC/HRSI & Hawkins/Myers & JE Ollero \\
\hline 6.10 .2 .8 .4 & FAH-95-020 & $\begin{array}{l}\text { Personnel disposition/transition } \\
\text { during U0-3 closure }\end{array}$ & HR Transition Projects & GF Saskowsky & WHC/HR-TP & Hawkins/Myers & JE ollero \\
\hline 6.10 .2 .8 .4 & FAH-95-021 & $\begin{array}{l}\text { Power Operator Training and } \\
\text { Qual ification Program }\end{array}$ & HR Transition Projects & GF Saskowsky & HHC/HR-TP & Hawkins/Myers & JE Ollero \\
\hline 6.10 .2 .8 .4 & FAH-95-022 & $\begin{array}{l}\text { Transition Projects training on labor } \\
\text { agreement (HAMTC) }\end{array}$ & HR Transition Projects & GF Saskowsky & WHC/HR-TP & Hawkins/Myers & JE Ollero \\
\hline 6.10 .2 .8 .1 & FAH $-95-023$ & Labor/Management Cooperation Program & Labor Relations & BD Corder & HHC/LR & Hawkins/Myers & JE Ollero \\
\hline 6.10 .2 .8 .5 & FAH-95-024 & HR Staff Relations Rotational Program & HR Spent Nuclear Fuel Project & JT Eckert & WHC/HR-SNFP & Hawkins/Myers & JE ollero \\
\hline 6.10 .2 .8 .6 & FAH-95-025 & Targeted Skill Enhancement Program & $\begin{array}{l}\text { HR Emergency, Safety, Quality } \\
\text { Services }\end{array}$ & KA Hill & WHC/HR-ESQS & Hawkins/Myers & JE ollero \\
\hline 6.10 .2 .8 .1 & FAH-95-026 & $\begin{array}{l}\text { HGU Strategic Bargaining Plan for } \\
\text { Hage Reopener }\end{array}$ & Labor Relations & $\begin{array}{l}\text { FA Blowe/ } \\
\text { BD Corder }\end{array}$ & HHC/LR & Hawkins/Myers & JE ollero \\
\hline 6.10.2.8.1 & FAH-95-027 & $\begin{array}{l}\text { Pre-negotiations planning for alcohol } \\
\text { testing for Commercial Drivers } \\
\text { License compliance }\end{array}$ & Labor Relations & $\begin{array}{l}\text { FA Blowe/ } \\
\text { BD Corder }\end{array}$ & WHC/LR & Hawkins/Myers & JE ollero \\
\hline
\end{tabular}


1 


\begin{tabular}{||c|c|c|}
\hline \hline SSPP & WESTINGHOUSE HANFORD COMPANY & 1995 \\
SCHEDULE & 6.10.2 HUMAN RESOURCES & \\
\hline
\end{tabular}

MILESTONE SCHEDULE

FISCAL YEAR 1995

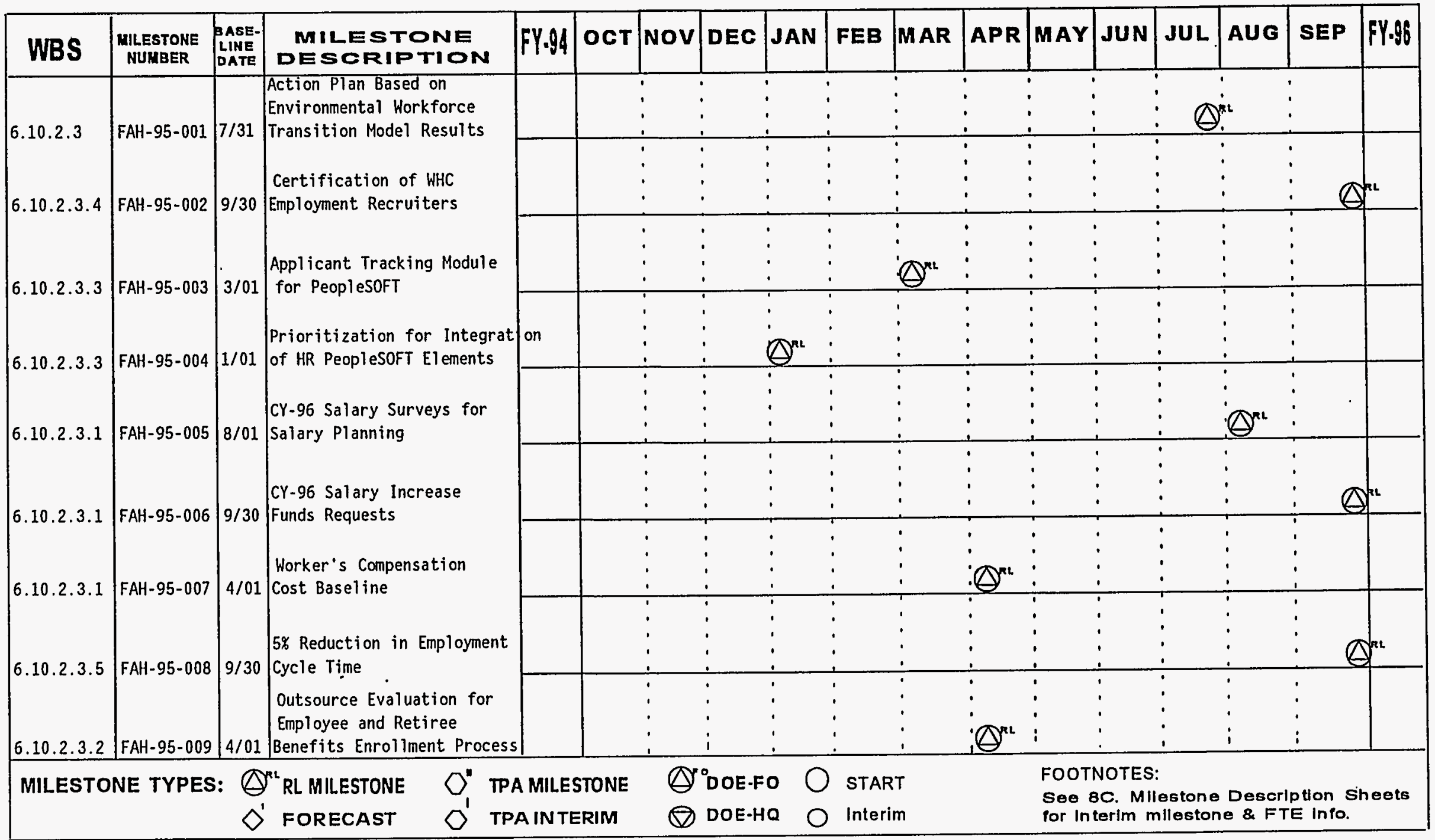




\begin{tabular}{|c|c|c||}
\hline \hline SSPP & WESTINGHOUSE HANFORD COMPANY \\
SCHEDULE \\
BASELINE
\end{tabular}$\quad$\begin{tabular}{c} 
6.10.2 HUMAN RESOURCES \\
\hline
\end{tabular}

MILESTONE SCHEDULE

FISCAL YEAR 1995

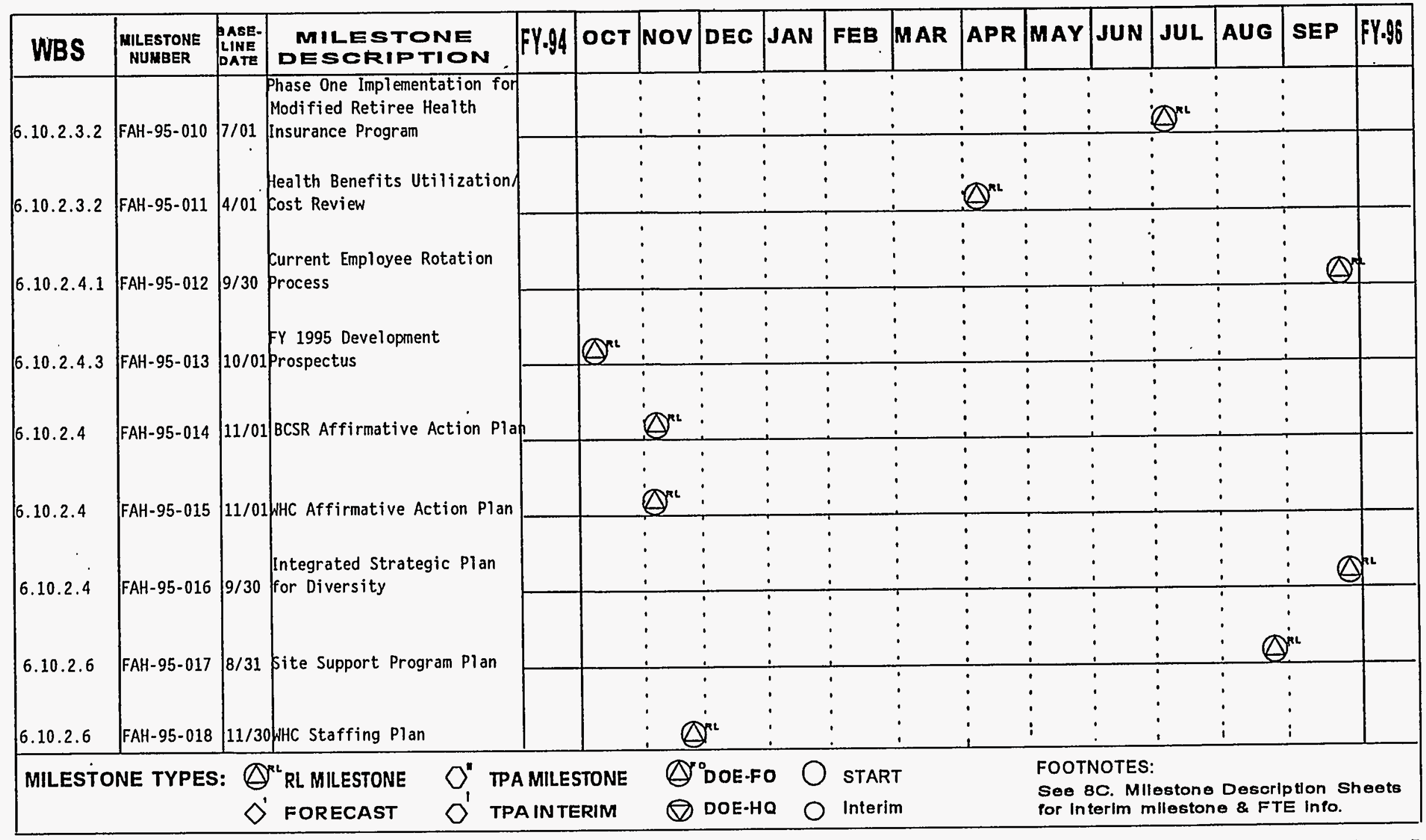




\begin{tabular}{|c|c|c|}
\hline \hline SSPP \\
$\begin{array}{c}\text { SCHEDULE } \\
\text { BASELINE }\end{array}$ & $\begin{array}{c}\text { WESTINGHOUSE HANFORD COMPANY } \\
\text { 6.10.2 HUMAN RESOURCES }\end{array}$ & 1995 \\
\hline
\end{tabular}

MILESTONE SCHEDULE

FISCAL YEAR 1995

\begin{tabular}{|c|c|c|c|c|c|c|c|c|c|c|c|c|c|c|c|c|c|}
\hline WBS & $\begin{array}{l}\text { MILESTONE } \\
\text { NUMBER }\end{array}$ & $\begin{array}{l}\text { BASE- } \\
\text { LINE } \\
\text { DATE }\end{array}$ & $\begin{array}{l}\text { MILESTONE } \\
\text { DESCRIPTION }\end{array}$ & FY.94 & OCT & NOV & DEC & JAN & FEB & MAR & APR & MAY & JUN & JUL & $\overline{A \cup G}$ & SEP & FY.96 \\
\hline 6.10 .2 .7 & FAH-95-019 & $9 / 30$ & $\begin{array}{l}\text { WHC HR FY 1996-98 } \\
\text { Strategic Plan }\end{array}$ & & & . & & ' & & : & : & : & : & : & : & $\otimes$ & \\
\hline $6.10 \cdot 2.8 .4$ & FAH-95-020 & $2 / 01$ & $\begin{array}{l}\text { Personnel Disposition/ } \\
\text { Transition During U03 Closur }\end{array}$ & & & $\vdots$ & & ? & $\theta^{n}$ & $\vdots$ & : & . & ! & : & & & \\
\hline 6.10 .2 .8 .4 & FAH-95-021 & $2 / 01$ & $\begin{array}{l}\text { Power Operator Training and } \\
\text { Qualification Program }\end{array}$ & & & : & : & $\%$ & $\Delta^{\mathrm{nt}}$ & : & : & $\cdot$ & & : & $\div$ & : & \\
\hline 6.10 .2 .8 .4 & FAH-95-022 & $6 / 01$ & $\begin{array}{l}\text { Transition Projects Training } \\
\text { on Labor Agreement (HAMTC) }\end{array}$ & & & $\vdots$ & : & . & . & : & : & ? & $\otimes^{\mathrm{rL}}$ & : & $\vdots:$ & . & \\
\hline 6.10 .2 .8 .1 & FAH-95-023 & $3 / 01$ & $\begin{array}{l}\text { Labor/Management } \\
\text { Cooperation Program }\end{array}$ & & & $\vdots$ & 1 & : & & $\Delta^{n 2}$ & : & : & : & : & $\vdots$ & : & \\
\hline 6.10 .2 .8 .5 & FAH-95-024 & $9 / 30$ & $\begin{array}{l}\text { HR Staff Relations } \\
\text { Rotational Program }\end{array}$ & & & : & $T$ & $\vdots$ & : & 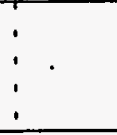 & $:$ & $\vdots$ & : & : & $\vdots$ & : & \\
\hline 6.10 .2 .8 .6 & FAH-95-025 & $9 / 30$ & $\begin{array}{l}\text { Targeted Skill Enhancement } \\
\text { Program }\end{array}$ & & & $\vdots$ & : & $\vdots$ & $\vdots$ & $\vdots$ & $:$ & : & $:$ & : & $\vdots$ & & \\
\hline 6.10 .2 .8 .1 & FAH-95-026 & $9 / 30$ & $\begin{array}{l}\text { HGU Strategic Bargaining } \\
\text { Plan for Wage Reopener }\end{array}$ & & & : & $\therefore$ & i & & $\vdots$ & $:$ & $\therefore$ & - & . & $\vdots$ & & \\
\hline 6.10.2.8.1 & FAH-95-027 & $11 / 01$ & $\begin{array}{l}\text { Pre-negotiatons Plan for } \\
\text { Alcohol Testing for Cormerc } \\
\text { Orivers License Compliance }\end{array}$ & a & & $: \otimes^{\mathrm{re}}$ & & & : & $\vdots$ & : & i & & $\vdots$ & $\vdots$ & $\vdots$ & \\
\hline MILEST & NE TYPE & 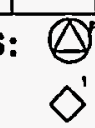 & $\begin{array}{lll}\text { RL RL MILESTONE } & \bigcirc^{\prime \prime} \text { TPA } \\
\text { FORECAST } & 0^{\prime} \text { TPA }\end{array}$ & $\begin{array}{l}\text { A MIL } \\
\text { A IN }\end{array}$ & $\begin{array}{l}\text { STONE } \\
\text { ERIM }\end{array}$ & $\theta$ & $\begin{array}{l}\text { DOE-F } \\
\text { DOE-H }\end{array}$ & $\begin{array}{l}0 \\
10\end{array}$ & $\begin{array}{l}\text { STAR } \\
\text { Interir }\end{array}$ & & & \multicolumn{6}{|c|}{$\begin{array}{l}\text { FOOTNOTES: } \\
\text { See BC. Millestone Desorlption sheets } \\
\text { for Interim mllestone \& FTE info. }\end{array}$} \\
\hline
\end{tabular}




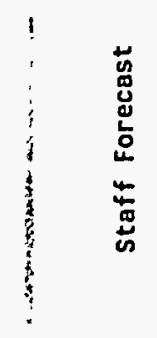




\section{HUMAN RESOURCES}

FORM 2.C.3 FTES

\begin{tabular}{|c|c|c|c|c|c|c|c|c|}
\hline Full-Time Equivalent Sta & y Job D & cription & & NOTE: Jol & Family & Only Afte & 1996 & \\
\hline JoB faMtLY & $\therefore$ & $\sqrt{1}$ & ४ै। & अै। & ४ै। & ४ै। & अै। & बा \\
\hline Job category & 1994 & 1995 & 1996 & 1997 & 1998 & 1999 & 2000 & 2001 \\
\hline MANAERS & $\because$ & 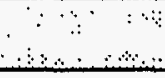 & आै। & $25.0 \%$ & $25: 0$ & 3250 & 250 & 25.0 \\
\hline First line & & 9.0 & 9.0 & & & & & \\
\hline General/executive & & 16.0 & 16.0 & & & & & \\
\hline Project/Program & & 1.0 & & & & & & . \\
\hline other & & & & & & & & \\
\hline ENNGINEERS & & & 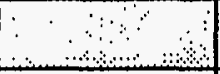 & $\begin{array}{lll}\because & \ddots & \vdots \\
& & \end{array}$ & @ & अ? & יa & अ \\
\hline Chemical & & & & & & & & \\
\hline Civil & & & & & & & & \\
\hline Computer & & & & & & & & \\
\hline Electrical & & & & & & & & \\
\hline Environmental & & & & & & & & \\
\hline Industrial & & & & & & & & \\
\hline Mechanical & & & & & & & & \\
\hline Nuclear & & & & & & & & \\
\hline Petroleum/Mining & & & & & & & & \\
\hline Plant & & & & & & & & \\
\hline Quality Control & & & & & & & & \\
\hline Safety & & & & & & & & \\
\hline other & & & & & & & & \\
\hline
\end{tabular}




\begin{tabular}{|c|c|c|c|c|c|c|c|c|}
\hline \multicolumn{4}{|c|}{ Ful1-Time Equivalent Staff by Job Description } & \multicolumn{5}{|c|}{ NOTE: Job Family Only After 1996} \\
\hline GOB FAMTLY Y, & " & & 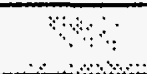 & : & 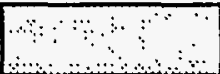 & ए। & +ి.s? & in: \\
\hline Job category & 1994 & 1995 & 1996 & 1997 & 1998 & 1999 & 2000 & 2001 \\
\hline scientisis & $\because \because \because$ & $:$ & ओ & औ্: & ? & अ४ & s?: & 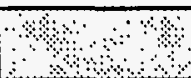 \\
\hline \multicolumn{9}{|l|}{ Chemists } \\
\hline \multicolumn{9}{|l|}{ Environmental } \\
\hline \multicolumn{9}{|l|}{ Geologists } \\
\hline \multicolumn{9}{|l|}{ Life } \\
\hline \multicolumn{9}{|l|}{ Material } \\
\hline \multicolumn{9}{|l|}{ Mathematicians } \\
\hline \multicolumn{9}{|l|}{ Physicists } \\
\hline \multicolumn{9}{|l|}{ Social } \\
\hline \multicolumn{9}{|l|}{ other } \\
\hline ADMHTHNOTHER PROFESS SONALS & & & & 61.0 & $\therefore \quad 58.0$ & $58: 0$ & $58.0 \%$ & 58:0:3 \\
\hline \multicolumn{9}{|l|}{ Accountant/audi tor } \\
\hline \multicolumn{9}{|l|}{ Architect } \\
\hline \multicolumn{9}{|l|}{ Buyers/procurement } \\
\hline \multicolumn{9}{|l|}{ Communications } \\
\hline \multicolumn{9}{|l|}{ Compliance inspectors } \\
\hline \multicolumn{9}{|l|}{ Computer System Anal } \\
\hline \multicolumn{9}{|l|}{ Cost Est/planner/sch } \\
\hline Heal th Physics & & & & & & & & \\
\hline
\end{tabular}




\begin{tabular}{|c|c|c|c|c|c|c|c|c|}
\hline \multicolumn{4}{|c|}{ Full-Time Equivalent Staff by Job Description } & \multicolumn{5}{|c|}{ NOTE: Job Family Only After 1996} \\
\hline JoB FAMFLY $\quad$ U & $\because$ & & 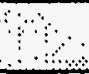 & $\therefore$ & $\because \quad 3$ & अै। & अ? & : \\
\hline Job category & 1994 & 1995 & 1996 & 1997 & 1998 & 1999 & 2000 & 2001 \\
\hline Industrial Hygiene & & & & & & & & \\
\hline Lawyers & & & & & & & & \\
\hline Personnel/Labor Rela & & 62.0 & 60.0 & & & & & \\
\hline Physicians & & & & & & & & \\
\hline Physician Assis/Nurs & & & & & & & & \\
\hline Safeguard \& Security & & & & & & & & \\
\hline Tech Writers \& Edit & & & & & & & & \\
\hline Trainers & & & & & & & & \\
\hline other Temporary & & 1.0 & 1.0 & & & & & \\
\hline JOB FAMILY & & & & & 3 & ४ै। & ४ै & और \\
\hline Job category & & & & & & & & \\
\hline GEN ADM/SECRETARY/CLERK & & & & 52.6 & 52.6 & 326 & 32,6 & 526 \\
\hline Admin Assistants & & & & & & & & \\
\hline Office Clerks (Gen) & & 3.5 & 3.5 & & & & & \\
\hline Office Clerks (Special) & & 25.0 & 25.0 & & & & & \\
\hline Secretaries & & 16.0 & 16.0 & & & & & \\
\hline Typist/Word Process & & & & & & & & \\
\hline other Temporary & & 8.1 & 8.1 & & & & & \\
\hline TECHN & & & & & & & & \\
\hline
\end{tabular}




\section{HUMAN RESOURCES}

FORM 2.C.3 FTES

\begin{tabular}{|c|c|c|c|c|c|c|c|c|}
\hline Fu11-Time Equivalent Staf & by Jot & ipti & & NOTE : & Family & Only Afte & 1996 & \\
\hline JoB FAMtLY $\quad \cdots \quad$ : & $\because$ & & $\cdots$ & 8 & ४ & ४ै। & ४ै। & \% \\
\hline Job category & 1994 & 1995 & 1996 & 1997 & 1998 & 1999 & 2000 & 2001 \\
\hline Computer Oper/coder & & & & & & - & & \\
\hline Drafters & & & & & & & & \\
\hline Engrs/Tech & & & & & & & & \\
\hline Envir. Sci Technicians & & & & & & & & \\
\hline Heal th Phys. Technic. & & & & & & & & \\
\hline Indus. Saf/Heal th Tech & & & & & & & & \\
\hline Instru/Control Tech & & & & & & & & , \\
\hline Lab. Technicians & & & & & & & & \\
\hline Media Technicians & & & & & & & & \\
\hline Survey/Map Tech & & & & & & & & \\
\hline other & & & & & & & & \\
\hline CRAFTS & & & & & 3 & अ & $\because \therefore$ & $\therefore \because$ \\
\hline Carpenters & & & & & & & & \\
\hline Electricians & & & & & & & & \\
\hline HVAC & & & & & & & & \\
\hline Machinists & & & & & & & & \\
\hline Masons & & & & & & & & \\
\hline Millwrights & & & & & & & & \\
\hline Painters & & & & & & & & \\
\hline
\end{tabular}




\begin{tabular}{|c|c|c|c|c|c|c|c|c|}
\hline \multicolumn{4}{|c|}{ Ful1-Time Equivalent Staff by Job Description } & \multicolumn{5}{|c|}{ NOTE: Job Family Only After 1996} \\
\hline JoB: FAnfLY & $\therefore$ & & - & 3 & ני। & @is & ?४: & e? \\
\hline Job category & 1994 & 1995 & 1996 & 1997 & 1998 & 1999 & 2000 & 2001 \\
\hline \multicolumn{9}{|l|}{ Plumbers/Pipefitters } \\
\hline \multicolumn{9}{|l|}{ Struct/Metal Workers } \\
\hline \multicolumn{9}{|c|}{ Vehic./Mob Equip Mech } \\
\hline \multicolumn{9}{|l|}{ Helders } \\
\hline \multicolumn{9}{|l|}{ other } \\
\hline OP ERATTORS & & & 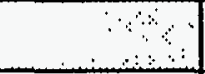 & $\because$ & 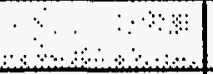 & औल & ४ै। & अध \\
\hline \multicolumn{9}{|l|}{ Chemical System } \\
\hline \multicolumn{9}{|l|}{ Drillers } \\
\hline \multicolumn{9}{|l|}{ Lt. Vehicle Drivers } \\
\hline \multicolumn{9}{|c|}{ Material Moving Equip } \\
\hline \multicolumn{9}{|l|}{ Nuclear Plant } \\
\hline \multicolumn{9}{|c|}{ Utilities Waste Proces } \\
\hline \multicolumn{9}{|l|}{ other } \\
\hline \multicolumn{9}{|l|}{ LABOK \& GEN WORKERS } \\
\hline \multicolumn{9}{|l|}{ Firefighters } \\
\hline \multicolumn{9}{|l|}{ Food Service } \\
\hline \multicolumn{9}{|l|}{ Hand/Help Lab Gen } \\
\hline \multicolumn{9}{|l|}{ Hand/Help Lab Spec } \\
\hline Janitors/Cleaners & & & & & & & & \\
\hline
\end{tabular}




\begin{tabular}{|c|c|c|c|c|c|c|c|c|}
\hline \multicolumn{4}{|c|}{ Fu11-Time Equivalent Staff by Job Description } & \multicolumn{5}{|c|}{ NOTE: Job Family Only After 1996} \\
\hline JoB PAMALY & $\cdots$ & & $\therefore$ & 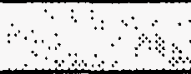 & अ. & अ४: & +ै। & अ. \\
\hline Job category & 1994 & 1995 & 1996 & 1997 & 1998 & 1999 & 2000 & 2001 \\
\hline \multicolumn{9}{|l|}{ Laundry Workers } \\
\hline \multicolumn{9}{|l|}{ Security Guards } \\
\hline \multicolumn{9}{|l|}{ other } \\
\hline TOTAL & * 139.9 & 141.6 & 138.6 & 138.6 & 135.6 & 135.6 & 135.6 & 135.6 \\
\hline
\end{tabular}

* Approved 1994 Fiscal Year Work Plan 
f..., - 


\begin{tabular}{|c|c|c|}
\hline COST AC. & & \\
\hline $\begin{array}{l}\text { Work Breakdown } \\
\text { Structure } \\
\text { Dictionary }\end{array}$ & $\begin{array}{l}\text { Westinghouse Hanford Company } \\
\text { Security Operations Administration } \\
\text { Part II - Element Definition }\end{array}$ & $\begin{array}{c}\text { FY } 1995 \text { SSSP } \\
\text { Revision \#0 }\end{array}$ \\
\hline
\end{tabular}

WBS ELEMENT CODE: 6.10 .2

TITLE: Human Resources

\section{ELEMENT TASK DESCRIPTION}

\section{COST CONTENT}

This cost account provides Human Resources support for the Hanford Site is provided by a balanced combination of centralized services and matrixed program/project support personnel.

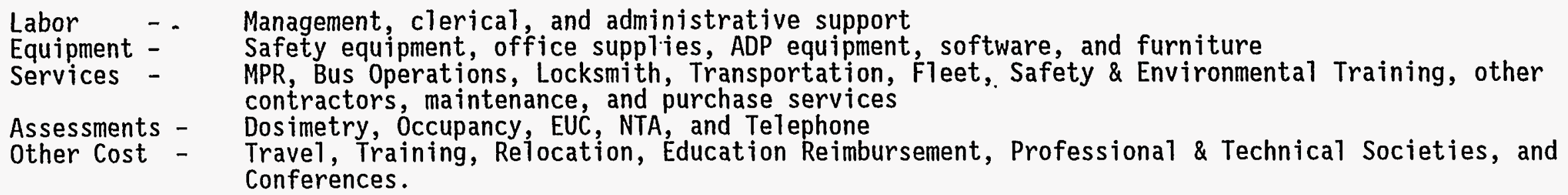

\section{TECHNICAL CONTENT}

Human Resources provides a wide variety of comprehensive programs and services to support the Hanford mission in the following areas: (1) Recruiting and Staffing; (2) Equal Employment Opportunity and Workforce Diversity; (3) Training and Development; (4) Compensation and Benefits; (5) Labor and Employee Relations and Education Outreach activities.

\section{OBJECTIVES}

Human Resources evaluated both the internal capabilities of our resources and performed an external assessment of our customers needs in the context of a competitive service environment with outsourcing as the alternate provider. 0ur objective is to follow a disciplined business/financial approach by applying proven project management principies.

\section{ASSUMPTIONS/CONSTRAINTS}

The funding and staff requirements identified to accomplish the workscope will be approved.

\section{MILESTONES}

See the listing of milestones on page 4

\section{DELIVERABLES}

Numerous reports, the identification of which is contained in the Detail by Organization. 
Westinghou. Hanford Company 1995 Site Support Program Plan

Human Resources SMS - 6.10.2

(Dollars in 000's)

\begin{tabular}{|c|c|c|}
\hline & & IONAL \\
\hline TITLE & AMOUNT & FTE's \\
\hline Funding General \& Administrative & & \\
\hline $\begin{array}{lr}\text { 1MDD4H } & \text { HR Systems } \\
\text { 1MDD46 Human Resources }\end{array}$ & $\begin{array}{r}1,299 \\
11,775\end{array}$ & $\begin{array}{r}0.0 \\
136.2\end{array}$ \\
\hline TOTAL G \& A & $\$ 13,074$ & 136.2 \\
\hline Funding: Department overtiead & & \\
\hline $\begin{array}{l}\text { 1J4110 Grad Rotallonal Prog } \\
\text { I J4800 Administrative Services }\end{array}$ & $\begin{array}{l}718 \\
645\end{array}$ & $\begin{array}{l}3.0 \\
3.0\end{array}$ \\
\hline TOTAL DOH & $\$ 1,363$ & 6.0 \\
\hline TOTAL $H . R_{1} \ldots$ & $\$ \$ 14 ; 47$ & 1422 \\
\hline
\end{tabular}

* Includes 1 Bargaining Unit FTE for Administrative Review 


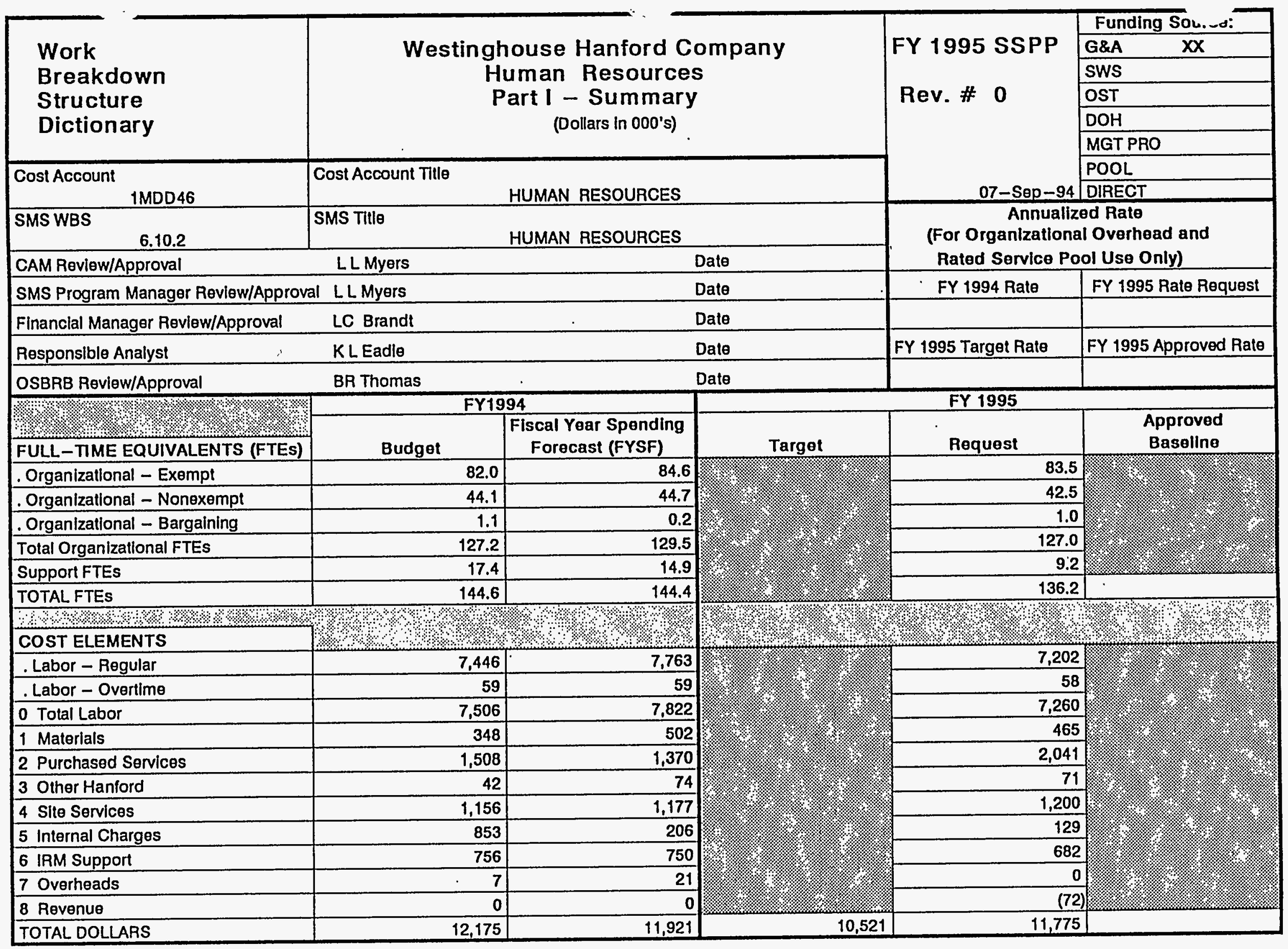




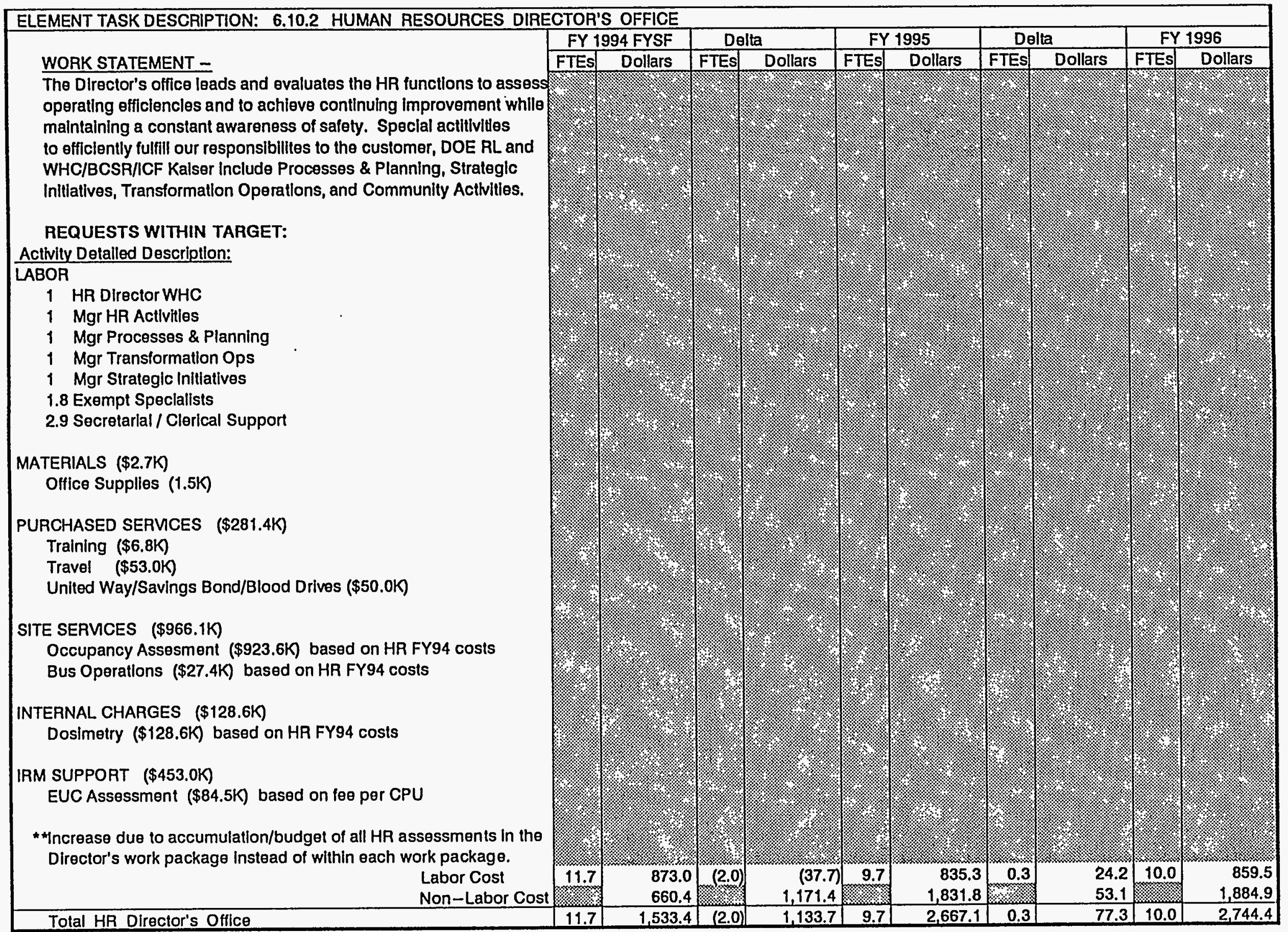




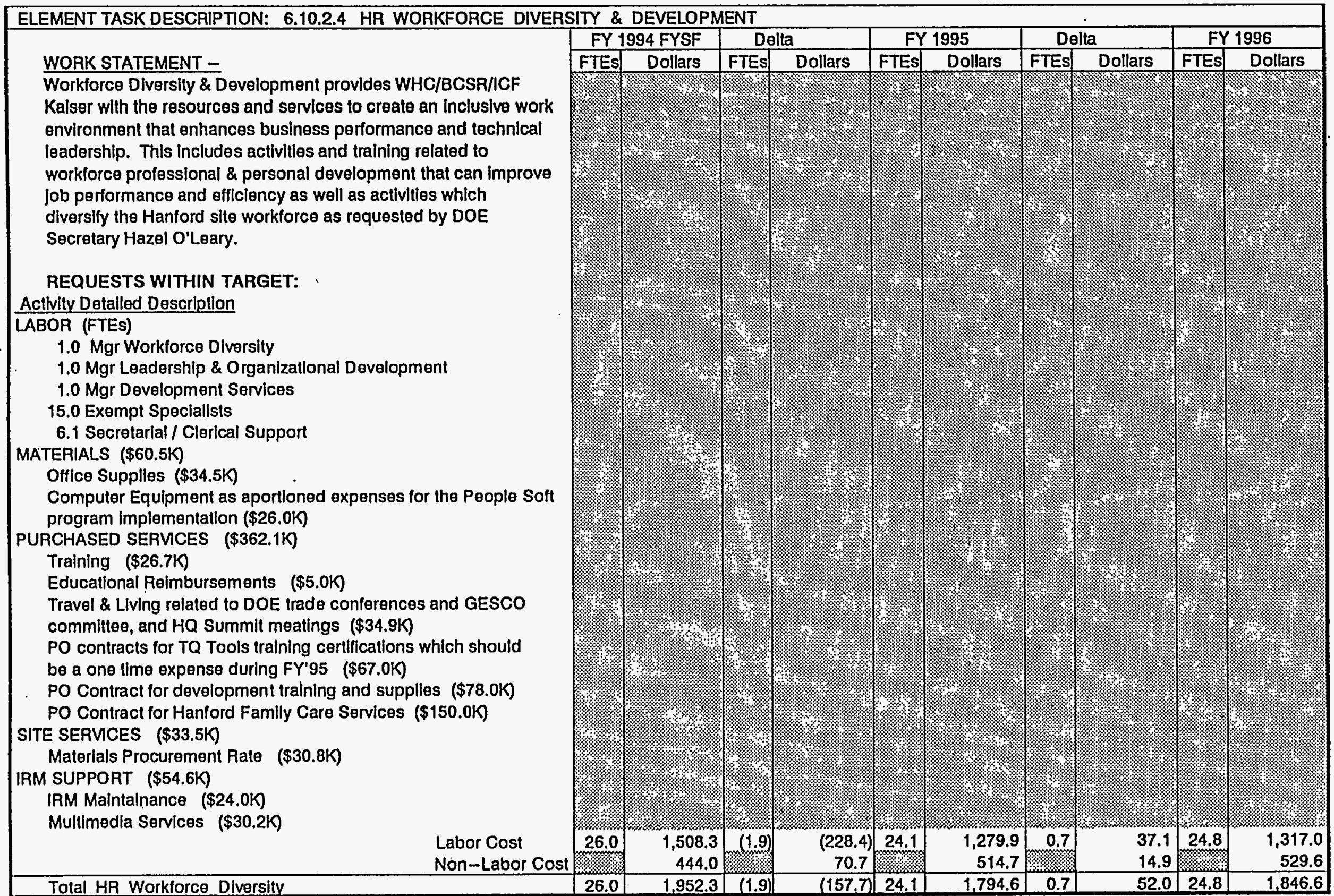




\section{WORK STATEMENT -}

The mission of HA Central Services is to provide highly

responsive, efficient, and cost-effeclive programs and services required by our customers in meeling and exceeding DOE and WHC strategic and operating objectives for Compensation,

Benefits Administration, Recruitment, Employment Operations, Personnel Records and Database Admlnistration, and Administralive Services.

REQUESTS WITHIN TARGET:

Activity Detalled Description

LABOR (\$2749.6K)

1.0 Mgr HR Central Services

1.0 Mgr Compensation.

1.0 Mgr Benefits Administration

1.0 Mgr Personnel Records/Data Administration

1.0 Mgr Recrultment

1.0 Mgr Employment Operations

23.9 Exempt Specialists (HR Representatives)

23.3 Secretarial/ Clerical Support

6.0 Nonexempt Temporary (Student Interns/Temps)

1.0 Bargaining Unit

MATERIALS (\$344.8K)

Office Supplies / Materials \& Equipment (\$223.2)

Computer Hardware / Software (\$121.6K)

PURCHASED SERVCES (\$527.2K)

Tralning \& Certifications $(\$ 82.8 \mathrm{~K})$

Educational Reimbursements (\$9.0K)

Travel \& Living . (\$146.1K)

Local Meetings / Conferences (\$0.8K)

PO Contracts (\$206.3K)

Legal \& Misc Foes (\$73.0K) \& Freight Charges (\$9.2K)

OTHER CONTRACTOR CHARGES (\$11.8K)

PNL - - Subscriptions (\$8.3K) \& ICF Kalser (\$3.5K)

SITE SERMCES (\$111.5K)

Includes MPP, Floet, Locksmith, Transportation for equipment/ office moves, and Safety/Environmental \& QTAC training

IRM SUPPORT (\$112.5K)

Includes Records Management, Computer Malntainence, and Multimedia Services

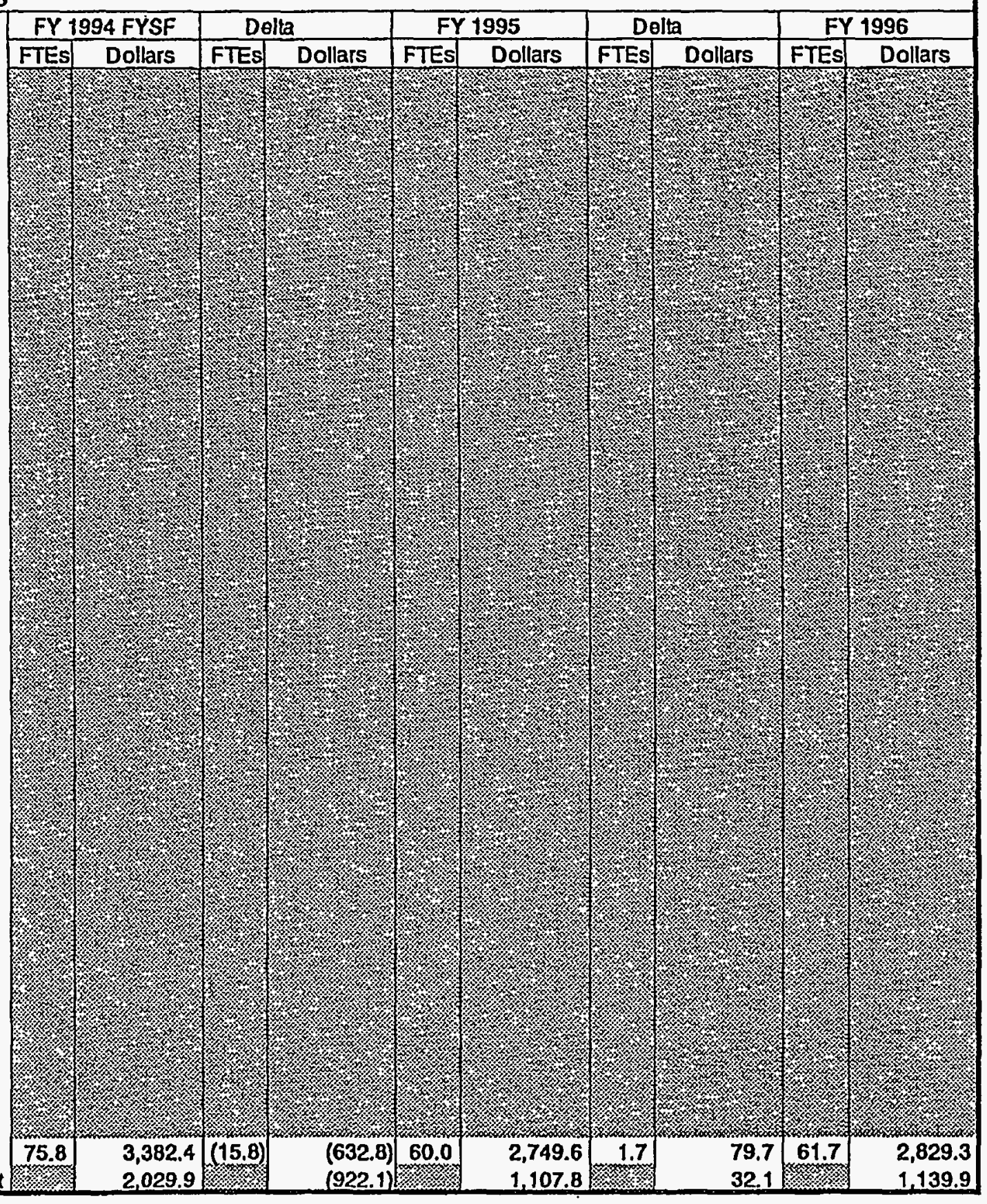




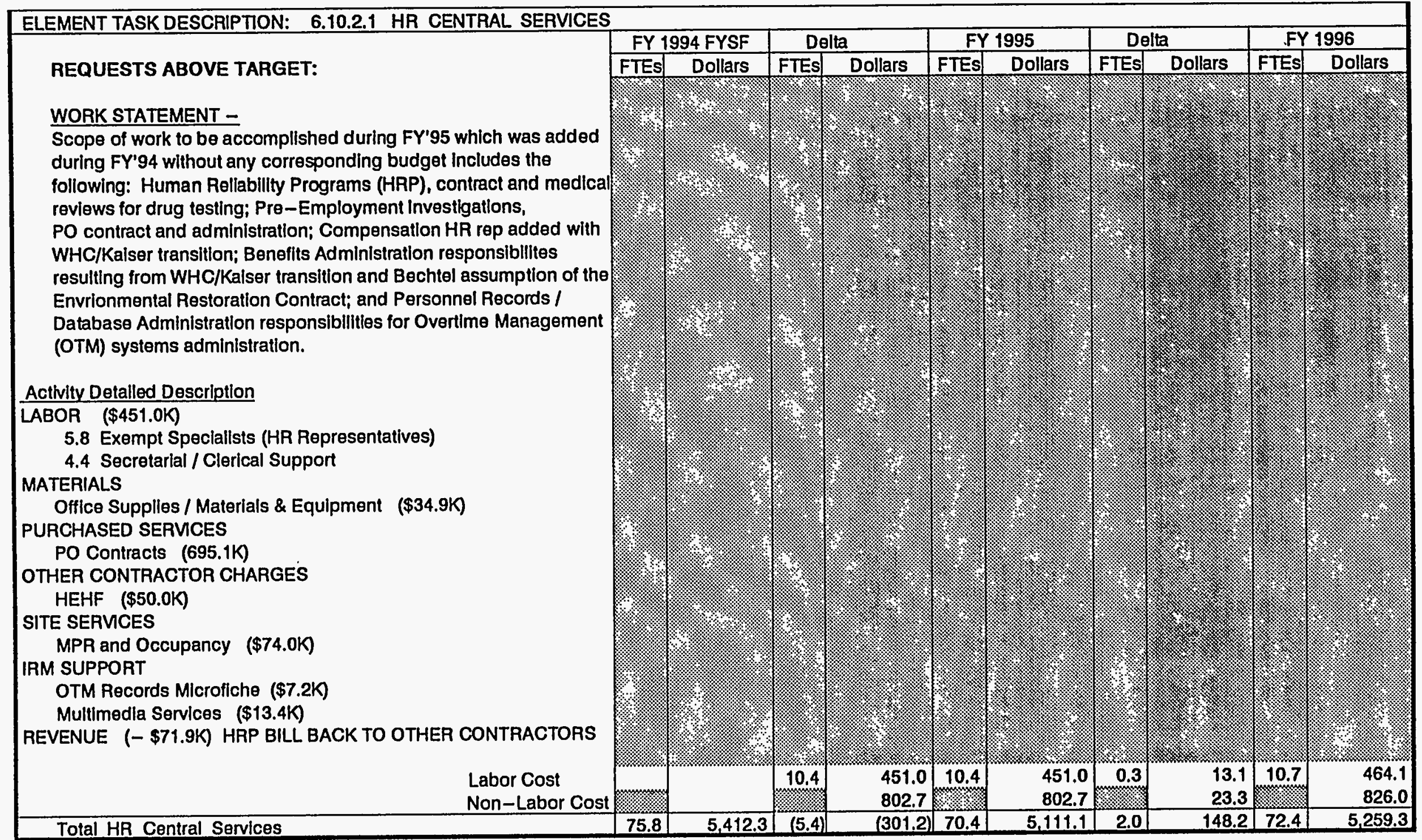




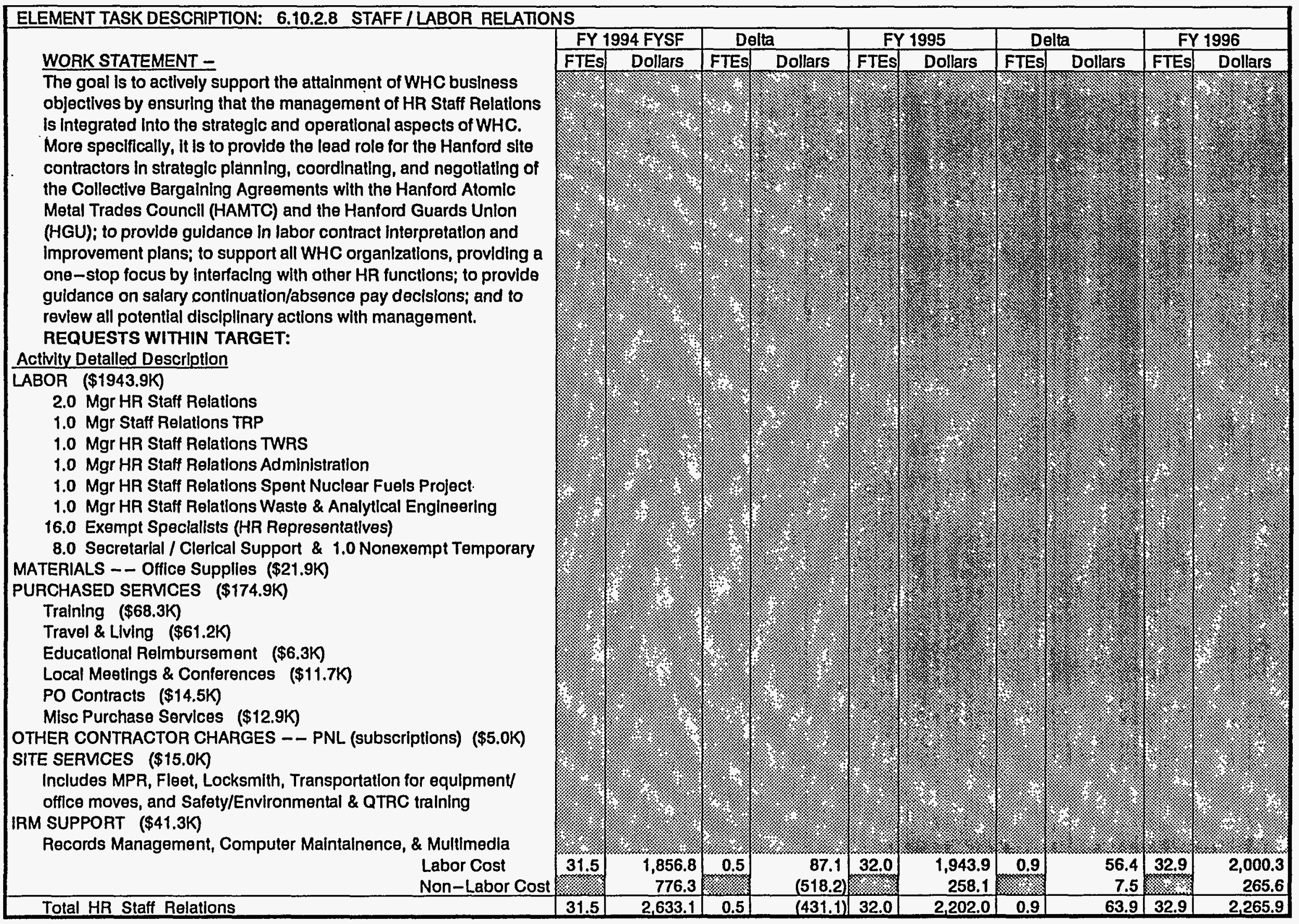




\section{Cost Account: 1MDD46}

Part II - Element Definition (continued)

\begin{tabular}{|c|c|c|c|c|c|c|c|c|c|c|c|}
\hline \\
\hline \multicolumn{12}{|c|}{ ELEMENT TASK DESCRIPTION: 6.10 .2 SUMMARY } \\
\hline & & \begin{tabular}{|l|l|} 
FTES \\
\end{tabular} & Dollars & FTES & Dollars & FTES & Dollars & FTES & Dollars & FTES & Dollars \\
\hline 6.10 .2 & HUMAN RESOURCES DIRECTOR'S OFFICE & 11.7 & $1,533.4$ & (2.0) & $1,133.7$ & 9.7 & $2,667.1$ & 0.3 & 77.3 & 10.0 & $2,744.4$ \\
\hline 6.10.2.1 & HR CENTAAL SERVICES & 75.8 & $5,412.3$ & (5.4) & (301.2) & 70.4 & $5,111.1$ & 2.0 & 148.2 & 72.4 & $5,259.3$ \\
\hline 6.10 .2 .4 & HR WORKFORCE DIVERSITY \& DEVELOPMENT & 26.0 & 1,952.3 & (1.9) & (157.7) & 24.1 & $1,794.6$ & 0.7 & 52.0 & 24.8 & $1,846.6$ \\
\hline 6.10 .2 .8 & STAFF / LABOR RELATIONS & 31.5 & $2,633.1$ & 0.5 & (431.1) & 32.0 & $2,202.0$ & 0.9 & 63.9 & 32.9 & $2,265.9$ \\
\hline Total & Cost Account & 145,0 & 11.531 .1 & $(8.8)$ & 243.7 & 136.2 & $11,774.8$ & 4.0 & 341.5 & 140.2 & 12.116 .3 \\
\hline
\end{tabular}




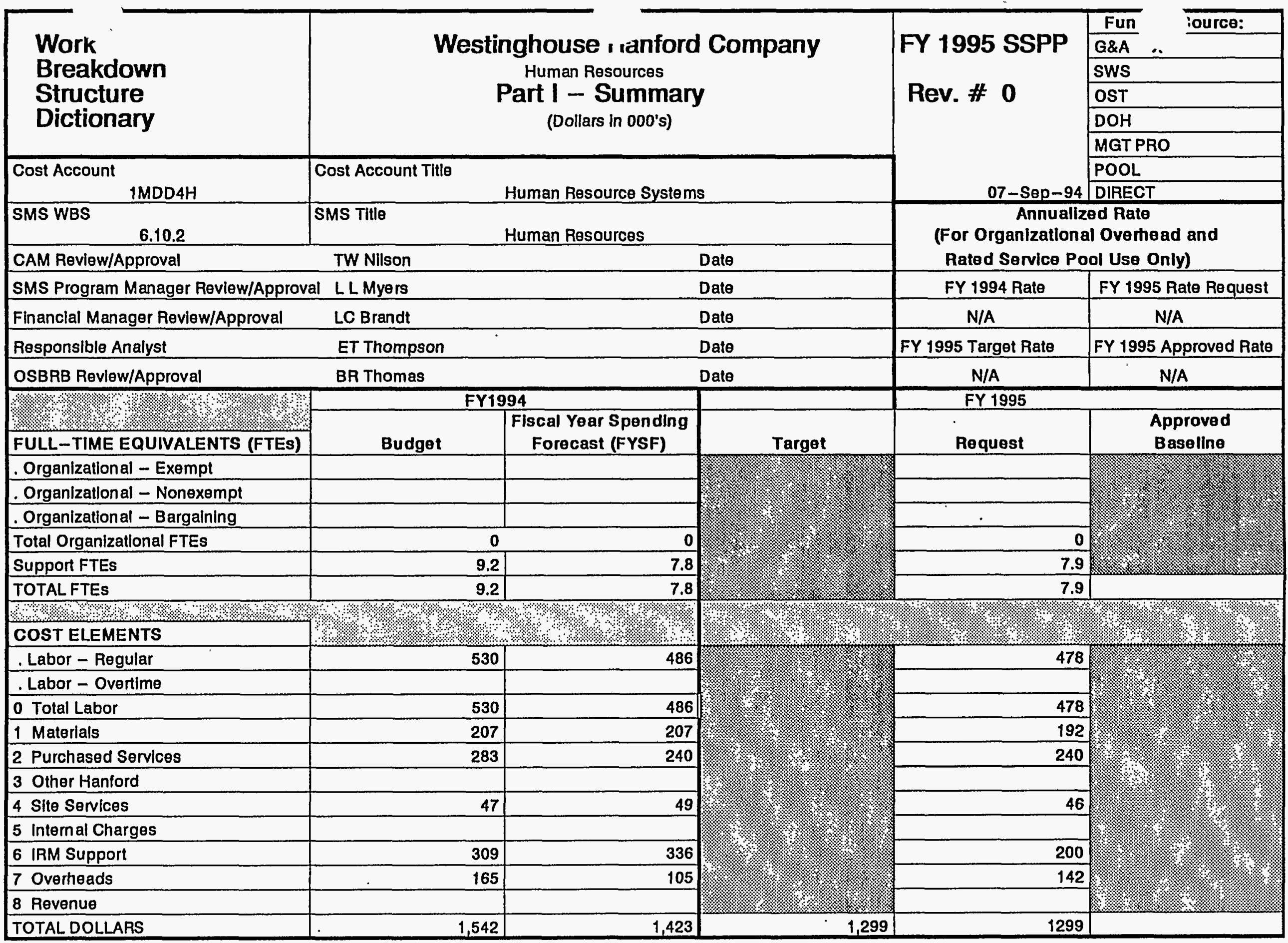




\section{Work Breakdown Structure Dictionary}

\section{Westinghouse Hanford Company}

Human Resources

Part II - Element Definition
FY 1995 SSPP

Revision \# 0

\section{WBS ELEMENT CODE: $\mathbf{1 . 0 6 . 0 0 , 1 0 . 0 2}$ TITLE: Human Resources}

ELEMENT TASK DESCRIPTION

COST CONTENT - $\quad$ This element was included in the General and Administratlve (G\&A) cost accounts 1MDD4D and 1MDD17 in FY 1994. The fund source for this element in FY 1995 is G\&A. Budget target from 1MDD4D is $\$ 1031.8 \mathrm{~K}$ and from 1 MDD17 Is $\$ 267.0 \mathrm{~K}$.

TECHNICAL CONTENT - This element funds the operation, maintenance, enhancement and development of the Westinghouse Hanford Company (WHC) Human Resource Systems, which Includes Human Resources use of the Westlnghouse Human Resource system (WHR); operation and maintenance of the Filness For Duty, Employment Tracking and PC Salary Planning systems; and the Implementation of an Integrated human resource system using a vendor software package from the PeopleSoft Corporatlon. Thls system is scheduled to be implemented by the end of FY 1994 and will replace the use of WHR by the Human Resources organization. Enhancements to the system during FY 1995 and FY 1996 using the vendor software are planned to replace the Fitness For Duty, Employment Tracking, and PC Salary Planning systems and automate and integrate many manual and stand-alone systems currently in use in the Human Resources organization.

The majority of these funds pay for internal services from BCS Richland, Inc. (BCSR) - primarily labor and central computer operatlons. These funds also cover WHC Personnel Systems labor (providing systems analysis, management, and clerical support), purchased materials, computer hardware/software and services necessary to support the the Human Resource systems.

The primary WHC manuals that this work is to comply with are Software Practices (CM-3-10), Data Administration Standards (CM-2-6), and Management Requirements and Procedures (CM-1-3). These WHC manauals are based on several Department of Energy (DOE) Orders that are referenced within them. Also, the human resource functlon supported by the systems has its own regulatory drivers, which carry over into requirements that must be met by the systems.

OBJECTIVES - $\quad$ Provide stable, cost-effective systems that meet customer requirements and are in compllance with regulatory drivers.

\section{ASSUMPTIONS/CONSTRAINTS -}

Minimal staffing change in the Personnel Systems organization. Adequate staffing levels within BCSR (or outsourced staff). Rates and adders consistent with those provided on June 28, 1994, as the FY 1995 planning rates. BCSR central faclity computing rates In FY 1995 are reduced from the FY 1994 rates, consistent with the level of FY 1994 passback of central faclity computing over-liquidations. Escalation rates per June 15, 1994 Controller guldance.

MILESTONES Implement the PeopleSoft Employment module to replace the current Employment Tracking system. (3/1/95) Provide support for developing a priority list to determine successive as well as possible concurrent implementation of other other PeopleSoft Human Resource modules. (1/1/95) 


\section{WORK STATEMENT -}

\section{REQUESTS WITHIN TARGET:}

Activity Detalled Description

WHC systems analyst, BCSR programmer, central computer, network access and computer hardware/software for the operation and maintenance of the WHC Human Resource systems.

Activity Detailed Description.

WHC systems analyst, BCSR programmer, central computer, network access and computer hardware/software for the implementation and enhancement of an Integrated human resource system using the PeopleSoft software package.

$$
\text { Labor Cost }
$$

Activity Detalled Description

Non-Labor Cost

WHC management, student/summer employee and administration support for the operation, maintenance and enhancement of the WHC Human Resource systems.

REQUESTS ABOVE TARGET:

Activity Detalled Description

None.

Labor Cost Non-Labor Cost

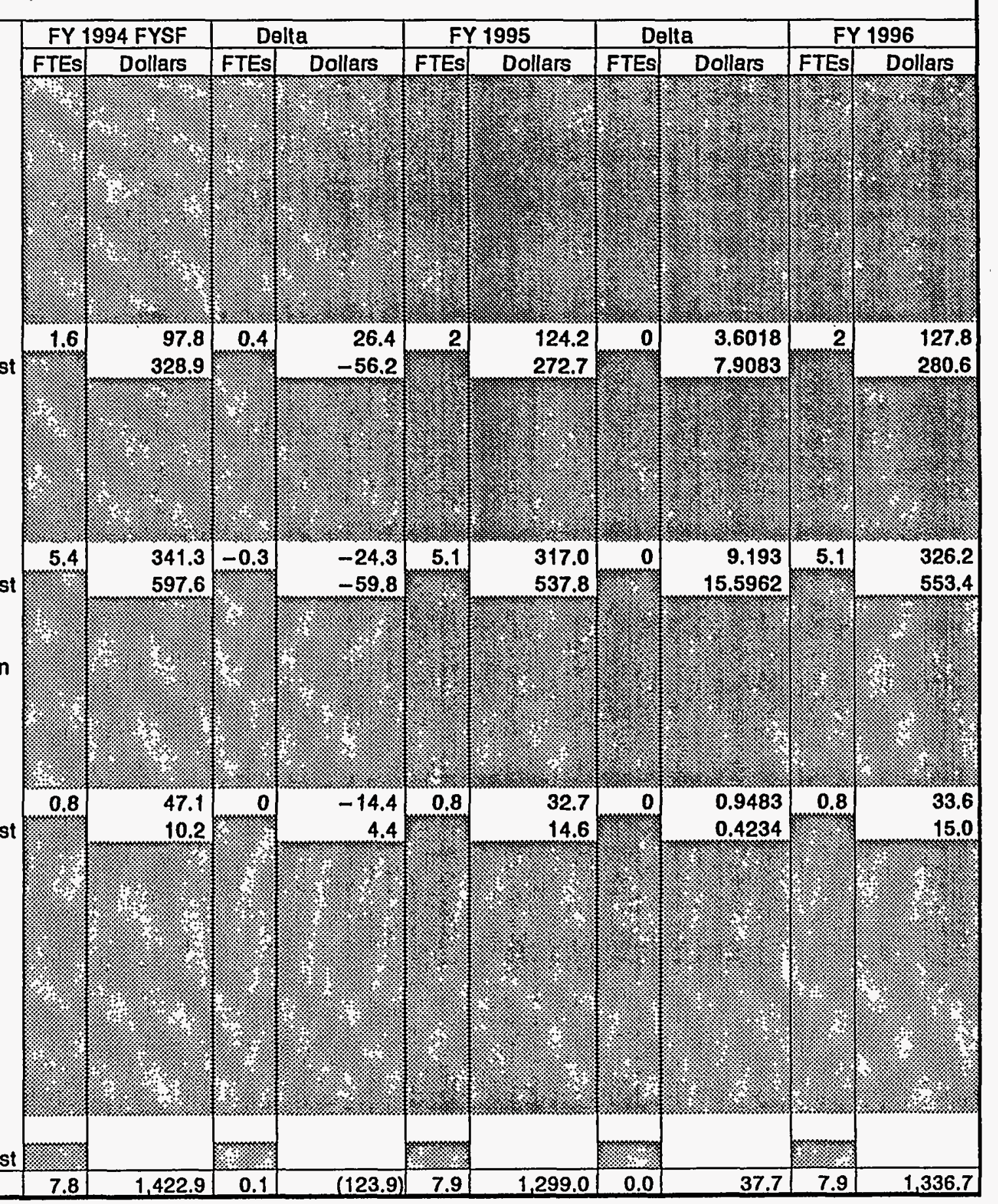




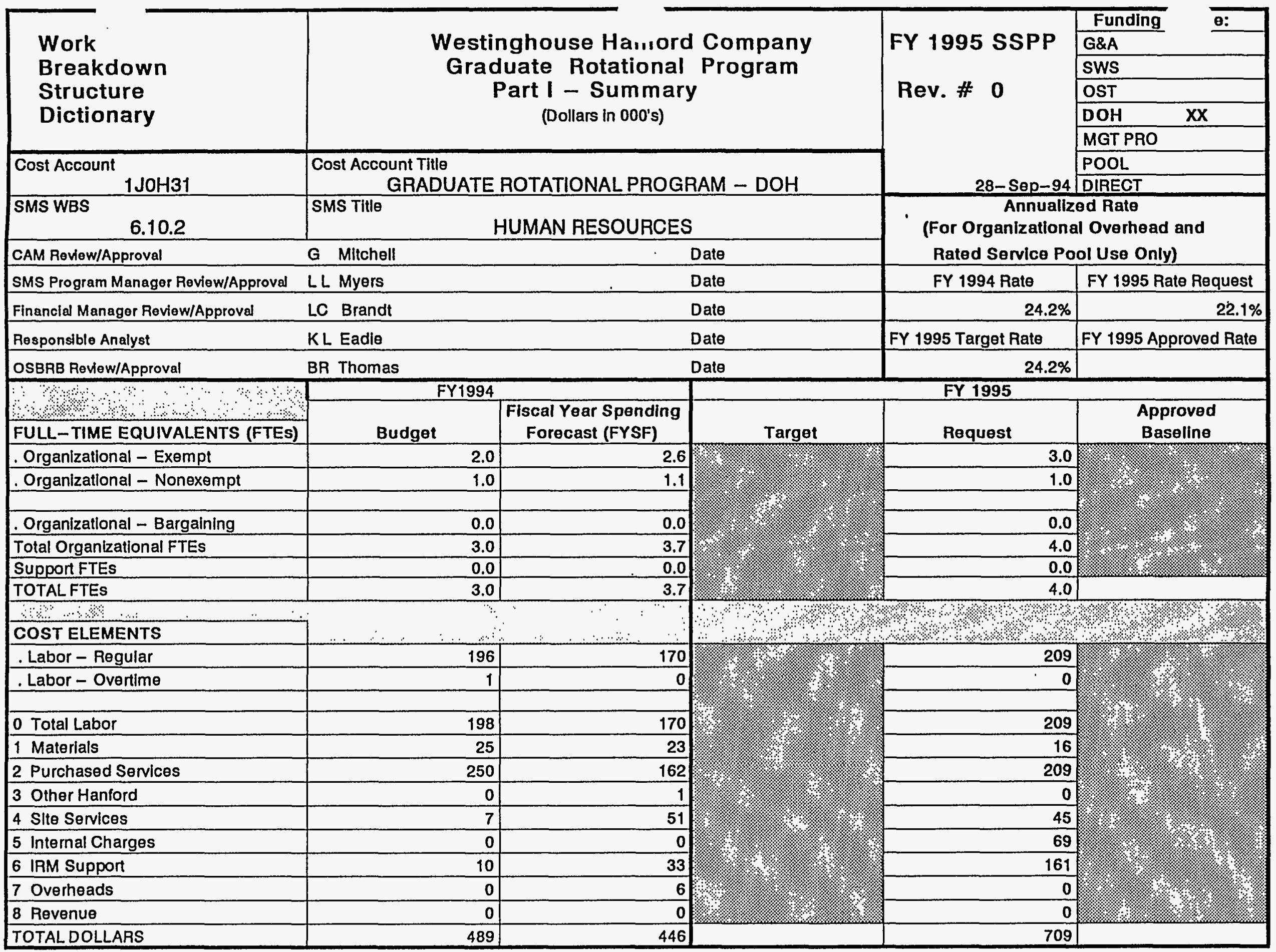




\begin{tabular}{|l|c|c|}
\hline \multicolumn{1}{|c|}{ COST ACcOUNT } & & \\
\hline $\begin{array}{l}\text { Work Breakdown } \\
\text { Structure } \\
\text { Dictionary }\end{array}$ & $\begin{array}{c}\text { Westinghouse Hanford Company } \\
\text { Graduate Rotational Program } \\
\text { Part II - Element Definition }\end{array}$ & Revision \# 0 \\
\hline
\end{tabular}

\begin{tabular}{|l|c|}
\hline WBS ELEMENT CODE: $\quad 6.10 .2$ & TITLE: GRADUATE ROTATIONAL PROGRAM - DOH \\
\hline $\begin{array}{l}\text { ELEMENT TASKDESCRIPTION } \\
\text { COST CONTENT - }\end{array}$
\end{tabular}

Department Overhead which is liquidated as a percentage added to the labor for the administratlve and technical employees In the Graduate Rotational Program.

\section{TECHNICAL CONTENT -}

To administer and manage the Graduate Rotatlonal program. This Involves a varlety of actlvilles such as the following:

1.) Development of the Job Rotatlon Process: Define the purpose and scope; Identify funding sources; set stafing requirements and program particlpatlon guldellnes; and the development, approval aquisition, then implementation of a program marketling strategy and implementatlon plan.

2.) Manage customer issues \& requests to effect results oriented resolution and tolal quality service: Customer service requires an immediate resonse crealing an impact on dally operalions requiling support staff to address customer questions, needs, and various lssues in a timely professional manner.

3.) Candldate Recrultment Selectlon \& Placement: Peglonal searches, supplemented by natlonal recrulting to address diversity lssues and obtaln highly quallied candidates. Selectlon Involves Interview trips, slte visils, as well as the assoclated administralive support. Placement is an ongoing communicatlon requirement to provide the numerous candidates with the opportunity for true developmental assignments to supply the WHC and DOE with maximum benefits.

4.) Design and Implement a development strategy that is participant driven: Counsel the particlpants and assist in the development of a strategy to incorporate near-term, mid-term, and long-term goals, objeclives, and needs of the WHC and the DOE with those of the employees.

\section{OBJECTIVES -}

To maximize the development of college graduate new hires, through short-term assignments In mulliple areas throughout the Haniord Site; thus providing the company with experlenced, knowledgeable, employees in an accelerated time frame, additionally allowing employees to gain a varlety of experiences relative to their fields of expertise to provlde a solld foundation for on the job decision making and outstanding pertormance.

\section{ASSUMPTIONS/CONSTRAINTS -}

Assessments were based on the organlzallonal billing tables and FY 1994 costs, and the other aspects were managerlal esilmates combining FY 1994 occurrances wilth the expectallons for 1995.

MILESTONES -

DOE-AL Millestone

FAH-95-012: Oral Presentatlon to describe the rofatlon process criterla for current employees to accelerate the broadening of skills for future Hanford actlvitles.

DELIVERABLES - 
Cost A Junt: 1J0H31

ELEMENT TASKDESCRIPTION: Graduate Rotational Program - DOH

\section{REQUESTS WITHIN TARGET:}

Activity Detalled Description

To administer and manage the Graduate Rotational Program which moves new hires through several different positions during the first two years of employment in order to provide a high level of personal, professional, and skill development to groom a more effeclive workforce. This activity includes all the operating costs to administer the program ranging from the routine assessments to customer service fulfilling the site's organizatlonal and employee specific needs.

$\star \star$ SIgnificant Budget increase due to accumulation of assessments fo rotationals budgeted in $\mathrm{DOH}$, particularly the IRM assessments. LABOR SUPPORT - (208.5K)

\section{Manager Grad Rotatlonal Program}

1 Exempt Specialist - Employee placements, rotational process development \& administration, design \& implementation of individual development strategies, provide customer service 1 Exempt admin. rotatlonal to assist where needed

1 Clerk/Secretary - Maintain flles and employee data and direct customer inquiries, and provide regular clerical support MATERIALS

Office supplies $(5.0 \mathrm{~K})$ \& Computer supplles $(8.0 \mathrm{~K})$ PURCHASE SERVICES

Onsite/Offsite Training (25.0K)

Educational Reimbursement (25.0)

Relocations (100.0K) \& Travel (35.0K)

Local Meetings/Conferences $(2.5 \mathrm{~K})$

PO Contracts $(20.0 \mathrm{~K})$

SITE SERVICES

MPR applied to purchases calculated at $11.3 \%$ (4.1K)

Occupancy Assessment (12.5K)

Bus Operallons \& Taxi Assessment (24.8K)

Safety Training for BBST (2.5K)

OTHER INTERNAL CHARGES

Dosimetry based on FY'94 costs w/o escalation (69.3K)

INFORMATIONS RESOURCE MANAGEMENT

Multimedia services for duplicating (15.0K)

Network Access (50.4K) \& Telephones (92.4K)

REQUESTS ABOVE TARGET:

Labor Cost

Non-Labor Cost

Total Cost Account: 1JOH31

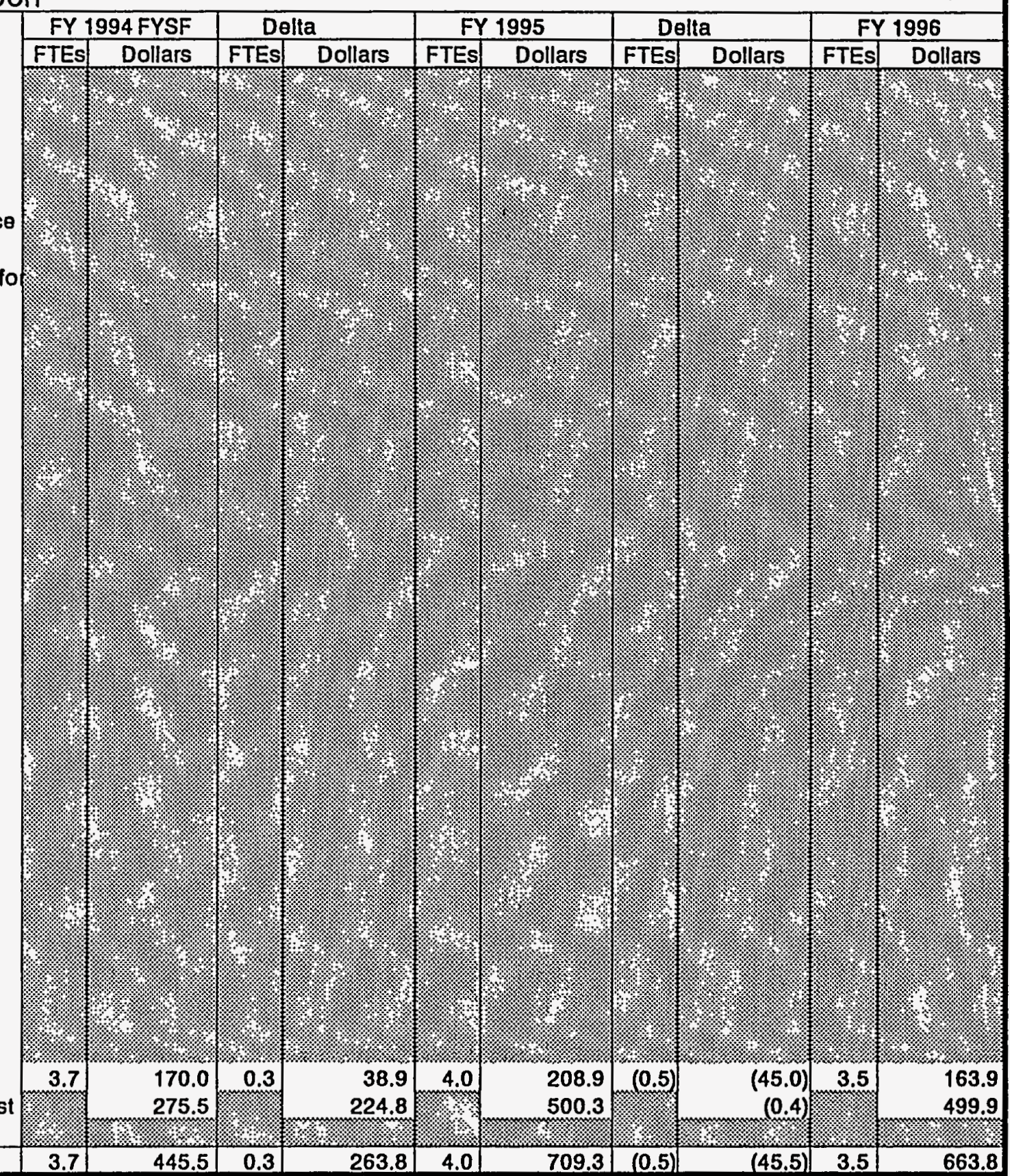




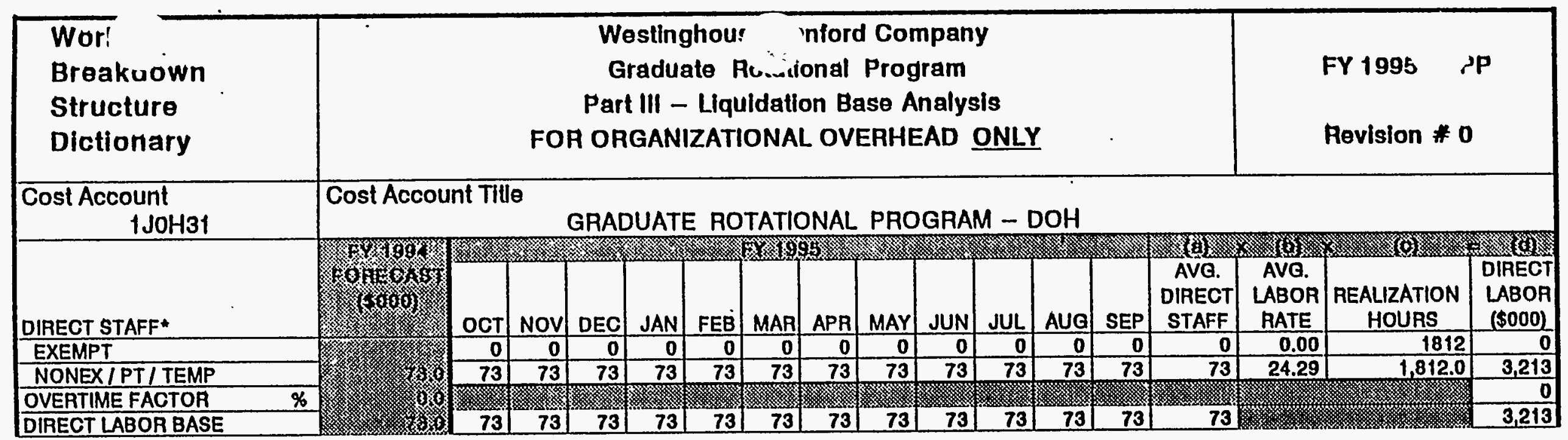

\begin{tabular}{|c|r|r|}
\hline ORG OVHD COST & 446 \\
\hline DIRECT LABOR BASE & 2,160 \\
\hline RATE (COST/BASE) & $20.6 \%$ & 3,213 \\
\hline
\end{tabular}

* Direct stan is staft that charges labor to charge codes on which organtzational overhead is applled.

\begin{tabular}{|c|c|c|c|c|c|c|c|}
\hline \multirow[b]{2}{*}{ Org } & \multicolumn{2}{|c|}{ \#* } & \multirow{2}{*}{$\begin{array}{l}\text { Effectlve \# } \\
\text { Employees }\end{array}$} & \multirow{2}{*}{\multicolumn{3}{|c|}{$\begin{array}{l}\text { Lbr rate Effectlve } \\
\text { Rate welght Rate }\end{array}$}} & \multirow{2}{*}{$\begin{array}{l}\text { Direct } \\
\text { Labor }\end{array}$} \\
\hline & Employess & Uillization \% & & & & & \\
\hline 4111 & 20.0 & $100 \%$ & 20.0 & 21.47 & 0.3 & 5.9 & 778 \\
\hline 41112 & $\underline{53.0}$ & $100 \%$ & $\underline{53.0}$ & 25.35 & $\underline{0.7}$ & 18.4 & 2435 \\
\hline TOTAL & 73.0 & $100 \%$ & 73.0 & & 1.00 & 24.29 & 3213 \\
\hline
\end{tabular}

** Employee utllization based on July 1994 fulltime equlvalent levels v.s. headcount levels per organizatlon - Headcount approval for 80 


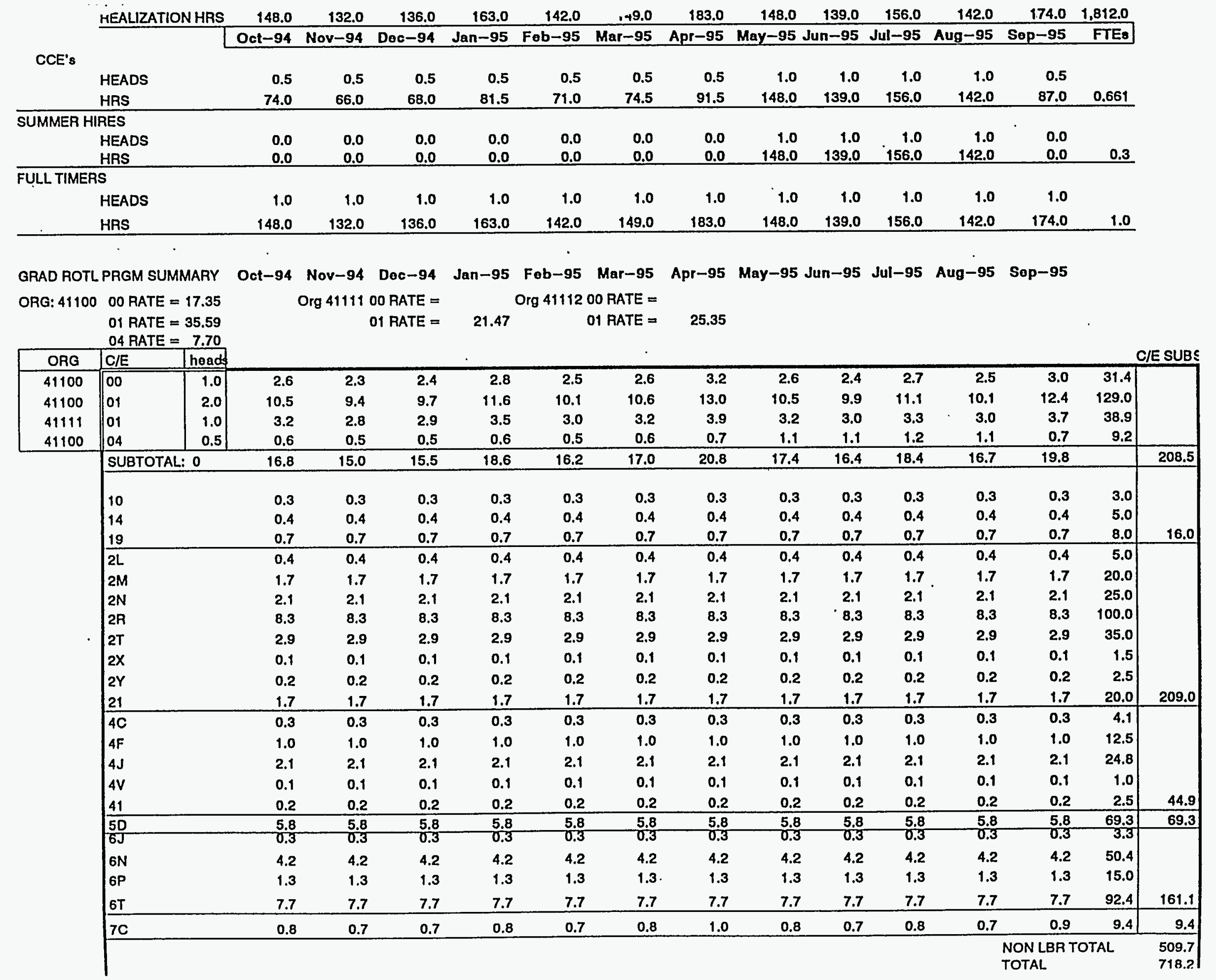




\begin{tabular}{|c|c|c|c|c|c|}
\hline \multirow{5}{*}{$\begin{array}{l}\text { Work } \\
\text { Breakdown } \\
\text { Structure } \\
\text { Dictionary }\end{array}$} & \multirow{5}{*}{\multicolumn{3}{|c|}{$\begin{array}{c}\text { Westinghouse Haniurd Company } \\
\text { Administrative Services } \\
\text { Part I - Summary } \\
\text { (Dollars in 000's) }\end{array}$}} & \multirow{6}{*}{$\begin{array}{l}\text { FY } 1995 \text { SSPP } \\
\text { Rev. \# } 0\end{array}$} & \multirow{4}{*}{\begin{tabular}{|l|} 
Funding \\
G\&A \\
SWS \\
OST \\
\end{tabular}} \\
\hline & & & & & \\
\hline & & & & & \\
\hline & & & & & \\
\hline & & & & & \begin{tabular}{|l|} 
OST \\
DOH
\end{tabular} \\
\hline Cost Account & \multirow{2}{*}{\multicolumn{3}{|c|}{$\begin{array}{l}\text { Cost Account THle } \\
\text { ADMINISTRATIVE SERVICES - DOH }\end{array}$}} & & $\overline{\mathrm{POOL}}$ \\
\hline $1 \mathrm{JOH} 16$ & & & & & \\
\hline 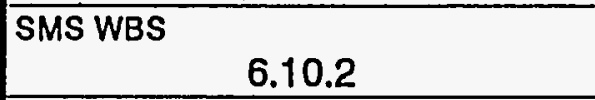 & \multicolumn{3}{|c|}{\begin{tabular}{|l} 
SMS TIlle \\
HUMAN RESOURCES
\end{tabular}} & \multirow{2}{*}{\multicolumn{2}{|c|}{$\begin{array}{c}\text { Annualized Rate } \\
\text { (For Organizational Overhead and } \\
\text { Rated Service Pool Use Only) }\end{array}$}} \\
\hline CAM Roview/Approval & DM Millbauer & \multicolumn{2}{|r|}{ Date } & & \\
\hline SMS Program Manager Reviow/Approval & LL Myers & \multicolumn{2}{|r|}{ Date } & FY 1994 Rate & \\
\hline Financial Managor Revlew/Approval & LC Brandt & \multicolumn{2}{|r|}{ Date } & $9.2 \%$ & \begin{tabular}{r|r} 
FY 1995 Rate Request \\
$13.5 \%$ \\
\end{tabular} \\
\hline Rosponsible Analyst & KL Eadie & \multicolumn{2}{|r|}{ Date } & FY 1995 Target Rate & FY 1995 Approved Rate \\
\hline OSBRB Reviow/Approval & BR Thomas & \multicolumn{2}{|r|}{ Date } & $9.2 \%$ & Fr ligso approved Rate \\
\hline 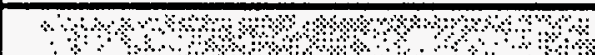 & \multicolumn{2}{|c|}{ FY1994 } & \multirow[t]{2}{*}{ FY 1995} & \multirow[t]{2}{*}{ FY 1995} & \multirow[b]{2}{*}{$\begin{array}{c}\text { Approved } \\
\text { Baseline }\end{array}$} \\
\hline$\frac{\text { ০০২ }}{\text { FULL-TIME EQUIVALENTS (FTES) }}$ & Budget & $\begin{array}{c}\text { Fiscal Year Spending } \\
\text { Forecast (FYSF) }\end{array}$ & & & \\
\hline Organlzational - Exempt & 2 & 1.6 & & 2 & \\
\hline . Organizational - Nonexempt & 1 & 2 & t) & 1 & \\
\hline Organizational - Bargaining & 0 & 0 & & 0 & \\
\hline Total Organizational FTEs & 3 & 3.6 & & 3 & \\
\hline Support FTEs & 0 & 1.5 & & 0.5 & \\
\hline TOTALFTES & 3 & 5.1 & & 3.5 & \\
\hline $\begin{array}{ll} \\
\text { COST ELEMENTS }\end{array}$ & b : & ?. & & ४ै। ४ै & \\
\hline . Labor - Regular & 129 & 199 & & 160 & \\
\hline . Labor - Overtime & & 1 & & & \\
\hline 0 Total Labor & 129 & 200 & & 160 & \\
\hline 1 Materials & 3 & 4 & & 6 & \\
\hline 2 Purchased Services & 5 & 2 & & 4 & \\
\hline 3 Other Hanford & $\mathbf{0}$ & $\underline{0}$ & & 0 & \\
\hline 4 Site Senvices & 7 & 53 & & 60 & \\
\hline 5 Internal Charges & 161 & 158 & & 176 & \\
\hline 6 IRM Support & 34 & 134 & & 239 & \\
\hline 7 Overheads & $\underline{0}$ & 1 & & 0 & \\
\hline 8 Revenue & $\underline{0}$ & 0 & & 0 & \\
\hline TOTALDOLLARS & 339 & 551 & & 645 & \\
\hline
\end{tabular}




\begin{tabular}{|c|c|c|}
\hline $\begin{array}{c}\text { H16 } \\
\text { COST ACCOUNT }\end{array}$ & & \\
\hline $\begin{array}{l}\text { Work Breakdown } \\
\text { Structure } \\
\text { Dictionary }\end{array}$ & $\begin{array}{c}\text { Westinghouse Hanford Company } \\
\text { Administrative Services } \\
\text { Part II - Element Definition }\end{array}$ & $\begin{array}{l}\text { FY } 1995 \text { SSPP } \\
\text { Revision \# } 0\end{array}$ \\
\hline
\end{tabular}

\begin{tabular}{|l|l|l|}
\hline WBS ELEMENT CODE: $\quad 6.10 .2$ & TITLE: & ADMINISTRATIVE SERVICES - DOH \\
\hline $\begin{array}{l}\text { ELEMENT TASKDESCRIPTION } \\
\text { COST CONTENT - }\end{array}$ & \\
\hline
\end{tabular}

Department Overhead which is llquldated as a percentage added to the labor for the $48^{*}$ organizations.

\section{TECHNICAL CONTENT -}

Adminlstrate the "Hourly Support Staff" with speclallzed clerical, secretarlal, professlonal, escort, and tour gulde knowledge and support useful to WHC, BCSR, DOE, and KEH In responding to peak work loads and epecialized program needs.

\section{OBJECTIVES -}

To be able to support managers throughout the Hanford slle In sltuations such as the following: maternity leaves, disability leaves, speclal staffing needs, vacatlons, escort support, tour guldes, and experllse knowledge of the Hanford Project.

\section{ASSUMPTIONS/CONSTRAINTS -}

As per DOE-RL recommendation to dlsconilinue usage of temporary services such as Kelly by the end of flscal year 1994, and replace with WHC Hourly Support Staft.

\section{MILESTONES -}

N/A

\section{DELIVERABLES -}

Administrallive Services does not have dellverebles but does support the slte with the following listed services: clerical, secretarial, professional, escort, and tour guide services. 
Cost A Junt: 1 JOH16

Pari - Element Definition (continued)

ELEMENT TASKDESCRIPTION: ADMINISTRATIVE SERVICES - DOH

\section{WORK STATEMENT -}

REQUESTS WITHIN TARGET:

\section{Actlvity Detalled Descriptlon}

To administer the Adminlstrative Services program which provides hourly support consisting of clerlcal, secretarial, professional, escort, and tour gulde services to the organizations throughout the Hanford sile providing temporary labor for matemity leaves, disability leaves, speclal stafiling needs, vacalions, escort support, and tour gulde assistance to offer expertise knowledge of the Hanford Project.

\section{LABOR SUPPORT - (159.3K)}

1 Manager Administrative Services

1 Exempt Speclalist - work with WHC managers to assign, rotate, train, and orient Hourly and Admin Revlew employees 1 Clerk/Secretary - Malntain flles and employee data and answer customer inquirles.

\section{MATERIALS}

Offlce supplles $(6.0 \mathrm{~K})$

\section{SITE SEAVICES}

MPR applled to purchases calculated at $11.3 \%(0.7 \mathrm{~K})$

Occupancy Assessment (15.3h)

Bus Operatlons \& Texl Assessment (18.1K)

Safoty Tralning for BBST (26.0K)

Assessments based on FY'94 cosls

OTHEA INTERNAL CHARGES

DosImetry based on FY'94 cosis w/o escalation (176.4K)

INFORIMATIONS RESOURCE MANAGEMENT

Multimedla servlces for dupllcating (3.6K)

Network Access Assessment (55.5K)

Telephone Assessment (180.0K)

Assessments based on FY' 94 costs

OVERHEADS \& ADJUSTMENTS

Overhead applled to temporary support esimated at $9.2 \%(0.6 \mathrm{~h})$

REQUESTS ABOVE TARGET:

Labor Cost Non-Labor Cost

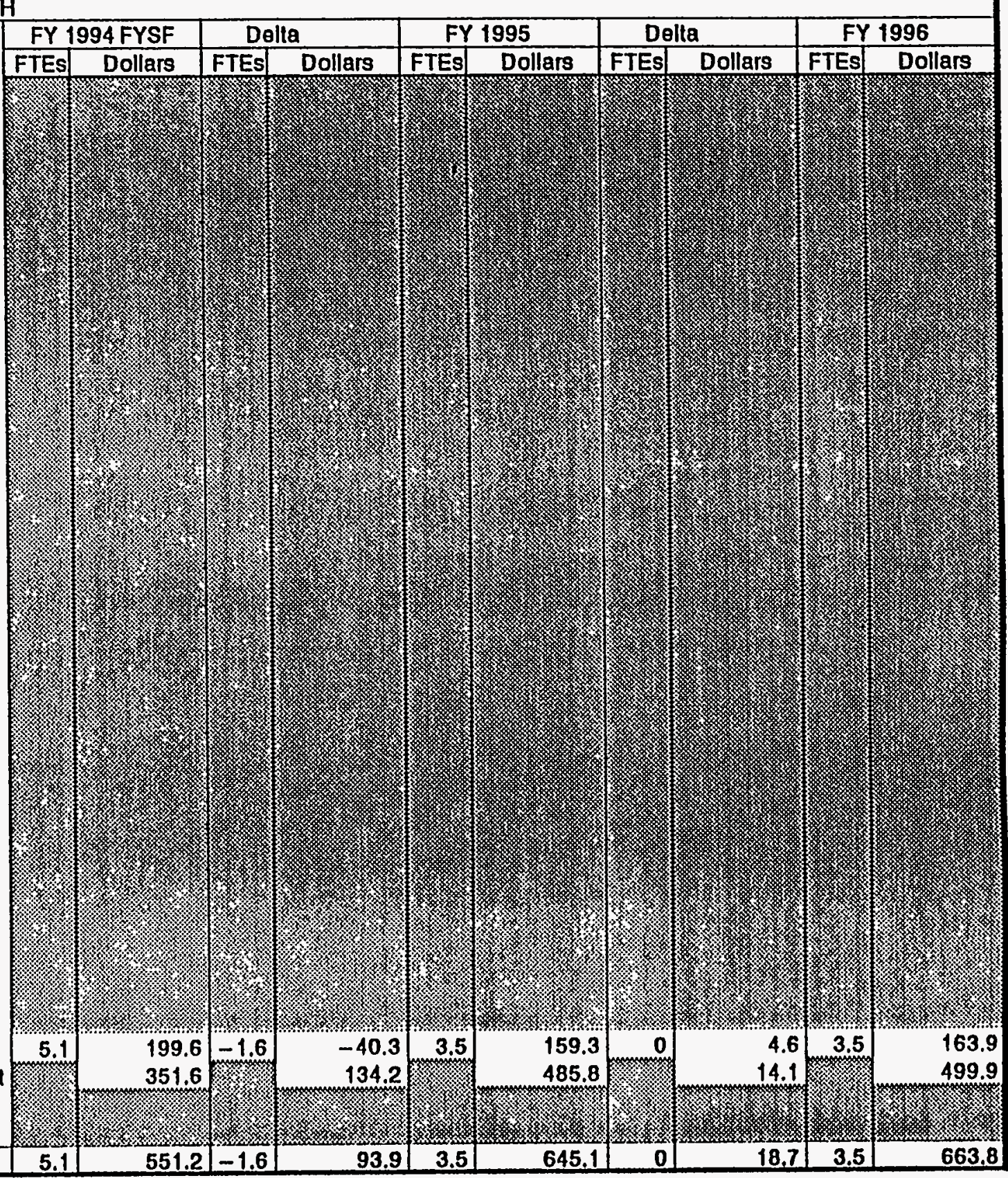

Tolal Cost Account: 1 JOH16 I

Costaccount $1 \mathrm{JOH}$




\begin{tabular}{|c|c|c|c|c|c|c|c|c|c|c|c|c|c|c|c|c|c|}
\hline $\begin{array}{l}\text { Work } \\
\text { Breakdown } \\
\text { Structure } \\
\text { Dictionary }\end{array}$ & \multicolumn{14}{|c|}{$\begin{array}{l}\text { Westinghouse ord Company } \\
\text { Administrative Services } \\
\text { Parț III - Liquidation Base Analysis } \\
\text { ORGANIZATIONAL OVERHEAD ONLY }\end{array}$} & \multicolumn{3}{|c|}{$\begin{array}{l}\text { FY } 1995 \text { SSPP } \\
\text { Revision \#0 }\end{array}$} \\
\hline $\begin{array}{c}\text { Cost Account } \\
\text { 1 J0H16 }\end{array}$ & ist Accou & Title & & ADMII & NISTF & RATIV & $E S E$ & AVIC & ES - & $\mathrm{DOH}$ & & 1 & & & & & \\
\hline DIRECT STAFF* & 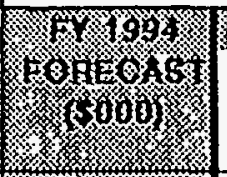 & $\mathrm{OCT}$ & Nov & DEC & JAN & FEB & MAR & APA & MAY & JUN & JUL & $A \cup G$ & SEP & $\begin{array}{l}\text { AVG. } \\
\text { DIRECT } \\
\text { STAFF } \\
\end{array}$ & $\begin{array}{l}\text { AVG. } \\
\text { LABOR } \\
\text { RATE } \\
\end{array}$ & $\begin{array}{c}\text { REALIZATION } \\
\text { HOURS }\end{array}$ & $\begin{array}{l}\text { DIRECT } \\
\text { LABOR } \\
(\$ 000) \\
\end{array}$ \\
\hline EXEMPT & 促 & 0 & 0 & 0 & 0 & 0 & 0 & 0 & 0 & 0 & 0. & 0 & of & 0 & 0.00 & 1812 & 0 \\
\hline NONEX/PT/TEMP & 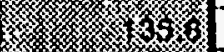 & 136 & 136 & 136 & 136 & 136 & 136 & 136 & 136 & 136 & 136 & 136 & 136 & 136 & 19.48 & 1812 & 4,787 \\
\hline $\begin{array}{l}\text { OVERTIME FACTOR } \\
\text { DIRECT LABOR BASE } \\
\end{array}$ & 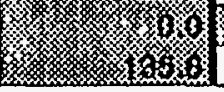 & 136 & 136 & 136 & 136 & 136 & 136 & 136 & 136 & 136 & 136 & 136 & 136 & 136 & & & $\begin{array}{r}0 \\
4,787 \\
\end{array}$ \\
\hline \begin{tabular}{|c|} 
OAQ OVHD COST \\
DIRECT LABOR BASE \\
RATE (COST/BASE) \\
\end{tabular} & \begin{tabular}{r|}
551 \\
3,689 \\
$14.9 \%$ \\
\end{tabular} & & & & & & & & & & & & & & & & $\begin{array}{r}645 \\
4,787 \\
13.5 \% \\
\end{array}$ \\
\hline
\end{tabular}

* Direct staff is staff that charges labor to charge codes on which organizallonal overhead is applied.

\begin{tabular}{|c|c|c|c|c|c|c|c|}
\hline \multirow[b]{2}{*}{ Org } & \multicolumn{2}{|c|}{ ^* } & \multirow{2}{*}{$\begin{array}{l}\text { Effectlve \# } \\
\text { Employees }\end{array}$} & Lbr & \multicolumn{2}{|c|}{ rate EHecilive } & \multirow{2}{*}{$\begin{array}{l}\text { Direct } \\
\text { Labor }\end{array}$} \\
\hline & Employeos & Utillzation $\%$ & & Rate & wolgh & 11 Rate & \\
\hline 48000 & 0 & $0 \%$ & $\begin{array}{l}\mathbf{0} \\
\end{array}$ & 0.00 & o & $\mathbf{0}$ & $\mathbf{0}$ \\
\hline 48002 & 1 & $100 \%$ & 1 & 24.31 & 0.01 & 0.18 & 44 \\
\hline 48003 & 80 & $77 \%$ & 61.5 & 13.31 & 0.45 & 6.04 & 1483 \\
\hline 48004 & 9 & $36 \%$ & 3.2 & 13.31 & 0.02 & 0.31 & 77.2 \\
\hline 48005 & 136 & $40 \%$ & 54.5 & 28.47 & 0.4 & 11.4 & 2812 \\
\hline 48006 & 15 & $20 \%$ & 3 & 13.31 & 0.02 & 0.29 & 72.4 \\
\hline 48007 & 12 & $103 \%$ & 12.4 & 13.31 & $\underline{0.09}$ & 1.22 & $\underline{299}$ \\
\hline TOTAL & 253 & $54 \%$ & $\overline{136}$ & & $\overline{1.00}$ & 19.48 & $4 \overline{787}$ \\
\hline
\end{tabular}

** Employee utllization based on July 1994 employment levels v.s. headcount levels per organizatlon 


\begin{tabular}{|c|c|c|c|c|c|c|c|c|c|c|c|c|c|c|c|}
\hline & MEAUZATION HOU & 148.0 & 1320 & 136.0 & 163.0 & 142.6 & 149.0 & $\begin{array}{r}183.0 \\
105\end{array}$ & 148.0 & $\begin{array}{r}139.0 \\
\end{array}$ & $\begin{array}{r}156.0 \\
\end{array}$ & 142.0 & $\begin{array}{r}174.0 \\
\operatorname{con}-05\end{array}$ & 1.20 & \\
\hline & & Oct-94 & Nov-94 & Dec-94 & Jan-95 & Feb-95 & Mar-95 & Apr-95 & May-95 & Jun-95 & Jul-95 & Aug-95 & & & \\
\hline \multicolumn{16}{|l|}{ CCE's } \\
\hline & HEADS & 0.5 & 0.5 & 0.5 & 0.5 & 0.5 & 0.5 & 0.5 & 1.0 & 1.0 & 1.0 & 1.0 & 0.5 & & \\
\hline & HAS & 74.0 & 66.0 & 68.0 & 81.5 & 71.0 & 74.5 & 91.5 & 148.0 & 139.0 & 156.0 & 142.0 & 87.0 & 0.7 & \\
\hline \multicolumn{16}{|c|}{ SUMMER HIRES } \\
\hline & $\begin{array}{l}\text { HEADS } \\
\text { HRS }\end{array}$ & $\begin{array}{l}0.0 \\
0.0\end{array}$ & $\begin{array}{l}0.0 \\
0.0\end{array}$ & $\begin{array}{l}0.0 \\
0.0\end{array}$ & $\begin{array}{l}0.0 \\
0.0\end{array}$ & $\begin{array}{l}0.0 \\
0.0\end{array}$ & $\begin{array}{l}0.0 \\
0.0\end{array}$ & $\begin{array}{l}0.0 \\
0.0\end{array}$ & $\begin{array}{r}1.0 \\
148.0 \\
\end{array}$ & $\begin{array}{r}1.0 \\
139.0 \\
\end{array}$ & $\begin{array}{r}1.0 \\
156.0 \\
\end{array}$ & $\begin{array}{r}1.0 \\
142.0 \\
\end{array}$ & $\begin{array}{l}0.0 \\
0.0\end{array}$ & 0.3 & \\
\hline \multicolumn{16}{|c|}{ FULL TIMERS } \\
\hline & HEADS & 1.0 & 1.0 & 1.0 & 1.0 & 1.0 & 1.0 & 1.0 & 1.0 & 1.0 & 1.0 & 1.0 & 1.0 & & \\
\hline & HRS & 148.0 & 132.0 & 136.0 & 163.0 & 142.0 & 149.0 & 183.0 & 148.0 & 139.0 & 156.0 & 142.0 & 174.0 & 1.0 & \\
\hline \multicolumn{2}{|c|}{ ADMIN SERV - - SUMMARY } & Oct-94 & Nov-94 & Dec-94 & Jan-95 & Fob-95 & Mar-95 & Apr-95 & May-95 & Jun-95 & Jul-95 & Aug-95 & Sep-95 & & \\
\hline ORG: 46330 & 00 RATE $=16.75$ & & & & & & & & & & & & & & \\
\hline & $\begin{array}{l}01 \text { RAT } \\
04 \text { RAT }\end{array}$ & & & & & & & & & & & & & & \\
\hline & FTE & & & & & & & & & & & & & & IE SUBS \\
\hline & 1.0 & 2.5 & 2.2 & 2.3 & 2.7 & 2.4 & 2.5 & 3.1 & 2.5 & 2.3 & 2.6 & 2.4 & 2.9 & 30.4 & \\
\hline & 2.0 & 10.0 & 8.9 & 9.2 & 11.0 & 9.6 & 10.0 & 12.3 & 10.0 & 9.4 & 10.5 & 9.6 & 11.7 & 122.0 & \\
\hline & 0.5 & 0.6 & 0.5 & 0.5 & 0.6 & 0.5 & 0.6 & 0.7 & 0.6 & 0.5 & 0.6 & 0.5 & 0.7 & 7.0 & \\
\hline \multicolumn{2}{|r|}{ SUBTOTAL: 0} & 13.0 & 11.6 & 12.0 & 14.3 & 12.5 & 13.1 & 16.1 & 13.0 & 12.2 & 13.7 & 12.5 & 15.3 & & 159.3 \\
\hline & 14 & 0.5 & 0.5 & 0.5 & 0.5 & 0.5 & 0.5 & 0.5 & 0.5 & 0.5 & 0.5 & 0.5 & 0.5 & 6.0 & 6.0 \\
\hline & $2 \mathrm{~L}$ & 0.3 & 0.3 & 0.3 & 0.3 & 0.3 & 0.3 & 0.3 & 0.3 & 0.3 & 0.3 & 0.3 & $0.3^{-}$ & 3.6 & 3.6 \\
\hline & $4 C$ & 0.1 & 0.1 & 0.1 & 0.1 & 0.1 & 0.1 & 0.1 & 0.1 & 0.1 & 0.1 & 0.1 & 0.1 & 0.7 & \\
\hline & $4 F$ & 1.3 & 1.3 & 1.3 & 1.3 & .1 .3 & 1.3 & 1.3 & 1.3 & 1.3 & 1.3 & 1.3 & 1.3 & 15.3 & \\
\hline & $4 \mathrm{~J}$ & 1.5 & 1.5 & 1.5 & 1.5 & 1.5 & 1.5 & 1.5 & 1.5 & 1.5 & 1.5 & 1.5 & 1.5 & 18.1 & \\
\hline & 41 & 2.2 & 2.2 & 2.2 & 2.2 & 2.2 & 2.2 & 2.2 & 2.2 & 2.2 & 2.2 & 2.2 & 2.2 & 26.0 & 60.1 \\
\hline & $5 \mathrm{D}$ & 14.7 & 14.7 & 14.7 & 14.7 & 14.7 & 14.7 & 14.7 & 14.7 & 14.7 & 14.7 & 14.7 & 14.7 & 176.4 & 176.4 \\
\hline & $6 N$ & 4.6 & 4.6 & 4.6 & 4.6 & 4.6 & 4.6 & 4.6 & 4.6 & 4.6 & 4.6 & 4.6 & 4.6 & 55.5 & \\
\hline & GP & 0.3 & 0.3 & 0.3 & 0.3 & 0.3 & 0.3 & 0.3 & 0.3 & 0.3 & 0.3 & 0.3 & 0.3 & 3.6 & \\
\hline & $6 T$ & 15.0 & 15.0 & 15.0 & 15.0 & 15.0 & 15.0 & 15.0 & 15.0 & 15.0 & 15.0 & 15.0 & 15.0 & 180.0 & 239.1 \\
\hline & $7 C$ & 0.1 & 0.0 & 0.0 & 0.1 & 0.1 & 0.1 & 0.1 & 0.1 & 0.0 & 0.1 & 0.1 & 0.1 & 0.6 & 0.6 \\
\hline & & & & & & & & & & & & \multicolumn{3}{|c|}{$\begin{array}{l}\text { NON LBR TOTAL } \\
\text { TOTAL }\end{array}$} & $\begin{array}{r}485.8 \\
645.1\end{array}$ \\
\hline
\end{tabular}




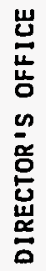




\begin{tabular}{|c|c|c|}
\hline 1.A Vision/Mission & $\begin{array}{c}\text { Westinghouse Hanford Company } \\
\text { Directors Office } \\
\text { SMS/WBS No. } 6.10 .2 \\
\end{array}$ & $\begin{array}{c}\text { FY } 1995 \\
\text { Site Support Program P1an } \\
\text { Date Prepared: } \quad 8 / 12 / 94\end{array}$ \\
\hline
\end{tabular}

\section{PROCESSES AND PLANNING 6.10 .2 .6}

The primary purpose of the Human Resources (HR) Processes and Planning organization is to provide the customer, Department of Energy, Richland Operations Office (RL), Westinghouse Hanford Company (WHC), BCS Richland, Inc. (BCSR) and ICF Kaiser Hanford Company (ICF KH) a central point of contact for HR planning and reporting.

\section{HR STRATEGIC INITIATIVES $\quad 6.10 .2 .7$}

Develops and assists in implementing vital longer term HR strategies, programs, projects and practices. Collaborates on and/or develops HR strategic planning initiatives having Company-wide application.

\section{HR TRANSFORMATION OPERATIONS $\quad 6.10 .2 .5$}

Initiates management development programs, activities and communications for senior level executives and their staffs. Provides direct management of outsourced teambuilding and organizational development contracts. Ensures that productivity improvement initiatives and cost reduction programs are implemented within the Human Resources function. Implements "lessons learned" from other locations at Hanford and across the Corporation. 


\section{B.1 Internal Assessment Summary}

Westinghouse Hanford Company

Directors Office SMS/WBS No. 6.10.2

FY 1995

Site Support Program Plan

Date Prepared: 8/12/94

\section{PRIMARY CUSTOMERS}

The RL HR Division

WHC/BCSR/ICF KH Programs and Projects

Westinghouse Electric Corporation

\section{PRODUCTS/SERVICES PROVIDED}

- Site Support Program Plan,

- Staffing Plan development,

- Site Management System Reporting,

- Management Review Board Actions,

- Resolution of HR employee concerns issues,

- Development of HR Strategic PTan,

- Development of Management Development programs,

- Management of outsourced teambuilding and organizational development contracts,

- Lessons learned implementation at Hanford from other Westinghouse locations, and

- Point of Contact (POC) for HR budget development. 


\section{B.1 Internal Assessment Summary}

Westinghouse Hanford Company Directors Office SMS/WBS No. 6.10.2
FY 1995

Site Support Program PIan

Date Prepared: $8 / 12 / 94$

\section{PRIMARY CUSTOMERS}

The RL HR Division

WHC/BCSR/ICF KH Programs and Projects

Westinghouse Electric Corporation

\section{PRODUCTS/SERVICES PROVIDED}

- Site Support Program P1an,

- Staffing Plan development,

- Site Management System Reporting,

- Management Review Board Actions,

- Resolution of HR employee concerns issues,

- Development of HR Strategic Plan,

- Development of Management Development programs,

- Management of outsourced teambuilding and organizational development contracts, and

- Lessons learned implementation at Hanford from other Westinghouse locations. 


\begin{tabular}{|l|c|c|}
\hline & Westinghouse Hanford Company & FY 1995 \\
Directors Office & SMS/WBS No. 6.10.2 & $\begin{array}{c}\text { Site Support Program PTan } \\
\text { Date Prepared: } 8 / 12 / 94\end{array}$ \\
\hline
\end{tabular}

\section{MAJOR ACTIVITIES PERFORMED TO DELIVER PRODUCTS AND SERVICES}

See Section 2.A.2

EVALUATION OF MAJOR ACTIVITIES (COST, VALUE-ADDED, ETC.)

Real value-added activity associated with a central organization providing a total Company oversight for HR policy interpretations, staffing trends and compliance with Company staffing ceilings.

\section{FACTORS WHICH INFLUENCE RESOURCE CONSUMPTION (CHANGES TO COST AND VOLUME)}

Influencing factors inciude outsourcing, downsizing, $3161 \mathrm{P} 1 \mathrm{an}$, external benefit changes, and rules and regulations establishing diversity goals.

\section{FACTORS THAT INFLUENCE CHANGES IN TYPES OR NATURE OF PRODUCTS and SERVICES}

Special requests and guidance from Department of Energy, RL and WHC management.

Changes in WHC program direction. 


\begin{tabular}{|c|c|c|}
\hline 1.B.2. External Assessment Summary & $\begin{array}{c}\text { Hestinghouse Hanford Company } \\
\text { Directors Office } \\
\text { SMS/WBS No.6.10.2 }\end{array}$ & $\begin{array}{c}\text { FY 1995 } \\
\text { Site Support Program P1an } \\
\text { Date Prepared: } 8 / 12 / 94\end{array}$ \\
\hline
\end{tabular}

\section{SUMMARY OF CUSTOMER REQUIREMENTS (NEEDS)}

Workforce staffing projections, as detailed in the WHC Staffing P1an, for utilization in the Workforce Transition Model.

\section{OTHER EXTERNAL CHALLENGES}

3161 (restructuring) 


\begin{tabular}{|l|c|c|}
\hline 1.C Goals and Objectives & $\begin{array}{c}\text { Festinghouse Hanford Company } \\
\text { Directors Office } \\
\text { SMS/WBS No. 6.10.2 }\end{array}$ & $\begin{array}{c}\text { Site Support Program Plan } \\
\text { Date Prepared: 8/12/94 }\end{array}$ \\
\hline
\end{tabular}

\section{GOALS}

Provide a central point of contact for our customers to address HR planning and reporting on Companywide programs, projects and practices.

Develop innovative, "out-of-the box," value-added strategies that help make the most effective use of a highly skilled, diverse, agile, responsive workforce to achieve business success.

\section{OBJECTIVES}

Evaluate opportunities for outsourcing work scope within HR.

Assess the necessity for and redundancy of multiple WHC/BCSR/ICF KH periodic reports on staffing levels vs. internat ceilings. 


\begin{tabular}{|c|c|c|}
\hline 1.D Strategies & $\begin{array}{l}\text { Westinghouse Hanford Company } \\
\text { Directors Office } \\
\text { SMS/WBS No. } 6.10 .2 \\
\end{array}$ & $\begin{array}{c}\text { FY } 1995 \\
\text { Site Support Program P1an } \\
\text { Date Prepared: } \quad 8 / 12 / 94 \\
\end{array}$ \\
\hline
\end{tabular}

\section{CUSTOMER SUPPORT STRATEGIES}

Development of the Site Support Program Plan (SSPP) for effective work force planning utilizing the Site Management System (SMS). Development of workforce staffing projections using the 88 job categories contained in the Common Occupational Classification System (COCS) for the first two years and the nine COCS job families for the following five years to support the Hanford Integrated Work Force Planning Process.

\section{PRODUCTION STRATEGIES}

Strategies are incorporated in the WHC HR Strategic Plan development. 


\begin{tabular}{|c|c|c|}
\hline 1.E Assumptions & $\begin{array}{l}\text { Westinghouse Hanford Company } \\
\text { Directors Office } \\
\text { SMS/WBS No. } 6.10 .2\end{array}$ & $\begin{array}{c}\text { FY } 1995 \\
\text { Site Support Program Plan } \\
\text { Date Prepared: } \quad 8 / 12 / 94 \\
\end{array}$ \\
\hline
\end{tabular}

\section{ASSUMPTIONS}

The development of the SSPP that links required HR with workscope to authorize and control staffing levels form the basis for development of the WHC/BCSR/ICF KH Staffing PIan. The Staffing PIan is to be delivered to RL six (6) weeks after RL approval of the SSPP. The scheduled delivery date of $11 / 15 / 94$ is based on the assumption of RL approval by 10/1/94. Should this approval be delayed, there will be a corresponding slippage in delivery of the Staffing Plan. 


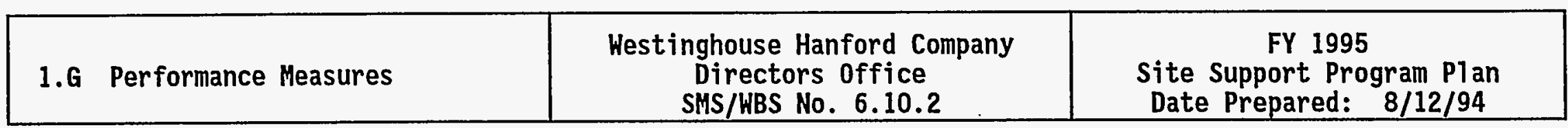

\section{PERFORMANCE MEASURES}

- $\quad$ Site Management System Review

- Monthiy. budget vs. actual reports

- Milestone Compliance

- $\quad$ Feedback from Organizations Supported 


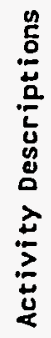

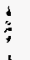

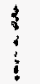

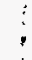

. in 


\begin{tabular}{|c|c|}
\hline 2.A.2 Description of Activities & $\begin{array}{l}\text { Westinghouse Hanford Company } \\
\text { Directors Office } \\
\text { SMS/HBS No. } 6.10 .2 \\
\end{array}$ \\
\hline ACTIVITY & DESCRIPTION \\
\hline \multirow{3}{*}{$\begin{array}{l}\text { Staffing Plan } \\
\text { (See Milestone Description Sheet } \\
\text { for resources) }\end{array}$} & Development of the WHC/BCSR/ICF-KH Staffing Plan \\
\hline & $\begin{array}{l}\text { Cross Support: } \\
\text { Support provided from the Human Resources Information Services } \\
\text { organization for development of the Staffing Plan and accessing the } \\
\text { payroll/personnel system for baseline compliance reports. Document } \\
\text { publication support from IRM for editing, word processing and } \\
\text { duplication services. }\end{array}$ \\
\hline & $\begin{array}{l}\text { Monitoring actual staffing levels, developing trends based on } \\
\text { analyses of hiring/attrition to determine compliance with approved } \\
\text { staffing levels. }\end{array}$ \\
\hline $\begin{array}{l}\text { Site Management System } \\
.1 \mathrm{M} \\
.6 \mathrm{Ex} \\
.5 \mathrm{Nx}\end{array}$ & $\begin{array}{l}\text { Compile data, develop reports and support reviews for the monthly } \\
\text { Site Management System meetings. }\end{array}$ \\
\hline $\begin{array}{l}\text { Site Support Program Plan } \\
\text { (See Milestone Description Sheet } \\
\text { for resources) }\end{array}$ & $\begin{array}{l}\text { Prepare the Human Resources Site Support Program Plan. } \\
\text { Report baseline compliance and, as required, utilize the formal } \\
\text { change control process to ensure baseline integrity. }\end{array}$ \\
\hline $\begin{array}{l}\text { Management Review Board } \\
.2 \mathrm{M} \\
.2 \mathrm{Nx}\end{array}$ & $\begin{array}{l}\text { As a member of the Management Review Board; assemble and review } \\
\text { Board actions, interface with organizations on candidate } \\
\text { qualifications, prepare agenda and attend a } 11 \text { meetings as Board } \\
\text { secretary. }\end{array}$ \\
\hline $\begin{array}{l}\text { Special Programs } \\
.5 \mathrm{M} \\
.2 \mathrm{Ex} \\
.3 \mathrm{Nx}\end{array}$ & $\begin{array}{l}\text { Administer special programs such as Technology Transfer Through } \\
\text { People, United Way Loaned Executive Program and the HR Employee } \\
\text { Concerns Program. }\end{array}$ \\
\hline
\end{tabular}




\begin{tabular}{|c|l|c|}
\hline \hline 2.A.2 Description of Activities & $\begin{array}{c}\text { Hestinghouse Hanford Company } \\
\text { Diretors office } \\
\text { SMS/HBS No. 6.10.2 }\end{array}$ & $\begin{array}{c}\text { FY 1995 } \\
\text { Site Support Program Plan } \\
\text { Date Prepared: 8/12/94 }\end{array}$ \\
\hline ACTIVITY & \multicolumn{1}{|c|}{ DESCRIPTION } \\
\hline $\begin{array}{c}\text { Administration Department's } \\
\text { Employee Concerns Program } \\
.1 \mathrm{M}\end{array}$ & $\begin{array}{l}\text { Human Resources and Administration Department's Employee Concerns } \\
\text { Coordinator including performing special studies, as needed. }\end{array}$ \\
\hline $\begin{array}{c}\text { Strategic Plan } \\
\text { (See Milestone Description Sheet } \\
\text { for resources) }\end{array}$ & $\begin{array}{l}\text { Development of the HR Strategic Plan to provide the basic structure } \\
\text { to lead Human Resources, and WHC, through the challenges of the } \\
\text { upcoming year. }\end{array}$ \\
\hline & \\
\hline & \\
\hline & \\
\hline & \\
\hline & \\
\hline & \\
\hline & \\
\hline & \\
\hline & \\
\hline & \\
\hline & \\
\hline & \\
\hline & \\
\hline & \\
\hline & \\
\hline & \\
\hline
\end{tabular}




\begin{tabular}{|c|c|c|c|c|c|c|c|c|}
\hline \multicolumn{4}{|c|}{ Ful1-Time Equivalent Staff by Job Description } & \multicolumn{5}{|c|}{ NOTE: Job Family Only After 1996} \\
\hline JOB FAMILY QPS & $\therefore$. & & & $\because \therefore$ & ! & का & ४४४। & Hیa \\
\hline Job category & 1994 & 1995 & 1996 & 1997 & 1998 & 1999 & 2000 & 2001 \\
\hline MANAGERS $: \because$ a & & & & $6: 0$ & $\because 6.0 .0$ & 3.0. & अ.0.: & 6.6 \\
\hline First line & & & & & & & & \\
\hline General/executive & & 6.0 & 6.0 & & & & & \\
\hline Project/Program & & & & & & & & \\
\hline other & & & & & & & & \\
\hline ENGINEERS : $: \cdots:$ & & & & & $\therefore \quad \therefore$ & +४। & ४४ & $\because \cdots$ \\
\hline Chemical & & & & & & & & \\
\hline Civil & & & & & & & & \\
\hline Computer & & & & & & & & \\
\hline Electrical & & & & & & & & \\
\hline Environmental & & & & & & & & \\
\hline Industrial & . & & & & & & & \\
\hline Mechanical & & & & & & & & \\
\hline Nuclear & & & & & & & & \\
\hline Petroleum/Mining & & & & & & & & \\
\hline Plant & & & & & & & & \\
\hline Quality Control & & & & & & & & \\
\hline Safety & & & & & & & & \\
\hline other & & & & & & & & \\
\hline SCIENTISTS & & & & & & & & \\
\hline
\end{tabular}




\begin{tabular}{|c|c|c|c|c|c|c|c|c|}
\hline \multicolumn{4}{|c|}{ Ful1-Time Equivalent Staff by Job Description } & \multicolumn{5}{|c|}{ NOTE: Job Family Only After 1996} \\
\hline JOB FAMHYP & & & & $\because \quad \cdots$ & खिए & अ०० & अै। & +: \\
\hline Job category & 1994 & 1995 & 1996 & 1997 & 1998 & 1999 & 2000 & 2001 \\
\hline Chemists & & & & & & & & \\
\hline Environmental & & & & & & & & \\
\hline Geologists & & & & & & & & \\
\hline Life & & & & & & & & \\
\hline Material & & & & & & & & \\
\hline Mathematicians & & & & & & & & \\
\hline Physicists & & & & & & & & \\
\hline Social & & & & & & & & \\
\hline other & & & & & & & & \\
\hline ADHYN/OTHER PROFESSIONALS & & $\therefore$ & 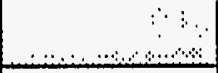 & $\therefore \quad 1.5$ & 1.5 & 10 & अ1.5 & +1: \\
\hline Accountant/audi tor & & & & & & & & \\
\hline Architect & & & & & & & & \\
\hline Buyers/procurement & & & & & & & & \\
\hline Communications & & & & & & & & \\
\hline Compliance inspectors & & & & & & & & \\
\hline Computer System Anal & & & & & & & & \\
\hline Cost Est/planner/sch & & & & & & & & \\
\hline Heal th Physics & & & & & & & & \\
\hline Industrial Hygiene & & & & & & & & \\
\hline Lawyers & & & & & & & & \\
\hline
\end{tabular}




\begin{tabular}{|c|c|c|c|c|c|c|c|c|}
\hline \multicolumn{4}{|c|}{ Full-Time Equivalent Staff by Job Description } & \multicolumn{5}{|c|}{ NOTE: Job Family Only After 1996} \\
\hline JÖB FAMMLY & : & . & $\because \quad 3$ & \begin{tabular}{|c|} 
\\
\end{tabular} & - & ina? & +ै: & बis: \\
\hline Job category & 1994 & 1995 & 1996 & 1997 & 1998 & 1999 & 2000 & 2001 \\
\hline Personnel/Labor Rela & & 1.5 & 1.5 & & - & & . & \\
\hline \multicolumn{9}{|l|}{ Physicians } \\
\hline \multicolumn{9}{|l|}{ Physician Assis/Nurs } \\
\hline \multicolumn{9}{|l|}{ Safeguard \& Security } \\
\hline \multicolumn{9}{|l|}{ Tech Writers \& Edit } \\
\hline \multicolumn{9}{|l|}{ Trainers } \\
\hline \multicolumn{9}{|l|}{ other } \\
\hline \multicolumn{9}{|c|}{ ওै। } \\
\hline \multicolumn{9}{|l|}{ Job category } \\
\hline GEN ADMM/SECRETARYYCLERK & & & & 2.5 & $2.5: 1$ & $3+5$ & 2.5 & 2.5 \\
\hline \multicolumn{9}{|l|}{ Admin Assistants } \\
\hline office Clerks (Gen) & & .5 & .5 & & & & & \\
\hline \multicolumn{9}{|l|}{ office Clerks (Special) } \\
\hline Secretaries & & 2.0 & 2.0 & & & & & \\
\hline \multicolumn{9}{|l|}{ Typist/Hord Process } \\
\hline \multicolumn{9}{|l|}{ other } \\
\hline \multicolumn{9}{|l|}{ TECHNICIANS } \\
\hline \multicolumn{9}{|l|}{ Computer Oper/Coder } \\
\hline \multicolumn{9}{|l|}{ Drafters } \\
\hline Engrs/Tech & & & & & & & & \\
\hline
\end{tabular}




\begin{tabular}{|c|c|c|c|c|c|c|c|c|}
\hline \multicolumn{4}{|c|}{ Fu11-Time Equivalent Staff by Job Description } & \multicolumn{5}{|c|}{ NOTE: Job Family Only After 1996} \\
\hline JoB FAMitLr & & & & is & अি & बि: & अै। & িि: \\
\hline Job category & 1994 & 1995 & 1996 & 1997 & 1998 & 1999 & 2000 & 2001 \\
\hline \multicolumn{9}{|l|}{ Envir. Sci Technicians } \\
\hline \multicolumn{9}{|l|}{ Heal th Phys. Technic. } \\
\hline \multicolumn{9}{|l|}{ Indus. Saf/Heal th Tech } \\
\hline \multicolumn{9}{|l|}{ Instru/Control Tech } \\
\hline \multicolumn{9}{|l|}{ Lab. Technicians } \\
\hline \multicolumn{9}{|l|}{ Media Technicians } \\
\hline \multicolumn{9}{|l|}{ Survey/Map Tech } \\
\hline \multicolumn{9}{|l|}{ other } \\
\hline \multicolumn{9}{|c|}{ s } \\
\hline \multicolumn{9}{|l|}{ Carpenters } \\
\hline \multicolumn{9}{|l|}{ Electricians } \\
\hline \multicolumn{9}{|l|}{ HVAC } \\
\hline \multicolumn{9}{|l|}{ Machinists } \\
\hline \multicolumn{9}{|l|}{ Masons } \\
\hline \multicolumn{9}{|l|}{ Millwrights } \\
\hline \multicolumn{9}{|l|}{ Painters } \\
\hline \multicolumn{9}{|l|}{ Plumbers/Pipefitters } \\
\hline \multicolumn{9}{|l|}{ Struct/Metal Horkers } \\
\hline \multicolumn{9}{|l|}{ Vehic./Mob Equip Mech } \\
\hline Welders & & & & & & & & \\
\hline
\end{tabular}




\begin{tabular}{|c|c|c|c|c|c|c|c|c|}
\hline \multicolumn{4}{|c|}{ Ful1-Time Equivalent Staff by Job Description } & \multicolumn{5}{|c|}{ NOTE: Job Family Only After 1996} \\
\hline SOB FAMLLY & $\because$ & & আ & अथ। & आ. & क्ष। & अ? & i: \\
\hline Job category & 1994 & 1995 & 1996 & 1997 & 1998 & 1999 & 2000 & 2001 \\
\hline other & & & & & & & & \\
\hline 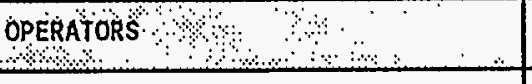 & & & $\because \quad \vdots \quad \vdots$ & 3. & - & के? & ४ै: & +ि: \\
\hline Chemical System & & & & & & & & \\
\hline Drillers & & & & & & & & \\
\hline Lt. Vehicle Drivers & & & & & & & & \\
\hline Material Moving Equip & & & & & & & & \\
\hline Nuclear Plant & & & & & & & & \\
\hline Utilities Waste Proces & & & & & & & & \\
\hline Other & & & & & & & & \\
\hline LABOR \& GEN WORKKERS & & & & & 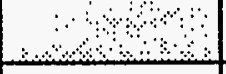 & अ & : & @ि: \\
\hline Firefighters & & & & & & & & \\
\hline Food Service & & & & & & & & \\
\hline Hand/Help Lab Gen & & & & & & & & \\
\hline Hand/Help Lab Spec & & & & & & & & \\
\hline Janitors/Cleaners & & & & & & & & \\
\hline Laundry Horkers & & & & & & & & \\
\hline Security Guards & & & & & & & & \\
\hline other & & & & & & & & \\
\hline & * 3.2 & 10.0 & 10.0 & 10.0 & 10.0 & 10.0 & 10.0 & 10.0 \\
\hline
\end{tabular}

* Approved 1994 Fiscal Year Work Plan 


\begin{tabular}{|c|c|c|c|}
\hline \multicolumn{3}{|c|}{ Site Support Program Plan } & $\begin{array}{l}\text { Date: } \\
\quad 09 / 23 / 94\end{array}$ \\
\hline \multicolumn{3}{|l|}{$\begin{array}{l}\text { Assigned To: } \\
\text { J. H. Hammond } \\
\end{array}$} & CIN: \\
\hline \multicolumn{3}{|c|}{$\begin{array}{l}\text { Program WBS Designator: } \\
6.10 .2 .6\end{array}$} & $\begin{array}{l}\text { Due Date: } \\
8 / 31 / 95 \\
\end{array}$ \\
\hline \multicolumn{3}{|c|}{ Control Number: FAH-95-017 } & Rev.: \\
\hline $\begin{array}{l}\text { MILESTONE TYPE: } \\
\square \text { DOE-HQ } \\
\square \text { DOE-RL } \\
\square \text { CNTR }\end{array}$ & $\begin{array}{l}\text { DIVISION: } \\
\square \text { State } \\
\square \text { Federal. } \\
\square \text { DOE } \\
\square \text { RCRA } \\
\square \text { TPA Number } \\
\end{array}$ & $\begin{array}{l}\text { DELIVERABLE: } \\
\square \text { Report } \\
\square \text { Letter } \\
\square \text { Drawings } \\
\text { 冈 Other (specify) } \\
\text { Plan }\end{array}$ & $\begin{array}{l}\text { ADDRESS TO: } \\
\square \text { DOE-HQ } \\
\square \text { DOE-RL } \\
\square \text { Other (specify) }\end{array}$ \\
\hline
\end{tabular}

Milestone description:

Prepare the Human Resources Site Support Program Plan. Report baseline compliance and, as required, utilize the formal change control process to ensure baseline integrity.

$\begin{array}{ll}M & .1 \\ \text { Ex } & .3 \\ \text { Nx } & .2\end{array}$

Description of what constitutes completion of this milestone:

Submittal of the Human Resources Site Support Program Plan by

August 31, 1995.

\begin{tabular}{|c|c|c|c|}
\hline $\begin{array}{l}\text { st Account Manager } \\
\text { H. Hammond }\end{array}$ & Date & $\begin{array}{l}\text { Program/Project Manager } \\
\text { L. L. Myers }\end{array}$ & Date \\
\hline Program Element Manager & Date & $\begin{array}{l}\text { DOE Monitor } \\
\text { S. A. Hostick }\end{array}$ & Date \\
\hline
\end{tabular}




\section{Westinghouse Hanford Company \\ MILESTONE DESCRIPTION SHEET}

\begin{tabular}{|c|c|c|c|}
\hline Westinghouse Hanfor & npany Staffing & & $\begin{array}{l}\text { Date: } \\
09 / 23 / 94 \\
\end{array}$ \\
\hline \multicolumn{3}{|l|}{ Assigned To: } & CIN: \\
\hline \multicolumn{3}{|c|}{$\begin{array}{l}\text { Program WBS Designator: } \\
6.10 .2 .6\end{array}$} & $\begin{array}{c}\text { Due Date: } \\
11 / 15 / 94 \\
\end{array}$ \\
\hline \multicolumn{3}{|c|}{ Control Number: FAH-95-018 } & Rev.: \\
\hline $\begin{array}{l}\text { MILESTONE TYPE: } \\
\square \text { DOE-HQ } \\
\square \mathrm{X} \text { DOE-RL } \\
\square \text { CNTR }\end{array}$ & $\begin{array}{l}\text { DIVISION: } \\
\square \text { State } \\
\square \text { Federal } \\
\square \text { DOE } \\
\square \text { RCRA } \\
\square \text { TPA Number } \\
\end{array}$ & $\begin{array}{l}\text { DELIVERABLE: } \\
\square \text { Report } \\
\square \text { Letter } \\
\square \text { Drawings } \\
\mathbb{D} \text { Other (specify) } \\
\text { Plan }\end{array}$ & $\begin{array}{l}\text { ADDRESS TO: } \\
\square \text { DOE-HQ } \\
\square \text { DOE-RL } \\
\square \text { Other (specify) }\end{array}$ \\
\hline
\end{tabular}

Milestone description:

Develop the WHC/BCSR/ICF KH Staffing PIan based on FTE forecasts contained

in the Muti-year Program Plans and Site Support Program Plans.

The Staffing Plan will be developed in a format compatable with the requirements of the Workforce Transition Model.

$\begin{array}{ll}M & .1 \\ \text { Ex } & .4 \\ \mathrm{Nx} & .2\end{array}$

Description of what constitutes completion of this milestone:

Submittal of the Staffing Plan by November 15, 1994 is contingent upon RL

approval of the subject planning documents by October 1,1994 .

\begin{tabular}{|c|c|c|c|}
\hline $\begin{array}{l}\text { ist Account Manager } \\
\text { H. Hammond }\end{array}$ & Date & $\begin{array}{l}\text { Program/Project Manager } \\
\text { L. L. Myers }\end{array}$ & Date \\
\hline Program Element Manager & Date & $\begin{array}{l}\text { DOE Monitor } \\
\text { S. A. Hostick }\end{array}$ & Date \\
\hline
\end{tabular}




\section{Westinghouse Hanford Company \\ MILESTONE DESCRIPTION SHEET}

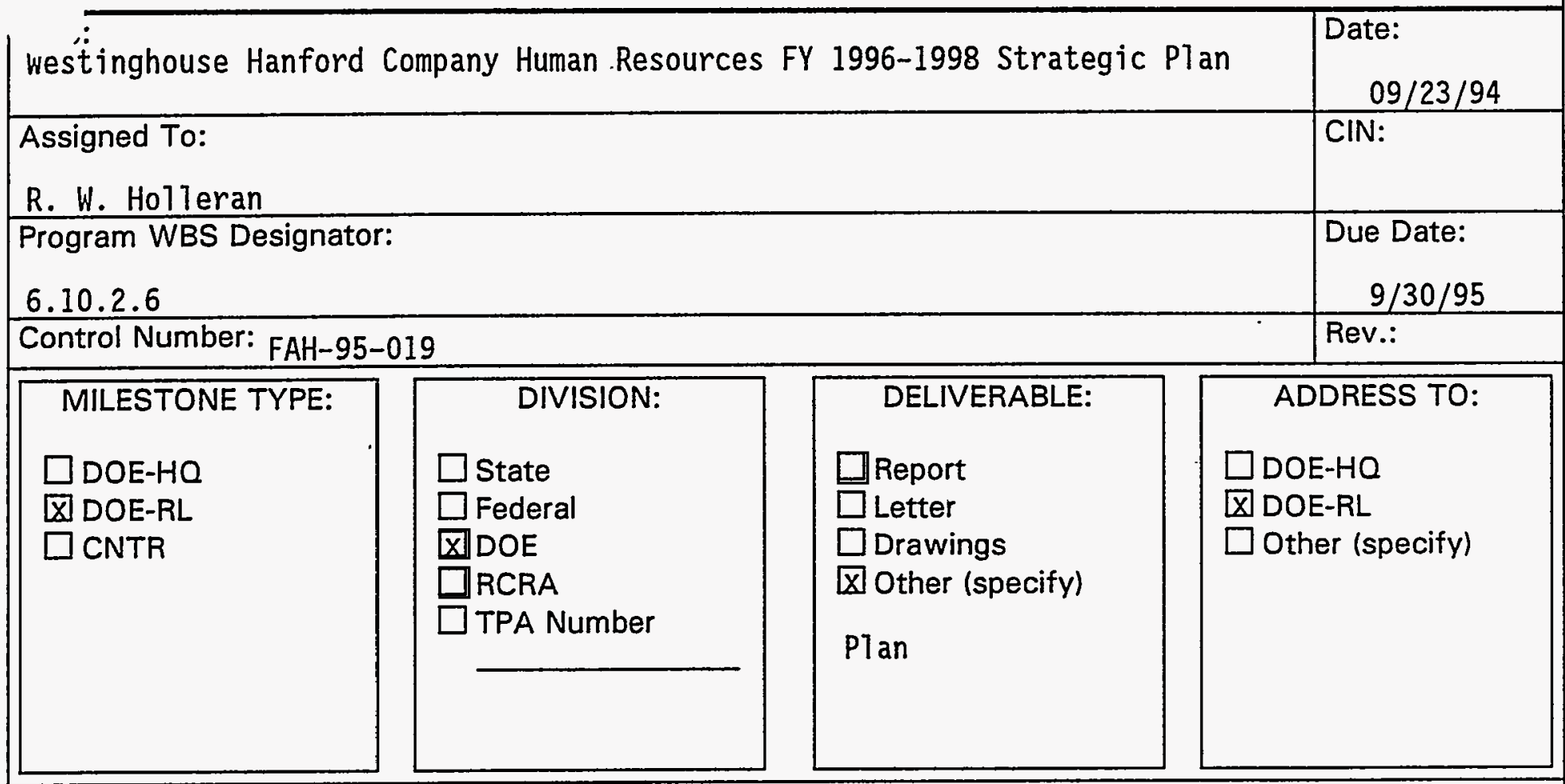

Milestone description:

Development of the Westinghouse Hanford Company Human Resources Strategic

Plan to provide the basic structure to lead Human Resources, and WHC,

through the challenges of the upcoming year.

$\begin{array}{ll}M & .1 \\ N \times & .1\end{array}$

Description of what constitutes completion of this milestone:

Submittal of the Westinghouse Hanford Company Human Resources Strategic Plan to RL by September 30, 1995.

st Account Manager

1... W. Holleran

Program Element Manager
Date

Date
Program/Project Manager

L. L. Myers

DOE Monitor

S. A. Hostick
Date

Date 


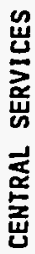

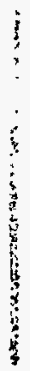




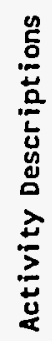




\begin{tabular}{|c|c|c|}
\hline 1.A Vision/Mission & $\begin{array}{l}\text { Westinghouse Hanford Company } \\
\text { HR Central Services } \\
\text { SMS/HBS No. } 6.10 .2 .3\end{array}$ & $\begin{array}{l}\text { FY } 1995 \\
\text { Site Support Program P1an } \\
\text { Date Prepared: } \quad 8 / 12 / 94\end{array}$ \\
\hline
\end{tabular}

\section{GENERAL VISION/MISSION STATEMENT}

The mission of Human Resources Central Services is to provide highly responsive, efficient and costeffective programs and services required by our customers in meeting/exceeding Department of Energy and Company strategic and operating objectives for Compensation, Benefits Administration, Recruitment, Employment Operations, Personnel Records/Database Administration and Administrative Services. 


\section{B.1 Internal Assessment Summary}

Westinghouse Hanford Company

HR Central Services

SMS/WBS No. 6.10.2.3
FY 1995

Site Support Program P1an

Date Prepared: 8/12/94

\section{PRIMARY CUSTOMERS}

Department of. Energy, Richland Operations Office (RL), Industrial Relations

RL Security

A11 Westinghouse Hanford Company (WHC)/BCS Richland, Inc. (BCSR), ICF Kaiser Hanford Company (ICF KH) and Bechtel Hanford Inc. (BHI) employees

BHI and its subcontractors

Mactec and other contractors as designated by the Department of Energy Westinghouse/Rockwe11/Boeing/United Nuclear retirees and their beneficiaries

Terminated employees who have pension benefits and/or savings program accounts

Family members of employees who are covered by Company benefits

WHC employment candidates

Westinghouse Electric Corporation

Washington State Department of Labor and Industries

United States Department of Transportation

United States Department of Labor, Office of Federal Contracts Compliance Programs

United States Department of Immigration and Naturalization Services

Washington State Employment Security Department

Washington State Human Rights Commission 


\begin{tabular}{|c|c|c|}
\hline & Westinghouse Hanford Company & FY 1995 \\
H.B.1 Internal Assessment Summary & $\begin{array}{c}\text { Sentral Services } \\
\text { SMS/WBS No.6.10.2.3 }\end{array}$ & $\begin{array}{c}\text { Site Support Program P1an } \\
\text { Date Prepared: } 8 / 12 / 94\end{array}$ \\
\hline
\end{tabular}

\section{PRODUCTS/SERVICES PROVIDED}

General employment

Employment candidate recruiting to meet special requirements

Outplacement services administration

Pre-employment investigations

Internal job posting systems for Hanford Atomic Metal Trades Council (HAMTC) represented, exempt and nonexempt positions

Salary planning, implementation and administration

Job evaluations

Job offer preparation

Worker's Compensation administration

Employment verifications

Employee service adjustments

Employee personnel data and file maintenance

Unemployment claims

Database maintenance and system integration implementation

Benefit plans and program development for WHC/BCSR, ICF KH and BHI

Savings programs administration for WHC/BCSR, ICF KH, BHI, Battelle Northwest Laboratories (BNL) HAMTC represented and non-represented employees 


\begin{tabular}{|c|c|c|c|}
\hline 1.B.1 & Internal Assessment Summary & $\begin{array}{l}\text { Westinghouse Hanford Company } \\
\text { HR Central Services } \\
\text { SMS/WBS No.6.10.2.3 }\end{array}$ & $\begin{array}{l}\text { FY } 1995 \\
\text { Site Support Program Plan } \\
\text { Date Prepared: } \quad 8 / 12 / 94 \\
\end{array}$ \\
\hline
\end{tabular}

PRODUCTS/SERVICES PROVIDED (continued)

Pension plan administration for WHC/BCSR, ICF KH and BHI

Health and life insurance programs administration for WHC/BCSR, ICF KH and BHI

Leave of absence administration

Disability administration

Service recognition program

Health promotion activities and coordination

Hourly employee assignment and tracking administration

Retiree medical and life insurance coverage/administration

New hire and random drug screening programs administration

Personnel Security Assurance Program (PSAP) and Technical Data Package (TDP) program administration

\section{MAJOR ACTIVITIES PERFORMED TO DELIVER PRODUCTS AND SERVICES}

Administer internal job posting systems for management, bargaining unit, exempt and nonexempt positions

Perform pre-employment candidate evaluations

Recruit employment candidates for all types of job skills

Develop outplacement programs and administer outplacement activities

Provide individual employee outplacement and reassignment assistance

Maintain/track and distribute resumes and applications

HR Central Services 


\begin{tabular}{|c|c|c|c|}
\hline 1.B.1 & Internal Assessment Summary & $\begin{array}{l}\text { Westinghouse Hanford Company } \\
\text { HR CentraT Services } \\
\text { SMS/WBS No.6.10.2.3 }\end{array}$ & $\begin{array}{l}\quad \text { FY } 1995 \\
\text { Site Support Program Plan } \\
\text { Date Prepared: } 8 / 12 / 94\end{array}$ \\
\hline
\end{tabular}

\section{MAJOR ACTIVITIES PERFORMED TO DELIVER PRODUCTS AND SERVICES (continued)}

Represent the Company at job fairs

Target and schedule interviews at colleges to promote workforce diversity

Ensure employment coordination in compliance with 3161 restructuring requirements

Develop recruitment 1 iterature and displays

Identify internal and external employment candidates for management

Provide interviewer training

Administer outsourced contracts to compile recruitment information and make travel arrangements

Ensure all new hires are properly oriented, badged, etc

Coordinate content and conduct New Employee Orientation classes for new hires

Track staffing levels to authorized hiring criteria

Assure surplus employee priority consideration for open positions and placement

Prepare job offers for external and internal employment candidates

Administer Worker's Compensation claims

Perform job evaluations for title, grade and salary considerations

Administer Company compensation programs to ensure fair treatment for a11 employees

Manage special incentive and awards programs

Manage Worker's Compensation programs 
MAJOR ACTIVITIES PERFORMED TO DELIVER PRODUCTS AND SERVICES (continued)

Conduct salary and benefit surveys

Conduct job evaluations

Perform salary planning and monitoring

Maintain employee job descriptions

Perform reorganization analysis and implement appropriate changes

Maintain all employee official personnel files and data

Provide personnel statistical reports through accurate data maintenance, retrieval and downioads to other electronic systems

Implement integration of all employee personnel data and systems

Maintain official Company organization charts

Act as official Company source for employee status

Administer Overtime Management System for HAMTC represented empioyees

Perform database administration and evaluation for personnel records and activities

Coordinate and provide Human Resources computer acquisition, deployment and tracking

Provide Company statistical reports as related to employee data, such as headcount summaries and attrition

Represent WHC at unemployment claim hearings

Administer personnel/payroll record data for corporate transferees 
MAJOR ACTIVITIES PERFORMED TO DELIVER PRODUCTS AND SERVICES (continued)

Perform data entry to ensure all employees pay and other personal data is accurate and timely

Notify appropriate Company organizations of employee terminations

Provide data files for creation of official Company organization charts

Administer WHC Service Recognition program

Design, develop and maintain all employee benefit plans and programs (savings plans, pension, disability and life, accident insurance,) for WHC/BCSR, ICF KH and BHI.

Determine and track eligibility of employees, retirees and their dependents for benefit programs. Provide retiree medical and life insurance services

Administer COBRA and other post employment insurance programs

Administer employee short- and long-term disability claims and coordinate absence administration

Evaluate and analyze benefit plan design and costs

Develop plans to meet changing needs and to maintain competitive plans

Administer the WHC hourly support staff in responding to peak work loads and specialized program needs

Administer the Human Reliability program which includes:

- Substance abuse testing for compliance with the Department of Transportation Commercial Drivers License as outlined in Title 49 , Code of Federal Regulations, Part 40

- Personnel Security Assurance Program positions which require special access and ongoing evaluation

- Testing designated positions program per 707, U.S. Department of Energy 


\section{B.1 Internal Assessment Summary}

Westinghouse Hanford Company

HR Central Services SMS/WBS No.6.10.2.3
FY 1995

Site Support Program Plan Date Prepared: $8 / 12 / 94$

MAJOR ACTIVITIES PERFORMED TO DELIVER PRODUCTS AND SERVICES (continued)

- $\quad$ Pre-employment substance abuse testing

- Substance abuse testing contract

- Act as primary interface with Medical Review Office

\section{EVALUATION OF MAJOR ACTIVITIES (COST, VALUE-ADDED, ETC.)}

Real Value-Added activities associated with a central organization providing a total company oversight for benefits administration, personnel data administration, compensation and employment ensures consistent treatment, accurate overall reporting, and minimized redundant activities.

Utilizing a central employment organization allows expanded visibility of both internal and external employment applicants and better assists excess employees in outplacement activities.

To ensure compliance with federal and state agencies, a central system of reporting different kinds of employee information is required.

\section{FACTORS WHICH INFLUENCE RESOURCE CONSUMPTION (CHANGES TO COST AND VOLUME)}

Special requests from WHC management, Department of Energy, RL and Headquarters, Westinghouse corporate and other contractors results in an inability to $\mathrm{p}$ lan resources for these requests versus normal work activities. This causes overtime and/or delays in completing other activities.

Drive to reduce overhead (budget funded by WHC overhead) has resulted in reductions to staff. The turnaround on requests is impacted to varying degrees. The sizing of staff levels has not been determined; however, the strategy has not been fully developed due to uncertainty of special programs and outsourcing in various parts of the Company.

Staff realignment and changing responsibilities influence turnaround on both special requests and normal work. This should improve as staffing and responsibilities become more settled.

Customer base is increasing while staffing levels are decreasing. 


\section{B.1 Internal Assessment Summary}

Westinghouse Hanford Company

HR Central Services SMS/WBS No.6.10.2.3
FY 1995

Site Support Program Plan Date Prepared: 8/12/94

\section{FACTORS HHICH INFLUENCE RESOURCE CONSUMPTION (CHANGES TO COST AND VOLUME) (continued)}

Addition of employee groups to benefit plans complicate the administrative responsibilities, i.e., ICF KH on $1 / 93$ and BHI and its subcontractors on $7 / 94$.

Special programs such as a retirement incentive and voluntary reductions in force demand significant effort to plan, communicate and implement.

\section{FACTORS THAT INFLUENCE CHANGES IN TYPES OR NATURE OF PRODUCTS and SERVICES}

. HR planned modular implementation of software integrating over 70 systems will streamline information retrieval and facilitate certain process improvements.

Work elements identified for outsourcing and resultant potential impact on staffing.

The early retirement, voluntary and involuntary separation program schedules will greatly impact work load and priorities.

The final draft of the 3161 Restructuring P1an and the Company's subsequent planning.

Department of Energy regulation, 10 CFR 707 on random drug screening.

Department of Energy order 5631.6A, Personnel Security Assurance Program.

Department of Transportation 49 CFR-40 substance testing.

Further ICF KH, WHC or other company integration.

Staff alignment with Company projects. 


\section{OTHER EXTERNAL CHALLENGES}

Federal/State legislation such as drug testing, DOE 10-CFR-707, DOT 49 CFR-40 and DOE order 5631.64 (PSAP), 3161 (restructuring), Americans with Disabilities Act, 10 CFR impact advance work planning efforts.

Providing assistance to local, state and federal stakeholders requesting personnel and compliance information requires additional, sometimes unplanned work.

Workforce integration model results will require some level of effort. 


\begin{tabular}{|c|c|c|}
\hline 1.C Goals and Objectives & $\begin{array}{c}\text { Westinghouse Hanford Company } \\
H R \text { Central Services } \\
\text { SMS/WBS No. } 6.10 .2 .3\end{array}$ & $\begin{array}{l}\text { FY } 1995 \\
\text { Site Support Program P1an } \\
\text { Date Prepared: } \quad 8 / 12 / 94\end{array}$ \\
\hline
\end{tabular}

\section{GOALS}

Develop and recommend compensation programs that reinforce assignment flexibility, improved span of management, employee ownership, and retention.

Provide targeted staffing and strategic redeployment service to support program requirements and organizational restructuring.

Design, develop, implement and administer employee benefit programs with emphasis on cost containment and quality.

Lead and facilitate the integration and improved management of automated personnel data retrieval and information access.

Implement drug/alcohol testing programs to be continual1y in ful1 compliance with applicable regutations.

Continue targeted process improvement/cost reduction focus in all functions.

\section{OBJECTIVES (special focus)}

Evaluate and appropriately adjust Central Services staff deployment to address changes resulting from Company restructuring and program needs.

Investigate and evaluate outsourcing opportunities for Central Services work scope.

Be proactive in consolidating, integrating and realigning service elements to improve cost, efficiency and program support.

Improve administrative efficiency and achieve additional cost reductions by targeting strategic process improvements, program design and service delivery vehicles in each function.

Enhance service and customer satisfaction in responding to changing Company needs through customer feedback vehicles, benchmarking and performance measures. 


\begin{tabular}{|l|c|c|}
\hline & Westinghouse Hanford Company & FY 1995 \\
HR Central Services & Site Support Program Plan \\
Date Prepared: $8 / 12 / 94$
\end{tabular}

\section{CUSTOMER SUPPORT STRATEGIES}

Continue to develop and enhance routine working relationships and interfaces with Department of Energy, Richland Operations Human Resources personnel.

Ensure that HR Central Services staff understands the use and need for information and that they consider viable alternative sources for such information.

\section{PRODUCTION STRATEGIES}

Based upon reality of reduced staff levels, put emphasis/focus on identifying alternatives to produce products/services in a more cost effective manner. Review organizational staff mix to align staff skilis/strengths with priority work.

\section{ORGANIZATION and MANAGEMENT STRATEGIES}

Staff mix to be determined as changes resulting from continued WHC, ICF KH integration, BHI transition and our ability to identify alternative methods and sources are increased. 


\begin{tabular}{|c|c|c|}
\hline 1.E Assumptions & $\begin{array}{c}\text { Hestinghouse Hanford Company } \\
\text { HR Central Services } \\
\text { SMS/WBS No. } 6.10 .2 .3\end{array}$ & $\begin{array}{l}\text { FY } 1995 \\
\text { Site Support Program Plan } \\
\text { Date Prepared: } \quad 8 / 12 / 94\end{array}$ \\
\hline
\end{tabular}

\section{ASSUMPTIONS}

Employment will decrease through special retirement, voluntary and involuntary programs during FY 1995.

Full scope outplacement activities to assist department employees will be required.

Reorganizations and resultant employee reassignments will continue and heavily impact Central Services staff.

Internal job posting system may be restricted or continue in suspended status.

Medical costs will continue to escalate. Federal and state health insurance legislation in progress. Alcohol testing will be initiated and additional critical positions will be added to PSAP program. 


\begin{tabular}{|l|c|c|}
\hline & Westinghouse Hanford Company & FY 1995 \\
HR Central Services & Site Support Program Plan \\
SMS/WBS No. 6.10.2.3 & Date Prepared: $8 / 12 / 94$
\end{tabular}

\section{ISSUES AND CONSTRAINTS}

Potential for additional Hanford employer activity integration and leveraged outsourcing -- employee and program impacts.

Aftereffect of final 3161 Restructuring Plan/subsequent reporting and administration.

Ski11 mix residual after voluntary retirement programs -- accommodating strategic critical voids.

Required outplacement activities must draw upon staff from other Central Services functions.

Normal workload, plus additional demands, will not result in pro rata proportion with decline in Company staffing in short term. 


\begin{tabular}{|l|c|c|}
\hline 1.G Performance Measures & $\begin{array}{c}\text { Westinghouse Hanford Company } \\
\text { HR Central Services } \\
\text { SHS/WBS No.6.10.2.3 }\end{array}$ & $\begin{array}{c}\text { FY 1995 } \\
\text { Site Support Program PIan } \\
\text { Date Prepared 8/12/94 }\end{array}$ \\
\hline
\end{tabular}

\section{PERFORMANCE MEASURES}

Cycle time for delivery of services

Interview date vs. tender of offer

Interview date vs. sign-on

Job offer preparation

Job posting schedule

Pre-employment turnaround

Requested ad hoc report

Escalation of health care costs vs. national norms and internal historical cost trends

Levels of management

Span of management

Average salary grade

Average salary range penetration

Attrition

Performance vs. ECCEL goal

Process improvement dollars

Reduced salary budget dollars

Customer service surveys 


\begin{tabular}{|c|c|}
\hline 2.A.2 Description of Activities & $\begin{array}{l}\text { Westinghouse Hanford Company } \\
\text { HR Central Service } \\
\text { Compensation } \\
\text { SMS/HBS No. } 6.10 \cdot 2 \cdot 3.1 \\
\end{array}$ \\
\hline ACTIVITY & DESCRIPTION \\
\hline $\begin{array}{l}\text { Annual salary planning } \\
1.5 \text { Ex }\end{array}$ & $\begin{array}{l}\text { To insure that the nearly } 9,000 \text { exempt and salaried nonexempt WHC, } \\
\text { BCSR and ICF KH employees are considered and adequately reviewed } \\
\text { for } 1995 \text { merit planning. }\end{array}$ \\
\hline $\begin{array}{l}\text { Adjust Salary Schedules } \\
.1 \text { Ex }\end{array}$ & $\begin{array}{l}\text { To reflect changes in the market (exempt and } N x \text { ) and to reflect } \\
\text { results of contract negotiations (B.U.) }\end{array}$ \\
\hline $\begin{array}{c}\text { Update Salary Planning Software } \\
.1 \mathrm{Ex}\end{array}$ & $\begin{array}{l}\text { To reflect changes in schedules and guidelines to nearly } 1,400 \text { WHC, } \\
\text { BCSR and ICF KH managers for use in salary planning. }\end{array}$ \\
\hline $\begin{array}{c}\text { Prepare Salary Planning Guidelines } \\
.1 \mathrm{Ex}\end{array}$ & $\begin{array}{l}\text { To assure consistency and equity in salary planning by nearly } 1,400 \\
\text { managers. }\end{array}$ \\
\hline $\begin{array}{c}\text { Track Salary Fund Expenditure } \\
.1 \text { Ex }\end{array}$ & $\begin{array}{l}\text { To insure proper allocation of fund and to complete Annual Salary } \\
\text { Income Fund Expenditure Report for DOE. }\end{array}$ \\
\hline $\begin{array}{c}\text { Prepare Salary Planning Summary } \\
\text { Reports } \\
.1 \text { Ex }\end{array}$ & $\begin{array}{l}\text { To insure an equitable distribution of merit funds to females and } \\
\text { minorities and to develop final salary plan. }\end{array}$ \\
\hline $\begin{array}{c}\text { Prepare Salary Offer Guidelines } \\
.1 \mathrm{Ex}\end{array}$ & $\begin{array}{l}\text { To insure consistency when preparing internat and externat salary } \\
\text { offers. }\end{array}$ \\
\hline $\begin{array}{c}\text { Conduct meetings of the } \\
\text { Engineering/Scientist Appointment } \\
\text { Board } \\
.1 \text { Ex }\end{array}$ & $\begin{array}{l}\text { To review appointments for Sr. Principal, Fellow, and Advisor } \\
\text { appointments per MRP } 4.35 \text {. }\end{array}$ \\
\hline $\begin{array}{l}\text { Conduct Job Evaluations } \\
.5 \mathrm{Ex}\end{array}$ & $\begin{array}{l}\text { To review new and revised positions to determine appropriate grade } \\
\text { and FLSA status. }\end{array}$ \\
\hline $\begin{array}{l}\text { Submit Requests to DOE } \\
\qquad .1 \mathrm{EX}\end{array}$ & $\begin{array}{l}\text { To insure allocability for salary actions over } 80 \mathrm{~K} \text { and over-range } \\
\text { maximum per appendix "A". }\end{array}$ \\
\hline $\begin{array}{l}\text { Managerial functions } \\
\quad .8 \mathrm{Ex}\end{array}$ & $\begin{array}{l}\text { Performance review, budget planning, performance indicators, } \\
\text { counseling, corporate compensation interface, etc. }\end{array}$ \\
\hline
\end{tabular}




\begin{tabular}{|c|c|}
\hline 2.A.2 Description of Activities & $\begin{array}{l}\text { Hestinghouse Hanford Company } \\
\text { HR Central Service } \\
\text { Compensation } \\
\text { SMS/WBS No. } 6.10 .2 .3 .1\end{array}$ \\
\hline ACTIVITY & DESCRIPTION \\
\hline $\begin{array}{l}\text { Interface with } \mathrm{W} \text { Corporate } \\
\text { Compensation and Business Unit } \\
\qquad .1 \mathrm{Nx} \\
.2 \mathrm{Ex}\end{array}$ & $\begin{array}{l}\text { For compensation issues relating to incentive eligibility, } \\
\text { executive salary planning, stock options, and grading letters. }\end{array}$ \\
\hline $\begin{array}{l}\text { Prepare and Maintain Job } \\
\text { Descriptions } \\
.5 \mathrm{Ex} \\
.1 \mathrm{Nx}\end{array}$ & $\begin{array}{l}\text { To reflect' current job scope and to use in job evaluation for a } 11 \\
\text { manager, exempt professional and salaried nonexempt positions. }\end{array}$ \\
\hline $\begin{array}{l}\text { Prepare Salary Offers } \\
2.0 \text { Ex }\end{array}$ & $\begin{array}{l}\text { To determine appropriate rate to pay external hires and internal } \\
\text { promotions to maintain fairness and equity. }\end{array}$ \\
\hline $\begin{array}{c}\text { Implement Company Reorganizations } \\
1.2 \text { Ex }\end{array}$ & $\begin{array}{l}\text { To insure proper realignment of staff and to determine appropriate } \\
\text { grades of management hierarchy. }\end{array}$ \\
\hline $\begin{array}{l}\text { Approve changes in Continuity of } \\
\text { Service } \\
.2 \mathrm{Ex} \\
.4 \mathrm{Nx} \\
\end{array}$ & For appropriate vacation accrual and service awards calculations. \\
\hline $\begin{array}{l}\text { Process Verifications of Employment } \\
.5 \mathrm{Nx} \\
\end{array}$ & To comply with requests from financial institutions. \\
\hline $\begin{array}{l}\text { Process Workers Compensation claims } \\
\text { and maintain data base } \\
1.0 \mathrm{Nx}\end{array}$ & To comply with state law related to employees injured on the job. \\
\hline $\begin{array}{c}\text { Manage active Workers Compensation } \\
\text { claims and process return-to-work } \\
1.7 \text { Ex }\end{array}$ & $\begin{array}{l}\text { To follow up with employees, physicians, and vocational } \\
\text { rehabilitation counselors on status of employees off work and to } \\
\text { assist in their return-to-work. }\end{array}$ \\
\hline $\begin{array}{l}\text { Secretarial and administrative } \\
\text { support } \\
.9 \mathrm{Nx}\end{array}$ & $\begin{array}{l}\text { Open and distribute mai1, answer telephones, prepare } \\
\text { correspondence, reports, data entry, budget, expense accounts, } \\
\text { charts, graphs and make travel arrangements. }\end{array}$ \\
\hline
\end{tabular}

HR Central Services Compensation Page 17 
 


\begin{tabular}{|c|c|}
\hline 2.A.2 Description of Activities & $\begin{array}{l}\text { Westinghouse Hanford Company } \\
\text { HR Central Services } \\
\text { Benefits Administration } \\
\text { SMS/WBS No. 6.10.2.3.2 }\end{array}$ \\
\hline ACTIVITY & DESCRIPTION \\
\hline $\begin{array}{c}\text { Benefits Analysis \& Design } \\
.3 \text { Ex }\end{array}$ & $\begin{array}{l}\text { Analyze benefit programs from cost \& coverage points of view, } \\
\text { compare with competition, consider trends, and identify probiem } \\
\text { areas. Design new and modified plans to meet identified needs. }\end{array}$ \\
\hline $\begin{array}{l}\text { Benefits Communications } \\
.3 \mathrm{Ex}\end{array}$ & $\begin{array}{l}\text { Communicate plan provisions, changes, procedures, etc. to covered } \\
\text { individuals-employees, dependents, retirees. On request, brief } \\
\text { groups of employees on various benefits issues. }\end{array}$ \\
\hline $\begin{array}{l}\text { Plan Interpretation } \\
.2 \text { Ex }\end{array}$ & $\begin{array}{l}\text { Interpret written plans to respond to particular questions and/or } \\
\text { problems. }\end{array}$ \\
\hline $\begin{array}{l}\text { Customer Service } \\
.1 \mathrm{Ex} \\
.5 \mathrm{Nx}\end{array}$ & $\begin{array}{l}\text { Respond to employee questions and comments regarding benefits. } \\
\text { Assist them in obtaining the benefits available to them under the } \\
\text { Company benefits package. }\end{array}$ \\
\hline $\begin{array}{l}\text { Problem Resolution } \\
.3 \mathrm{Ex}\end{array}$ & $\begin{array}{l}\text { Respond to individual and collective problems relating to benefits, } \\
\text { analyzing the situation, recommending and implementing solutions } \\
\text { which are in the best interest of the employee and the plan. }\end{array}$ \\
\hline $\begin{array}{c}\text { Benefits Eligibility Administration } \\
.1 \mathrm{Ex} \\
.2 \mathrm{Nx}\end{array}$ & $\begin{array}{l}\text { Identify, monitor and implement procedures for determining } \\
\text { eligibility for benefits programs. Maintain eligibility } \\
\text { information, coordinating with administrators such as CIGNA and } \\
\text { Group Health. }\end{array}$ \\
\hline $\begin{array}{c}\text { Benefits Enrollments } \\
.1 \mathrm{Nx}\end{array}$ & $\begin{array}{l}\text { Conduct annual benefits enroliment (e.g., annual choice of CIGNA or } \\
\text { Group Health/Dental or Dental Plus, etc.) Communicate rules to } \\
\text { covered individuals, receive and process requested changes. }\end{array}$ \\
\hline $\begin{array}{l}\text { Manage third party administrators } \\
\text { and providers } \\
\text {.2 Ex }\end{array}$ & $\begin{array}{l}\text { Participate in selection, development, implementation and } \\
\text { evaluation of administrative services providers and insurers for } \\
\text { Company benefit plans(e.g., CIGNA, Group Universal Life and Group } \\
\text { Health). }\end{array}$ \\
\hline
\end{tabular}




\begin{tabular}{|c|c|}
\hline 2.A.2 Description of Activities & $\begin{array}{l}\text { Westinghouse Hanford Company } \\
\text { HR Central Services } \\
\text { Benefits Administration } \\
\text { SMS/WBS No. } 6.10 .2 .3 .2\end{array}$ \\
\hline ACTIVITY & DESCRIPTION \\
\hline $\begin{array}{l}\text { Employee Contributions } \\
\qquad .5 \mathrm{Ex}\end{array}$ & $\begin{array}{l}\text { Assess costs in the prior calendar year and determine related } \\
\text { employee contribution rates for medical and other coverage. } \\
\text { Communicate rates to employees and effect changes in the payroll } \\
\text { system. }\end{array}$ \\
\hline $\begin{array}{c}\text { Implement new/changed benefits } \\
.1 \text { Ex }\end{array}$ & $\begin{array}{l}\text { Identify, evaluate, cost, secure approval, and implement new plans } \\
\text { or changes to meet Company needs or as negotiated. }\end{array}$ \\
\hline $\begin{array}{c}\text { Special Separations Programs } \\
1.2 \mathrm{Ex} \\
.5 \mathrm{Nx}\end{array}$ & $\begin{array}{l}\text { Design, develop, cost, communicate and implement separations } \\
\text { programs including special retirements and voluntary and } \\
\text { involuntary reductions of force. Provide continuing benefits } \\
\text { services to affected individuals. }\end{array}$ \\
\hline $\begin{array}{c}\text { Service Recognition Program } \\
.15 \mathrm{Ex} \\
.1 \mathrm{Nx}\end{array}$ & $\begin{array}{l}\text { Administer the WHC Service Recognition Program - identify eligible } \\
\text { employees, order and distribute awards, plan and coordinate awards } \\
\text { functions (e.g. breakfasts) as appropriate. }\end{array}$ \\
\hline $\begin{array}{l}\text { Retirement Administration } \\
.4 \mathrm{Ex} \\
.2 \mathrm{Nx}\end{array}$ & $\begin{array}{l}\text { Manage the retirement program - advise employees of retirement } \\
\text { benefits and procedures and process retirements. }\end{array}$ \\
\hline $\begin{array}{l}\text { Retiree Liaison } \\
.5 \mathrm{Ex} \\
\end{array}$ & $\begin{array}{l}\text { Maintain appropriate contact with retirees regarding benefits and } \\
\text { changes which might affect them. }\end{array}$ \\
\hline $\begin{array}{c}\text { Short/Long Term Disability and } \\
\text { related absence administration } \\
1.2 \mathrm{Ex} \\
.5 \mathrm{Nx}\end{array}$ & $\begin{array}{l}\text { Administer Short and Long Term Disability Plans including employee } \\
\text { and management counseling and communication, claims processing, and } \\
\text { development of progressive disability programs. Coordinate } \\
\text { administrative interface with internal and external organizations } \\
\text { involved in administration of the Plans. }\end{array}$ \\
\hline
\end{tabular}

HR Central Service 


\begin{tabular}{|c|c|}
\hline 2.A.2 Description of Activities & $\begin{array}{l}\text { Hestinghouse Hanford Company } \\
\text { HR Central Services } \\
\text { Benefits Administration } \\
\text { SMS/WBS No. } 6.10 .2 .3 .2 \\
\end{array}$ \\
\hline ACTIVITY & DESCRIPTION \\
\hline $\begin{array}{c}\text { Benefits Reporting } \\
.1 \mathrm{Ex}\end{array}$ & $\begin{array}{l}\text { Provide benefits cost and other analyses as required including: } \\
\text { a) the annual "Report of Contractor Expenditures for Group } \\
\text { Insurance and other Health Benefits Program Costs" to the } \\
\text { Department of Energy, and } \\
\text { b) quarterly benefits cost reports to Westinghouse Electric. }\end{array}$ \\
\hline $\begin{array}{l}\text { Surveys } \\
.5 \mathrm{EX}\end{array}$ & $\begin{array}{l}\text { Participate in and/or respond to various national surveys regarding } \\
\text { benefits programs and costs. Evaluate data from such surveys as. } \\
\text { part of the overall review of WHC plans. }\end{array}$ \\
\hline $\begin{array}{l}\text { Health Promotion } \\
\text {.4 Ex }\end{array}$ & $\begin{array}{l}\text { Coordinate health promotion and wellness education and other } \\
\text { activities for the Company, drawing upon internal and external } \\
\text { resources and information. }\end{array}$ \\
\hline $\begin{array}{l}\text { Pre-Retirement } \\
\text {.1 Ex }\end{array}$ & $\begin{array}{l}\text { Develop and conduct a continuing series of pre-retirement seminars, } \\
\text { evaluating the possibility of adding those not yet retirement- } \\
\text { eligible to the audience. }\end{array}$ \\
\hline $\begin{array}{l}\text { COBRA } \\
.2 \mathrm{EX}\end{array}$ & $\begin{array}{l}\text { Administer health care continuation as defined by COBRA. Identify } \\
\text { strategies to improve the efficiency of this process. Determine } \\
\text { rates for each year and communicate to COBRA participants. }\end{array}$ \\
\hline $\begin{array}{l}\text { Leaves of Absence Administration } \\
.2 \mathrm{Ex}\end{array}$ & $\begin{array}{l}\text { Administer Company Leave of Absence policies, advise HR } \\
\text { representatives, employees and managers on procedures. Process } \\
\text { leaves of absence. }\end{array}$ \\
\hline $\begin{array}{c}\text { ERISA-required communications } \\
.1 \mathrm{EX}\end{array}$ & $\begin{array}{l}\text { Insure timely distribution of ERISA-required information to } \\
\text { employees. Included: Summary Annual Reports in September, Summary } \\
\text { Plan Descriptions, Savings and Pension statements, etc. }\end{array}$ \\
\hline $\begin{array}{l}\text { Stock Purchase Plan } \\
.5 \mathrm{Ex}\end{array}$ & $\begin{array}{l}\text { Notify employees of quarterly enrollment period for the } \\
\text { Westinghouse Stock Purchase Plan. Receive and ensure processing of } \\
\text { employee enrollments. }\end{array}$ \\
\hline
\end{tabular}

HR Central Service

Benefits Administration Page 20 


\begin{tabular}{|c|c|}
\hline 2.A.2 Description of Activities & $\begin{array}{l}\text { Westinghouse Hanford Company } \\
\text { HR Central Services } \\
\text { Benefits Administration } \\
\text { SMS/WBS No.6.10.2.3.2 } \\
\end{array}$ \\
\hline ACTIVITY & DESCRIPTION \\
\hline $\begin{array}{l}\text { Savings P1ans } \\
.5 \mathrm{Ex} \\
1.3 \mathrm{Nx} \\
\end{array}$ & $\begin{array}{l}\text { Provide employees with information and assistance regarding savings } \\
\text { plans. Included: loans, withdrawals, transfer of funds within the } \\
\text { plan and to or from other plans. }\end{array}$ \\
\hline $\begin{array}{l}\text { Westinghouse Electric Corporation } \\
\text { Benefits } \\
.1 \text { Ex }\end{array}$ & $\begin{array}{l}\text { Assist employees who have benefits in the WEC } \mathrm{plans}-\mathrm{i} . e, \text {, } \\
\text { transferees from WEC as we17 as those who were WHC employees prior } \\
\text { to the } 1987 \text { consolidation who participated in the WEC Investment } \\
\text { Plan. }\end{array}$ \\
\hline $\begin{array}{c}\text { Support Union Negotiations relating } \\
\text { to Benefits Issues } \\
.1 \mathrm{Ex}\end{array}$ & $\begin{array}{l}\text { Provide required support to Labor Relations in issues relating to } \\
\text { benefits. }\end{array}$ \\
\hline $\begin{array}{l}\text { Support Bechte1 Hanford Inc. } \\
\text { benefits administration } \\
1.35 \mathrm{Ex} \\
.2 \mathrm{Nx}\end{array}$ & $\begin{array}{l}\text { Administer multi imultiple-employer benefit plans which cover } \\
\text { employees of Bechtel and its subcontractors, as designated, } \\
\text { providing their benefits staff with assistance, training and } \\
\text { information to ensure consistent and fair application of benefits } \\
\text { plans to all covered employees. }\end{array}$ \\
\hline $\begin{array}{l}\text { Benefits Support to } 200 \text {-area and to } \\
\text { Individual Programs } \\
.8 \mathrm{Ex}\end{array}$ & $\begin{array}{l}\text { Provide benefits support to employees in the } 200 \text { area through a } \\
\text { designated representative. Provide support and assistance as } \\
\text { required to HR managers assigned to various program offices. }\end{array}$ \\
\hline $\begin{array}{c}\text { office support/group management } \\
.2 \mathrm{Ex} \\
1.1 \mathrm{Nx}\end{array}$ & $\begin{array}{l}\text { Perform office support answering phones, opening mail, } \\
\text { correspondence for exempt staff, prepare benefit enroiment } \\
\text { material. Group management activities including preparing budgets, } \\
\text { scheduling work, preparing documents/letters and graphs, etc. }\end{array}$ \\
\hline & \\
\hline & \\
\hline
\end{tabular}

HR Central Service Benefits Administration Page 21 


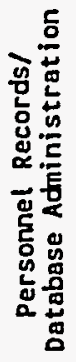




\begin{tabular}{|c|c|}
\hline 2.A.2 Description of Activities & $\begin{array}{l}\text { Westinghouse Hanford Company } \\
\text { HR Central Services } \\
\text { Personnel Records-DB Admin } \\
\text { SHS/HBS No. } 6.10 .2 \cdot 3.3 \\
\end{array}$ \\
\hline ACTIVITY & DESCRIPTION \\
\hline $\begin{array}{c}\text { Personnel file storage } \\
.1 \mathrm{Nx}\end{array}$ & Prepare and store personnel files of terminated employees per RIDS. \\
\hline $\begin{array}{l}\text { Office/group management } \\
.3 \mathrm{Ex} \\
.7 \mathrm{Nx} \\
\end{array}$ & $\begin{array}{l}\text { Perform office and group management activities including preparing } \\
\text { budgets, scheduling work, answering phones, scheduling meetings, } \\
\text { preparing documents/letters, and graphs, etc. }\end{array}$ \\
\hline $\begin{array}{c}\text { Employee personne1 data maintenance } \\
3.4 \mathrm{Nx}\end{array}$ & $\begin{array}{l}\text { Perform all employee personnel data accurately and timely to insure } \\
\text { correct pay and accurate personal information. }\end{array}$ \\
\hline $\begin{array}{c}\text { Database administration } \\
1.4 \mathrm{Ex}\end{array}$ & $\begin{array}{l}\text { Provide personnel data production and ad hoc reports required by } \\
\text { various companies and organizations within the company. }\end{array}$ \\
\hline $\begin{array}{c}\text { Insure personnel data privacy } \\
.1 \mathrm{Nx}\end{array}$ & $\begin{array}{l}\text { Insure that employee's personal information in protected and is } \\
\text { released only as necessary with proper authority. }\end{array}$ \\
\hline $\begin{array}{l}\text { Personnel file structure and audit } \\
\qquad .4 \mathrm{Nx}\end{array}$ & $\begin{array}{l}\text { Continue long term goal to restructure all employee personnel files } \\
\text { into the same format. Perform audit on file content as files are } \\
\text { restructured. }\end{array}$ \\
\hline $\begin{array}{l}\text { Unemployment claims } \\
.3 \mathrm{Ex}\end{array}$ & Represent the company at Washington State unemployment hearings. \\
\hline $\begin{array}{l}\text { Human Resources policies/procedures } \\
\qquad .3 \mathrm{Ex}\end{array}$ & $\begin{array}{l}\text { Insure that al1 Human Resources policies and procedures are } \\
\text { regularly reviewed and revised as necessary. }\end{array}$ \\
\hline $\begin{array}{c}\text { Computer hardware/software } \\
.1 \mathrm{Nx} \\
.1 \mathrm{Ex}\end{array}$ & $\begin{array}{l}\text { Provide overall coordination for purchase and utilization of } \\
\text { computer hardware and software for a11 of Human Resources to insure } \\
\text { maximum benefit from computer equipment and budget. }\end{array}$ \\
\hline $\begin{array}{l}\text { Organization charts and structure } \\
\qquad .8 \mathrm{Nx}\end{array}$ & $\begin{array}{l}\text { Provide current, accurate organization information to al1 who } \\
\text { require it. This entails assigning tracking codes and input } \\
\text { organization changes as they occur. Provide electronic files to } \\
\text { prepare charts. }\end{array}$ \\
\hline
\end{tabular}

HR Central Services

Personnel Records DB Admin. Page 22 


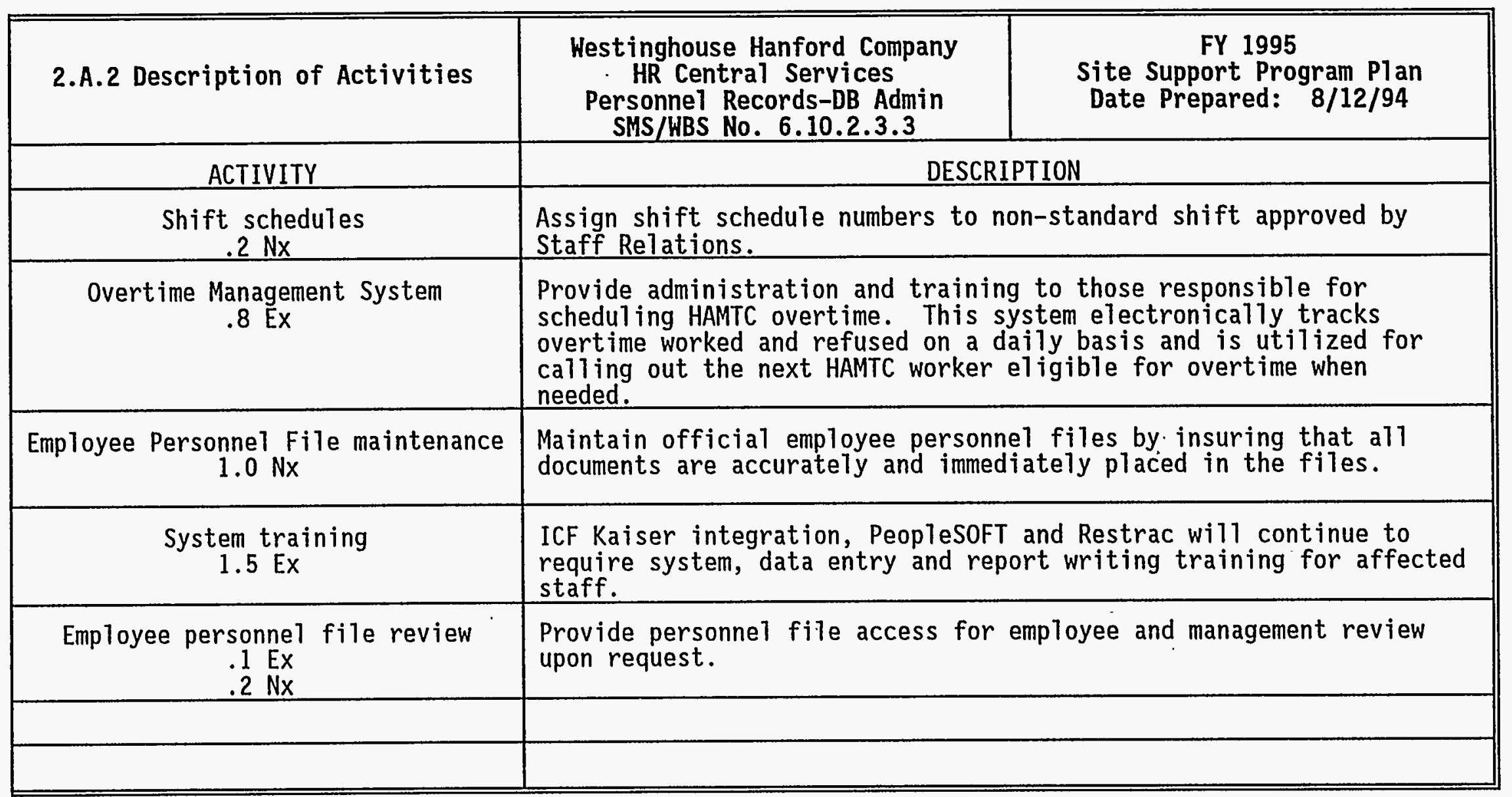




\begin{tabular}{|c|c|c|}
\hline 2.A.2 Description of Activities & $\begin{array}{l}\text { Westinghouse Hanford Company } \\
\text { HR CentraI Services } \\
\text { Recruitment } \\
\text { SMS/HBS No. } \quad 6.10 .2 .3 .5\end{array}$ & $\begin{array}{l}\text { FY } 1995 \\
\text { Site Support Program P1an } \\
\text { Date Prepared: } 8 / 12 / 94\end{array}$ \\
\hline ACTIVITY & \multicolumn{2}{|c|}{ DESCRIPTION } \\
\hline $\begin{array}{l}\text { Identify and recruit employment } \\
\text { candidates } \\
1.0 \mathrm{Ex} \\
.5 \mathrm{Nx}\end{array}$ & \multicolumn{2}{|c|}{$\begin{array}{l}\text { Develop and implement plan for campus, career fair and technical } \\
\text { society recruiting to identify candidate pool that addresses } \\
\text { specific WHC hiring needs. Identify appropriate employment } \\
\text { agencies, administer agreements, manage interface. Arrange } \\
\text { interviews, coordinate offers, set start dates for those selected } \\
\text { by managers for specific positions. }\end{array}$} \\
\hline $\begin{array}{c}\text { Develop outplacement programs } \\
.8 \mathrm{Ex} \\
.3 \mathrm{Nx}\end{array}$ & \multicolumn{2}{|c|}{$\begin{array}{l}\text { Develop outplacement programs that provide access to DOE resume/job } \\
\text { posting database, job identification and job posting services, } \\
\text { outside interviews, job fairs, resume distribution, resource } \\
\text { library, computer workstations, outplacement workshops, access to } \\
\text { subject experts (credit, financial management, stress management, } \\
\text { retirement planning, etc.), financial assistance information, EAP } \\
\text { services to all empioyees affected by workforce restructuring. }\end{array}$} \\
\hline $\begin{array}{c}\text { Distribute resumes to hiring } \\
\text { managers } \\
1.0 \mathrm{Ex}\end{array}$ & \multicolumn{2}{|c|}{$\begin{array}{l}\text { For each position tracking form, develop resume packages of } \\
\text { external candidates that meet the job qualifications, promote } \\
\text { workforce diversity. }\end{array}$} \\
\hline $\begin{array}{l}\text { Represent company at job fairs } \\
.8 \mathrm{Ex} \\
.2 \mathrm{Nx}\end{array}$ & \multicolumn{2}{|c|}{$\begin{array}{l}\text { Identify appropriate representatives, supply literature, displays, } \\
\text { arrange appropriate shipping, transportation, etc. }\end{array}$} \\
\hline $\begin{array}{l}\text { Target \& schedule interviews at } \\
\text { colleges to promote workforce } \\
\text { diversity } \\
.2 \mathrm{Ex} \\
.3 \mathrm{Nx} \\
\end{array}$ & \multicolumn{2}{|c|}{$\begin{array}{l}\text { Analyze college curriculum, recruiting history, enrollments to } \\
\text { ident ify those that best supply WHC needs. Set interview dates, } \\
\text { identify WHC recruiters, provide necessary brochures, } \\
\text { correspondence, etc. }\end{array}$} \\
\hline $\begin{array}{l}\text { Insure employment coordination in } \\
\text { compliance with } 3161 \text { restructuring } \\
\text { requirements. } \\
.6 \mathrm{Nx} \\
.2 \mathrm{Ex}\end{array}$ & \multicolumn{2}{|c|}{$\begin{array}{l}\text { Provide information on all external positions and employees } \\
\text { affected by restructuring under } 3161 \text { to other DOE sites, gather } \\
\text { resumes, information on job openings from other DOE sites as } \\
\text { required by } 3161 \text {. }\end{array}$} \\
\hline
\end{tabular}

HR Central Services

Recruitment Page 24 


\begin{tabular}{|c|c|c|}
\hline 2.A.2 Description of Activities & $\begin{array}{l}\text { Westinghouse Hanford Company } \\
\text { HR Central Services } \\
\text { Recruitment } \\
\text { SMS/HBS No. } 6.10 \cdot 2 \cdot 3 \cdot 5 \\
\end{array}$ & $\begin{array}{l}\text { FY } 1995 \\
\text { Site Support Program Plan } \\
\text { Date Prepared: } 8 / 12 / 94\end{array}$ \\
\hline ACTIVITY & \multicolumn{2}{|c|}{ DESCRIPTION } \\
\hline $\begin{array}{c}\text { Devel op recruitment literature and } \\
\text { displays } \\
.3 \text { Ex }\end{array}$ & \multicolumn{2}{|c|}{$\begin{array}{l}\text { Develop concepts for literature/displays, provide copy, prepare } \\
\text { graphics, photographs, layout. Utilize appropriate internal and } \\
\text { external services final preparation and production of materiais. } \\
\text { Work with advertising agency as needed to develop and place } \\
\text { employment advertising. }\end{array}$} \\
\hline $\begin{array}{l}\text { Provide employee reassignment } \\
\text { assistance } \\
.3 \mathrm{Ex} \\
.3 \mathrm{Nx}\end{array}$ & \multicolumn{2}{|c|}{$\begin{array}{l}\text { Provide Job P1acement Assistance office services to assist in the } \\
\text { internal reassignment of excess WHC employees. Services include } \\
\text { individual counselling, resume preparation assistance, matching of } \\
\text { open positions and excess personnel, tracking of status/action for } \\
\text { each candidate and position, weekly status reports. }\end{array}$} \\
\hline $\begin{array}{l}\text { Assure surplus employee priority } \\
\text { consideration for open positions } \\
\text { and placement. } \\
.5 \mathrm{Nx} \\
.2 \mathrm{Ex}\end{array}$ & \multicolumn{2}{|c|}{$\begin{array}{l}\text { Post all external openings on the DOE JOBBS system, develop resume } \\
\text { packages for hiring managers containing resumes for those requiring } \\
\text { preferential consideration/hiring, track status maintain } \\
\text { documentation for audit purposes. }\end{array}$} \\
\hline & & \\
\hline & & \\
\hline
\end{tabular}




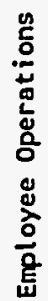




\begin{tabular}{|c|c|}
\hline 2.A.2 Description of Activities & $\begin{array}{l}\text { Westinghouse Hanford Company } \\
\text { HR Central Services } \\
\text { Employment Operations } \\
\text { SMS/WBS No. } 6.10 .2 .3 .4 \\
\end{array}$ \\
\hline ACTIVITY & DESCRIPTION \\
\hline Employment Operations & $\begin{array}{l}\text { Activities of the Employment/Employment Operations function } \\
\text { include: }\end{array}$ \\
\hline $1.0 \mathrm{Nx}$ & $\begin{array}{l}\text { Maintain/track resumes received which may be used for anticipated } \\
\text { skills requirements. } \\
\text { Forward resumes to BCSR for notification of receipt. } \\
\text { Develop an applicant pool for each validated open position. }\end{array}$ \\
\hline $1.5 \mathrm{Nx}$ & $\begin{array}{l}\text { Schedule interviews and coordinate interviews between divisions. } \\
\text { Administer contract agreement with Goodwill to compile Company } \\
\text { information for candidates interviewed. } \\
\text { Coordinate drug screening of applicants interviewed. } \\
\text { Administer contract agreement with Uniglobe for interviewee travel } \\
\text { arrangements. } \\
\text { Review and coordinate expense reports. } \\
\text { Coordinate with Travel and Transportation for relociation of new } \\
\text { employee. } \\
\text { Administer contract agreement with U.S. Suites for temporary living } \\
\text { accommodations for new employee. }\end{array}$ \\
\hline $3.0 \mathrm{Nx}$ & $\begin{array}{l}\text { Track applicants considered by hiring manager, applicants } \\
\text { interviewed, and candidate selected. } \\
\text { Ensure documentation of selection decision criteria (applicant } \\
\text { evaluation). } \\
\text { Coordinate pre-employment security investigation request for } \\
\text { selected candidate. } \\
\text { Coordinate with Compensation and hiring manager to develop offer } \\
\text { for selected candidate and present offer. } \\
\text { Schedule medical evaluation upon selected candidate's acceptance of } \\
\text { offer. }\end{array}$ \\
\hline $\begin{array}{r}.5 \mathrm{Ex} \\
1.0 \mathrm{Nx}\end{array}$ & $\begin{array}{l}\text { Maintain PTF follow system. } \\
\text { Provide headcount tracking reports. } \\
\text { Provide pipeline tracking report. }\end{array}$ \\
\hline
\end{tabular}




\begin{tabular}{|c|c|}
\hline 2.A.2 Description of Activities & $\begin{array}{l}\text { Hestinghouse Hanford Company } \\
\text { HR Central Services } \\
\text { Employment Operations } \\
\text { SMS/WBS No. } 6.10 .2 .3 .4 \\
\end{array}$ \\
\hline ACTIVITY & DESCRIPTION \\
\hline $1.0 \mathrm{Nx}$ & $\begin{array}{l}\text { Coordinate with HR Records to establish employee payroll number and } \\
\text { personnel file } \\
\text { Provide New Hire Orientation training and Benefits sign-on for WHC, } \\
\text { ICF KH, and BCSR employees. }\end{array}$ \\
\hline $1.0 \mathrm{Nx}$ & Comply with OFCCP, ADA, and EEO regulations. \\
\hline $1.0 \mathrm{Nx}$ & Coordinate student employment program hiring with EIP. \\
\hline Pre-employment Investigations & Activities of the Pre-employment Investigations include: \\
\hline $\begin{array}{r}2.0 \mathrm{Nx} \\
.5 \mathrm{Ex}\end{array}$ & $\begin{array}{l}\text { Receive requests for pre-employment investigations from WHC and } \\
\text { BCSR. } \\
\text { Initiate proper pre-employment investigations (new or update). } \\
\text { Maintain the pre-employment portion of the Clearance Process } \\
\text { Tracking System. } \\
\text { Coordinate the requests for a DOE Security Clearance between HR } \\
\text { Recruitment and Personne1 Security. } \\
\text { Issue weekly reports on the status of applicants pre-employment } \\
\text { investigations. } \\
\text { Resolve/act on derogatory information contained in the } \\
\text { investigations. } \\
\text { Maintain a close working relationship with WHC General Counse1. } \\
\text { Coordinate the badging of "new hires" between HR and Personnel } \\
\text { Security. } \\
\text { Maintain files on all WHC and BCSR "new hires". }\end{array}$ \\
\hline Posting Administration & Activities of the Posting Administration function include: \\
\hline
\end{tabular}




\begin{tabular}{|c|c|}
\hline 2.A.2 Description of Activities & $\begin{array}{c}\text { Hestinghouse Hanford Company } \\
\text { HR Central Services } \\
\text { Employment Operations } \\
\text { SMS/HBS No. } 6.10 .2 .3 .4 \\
\end{array}$ \\
\hline ACTIVITY & DESCRIPTION \\
\hline $\begin{array}{ll}2.0 & \mathrm{Nx} \\
2.0 \mathrm{Ex}\end{array}$ & $\begin{array}{l}\text { Initiate tracking of a11; requests for personnel (regular, } \\
\text { temporary, student, hourly, rotational, etc.) and provide expedited } \\
\text { processing. } \\
\text { Centralized ability to forecast and project hiring trends and to } \\
\text { produce reports which troubleshoot identified problem areas, such } \\
\text { as headcount and affirmative action applicant data (on posting } \\
\text { applicants). } \\
\text { Ensure fairness and consistency in filling open positions to deter } \\
\text { potential issues that lead to organizing efforts. } \\
\text { Post positions sitewide to provide ready access to applicant pools } \\
\text { across divisions. } \\
\text { Comply with HAMTc contractual agreement to post HAMTc positions } \\
\text { sitewide (transfer groups cross organizational boundaries). } \\
\text { Track employee posting applications forwarded to hiring manager, } \\
\text { applicants interviewed, and candidate selected. } \\
\text { Ensure documentation of selection decision criteria (applicant } \\
\text { evaluation). } \\
\text { Coordinate and follow up with compensation and hiring manager to } \\
\text { develop offer for selected candidate. } \\
\text { Schedule medical evaluation upon selected candidate's acceptance of } \\
\text { offer, if temporary applicant is selected. } \\
\text { Ensure legal forms are completed when employees cross companies } \\
\text { (Intellectual Property Agreement and Conflict of Interest } \\
\text { guestionnaire). } \\
\text { Review qualifications of posting employees. } \\
\text { Ensure a review for EEOC purposes. } \\
\text { Establish and administer the excess process (JPA0) } \\
\text { Establish and administer the recall Iist (as required). }\end{array}$ \\
\hline
\end{tabular}




\begin{tabular}{|c|c|}
\hline 2.A.2 Description of Activities & $\begin{array}{l}\text { Westinghouse Hanford Company } \\
\text { HR Central Services } \\
\text { Administrative Services } \\
\text { SMS/WBS No. } 6.10 .2 .3 .6 \\
\end{array}$ \\
\hline ACTIVITY & DESCRIPTION \\
\hline $\begin{array}{c}\text { Administer Hourly support services } \\
.8 \mathrm{Ex} \\
1.5 \mathrm{Nx}\end{array}$ & $\begin{array}{l}\text { Administer WHC Hourly Support Staff having specialized clerical, } \\
\text { secretarial, professiona1, escort and tour guide knowledge useful } \\
\text { to WHC and BCSR to respond to peak work Toads and specialized } \\
\text { program needs. }\end{array}$ \\
\hline $.5 \mathrm{Nx}$ & $\begin{array}{l}\text { Perform centralized scheduling of office support services "Hourly } \\
\text { personnel" serving WHC, BCSR, ICF KH and DOE programs. }\end{array}$ \\
\hline $\begin{array}{l}\text { Administer office support services } \\
1.0 \text { Ex }\end{array}$ & $\begin{array}{l}\text { Screen resumes/applications and schedule interviews to select } \\
\text { qual ified applicants for Hourly support service which is staffed } \\
\text { with clerks/secretaries with knowledge of basic office duties. } \\
\text { Assemble instruction manual for on-the-job training to indoctrinate } \\
\text { newly hired clerks with standard software and WHC procedures and } \\
\text { guidelines, i.e. internal/external letter, macros, cc:Mail, } \\
\text { Hanford, etc. }\end{array}$ \\
\hline $\begin{array}{l}2425 \text { building administrator } \\
.2 \mathrm{Ex} \\
1.0 \mathrm{Nx}\end{array}$ & $\begin{array}{l}\text { Responsibilities are: staffing receptionist desk, safety, security } \\
\text { of building, interface with Landlord, conference rooms, maintenance } \\
\text { of audio visual equipment, all building equipment, lunch room } \\
\text { facilities, etc. Interface with WHC Facilities group for building } \\
\text { modifications, maintenance and staffing. }\end{array}$ \\
\hline \multirow[t]{5}{*}{$\begin{array}{l}\text { Administer Human Reliability } \\
\text { program } \\
2.0 \mathrm{Ex} \\
.5 \mathrm{Nx}\end{array}$} & Act as direct interface with RL SAS, HRD and Procurement. \\
\hline & Act as primary interface with the Medical Review Office. \\
\hline & Maintain record of training, clinical test results and actions. \\
\hline & $\begin{array}{l}\text { Ensure that appropriate medical, psychological and drug tests are } \\
\text { conducted. }\end{array}$ \\
\hline & Coordinate and assist with employee and management training. \\
\hline
\end{tabular}

HR Central Services Administrative Services 


\begin{tabular}{|c|l|l|}
\hline 2.A.2 Description of Activities & \multicolumn{1}{|c|}{$\begin{array}{c}\text { Hestinghouse Hanford Company } \\
\text { AR Central Services } \\
\text { Administrative Services } \\
\text { SMS/HBS No. 6.10.2.3.6 }\end{array}$} & $\begin{array}{c}\text { FY 1995 } \\
\text { Site Support Program Plan } \\
\text { Date Prepared: 8/12/94 }\end{array}$ \\
\hline ACTIVITY & \multicolumn{1}{|c|}{ DESCRIPTION } \\
\hline & Provide oversight for the drug testing contract. \\
\hline & Evaluate the program annually and submit reports. \\
\hline & $\begin{array}{l}\text { Provide al1 employee awareness and education through a forma7 } \\
\text { communications plan. }\end{array}$ \\
\hline & Make recommendations on a17 PSAP positions. \\
\hline & Ensure that access authorization requirements are met. \\
\hline & Conduct weekly random drug testing. \\
\hline & \\
\hline & \\
\hline & \\
\hline & \\
\hline
\end{tabular}




\begin{tabular}{|c|c|c|c|c|c|c|c|c|}
\hline \multicolumn{4}{|c|}{ Full-Time Equivalent Staff by Job Description } & \multicolumn{5}{|c|}{ NOTE: Job Family Only After 1996} \\
\hline JoB Füili & $\therefore \because \cdots$ & $\therefore \because \vdots$ & $\because$ अ & किख & ise & ৪) & $2+3$ & अंख \\
\hline Job category & 1994 & 1995 & 1996 & 1997 & 1998 & 1999 & 2000 & 2001 \\
\hline MANAGERS $\quad \therefore$ & & & $\therefore$ & 80 & $\therefore 70$ & 7.0 & $8^{7}, 0$. & अ:०० \\
\hline \multicolumn{9}{|l|}{ First line } \\
\hline General/executive & & 7.0 & 7.0 & & & & & \\
\hline \multicolumn{9}{|l|}{ Project/Program } \\
\hline \multicolumn{9}{|l|}{ Other } \\
\hline \multicolumn{9}{|l|}{ ENGINEERS } \\
\hline \multicolumn{9}{|l|}{ Chemical } \\
\hline \multicolumn{9}{|l|}{ civil } \\
\hline \multicolumn{9}{|l|}{ Computer } \\
\hline \multicolumn{9}{|l|}{ Electrical } \\
\hline \multicolumn{9}{|l|}{ Environmental } \\
\hline \multicolumn{9}{|l|}{ Industrial } \\
\hline \multicolumn{9}{|l|}{ Mechanical } \\
\hline \multicolumn{9}{|l|}{ Nuclear } \\
\hline \multicolumn{9}{|l|}{ Petrol eum/Mining } \\
\hline \multicolumn{9}{|l|}{ Plant } \\
\hline \multicolumn{9}{|l|}{ Quality Control } \\
\hline \multicolumn{9}{|l|}{ Safety } \\
\hline Other & & & & 7 & & & & \\
\hline
\end{tabular}




\begin{tabular}{|c|c|c|c|c|c|c|c|c|}
\hline \multicolumn{4}{|c|}{ Ful1-Time Equivalent Staff by Job Description } & \multicolumn{5}{|c|}{ NOTE: Job Family Only After 1996} \\
\hline JOB FAMHLY & & $\because \because \because 3$ & खिए & अे & अभि & ख़ & अै? & ब्: \\
\hline Job category & 1994 & 1995 & 1996 & 1997 & 1998 & 1999 & 2000 & 2001 \\
\hline SCIENTISTS $\quad \because \quad \cdots \quad \cdots$ & & $\because \because 3$ & 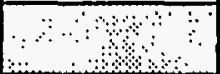 & : & $3 \cdot 3$ & $\sqrt{3}$ & 3 & $\therefore \because \because$ \\
\hline Chemists & & & & & & & & \\
\hline Environmental & & & & & & & & \\
\hline Geologists & & & & & & & & \\
\hline Life & & & & & & & & \\
\hline Material & & & & & & & & \\
\hline Mathematicians & & & & & & & & \\
\hline Physicists & & & & & & & & \\
\hline Social & & & & & & & & \\
\hline other & & & & & & . & & \\
\hline ADMIN/OTTHER PROFESSIONALS $: \ldots$ & & & . & 30.5 .3 & 30.5 & $30: 5$ & 30.5 & $30: 5$ \\
\hline Accountant/auditor & & & & & & & & \\
\hline Architect & & & & & & & & \\
\hline Buyers/procurement & & & & & & & & \\
\hline Communications & & & & & & & & \\
\hline Compl iance inspectors & & & & & & & & \\
\hline Computer System Anal & & & & & & & & \\
\hline Cost Est/planner/sch & & & & & & & & \\
\hline Health Physics & & & & & & & & \\
\hline
\end{tabular}




\begin{tabular}{|c|c|c|c|c|c|c|c|c|}
\hline \multicolumn{4}{|c|}{ Ful1-Time Equivalent Staff by Job Description } & \multicolumn{5}{|c|}{ NOTE: Job Family Only After 1996} \\
\hline SOB FAMUYY & $\because \quad \because \cdots$ & \& & ४ै। & ४ै। & ब. & अे। & अे+ि & में \\
\hline Job category & 1994 & 1995 & 1996 & 1997 & 1998 & 1999 & 2000 & 2001 \\
\hline Industrial Hygiene & & & & & & & & \\
\hline Lawyers & & & & & & & & \\
\hline Personnel/Labor Rela & & 30.5 & 30.5 & & & & & \\
\hline Physicians & & & & & & & & \\
\hline Physician Assis/Nurs & & & & & & & & \\
\hline Safeguard \& Security & & & & & & & & \\
\hline Tech Writers \& Edit & . & & & & & & & \\
\hline Trainers & & & & & & & & \\
\hline other & & & & & & & & \\
\hline JOB FAMILY $: \quad \cdot \quad: \quad$ & & & . & $\because$ & ४ & क्ष & : $:$ & -3ि: \\
\hline Job category & & & & & & & & \\
\hline GEH ADM/SECRETARY/CLERK & $\because$ & ? & & 35.0 & 3500 & 35.0 .3 & $335 \%$ & 35.03 \\
\hline Admin Assistants & & & & & & & & \\
\hline office Clerks (Gen) & & & & & & & & \\
\hline Office Clerks (Special) & & 22.0 & 22.0 & & & & & \\
\hline Secretaries & & 7.0 & 7.0 & & & & & \\
\hline Typist/Word Process & & & & & & & & \\
\hline Other Temporary & & 6.0 & 6.0 & & & & & \\
\hline TECHNICIANS & & & & & & & & \\
\hline
\end{tabular}




\section{HR CENTRAL SERVICES}

FORM 2.C.3 FTES

\begin{tabular}{|c|c|c|c|c|c|c|c|c|}
\hline \multicolumn{4}{|c|}{ Ful1-Time Equivalent Staff by Job Description } & \multicolumn{5}{|c|}{ NOTE: Job Family Only After 1996} \\
\hline JOB FAMI $\angle$ S & $\because \quad \therefore \quad \because \vdots$ & : & +ా & +ै.?: & अै। & +ि? & ४ै। & बि: \\
\hline Job category & 1994 & 1995 & 1996 & 1997 & 1998 & 1999 & 2000 & 2001 \\
\hline Computer Oper/Coder & & & & & & & & \\
\hline Drafters & & & & & & & & \\
\hline Engrs/Tech & & & & & & & & \\
\hline Envir. Sci Technicians & & & & & & & & \\
\hline Heal th Phys. Technic. & & & & & & & & \\
\hline Indus. Saf/Heal th Tech & & & & & . & & & \\
\hline Instru/Control Tech & & & & & & & & \\
\hline Lab. Technicians & & & & & & & & \\
\hline Media Technicians & & & & & & & & \\
\hline Survey/Map Tech & & & & & & & & \\
\hline other & & & & & & & & \\
\hline $\begin{array}{llll}\text { CRAFTS } & \cdots & \cdots \\
\end{array}$ & & & $\therefore$ & $\cdots$ & अa & - & अै: & ?: \\
\hline Carpenters & & & & & & & & \\
\hline Electricians & & & & & & & & \\
\hline HVAC & & & & & & & & \\
\hline Machinists & & & & & & & & \\
\hline Masons & & & & & & & & \\
\hline Millwrights & & & & & & & & \\
\hline Painters & & & & & & & & \\
\hline
\end{tabular}




\begin{tabular}{|c|c|c|c|c|c|c|c|c|}
\hline \multicolumn{4}{|c|}{ Ful1-Time Equivalent Staff by Job Description } & \multicolumn{5}{|c|}{ NOTE: Job Family Only After 1996} \\
\hline JOB FAMML & & $\because$ & अथ & खै? & आ & s. & + & 8 \\
\hline Job category & 1994 & 1995 & 1996 & 1997 & 1998 & 1999 & 2000 & 2001 \\
\hline Plumbers/Pipefitter & & & & & & & & \\
\hline Struct/Metal Horker & & & & & & & & \\
\hline Vehic./Mob Equip Me & & & & & & & & \\
\hline Welders & & & & & & & & \\
\hline other & & & & & & & & \\
\hline OPERATORS & & $\therefore \cdot \quad \therefore$ & a & $\therefore$ & $\because: \because$ & 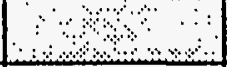 & $2+3$ & ४४ \\
\hline Chemical System & & & & & & & & \\
\hline Drillers & & & & & & & & \\
\hline Lt. Vehicle Drivers & & & & & & & & \\
\hline Material Moving Equ & & & & & & & & \\
\hline Nuclear Plant & & & & & & & & \\
\hline Utilities Waste Pro & & & & & & & & \\
\hline other & & & & & & & & \\
\hline LABOÓR \& GEN WORKERS & & & & & $\%$ & अ & । & \\
\hline Firefighters & & & & & $\cdot$ & & & \\
\hline Food Service & & & & & & & & \\
\hline Hand/Help Lab Gen & & & & & & & & \\
\hline Hand/Help Lab Spec & & & & & & & & \\
\hline Jani tors/Cleaners & & & & & & & & \\
\hline
\end{tabular}


HR CENTRAL SERVICES

FORM 2.C.3 FTES

WBS Number 6.10.2.3

FY 1995 SSPP

\begin{tabular}{|c|c|c|c|c|c|c|c|c|}
\hline \multicolumn{4}{|c|}{ Ful1-Time Equivalent Staff by Job Description } & \multicolumn{5}{|c|}{ NOTE: Job Family Only After 1996} \\
\hline JOB FAMILY & & $\because \cdots$ & s) & अें & अध्य & ৪৷ & १ै। & 18 \\
\hline Job category & 1994 & 1995 & 1996 & 1997 & 1998 & 1999 & 2000 & 2001 \\
\hline \multicolumn{9}{|l|}{ Laundry Horkers } \\
\hline \multicolumn{9}{|l|}{ Security Guards } \\
\hline \multicolumn{9}{|l|}{ other } \\
\hline TOTAL & * $\quad 80.2$ & 72.5 & 72.5 & 72.5 & 72.5 & 72.5 & 72.5 & 72.5 \\
\hline
\end{tabular}

* Approved 1994 Fiscal Year Work Plan 


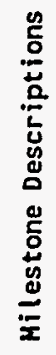

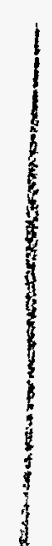




\section{Westinghouse Hanford Company MILESTONE DESCRIPTION SHEET}

3: i repare action plan based on results of application of the environmental workforce transition model.

Assigned To:

G. L. Clogston/L. L. Myers

Program WBS Designator:

Due Date:

6.10 .2 .3

$01 / 17 / 95$

Control Number: FAH-95-001

MILESTONE TYPE:
$\square$ DOE-HO
X DOE-RL
$\square$ CNTR
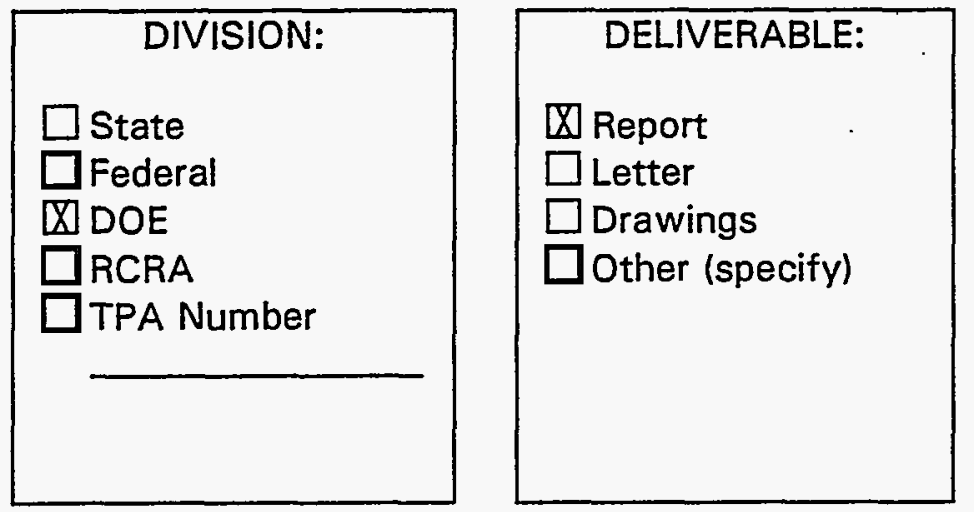

Rev.:

Milestone description:

The Department of Energy, Richland will provide a software tool called Workforce Transition Model which will identify the delta between the current workforce and the future requirements. Human Resources will be required to prepare an action plan to identify how the workforce will be transitioned.

Ex $\quad .25$

Description of what constitutes completion of this milestone:

The action plan will be a report identifying plans to enable the workforce changes

The January 17, 1995 completion date is contingent upon reciept of the $\mathrm{RL}$ generated Workforce strategies output from the "Workforce Transition Model" by December 1, 1994.

\begin{tabular}{|c|c|c|c|}
\hline $\begin{array}{l}\text { rost Account Manager } \\
\text { L. Clogston }\end{array}$ & Date & $\begin{array}{l}\text { Program/Project Manager } \\
\text { L. L. Myers }\end{array}$ & Date \\
\hline Program Element Manager & Date & $\begin{array}{l}\text { DOE Monitor } \\
\text { S. A. Hostick }\end{array}$ & Date \\
\hline
\end{tabular}




\section{Westinghouse Hanford Company \\ MILESTONE DESCRIPTION SHEET}

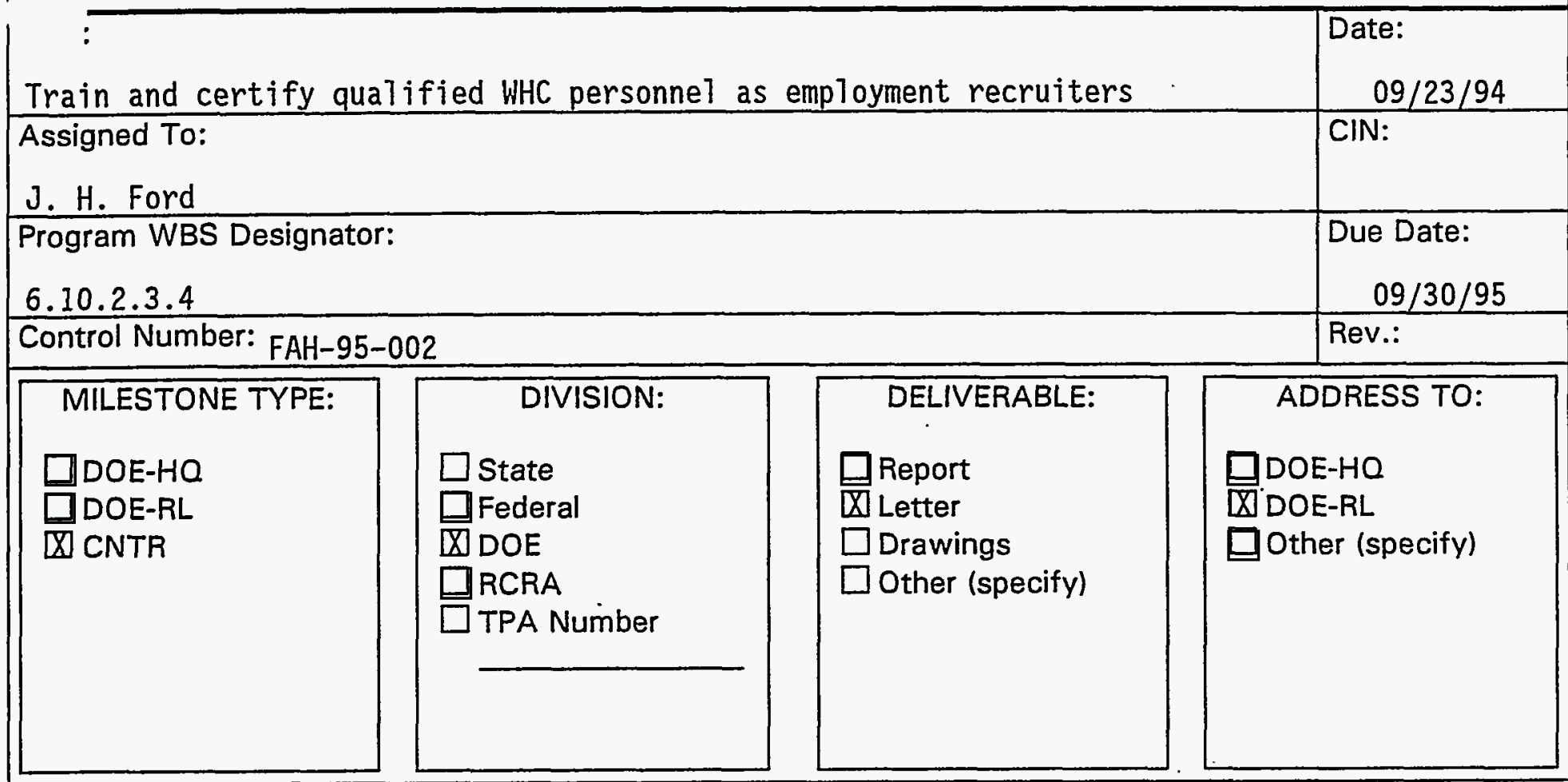

Milestone description:

Prepare class agenda, train and certify WHC managers and select exempt

personnel to provide offsite recruitment for WHC employment needs.

Ex $\quad .2$

Description of what constitutes completion of this milestone:

Training schedule will be established and provided to RL by September 30, 1995. A record of the managers trained will be provided periodically until

conclusion.

st Accounț Manager

Date

Program/Project Manager

Date

W. L. Clogston

L. L. Myers

Program Element Manager

Date

DOE Monitor

Date

S. A. Hostick 


\section{Westinghouse Hanford Company \\ MILESTONE DESCRIPTION SHEET}

:

ie:

:

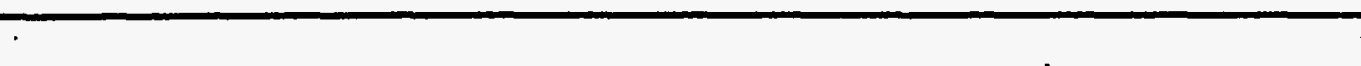

Implement applicant tracking module of PeopleSOFT

Assigned To:

D. E. Hansen

Program WBS Designator:

Due Date:

$6 \cdot 10 \cdot 2 \cdot 3.3$

$03 / 01 / 95$

Control Number: FAH-95-003

\begin{tabular}{|c|c|c|c|}
\hline $\begin{array}{l}\text { MILESTONE TYPE: } \\
\square \text { DOE-HO } \\
\square \text { DOE-RL } \\
\square \text { CNTR }\end{array}$ & $\begin{array}{l}\text { DIVISION: } \\
\square \text { State } \\
\square \text { Federal } \\
\square \text { DOE } \\
\square \text { RCRA } \\
\square \text { TPA Number }\end{array}$ & $\begin{array}{l}\text { DELIVERABLE: } \\
\square \text { Report } \\
\square \text { Letter } \\
\square \text { Drawings } \\
\square \text { Other (specify) }\end{array}$ & $\begin{array}{l}\text { ADDRESS TO: } \\
\square \text { DOE-HO } \\
\square \text { DOE-RL } \\
\square \text { Other (specify) }\end{array}$ \\
\hline
\end{tabular}

Milestone description:

Implement the PeopleSOFT applicant tracking module to track employment

applicants.

Ex $\quad .8$

Description of what constitutes completion of this milestone:

Discarding HRAT tracking system for current applicants and begin to utilize

PeopleSOFT.

st Account Manager

Date

Program/Project Manager

Date

L. L. Clogston

L. L. Myers

Program Element Manager

Date

DOE Monitor

Date

S. A. Hostick 


\section{Westinghouse Hanford Company \\ MILESTONE DESCRIPTION SHEET}

$;$

:

Date:

Prioritization for integration of Human Resources PeopleSOFT elements

Assigned To:

D. E. Hansen

Program WBS Designator:

6.10.2.3.3

Control Number: FAH-95-004

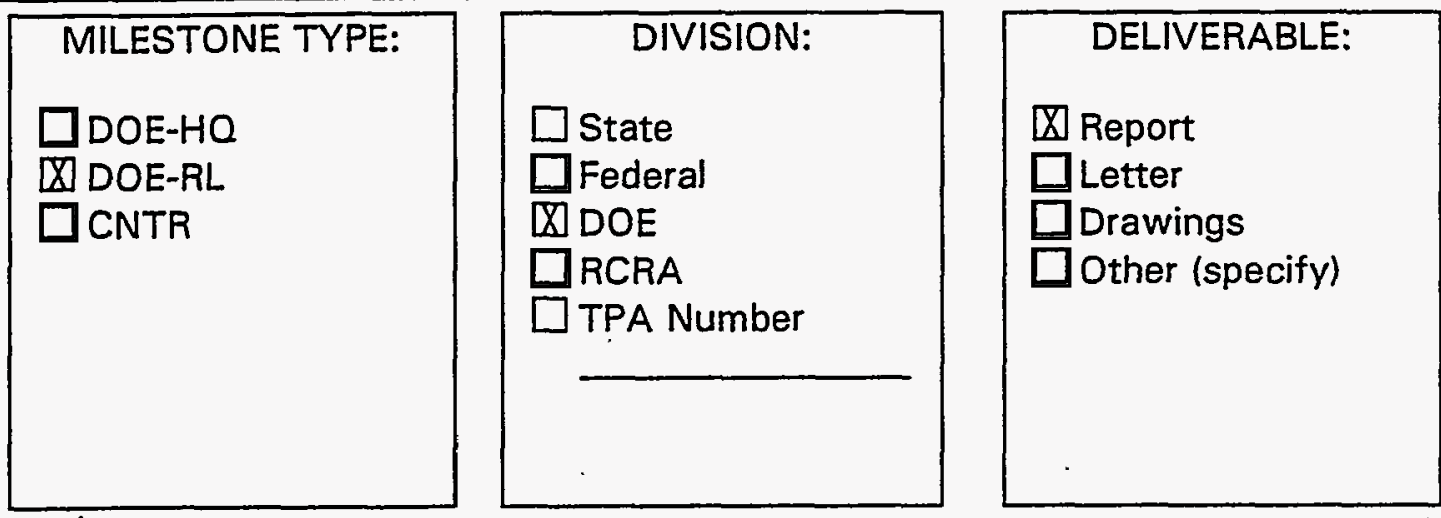

$09 / 23 / 94$

CIN:

Due Date:

$1 / 01 / 95$

Rev.:

Milestone description:

PeopleSOFT is a software purchased to integrate over 60 Human Resources mechanized and manual systems. Due to the changes since beginning the analysis, priorities must be re established for implementing various Human Resource modules. Employee core data is first, applicant tracking second. A priority list will be developed to determine successive as well as possible concurrent implementation of other modules.

Ex $\quad .4$

Description of what constitutes completion of this milestone:

A list of planned module implementation priorities. This will include additional modules which were unknown at the beginning of this multi-year project.

\begin{tabular}{|c|c|c|c|}
\hline $\begin{array}{l}\text { rist Account Manager } \\
\text { L. Clogston }\end{array}$ & Date & $\begin{array}{l}\text { Program/Project Manager } \\
\text { L. L. Myers }\end{array}$ & Date \\
\hline $\begin{array}{l}\text { Program Element Manager } \\
\text {. }\end{array}$ & Date & $\begin{array}{l}\text { DOE Monitor } \\
\text { S. A. Hostick }\end{array}$ & Date \\
\hline
\end{tabular}




\section{Westinghouse Hanford Company \\ MILESTONE DESCRIPTION SHEET}

cle:

Participate in salary surveys for Cy96 salary planning

Date:

Assigned To:

$09 / 23 / 94$

CIN:

R. G. Joseph

Program WBS Designator:

Due Date:

6.10 .2 .3 .1

$08 / 01 / 95$

Control Number: FAH-95-005

MILESTONE TYPE:
$\square$ DOE-HQ
冈 DOE-RL
$\square$ CNTR

\begin{tabular}{|l|}
\hline \multicolumn{1}{|c|}{ DIVISION: } \\
$\square$ State \\
$\square$ Federal \\
$\square$ DOE \\
$\square$ RCRA \\
$\square$ TPA Number \\
\hline
\end{tabular}

Rev.:

Milestone description:

Participate in salary surveys to determine the Company's salary position to

the external market. This information is used in the Company's salary

Increase Fund Request.

Ex $\quad .2$

Description of what constitutes completion of this milestone:

A Tetter to RL listing surveys in which the Company has participated.

st Account Manager

G. L. Clogston

Program Element Manager
Date

DELIVERABLE:
$\square$ Report
$\square$ Letter
$\square$ Drawings
$\square$ Other (specify)

ADDRESS TO:

$\square$ DOE-HO

X DOE-RL

$\square$ Other (specify)

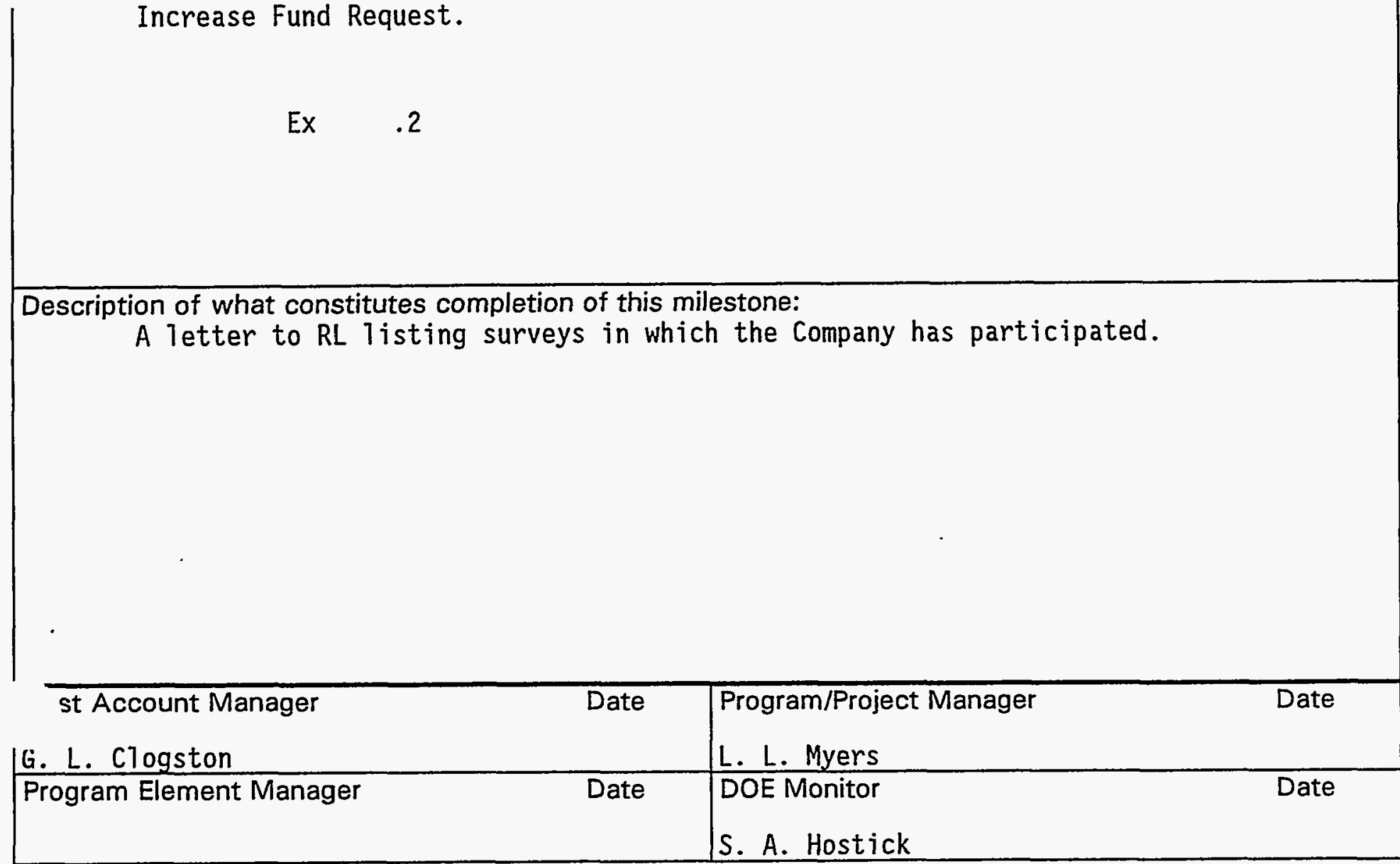




\section{Westinghouse Hanford Company \\ MILESTONE DESCRIPTION SHEET}

\begin{tabular}{l|l|l|}
\hline 3: & Date:
\end{tabular}

Submit CY 96 Salary Increase Fund Requests

Assigned To:

$09 / 23 / 94$

CIN:

R. G. Joseph

Program WBS Designator:

Due Date:

6.10 .2 .3 .1

$09 / 30 / 95$

Control Number: FAH-95-006

\begin{tabular}{|c|c|c|c|}
\hline MILESTONE TYPE: & DIVISION: & DELIVERABLE: & ADDRESS TO: \\
\hline $\begin{array}{l}\square \text { DOE-HQ } \\
\square \text { DOE-RL } \\
\square \text { CNTR }\end{array}$ & $\begin{array}{l}\square \text { State } \\
\square \text { Federal } \\
\square \text { DOE } \\
\square \text { RCRA } \\
\square \text { TPA Number }\end{array}$ & $\begin{array}{l}\square \text { Report } \\
\square \text { Letter } \\
\square \text { Drawings } \\
\square \text { Other (specify.) }\end{array}$ & $\begin{array}{l}\square \text { DOE-HQ } \\
\text { X DOE-RL } \\
\square \text { Other (specify) }\end{array}$ \\
\hline
\end{tabular}

Milestone description:

Prepare and submit request to the Department of Energy, Richland for merit, promotion and adjustment funds for al7 non-bargaining WHC, BCSR and ICF KH employees.

Ex $\quad .25$

Description of what constitutes completion of this milestone:

A report with supporting documentation, delivered to the RL.

\begin{tabular}{|c|c|c|c|}
\hline $\begin{array}{l}\text { onst Account Manager } \\
\therefore \text { L. Clogston }\end{array}$ & Date & $\begin{array}{l}\text { Program/Project Manager } \\
\text { L. L. Myers }\end{array}$ & Date \\
\hline Program Element Manager & Date & $\begin{array}{l}\text { DOE Monitor } \\
\text { S. A. Hostick }\end{array}$ & Date \\
\hline
\end{tabular}




\section{Westinghouse Hanford Company \\ MILESTONE DESCRIPTION SHEET}

e:

Establish Worker's Compensation cost baseline

Assigned To:

R. G. Joseph

Program WBS Designator:

Due Date:

6.10 .2 .3 .1

$04 / 01 / 95$

Control Number: FAH-95-007

\begin{tabular}{|l|l|}
\hline MILESTONE TYPE: \\
$\square$ DOE-HO \\
囚 DOE-RL \\
$\square$ CNTR
\end{tabular} \mid $\begin{aligned} & \square \text { DIVISION: } \\
& \square \text { State } \\
& \square \text { Dederal } \\
& \square \text { RCRA } \\
& \square \text { TPA Number } \\
& \\
& \end{aligned}$

Rev.:

Milestone description:

Gather statistics on a quarteriy basis depicting the Washington State

Department of Labor and Industries payments for medical and disability

claims costs as well as the Company's differential.

Ex .3

Description of what constitutes completion of this milestone:

A report along with supporting charts.

\begin{tabular}{|c|c|c|c|}
\hline $\begin{array}{l}\text { ast Account Manager } \\
: \text { L. Clogston }\end{array}$ & Date & $\begin{array}{l}\text { Program/Project Manager } \\
\text { L. L. Myers }\end{array}$ & Date \\
\hline Program Element Manager & Date & $\begin{array}{l}\text { DOE Monitor } \\
\text { S. A. Hostick }\end{array}$ & Date \\
\hline
\end{tabular}




\section{Westinghouse Hanford Company \\ MILESTONE DESCRIPTION SHEET}

e:

\begin{tabular}{l|l}
\hline & Date:
\end{tabular}

$5 \%$ reduction in employment cycle time

Assigned To:

$09 / 23 / 94$

CIN:

J. T. Carello

Program WBS Designator:

Due Date:

$6.10 .2 \cdot 3.5$

$9 / 30 / 95$

Control Number: FAH-95-008

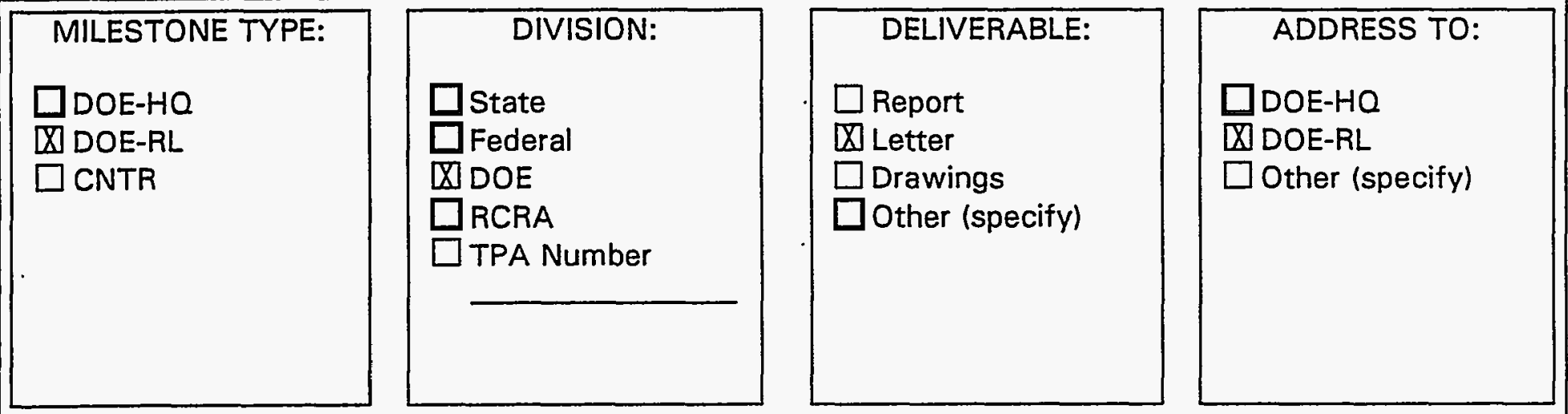

Milestone description:

Formally address elapsed days beginning with Employment's receipt of a

Position Tracking form, and ending when the position is filled.

Ex $\quad 1.0$

Description of what constitutes completion of this milestone:

A decrease in the elapsed time it takes to fill an open position which has

been identified by a Positịon Tracking Form.

st Account Manager

u. L. Clogston

Program Element Manager
Date

Date
Program/Project Manager

L. L. Myers

DOE Monitor

S. A. Hostick
Date

Date 


\section{Westinghouse Hanford Company \\ MILESTONE DESCRIPTION SHEET}

e:

cvaiuate potential to outsource employee. and retiree benefits enrollment processes.

Assigned To:

Date:

J. R. Sorensen

Program WBS Designator:

6.10.2.3.2

Control Number: FAH-95-009

\begin{tabular}{|c|c|c|}
\hline $\begin{array}{l}\text { MILESTONE TYPE: } \\
\square \text { DOE-HO } \\
\square \text { DOE-RL } \\
\square \text { CNTR }\end{array}$ & $\begin{array}{l}\text { DIVISION: } \\
\square \text { State } \\
\square \text { Federal } \\
\square \text { DOE } \\
\square \text { RCRA } \\
\square \text { TPA Number }\end{array}$ & $\begin{array}{l}\text { DELIVERABLE: } \\
\square \text { Report } \\
\square] \text { Letter } \\
\square \text { Drawings } \\
\square \text { Other (specify) }\end{array}$ \\
\hline
\end{tabular}

$09 / 23 / 94$

CIN:

Due Date:

$04 / 01 / 95$

Rev.:

Milestone description:

Evaluate the use of external services to provide mechanism to design and operate a system to collect employee/retiree enrollment choices and transmit appropriate data to the Company.

Ex .3

Description of what constitutes completion of this milestone:

An evaluation report of systems available with related cost estimates will

be prepared.

רast Account Manager

Date

Program/Project Manager

Date

L. Clogston

Program Element Manager

L. L. Myers

Date

DOE Monitor

Date

S. A. Hostick 


\section{Westinghouse Hanford Company \\ MILESTONE DESCRIPTION SHEET}

з:

Date:

Implement first phase of modified retiree health insurance program.

$09 / 23 / 94$

Assigned To:

J. R. Sorensen

Program WBS Designator:

$6.10 .2 \cdot 3.2$

Control Number: FAH-95-010

MILESTONE TYPE:
$\square$ DOE-HO
$\square$ DOE-RL
$\square$ CNTR

\begin{tabular}{|l|}
\hline \multicolumn{1}{|c|}{ DIVISION: } \\
$\square$ State \\
$\square$ Federal \\
$\square$ DOE \\
$\square$ RCRA \\
$\square$ TPA Number \\
\hline \\
\hline
\end{tabular}

\begin{tabular}{|l} 
DELIVERABLE: \\
$\square$ Report \\
$\square$ Letter \\
$\square$ Drawings \\
$\square$ Other (specify)
\end{tabular}

CIN:

Due Date:

$07 / 01 / 95$

Rev.:

Milestone description:

Medical insurance provided to retirees is being evaluated in 1994 and

recommendations developed for a phased-in process to change the program to:

1. Ensure cost effectiveness

2. Increase retiree share of cost

3. Improve efficiency of retiree program by reducing variations in coverage and retiree cost share which are the results of a history of multiple contractors.

$\begin{array}{ll}\text { Ex } & .25 \\ \mathrm{NX} & .20\end{array}$

Description of what constitutes completion of this milestone:

A communication to affected retirees regarding the program plus

communication to active employees regarding changes to program as it applies

to future retirees.

rost Account Manager

Date

Program/Project Manager

Date

L. Clogston

L. L. Myers

Program Element Manager

Date

DOE Monitor

Date

S. A. Hostick 


\section{Westinghouse Hanford Company \\ MILESTONE DESCRIPTION SHEET}

e: rrepare annual update of Health Benefits Utilization/Cost Review to include 1994 experience.

Assigned To:

J. R. Sorensen

Program WBS Designator:

6.10 .2 .3 .2

Control Number: FAH-95-011

\begin{tabular}{|c|c|c|c|}
\hline $\begin{array}{l}\text { MILESTONE TYPE: } \\
\square \text { DOE-HO } \\
\text { 囚DOE-RL } \\
\square \text { CNTR }\end{array}$ & $\begin{aligned} & \text { DIVISION: } \\
& \square \text { State } \\
& \square \text { Federal } \\
& \text { XDOE } \\
& \square \text { RCRA } \\
& \square \text { TPA Number }\end{aligned}$ & $\begin{array}{l}\text { DELIVERABLE: } \\
\text { 囚 Report } \\
\square \text { Letter } \\
\square \text { Drawings } \\
\square \text { Other (specify) }\end{array}$ & $\begin{array}{l}\text { ADDRESS TO: } \\
\square \text { DOE-HO } \\
\text { X DOE-RL } \\
\square \text { Other (specify) }\end{array}$ \\
\hline
\end{tabular}

Milestone description:

A summary of health care costs and experience for 1992/1993 was prepared in

1994. The 1995 report wi17 gather and analyze similar data for 1994,

comparing with earlier experience and with insurance company norms.

$\begin{array}{ll}\text { Ex } & .25 \\ \mathrm{Nx} & .10\end{array}$

Description of what constitutes completion of this milestone:

A 1995 Plan Design Analys is will be prepared and data will be analyzed

together with the 1994 report to identify high cost areas, trends, etc.

\begin{tabular}{|c|c|c|c|}
\hline $\begin{array}{l}\text { anst Account Manager } \\
\text { L. Clogston }\end{array}$ & Date & $\begin{array}{l}\text { Program/Project Manager } \\
\text { L. L. Myers }\end{array}$ & Date \\
\hline Program Element Manager & Date & $\begin{array}{l}\text { DOE Monitor } \\
\text { S. A. Hostick }\end{array}$ & $\overline{\text { Date }}$ \\
\hline
\end{tabular}




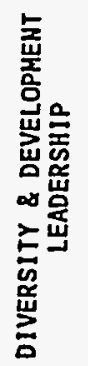




\begin{tabular}{|l|c|c|}
\hline 1.A Vision/Mission & $\begin{array}{c}\text { Westinghouse Hanford Company } \\
\text { Diversity \& Development } \\
\text { SMS/WBS No. 6.10.2.4 }\end{array}$ & $\begin{array}{c}\text { FY 1995 } \\
\text { Site Support Program Plan } \\
\text { Date Prepared: 8/12/94 }\end{array}$ \\
\hline
\end{tabular}

\section{VISION/MISSION}

To provide the resources and services to create an inclusive work environment that enhances our business performance and technical leadership. 


\section{PRIMARY CUSTOMERS}

The Department of Energy, Richland Operations Office (RL)

Westinghouse Hanford Company (WHC) - Management and Employees

Westinghouse Electric Corp. (WEC) - Government and Environmental Services Company (GESCO)

Taxpayers

\section{PRODUCTS/SERVICES PROVIDED}

Affirmative Action Plans (AAP) for WHC and BCS Richland (BCSR).

Resolution of internal complaints and external charges of discrimination.

Provide training on Equal Employment Opportunity (EEO), Affirmative Action (AA), Employee Assistance Program (EAP), sexual harassment and other diversity related subjects.

Conduct periodic internal assessments of a11 personnel activities (hires, terminations, promotions, training, etc., to assure there is no adverse impact on minorities and women.

Provide assessment and referral of employees with personal issues to appropriate resources.

Identify appropriate resources and services for employees, organizations and projects at all levels that are consistent with Company objectives.

Manage internal and external total quality resources and activities to meet the customers' needs.

Address specific organizational needs which will lead to total performance leadership.

Conduct organizational needs assessments.

Provide Hanford-wide professional development services at RL direction.

Provide organization and team development services including evaluation and follow up. 


\section{PRODUCTS/SERVICES PROVIDED (continued)}

Conduct classroom-delivered courses resulting from direction by RL or WHC.

Assess and design inter- and intra-organization development strategies, including goal setting and group/team development.

Develop curriculums targeted to improve knowledge, skills and abilities of specific job categories.

\section{MAJOR ACTIVITIES PERFORMED TO DELIVER-PRODUCTS AND SERVICES}

Interface regularly with management, employees and other Company organizations (Employee Concerns, Staff Relations, etc).

Support the periodic audit of Company AAPs by the Department of Labor - Office of Federal Contract Comp 7 iance Programs.

Monitor implementation of AAPs including regular reports to management and ad hoc reports as requested by WHC management, RL and WEC.

Interface as required with Equal Employment Office Commission (EEOC) and Washington State Human Rights Commission (WSHRC) investigators.

Provide support for site-wide diversity recognition activities in conjunction with other Hanford contractors and RL.

Prepare and implement $\mathrm{plans}$ for organizational needs assessments.

Interface regularly with RL Total Quality office.

Participating membership on the Hanford Quality Integration Team.

Attend regularly the Training And Data Exchange (TRADE) conferences.

Manage vendor-provided professional and organization development resources.

Manage contracts with vendor-provided total quality services. 


\section{MAJOR ACTIVITIES PERFORMED TO DELIVERY PRODUCTS AND SERVICES (continued)}

Serve as member and complete actions identified of DOE-sponsored Training Resource And Data Exchange (TRADE) Special Interest Group.

Participate on RL directed task team for development of facilitator cadre' for Hanford.

Design and develop "training" resulting needs assessments, from external audit findings, other services.

Design and implement curriculums for targeted categories of employees.

Design and distribute material and information which replaces classroom training.

Implement actions resulting from participation on DOE directed Hanford task teams and committees.

Generate special surveys and reports as directed by WHC management, RL, and Westinghouse Electric.

Participate as a member of the Hanford Training Council.

\section{EVALUATION OF MAJOR ACTIVITIES (COST, VALUE-ADDED, ETC.)}

The rotation development concept allows the broadening of the employee's experience base to be accelerated. A targeted internal rotation development program will allow the company to assist in preparing current employees in meeting their career goals and meet business needs at the same time. Specifically, developing current employees will reduce the cost associated with recruitment in some cases.

The education reimbursement program allows the Company to develop the talent and knowledge required to complete our mission with existing or reduced workforce.

Organization development improves the productivity and effectiveness of organizations, teams and individuals. This is increasing in importance as we downsize and reorganize the site.

Professional development resources improve or develop knowledge, skills and abilities of employees so that they can perform quality work safely and as a valued member of the team. 
EVALUATION OF MAJOR ACTIVITIES (COST, VALUE-ADDED, ETC.) (continued)

Supporting Hanford-wide activities provides integration and consistency of thought, but removes significant resources from program-directed work.

Compliance activities - development of AAPs are mandated by law. Complaint resolution efforts help to avoid costs that would be incurred in defending discrimination charges against the company.

Diversity strategy implementation - successful integration of the concept of diversity throughout the Company provides for improved recruitment and retention of a diverse workforce.

Employee assistance program - improves productivity of employees by assisting them to resolve personal issues that affect job performance.

\section{FACTORS WHICH INFLUENCE RESOURCE CONSUMPTION (CHANGES TO COST AND VOLUME)}

Alignment of staff with projects changes the nature of the work from focusing on Company-wide issues to project-wide issues.

Requests from RL are more Hanford-wide in nature and are continually evolving.

Significant reductions in external hiring will result in the need to provide new development opportunities in order to prepare current employees for future needs.

\section{FACTORS THAT INFLUENCE CHANGES IN TYPES OR NATURE OF PRODUCTS and SERVICES}

Staff downsizing sitewide will create a need to apply current program services beyond recent graduates into the existing professional employee population.

Specific program alignment of support services may influence program changes. As the program/project organizations push to align their support services, a decentratized program approach may occur.

Declining budgets accelerate the momentum to transition a significant pool of resources to the community. 


$\left[\begin{array}{cc|c|c}\hline \text { 1.B.2 External Assessment Summary } & \begin{array}{c}\text { Westinghouse Hanford Company } \\ \text { Diversity \& Development } \\ \text { SMS/WBS No. 6.10.2.4 }\end{array} & \begin{array}{c}\text { FY 1995 } \\ \text { Site Support Program P1an } \\ \text { Date Prepared: } 8 / 12 / 94\end{array} \\ \hline\end{array}\right.$

\section{OTHER EXTERNAL CHALLENGES}

Internal WHC and external RL organizational changes impact the effectiveness of maintaining clear 7 ines of communication. 


\section{GOALS AND OBJECTIVES}

Develop and administer Affirmative Action Plans.

Assist management and employees to identify and resolve personal issues that affect job performance.

Identify and implement initiatives that move the Company beyond compliance to a more inclusive concept of diversity.

Administer the registration of professional development activities, including seminar attendance and tuition reimbursement.

Prepare a Company-wide succession planning process.

Develop career management resources for WHC employees.

Provide management and professional development resources and services for each project/program area.

Coordinate the use of onsite and offsite professional deveiopment resources to meet the needs of WHC and RL.

Enable organizations to develop effective customer and team interface strategies.

Design and consult on organizational change projects to enhance the performance of the organization.

Provide direct support to managers and employees seeking to resolve discrimination issues.

Develop rotation development process for current employees. 


\begin{tabular}{|c|c|c|}
\hline & $\begin{array}{c}\text { Westinghouse Hanford Company } \\
\text { Diversity \& Development } \\
\text { SMS/WBS No. 6.10.2.4 }\end{array}$ & $\begin{array}{c}\text { FY 1995 } \\
\text { Site Support Program Plan } \\
\text { Date Prepared: 8/12/94 }\end{array}$ \\
\hline
\end{tabular}

\section{ASSUMPTIONS}

A11 members of management support EEO, AA and diversity plans and goals.

Displaced or excessed employees will satisfy some staffing needs and there will be no increase in regular staffing levels.

WHC total performance leadership will be congruent with The Secretary's Total Quality Plan. 


$\left[\begin{array}{c|c|c}\hline & \begin{array}{c}\text { Hestinghouse Hanford Company } \\ \text { Diversity \& Development } \\ \text { SMS/WBS No. 6.10.2.4 }\end{array} & \begin{array}{c}\text { FY 1995 } \\ \text { Site Support Program P1an } \\ \text { Date Prepared: } 8 / 12 / 94\end{array} \\ \hline\end{array}\right.$

\section{ISSUES AND CONSTRAINTS}

Impact of WHC/ICF KH integration is not yet known.

Impacts of BHI contract are not yet known.

Staff downsizing impacts are unknown.

Actions from Hanford Quality Integration Committee are not yet known.

Configuration of HR organization is still evolving. 


\begin{tabular}{c|c|c}
\hline 1.G Performance Measures & $\begin{array}{c}\text { Westinghouse Hanford Company } \\
\text { Diversity \& Development } \\
\text { SHS/WBS No. 6.10.2.4 }\end{array}$ & $\begin{array}{c}\text { FY 1995 } \\
\text { Site Support Program Plan } \\
\text { Date Prepared 8/12/94 }\end{array}$ \\
\hline
\end{tabular}

\section{PERFORMANCE MEASURES}

Our performance can be measured in two ways:

1. As an integral part of the project plans that we support and,

2. by the completion of our milestones. 
co 


\begin{tabular}{|c|c|c|}
\hline 2.A.2 Description of Activities & $\begin{array}{l}\text { Westinghouse Hanford Company } \\
\text { Diversity \& Development } \\
\text { SMS/WBS No. } 6.10 .2 .4 \\
\end{array}$ & $\begin{array}{l}\text { FY } 1995 \\
\text { Site Support Program Plan } \\
\text { Date Prepared: } 8 / 12 / 94 \\
\end{array}$ \\
\hline ACTIVITY & \multicolumn{2}{|c|}{ DESCRIPTION } \\
\hline $\begin{array}{l}\text { Diversity Strategy Integration } \\
\text { See milestone .16 } \\
(1.0 \mathrm{M} \mathrm{wi11} \mathrm{be} \mathrm{added} \\
\text { in FY 1995) }\end{array}$ & \multicolumn{2}{|c|}{$\begin{array}{l}\text { Develop interfaces with other company organizations involved in } \\
\text { diversity activities. This includes Procurement, Education } \\
\text { Outreach, Community Outreach, Employment, University/College } \\
\text { Relations, etc. Ensure that all applicable segments of } \\
\text { activities are contributing to the full implementation of this } \\
\text { strategy. }\end{array}$} \\
\hline $\begin{array}{c}\text { Support the coordination of in-house } \\
\text { and site-wide diversity celebrations } \\
\text { and outreach activities } \\
\qquad \mathrm{Ex} .1 \\
\mathrm{Nx} .1\end{array}$ & \multicolumn{2}{|c|}{$\begin{array}{l}\text {-Seven site-wide observations each year. } \\
\text { - Take Our Daughters to Work Program. } \\
\text { - Minority Youth Symposium development. } \\
\text { - Other programs as determined during implementation of the } \\
\text { Strategic Plan for Diversity. }\end{array}$} \\
\hline $\begin{array}{l}\text { Hanford Family Care Services Contract } \\
\text { Ex.1 }\end{array}$ & \multicolumn{2}{|c|}{$\begin{array}{l}\text { Administer and coordinate efforts related to the Hanford Family } \\
\text { Care Services contract with Working Solutions, Inc. Includes } \\
\text { coordination of Hanford Family Care Consortium decisions relating } \\
\text { to scheduling and logistics of onsite educational programs and } \\
\text { other provided child, adult-dependent, and elder care services. }\end{array}$} \\
\hline
\end{tabular}




\begin{tabular}{|c|c|c|}
\hline 2.A.2 Description of Activities & $\begin{array}{l}\text { Westinghouse Hanford Company } \\
\text { Diversity \& Development } \\
\text { SMS/WBS No. 6.10.2.4 }\end{array}$ & $\begin{array}{l}\text { FY } 1995 \\
\text { Site Support Program P1an } \\
\text { Date Prepared: } 8 / 12 / 94 \\
\end{array}$ \\
\hline ACTIVITY & \multicolumn{2}{|c|}{ DESCRIPTION } \\
\hline $\begin{array}{c}\text { Employee Assistance Program } \\
\mathrm{M} .2 \\
\text { Ex } 1.8 \\
\mathrm{Nx} .1 \\
\text { (This activity will be reduced } \\
\text { by } 1.0 \mathrm{Ex} \text { in } \mathrm{FY} 1995)\end{array}$ & \multicolumn{2}{|c|}{$\begin{array}{l}\text { - Consult with managers regarding workplace prob7ems with their } \\
\text { employees. } \\
\text { - In comp } 1 \text { iance with Section } 710.11 \text { Tit7e } 10 \text {, code of Federal } \\
\text { - Regulations Part } 710 \text { (10CFR } 710) \text {, DOE } N 3792.8 \text {, DOE Order } \\
5480.8 A \text {, DOE Order } 5631.6 \text {, and DOE Order } 4220.5 \text {. } \\
\text { - Provide information about services available to assist employees } \\
\text { to resolve personal situations/issues/problems. } \\
\text { - Provide short-term counseling in areas such as stress } \\
\text { management, job-related conflicts, minor child management } \\
\text { problems, decision making, bereavement, and finances. } \\
\text { - Referral to community resources for problems such as alcoholism, } \\
\text { marital therapy, and emotional disturbance. }\end{array}$} \\
\hline $\begin{array}{c}\text { EEO Complaint Resolution } \\
\text { M } .3 \\
\text { Ex } 2.0 \\
\text { Nx } .5 \\
\text { (This activity will be reduced } \\
\text { by } 5 \text { Ex in Fy } 1995 \text { however, } \\
\text { this .5 is being retained for use as } \\
\text { a rotational slot) }\end{array}$ & \multicolumn{2}{|c|}{$\begin{array}{l}\text { Represent the interests of WHC/BCSR in working to resolve formal } \\
\text { charges of discrimination filed with external agencies such as } \\
\text { the Office of Federal Contract Compliance Programs, the Equal } \\
\text { Employment Opportunity Commission, or the Washington State } \\
\text { Human Rights Commission. Includes investigation into the merits } \\
\text { of the charge, development of the position statement in response } \\
\text { to the charge and facilitation of on-site fact-finding } \\
\text { conferences if needed. } \\
\text { Receive and resolve internal complaints of discrimination } \\
\text { received from WHC/BCSR employees. These may include allegations } \\
\text { of sexual harassment, sex, age, race, religion, national origin, } \\
\text { pay equity, veteran and/or disability discrimination. }\end{array}$} \\
\hline $\begin{array}{l}\text { EEO Training } \\
\text { Ex.2 } \\
N x .1\end{array}$ & \multicolumn{2}{|c|}{$\begin{array}{l}\text { Provide mandatory EEO } 2000 \text { training to management as well as } \\
\text { other training to employees and managers on subjects related to } \\
\text { Equal Employment Opportunity/Affirmative Action such as the } \\
\text { Americans with Disabilities Act (sensitivity/etiquette, sexual } \\
\text { harassment, and Managing Diversity. }\end{array}$} \\
\hline
\end{tabular}




\begin{tabular}{|c|c|}
\hline 2.A.2 Description of Activities & $\begin{array}{l}\text { Hestinghouse Hanford Company } \\
\text { Diversity \& Development } \\
\text { SMS/WBS No. } 6.10 .2 .4 \\
\end{array}$ \\
\hline ACTIVITY & DESCRIPTION \\
\hline $\begin{array}{l}\text { Affirmative Action PTans } \\
\qquad \begin{array}{r}M \\
\text { Ex }\end{array} .4 \\
\mathrm{Nx} .2 \\
\text { See milestones } .14 \text { (BCSR) } \\
\text { and } .15 \text { (WHC) }\end{array}$ & $\begin{array}{l}\text { Prepare, implement and monitor separate Affirmative Action Plans } \\
\text { for Minorities and Females for Westinghouse Hanford Company and } \\
\text { Boieing Computer Services Richland. Required by Executive Order } \\
11246 \text {. } \\
\text { Prepare, implement and monitor separate Affirmative Action Plans } \\
\text { Veterans and People with Disabilities for. Westinghouse Hanford } \\
\text { Company and Boeing Computer Services Richland. }\end{array}$ \\
\hline $\begin{array}{l}\text { Disability Accommodations } \\
\text { Ex } .5 \\
\mathrm{Nx} .2 \\
\text { (This activity will be reduced } \\
\text { by .5 Ex in FY 1995) }\end{array}$ & $\begin{array}{l}\text { Review requests of employees, applicants, visitors and others as } \\
\text { appropriate who have disabilities to determine reasonable } \\
\text { accommodation. This includes conducting formal accommodation } \\
\text { reviews for employees or applicants on an as - requested bases. } \\
\text { The reviews consist of determining the essential functions of an } \\
\text { employee's job via a documented Job Task Analysis, determining } \\
\text { the job functions that cannot be performed, determining ways to } \\
\text { overcome barriers, and implementing the actions. May also } \\
\text { include development of direct threat analyses in certain } \\
\text { situations. } \\
\text { Milestone FAH-94-005 }\end{array}$ \\
\hline $\begin{array}{l}\text { Administer Total Quality } \\
\qquad \begin{array}{r}M \\
\text { Ex } .4 \\
\mathrm{NX} .25\end{array} \\
\text { (This activity will be reduced } \\
\text { by .15 NX in } \mathrm{FY} 1995 \text { ) }\end{array}$ & $\begin{array}{l}\text { This activity includes participation in regular meetings of the } \\
\text { Hanford Quality Integration Team and special initiatives } \\
\text { identified by DOE. While the scope is still evolving, the } \\
\text { Hanford wide assessment is estimated by DOE to involve at least } \\
600 \text { staffhours. } \\
\text { This includes Total Quality Management work, which is additional } \\
\text { scope to that performed by L\&OD in FY 1994. }\end{array}$ \\
\hline $\begin{array}{l}\text { Professional Development Courses } \\
\qquad \begin{array}{c}M \\
\text { Ex } .2\end{array}\end{array}$ & $\begin{array}{l}\text { Develop, design and deliver professional development courses to } \\
\text { support the needs of the customers. }\end{array}$ \\
\hline
\end{tabular}




\begin{tabular}{|c|c|}
\hline 2.A.2 Description of Activities & $\begin{array}{l}\text { Westinghouse Hanford Company } \\
\text { Diversity \& Development } \\
\text { SHS/WBS No. } 6.10 .2 .4\end{array}$ \\
\hline ACTIVITY & DESCRIPTION \\
\hline $\begin{array}{l}\text { Coordinate the use of on and offsite } \\
\text { resources for individual/team } \\
\text { development and improvement } \\
M .5 \\
\text { Ex } .4 \\
N x .75 \\
\text { (This activity will be reduced } \\
\text { by } .35 \mathrm{NX} \text { in FY 1995) }\end{array}$ & $\begin{array}{l}\text { Compare the company resources against the service to be provided } \\
\text { and determine the best use of taxpayer dollars. This includes } \\
\text { total quality tools and processes as well as team and } \\
\text { organizational development services. } \\
\text { This includes Total Quality Management work, which is additional } \\
\text { scope to that performed by L\&OD in FY } 1994 \text {. }\end{array}$ \\
\hline $\begin{array}{l}\text { Team and Organization Development } \\
\text { Mx } .3 \\
\text { Ex } 6.0 \\
N x .7 \\
\text { (This activity will be reduced } \\
\text { by } .5 \mathrm{Nx} \text { in } \mathrm{FY} \mathrm{1995)}\end{array}$ & $\begin{array}{l}\text { Determine and deliver services and resources that will enable an } \\
\text { organization to improve productivity and team effectiveness and } \\
\text { which will support our managers and employees to apply knowledge, } \\
\text { skills and abilities to their jobs in a safe and quality manner } \\
\text { and as an active member of the workteam. } \\
\text { This includes Total quality Management work, which is additional } \\
\text { scope to that performed by L\&OD in FY } 1994 \text {. }\end{array}$ \\
\hline $\begin{array}{l}\text { Administer Training and Development } \\
\text { Activities } \\
M \quad .25 \\
\text { Ex } .4 \\
\text { Nx } 1.0 \\
\text { See milestone. } 13 \\
\end{array}$ & $\begin{array}{l}\text { This includes WSU short-courses, and internal courses. The work } \\
\text { involves registering employees, distributing pre-work as } \\
\text { appropriate, supporting preparation of course materials, } \\
\text { verifying billing, and generating follow-on materials. }\end{array}$ \\
\hline $\begin{array}{c}\text { Education Reimbursement Program } \\
M \cdot 2 \\
\mathrm{Nx} \cdot 5 \\
\text { See milestone } .13 \\
\end{array}$ & $\begin{array}{l}\text { Administer and track activities associated with the education } \\
\text { reimbursement program. This includes approving programs, } \\
\text { verifying eligibility of employees to be reimbursed, calculating } \\
\text { actual reimbursement, and tracking associated activities. }\end{array}$ \\
\hline $\begin{array}{c}\text { Manage Resource Library } \\
\mathrm{Nx} .4\end{array}$ & $\begin{array}{l}\text { Maintain the Human Resource library which contains self-directed } \\
\text { learning materials available to all employees. }\end{array}$ \\
\hline
\end{tabular}




\begin{tabular}{|c|c|}
\hline 2.A.2 Description of Activities & $\begin{array}{l}\text { Westinghouse Hanford Company } \\
\text { Diversity \& Development } \\
\text { SMS/HBS No. } 6.10 .2 .4\end{array}$ \\
\hline ACTIVITY & DESCRIPTION \\
\hline $\begin{array}{c}\text { Special Project Support } \\
M .2 \\
\text { Ex } .2 \\
\mathrm{Nx} .4\end{array}$ & $\begin{array}{l}\text { Prepare special reports for WHC, GESCO, DOE-RL and DOE-HQ } \\
\text { customers. In addition, respond to and complete work involved } \\
\text { with special projects for the department as assigned. }\end{array}$ \\
\hline $\begin{array}{l}\text { High Potential Program } \\
\text { Ex .3 }\end{array}$ & $\begin{array}{l}\text { Direct the administration of the high potential program. This } \\
\text { includes gathering employee information from identified } \\
\text { resources. }\end{array}$ \\
\hline $\begin{array}{l}\text { Management Searches } \\
\text { Ex .2 }\end{array}$ & $\begin{array}{l}\text { Provide search assistance for qualified management candidates } \\
\text { using } \\
\text { the Employee Profile System database. }\end{array}$ \\
\hline 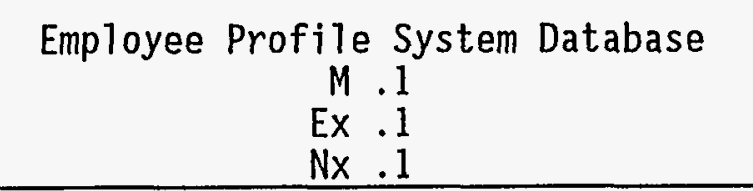 & $\begin{array}{l}\text { Support maintenance and loading of employee information as } \\
\text { required. }\end{array}$ \\
\hline $\begin{array}{c}\text { Career Development } \\
\text { Ex .2 } \\
\text { (.5 Ex will be added in FY } 1995 \text { for } \\
\text { rotational slot) }\end{array}$ & $\begin{array}{l}\text { Provide individual career development assistance and counseling } \\
\text { This will include developing career management resources for a } 11 \\
\text { WHC employees. }\end{array}$ \\
\hline $\begin{array}{l}\text { Succession Planning } \\
\text { Ex.1 } \\
\mathrm{Nx} .1\end{array}$ & $\begin{array}{l}\text { Interface with internal and external organizations in matters } \\
\text { related to promotability. }\end{array}$ \\
\hline $\begin{array}{l}\text { Jadwin Building Coverage } \\
\qquad \mathrm{Nx} 1.0\end{array}$ & $\begin{array}{l}\text { Provide full-time receptionist for } 1135 \text { Jadwin Building to } \\
\text { provide badges for visitors. This includes maintaining the } \\
\text { building log, assigning building badges to non-Hanford visitors } \\
\text { on business with building occupants. }\end{array}$ \\
\hline
\end{tabular}




\begin{tabular}{|c|c|}
\hline 2.A.2 Description of Activities & $\begin{array}{l}\text { Hestinghouse Hanford Company } \\
\text { Diversity \& Development } \\
\text { SHS/HBS No. } 6.10 .2 .4\end{array}$ \\
\hline ACTIVITY & DESCRIPTION \\
\hline 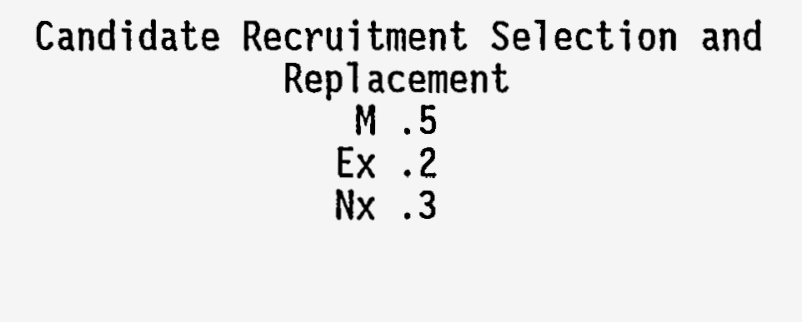 & $\begin{array}{l}\text { This is the basic function of this organization. Candidate } \\
\text { recruitment includes a regional search, supplemented by national } \\
\text { recruiting, to address diversity issues and gain highly qualified } \\
\text { candidates. Selection involves interview trips, site visits as } \\
\text { well as the associated administrative support. Placement is an } \\
\text { ongoing communication requirement to provide multiple candidates } \\
\text { the maximum of opportunity for true developmental assignments. }\end{array}$ \\
\hline $\begin{array}{l}\text { Design and implement a development } \\
\text { strategy that is participant driven } \\
\text { and program supported } \\
\text { Ex } .2 \\
\mathrm{Nx} .2\end{array}$ & $\begin{array}{l}\text { Each participant will have an initial development strategy that } \\
\text { is developed with the assistance of the Graduate Rotation Program } \\
\text { office. It will incorporate near-term, mid-term and long-term } \\
\text { goals and objectives. }\end{array}$ \\
\hline $\begin{array}{l}\text { Manage customer issues and requests } \\
\text { to effect results oriented resolution } \\
\text { and total quality service } \\
\text { M.3 } .1\end{array}$ & $\begin{array}{l}\text { These items regularly require immediate response, creating an } \\
\text { impact on daily operations. As a support function the program } \\
\text { office must be staffed to address these items in a timely, } \\
\text { quality, professional manner. Individual issues vary so greatly } \\
\text { that a staff with multiple human resources related experience is } \\
\text { required for superior performance of these duties. }\end{array}$ \\
\hline $\begin{array}{l}\text { Develop job rotation process for } \\
\text { current employees } \\
\text { See milestone } .12\end{array}$ & $\begin{array}{l}\text { Define purpose and scope, identify funding source, set staffing } \\
\text { requirements and establish participation guidelines. Develop a } \\
\text { marketing strategy and implementation plan, implement the } \\
\text { marketing strategy and gain required approval at appropriate } \\
\text { level(s). }\end{array}$ \\
\hline
\end{tabular}


DIVERSITY \& DEVL_JPMENT LEADERSHIP

FORM 2.C.3 FTEs

\begin{tabular}{|c|c|c|c|c|c|c|c|c|}
\hline Ful1-Time Equi & $f$ by Jo & escripti & & NOTE : JO] & b Family & Only Af & er 1996 & \\
\hline Joв F̈̈̆̈ILYY & & & & $\therefore$ & & $\because \because$ & $\because \vdots$ & \\
\hline Job category & 1994 & 1995 & 1996 & 1997 & 1998 & 1999 & 2000 & 2001 \\
\hline MANAGERS & 4.0 & 5.0 & $4.0 \quad \because$ & $4: 0$ & 4.0 & $\therefore 4.0^{\circ}$ & $\therefore 4.0$ & 4.0 \\
\hline First line & 2.0 & 3.0 & 3.0 & & & & & \\
\hline General/executive & 1.0 & 1.0 & 1.0 & & & & & \\
\hline Project/Program & 1.0 & 1.0 & & & & & & \\
\hline other & & & & & & & & \\
\hline ENGINEERS & & & & & & & & \\
\hline Chemical & & & & & & & & \\
\hline civil & & & & & & & & \\
\hline Computer & & & & & & & & \\
\hline Electrical & & & & & & & & \\
\hline Environmental & & & & & & & & \\
\hline industrial & & & & & & & & \\
\hline Mechanical & & & & & & & . & \\
\hline Nuclear & & & & & & & & \\
\hline Petroleum/Mining & & & & & & & & \\
\hline Plant & & & & & & & & \\
\hline Quality Control & & & & & & & & \\
\hline Safety & & & & & & & & \\
\hline other & & & & & & & & \\
\hline SCIENTISTS & & & & & & & & \\
\hline
\end{tabular}




\begin{tabular}{|c|c|c|c|c|c|c|c|c|}
\hline \multicolumn{4}{|c|}{ Full-Time Equivalent Staff by Job Description. } & \multicolumn{5}{|c|}{ NOTE: Job Family Only After 1996} \\
\hline JOB FAML LY $\quad \because \quad \vdots$ & & & 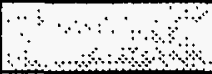 & s.m & $\sqrt{2+16}$ & $\because \because \cdots$ & आ। & is \\
\hline Job category & 1994 & 1995 & 1996 & 1997 & 1998 & 1999 & 2000 & 2001 \\
\hline \multicolumn{9}{|l|}{ Chemists } \\
\hline \multicolumn{9}{|l|}{ Environmental } \\
\hline \multicolumn{9}{|l|}{ Geologists } \\
\hline \multicolumn{9}{|l|}{ Life } \\
\hline \multicolumn{9}{|l|}{ Material } \\
\hline \multicolumn{9}{|l|}{ Mathematicians } \\
\hline \multicolumn{9}{|l|}{ Physicists } \\
\hline \multicolumn{9}{|l|}{ Social } \\
\hline \multicolumn{9}{|l|}{ other } \\
\hline AB̈MIN/OTHER PROFESSIONALS & 16.0 & 15.0 & 15.0 & 15.0 & 10.0 & $10: 0$ & 10.0 & 10.0 \\
\hline \multicolumn{9}{|l|}{ Accountant/auditor } \\
\hline \multicolumn{9}{|l|}{ Architect } \\
\hline \multicolumn{9}{|l|}{ Buyers/procurement } \\
\hline \multicolumn{9}{|l|}{ Comnunications } \\
\hline \multicolumn{9}{|l|}{ Compl iance inspectors } \\
\hline \multicolumn{9}{|l|}{ Computer System Anal } \\
\hline \multicolumn{9}{|l|}{ Cost Est/planner/sch } \\
\hline \multicolumn{9}{|l|}{ Heal th Physics } \\
\hline \multicolumn{9}{|l|}{ Industrial Hygiene } \\
\hline Lawyers & & & & & & & & \\
\hline
\end{tabular}




\begin{tabular}{|c|c|c|c|c|c|c|c|c|}
\hline Ful1-Time Equivalen & $f$ by Jo & escripti & & NOTE : JO & b Family & Only Afte & er 1996 & \\
\hline JOB FAMILYY & & & $\begin{array}{c:c}* & : \cdots \\
\ldots & \cdots\end{array}$ & 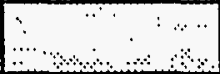 & 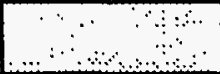 & a & $\begin{array}{lll}\cdots & \cdots\end{array}$ & \\
\hline Job category & 1994 & 1995 & 1996 & 1997 & 1998 & 1999 & 2000 & 2001 \\
\hline Personnel/Labor Rela & 16.0 & 15.0 & 13.0 & & & & & \\
\hline Physicians & & & & & & & & \\
\hline Physician Assis/Nurs & & & & & & & & \\
\hline Safeguard \& Security & & & & & & & & \\
\hline Tech Writers \& Edit & & & & & & & & \\
\hline Trainers & & & & & & & & \\
\hline Other & & & & & & & & \\
\hline JOB FAMILY & & & & & & $\therefore$ & & \\
\hline Job category & & & & & & & & \\
\hline GEN ADN/SECRETARY/CLLERK & 7.5 & 7.1 & 7.1 & 7.1 & $7.1 \vdots$ & 7.1 & 71 & 7.1 \\
\hline Admin Assistants & & & & & & & & \\
\hline Office Clerks (Gen) & & & & & & & & \\
\hline office Clerks (Special) & 3.0 & 3.0 & 3.0 & & & & & \\
\hline Secretaries & 3.0 & 2.0 & 2.0 & & & & & \\
\hline Typist/Word Process & & & & & & & & \\
\hline Other - Temporary & 2.1 & 2.1 & 2.1 & & & & & \\
\hline TECHNICIANS & & & & & & & & \\
\hline Computer Oper/Coder & & & & & & & & \\
\hline Drafters & & & & & & & & \\
\hline Engrs/Tech & & & & & & & & \\
\hline
\end{tabular}




\begin{tabular}{|c|c|c|c|c|c|c|c|c|}
\hline Full-Time Equivale & $f$ by & escr & & NOTE: Jo? & b Family & Only Aft & er 1996 & \\
\hline JOB FAMHLY $\quad$ & & & $\because$ & נ. & $\because$ & @ & औ & \\
\hline Job category & 1994 & 1995 & 1996 & 1997 & 1998 & 1999 & 2000 & 2001 \\
\hline Envir. Sci Technicians & & & & & & & & \\
\hline Heal th Phys. Technic. & & & & & & & & \\
\hline Indus. Saf/Heal th Tech & & & & & & & & \\
\hline Instru/Contral Tech & & & & & & & & \\
\hline Lab. Technicians & & & & & & & & \\
\hline Media Technicians & & & & & & & & \\
\hline Survey/Map Tech & & & & & & & & \\
\hline other & & & & & & & & \\
\hline CRAFTS & & & & & & . & & \\
\hline Carpenters & & & & & & & & \\
\hline Electricians & & & & & & & & \\
\hline HVAC & & & & & & & & \\
\hline Machinists & & & & & & & & \\
\hline Masons & & & & & & & & \\
\hline Millwrights & & & & & & & & \\
\hline Painters & & & & & & & & \\
\hline Plumbers/Pipefitters & & & & & & & & \\
\hline Struct/Metal Workers & & & & & & & & \\
\hline Vehic./Mob Equip Mech & & & & & & & & \\
\hline Helders & & & & & & & & \\
\hline
\end{tabular}




\begin{tabular}{|c|c|c|c|c|c|c|c|c|}
\hline \multicolumn{4}{|c|}{ Ful1-Time Equivalent Staff by Job Description } & \multicolumn{5}{|c|}{ NOTE: Job Family Only After 1996} \\
\hline SOB FAMILY : $:$ & & & & a & $\because$ & & बi & $\therefore$ \\
\hline Job category & 1994 & 1995 & 1996 & 1997 & 1998 & 1999 & 2000 & 2001 \\
\hline \multicolumn{9}{|l|}{ other } \\
\hline \multirow{2}{*}{\multicolumn{9}{|c|}{$\frac{\text { Chemical system }}{\text { OPERATORS }}$}} \\
\hline & & & & & & & & \\
\hline \multicolumn{9}{|l|}{ Drillers } \\
\hline \multicolumn{9}{|l|}{ Lt. Vehicle Drivers } \\
\hline \multicolumn{9}{|c|}{ Material Moving Equip } \\
\hline \multicolumn{9}{|l|}{ Nuclear Plant } \\
\hline \multicolumn{9}{|c|}{ Utilities Haste Proces } \\
\hline \multicolumn{9}{|l|}{ Other } \\
\hline \multicolumn{9}{|l|}{ LABOR \& GEN HORKERS } \\
\hline \multicolumn{9}{|l|}{ Firefighters } \\
\hline \multicolumn{9}{|l|}{ Food Service } \\
\hline \multicolumn{9}{|l|}{ Hand/Help Lab Gen } \\
\hline \multicolumn{9}{|l|}{ Hand/Help Lab Spec } \\
\hline \multicolumn{9}{|l|}{ Jani tors/Cleaners } \\
\hline \multicolumn{9}{|l|}{ Laundry Horkers } \\
\hline \multicolumn{9}{|l|}{ Security Guards } \\
\hline \multicolumn{9}{|l|}{ other } \\
\hline TOTAL & $\star 23.1$ & 27.1 & 26.1 & 26.1 & 21.1 & 21.1 & 21.1 & 21.1 \\
\hline
\end{tabular}

* Approved 1994 Fiscal Year Work Plan 
吾 


\begin{tabular}{|l|c|c|}
\hline 1.A Vision/Mission & $\begin{array}{c}\text { Westinghouse Hanford Company } \\
\text { L\&OD } \\
\text { SMSMBS No. 6.10.2.4 }\end{array}$ & $\begin{array}{c}\text { FY 1995 } \\
\text { Site Support Program Plan } \\
\text { Date Prepared: 8/31/94 }\end{array}$ \\
\hline
\end{tabular}

The mission of Leadership and Organization Development is to identify and provide the services and resources to projects which will improve productivity, quality; team effectiveness; and which will support the management and employees in applying the knowledge, skills and abilities to perform their jobs in a safe and quality manner. 


\begin{tabular}{|l|c|c|}
\hline $\begin{array}{c}\text { 1.B.1 Internal Assessment } \\
\text { Summary }\end{array}$ & $\begin{array}{c}\text { Westinghouse Hanford Company } \\
\text { L\& OD }\end{array}$ & $\begin{array}{c}\text { FY 1995 } \\
\text { Site Support Program Plan } \\
\text { Date Prepared: } 8 / 31 / 94\end{array}$ \\
\hline
\end{tabular}

\section{PRIMARY CUSTOMERS}

Westinghouse Hanford Company Programs

Westinghouse Hanford Company President, Vice Presidents and Directors

Department of Energy- Richland Operations Office

Westinghouse Electric Corporation - GESCO

Taxpayers

\section{PRODUCTS/SERVICES PROVIDED}

- Identify appropriate resources and services for employees, organizations and projects at all levels that are consistent with Company objectives

- Manage internal and external total quality resources and activities to meet the customers' needs.

- Address specific organizational needs which will lead to total performance leadership

- Provide organization and team development services

- Provide evaluation and follow up services

- Assess and design inter and intra organization development strategies, including goal setting and group/team development

- Integrate quality improvement processes and philosophy into services provided to the projects.

- Deliver quality tools and resources based on mutually identified customer needs.

\section{MAJOR ACTIVITIES PERFORMED TO DELIVERY PRODUCTS AND SERVICES}

- Prepare and implement plans for organizational needs assessments

- Interface regularly with DOE-RL Total Quality office

- Participating membership on the Hanford Quality Integration Team

- Manage contracts with vendor-provided total quality services

- Serve as member of DOE-sponsored Training Resource And Data Exchange (TRADE) Special Interest Group

- Complete action items which result from TRADE SIG membership 


\begin{tabular}{|l|c|c|}
\hline $\begin{array}{c}\text { 1.B.1 Internal Assessment } \\
\text { Summary }\end{array}$ & $\begin{array}{c}\text { Westinghouse Hanford Company } \\
\text { Program Title } \\
\text { SMS/WBS No. }\end{array}$ & $\begin{array}{c}\text { FY } 1995 \\
\text { Site Support Program Plan } \\
\text { Date Prepared: }\end{array}$ \\
\hline
\end{tabular}

- Design and development of "training" resulting from external audit findings

- Actively involve employees to resolve workplace issues and make workplace improvements

- Actively perform the Quality Coordinator roles and responsibilities

- Certify Leadership \& Organization Development consultants in quality improvement and change management tools

- Provide oral quarterly reports on organization development projects, challenges, and successes

- Implementation of actions resulting from participation on DOE directed Hanford task teams and committees

- Generate special surveys and reports as directed by WHC management, DOE-RL, and Westinghouse Electric

\section{EVALUATION OF MAJOR ACTIVITIES (COST, VALUE-ADDED, ETC.)}

- Organization development improves the productivity and effectiveness of organizations, teams, and individuals. This is increasing in importance as we downsize and reorganize the site.

- Professional development resources improve or develop knowledge, skills, and abilities of employees so that they can perform quality work safely and as a valued member of the team.

- Supporting Hanford-wide activities provides integration and consistency of thought, but removes significant resources from program-directed work.

\section{FACTORS WHICH INFLUENCE RESQURCE CONSUMPTION (CHANGES TO COST AND VOLUME}

- Requests from RL are more Hanford-wide in nature and are continually evolving.

\section{EACTORS THAT INFLUENCE CHANGES IN TYPES OR NATURE OF PRODUCTS and SERVICES}




\begin{tabular}{|c|c|c|}
\hline $\begin{array}{c}\text { 1.B.2 External Assessment } \\
\text { Summary }\end{array}$ & $\begin{array}{c}\text { Westinghouse Hanford Company } \\
\text { L \& OD } \\
\text { SMSMBS No. 6.10.2.4 }\end{array}$ & $\begin{array}{c}\text { FY 1995 } \\
\text { Site Support Program Plan } \\
\text { Date Prepared: 8/31/94 }\end{array}$ \\
\hline
\end{tabular}

\section{SUMMARY OF CUSTOMER REQUIREMENTS (NEEDS)}

The customers needs are more Hanford-wide in nature and include the needs for alignment to strategic goals and plans which cascade through the organization.

\section{QTHER EXTERNAL CHALLENGES}

Our DOE customer needs are more Hanford-wide in nature and are continually evolving. They include, but are limited to, required adherence to DOE quality goals, workforce restructuring, and aligning to processes not yet established. 


\begin{tabular}{|l|c|c|}
\hline 1.C Goals and Objectives & $\begin{array}{c}\text { Westinghouse Hanford Company } \\
\text { L \& OD }\end{array}$ & $\begin{array}{c}\text { FY 1995 } \\
\text { Site Support Program Plan } \\
\text { Date Prepared: } 8 / 31 / 94\end{array}$ \\
\hline
\end{tabular}

1. Enable organization to develop effective customer and team interface strategies.

2. Design and consult on organizational change projects to enhance the performance of the organization. 


\begin{tabular}{|l|c|c|}
\hline 1.D Strategies & $\begin{array}{c}\text { Westinghouse Hanford Company } \\
\text { L \& OD }\end{array}$ & $\begin{array}{c}\text { FY 1995 } \\
\text { Site Support Program Plan } \\
\text { Date Prepared: 8/31/94 }\end{array}$ \\
\hline
\end{tabular}

\section{CUSTOMER SUPPORT STRATEGIES}

- Develop effective working relationship with DOE-RL Total Quality Department.

- Align and work with each project manager to develop strategies for achieving his mission and the Company's mission.

PRODUCTION STRATEGIES

- Match service to customer needs.

QRGANIZATION and MANAGEMENT STRATEGIES 


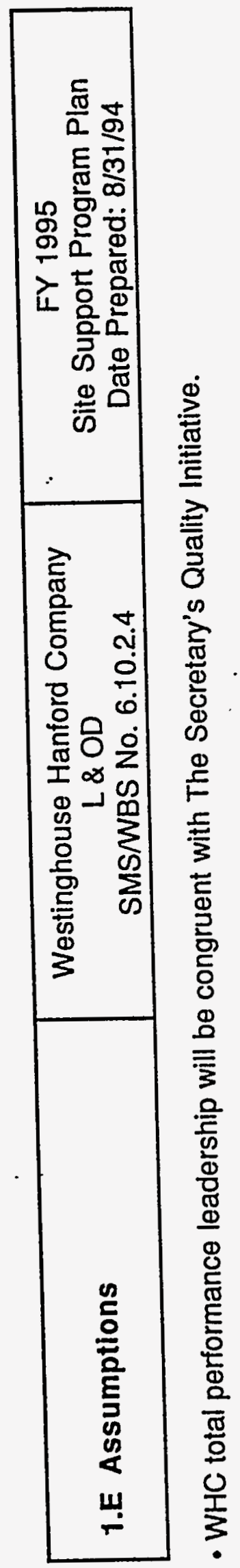




\begin{tabular}{|l|c|c|}
\hline 1.F Issues and Constraints & $\begin{array}{c}\text { Westinghouse Hanford Company } \\
\text { L\& OD }\end{array}$ & $\begin{array}{c}\text { FY 1995 } \\
\text { Site Support Program Plan } \\
\text { Date Prepared: } 8 / 31 / 94\end{array}$ \\
\hline
\end{tabular}

- Actions from Hanford Quality Integration Team are not yet known. 


\begin{tabular}{|l|c|c|}
\hline 1.G Performance Measures & $\begin{array}{c}\text { Westinghouse Hanford Company } \\
\text { L \& OD }\end{array}$ & $\begin{array}{c}\text { FY 1995 } \\
\text { Site Support Program Plan } \\
\text { Date Prepared: } 8 / 31 / 94\end{array}$ \\
\hline
\end{tabular}

Our performance will be measured by an assessment process, applied client-by-client, yet to be developed by L\&OD. 


\begin{tabular}{|c|c|c|}
\hline 2.A.2 Description of Activities & $\begin{array}{l}\text { Westing ise Hanford } \\
\text { Company } \\
\text { Diversity \& Development } \\
\text { SMS/WBS No. } 6.10 .2 .4 \\
\end{array}$ & $\begin{array}{c}\text { FY } 1995 \\
\text { Site Support Program Plan } \\
\text { Date Prepared: } 8 / 12 / 94\end{array}$ \\
\hline ACTIVITY & \multicolumn{2}{|c|}{ DESCRIPTION } \\
\hline $\begin{array}{l}\text { Administer Total Quality } \\
\qquad \begin{array}{l}\text { M.1 } \\
\text { Ex.4 } \\
\text { Nx.25 }\end{array} \\
\text { (This activity will be reduced } \\
\text { by .15 Nx in FY 1995) }\end{array}$ & \multicolumn{2}{|c|}{$\begin{array}{c}\text { This activity includes participation in the regular meetings of the Hanford } \\
\text { Quality Integration Team and special initiatives identified by DOE. While } \\
\text { the scope is still evolving, the Hanford wide assessment is estimated by } \\
\text { DOE to involve at least } 600 \text { staffhours. } \\
\text { This includes Total Quality Management work, which is additional scope } \\
\text { to that performed by L\&OD in FY } 1994 \text {. }\end{array}$} \\
\hline $\begin{array}{l}\text { Coordinate the use of on and offsite } \\
\text { resources for individual/team } \\
\text { development and improvement } \\
\mathrm{M} .5 \\
\mathrm{Ex} .4 \\
\mathrm{Nx} .75 \\
\text { (This activity will be reduced } \\
\text { by } .35 \mathrm{Nx} \text { in FY 1995) }\end{array}$ & \multicolumn{2}{|c|}{$\begin{array}{l}\text { Compare the company resources against the service to be provided and } \\
\text { determe the best use of taxpayer dollars. This includes total quality tools } \\
\text { and processes as well as team and organizational development services } \\
\text { This includes Total Quality Management work, which is additional scope } \\
\text { to that performed by L\&OD in FY } 1994 \text {. }\end{array}$} \\
\hline $\begin{array}{l}\text { Team and Organization Development } \\
M .3 \\
\text { Ex } 6.0 \\
\mathrm{Nx} .7 \\
\text { (This activity will be reduced } \\
\text { by } .5 \mathrm{NX} \text { in } \mathrm{FY} \text { 1995) }\end{array}$ & \multicolumn{2}{|c|}{$\begin{array}{c}\text { Determine and deliver services and resources that will enable an } \\
\text { organization to improve productivity and team effectiveness and which } \\
\text { will support our managers and employees to apply knowledge, skills and } \\
\text { abilities to their jobs in a safe and quality manner and as an active } \\
\text { member of the workteam. } \\
\text { This includes Total Quality Management work, which is additional scope } \\
\text { to that performed by L\&OD in FY } 1994 \text {. }\end{array}$} \\
\hline $\begin{array}{l}\text { Professional Development Courses } \\
\qquad \text { M.1 } \\
\text { Ex.2 }\end{array}$ & \multicolumn{2}{|c|}{$\begin{array}{l}\text { Develop, design and deliver professional development courses to } \\
\text { support the needs of the customers. }\end{array}$} \\
\hline
\end{tabular}




\section{Leadership \& Organizátion Development}

\section{Quality Deliverables}

Date prepared: $8 / 31 / 94$

\section{Deliverable}

- Lead the Agenda Planning committee for Quality Coordinator Meeting

\section{Date}

Tranismit a copy of the agenda to DOE-RL

$11 / 94$

- Partner with other Quality Coordinators to develop and present a proposal to form a Quality Coordinator Executive Committee.

Transmit a copy to DOE-RL

$11 / 94$

- Develop an assessment process for evaluating L\&OD's effectiveness, of quality consulting services, by the customers.

Transmit hard copy of process to DOE-RL

by $2 / 95$

- Report results of assessment process to DOE-RL on a quarterly basis

Quarterly

- Report total quality achievements/outcomes to DOE-RL Total Quality Office.

Quarterly 


\section{MILESTONE DESCRIPTION SHEET}

\begin{tabular}{|c|c|c|c|}
\hline $\begin{array}{c}\therefore \\
\text { Graduate Rotational }\end{array}$ & grams & & $\begin{array}{l}\text { Date: } \\
08 / 11 / 94 \\
\end{array}$ \\
\hline \multicolumn{3}{|c|}{$\begin{array}{l}\text { Assigned To: } \\
\text { Greg Mitchel1 }\end{array}$} & CIN: \\
\hline \multicolumn{3}{|c|}{$\begin{array}{l}\text { Program WBS Designator: } \\
6.10 .2 .4 .1\end{array}$} & $\begin{array}{l}\text { Due Date: } \\
9 / 30 / 95\end{array}$ \\
\hline \multicolumn{3}{|c|}{ Control Number: FAH-95-012 } & Rev.: \\
\hline $\begin{array}{l}\text { MILESTONE TYPE: } \\
\square \text { DOE-HO } \\
\square \text { DOE-RL } \\
\square \text { CNTR }\end{array}$ & $\begin{array}{l}\text { DIVISION: } \\
\square \text { State } \\
\square \text { Federal } \\
\square \text { DOE } \\
\square \text { RCRA } \\
\square \text { TPA Number }\end{array}$ & $\begin{array}{l}\text { DELIVERABLE: } \\
\square \text { Report } \\
\square \text { Letter } \\
\square \text { Drawings } \\
\square \text { Other (specify) }\end{array}$ & $\begin{array}{l}\text { ADDRESS TO: } \\
\square \text { DOE-HQ } \\
\square \text { DOE-RL } \\
\square \text { Other (specify) }\end{array}$ \\
\hline
\end{tabular}

Milestone description:

Development and implementation of a rotation process for current employees

to accelerate the broadening of skills for future Hanford Site activities.

$\begin{array}{ll}M & .2 \\ \text { Ex } & .5 \\ N x & .5\end{array}$

Description of what constitutes completion of this milestone:

A written report describing the rotation process.

\begin{tabular}{|c|c|c|c|}
\hline $\begin{array}{l}\text { 'st Account Manager } \\
\text { A. A. Powers }\end{array}$ & Date & $\begin{array}{l}\text { Program/Project Manager } \\
\text { L. L. Myers }\end{array}$ & Date \\
\hline Program Element Manager & Date & $\begin{array}{l}\text { DOE Monitor } \\
\text { S. A. Hostick }\end{array}$ & Date \\
\hline
\end{tabular}




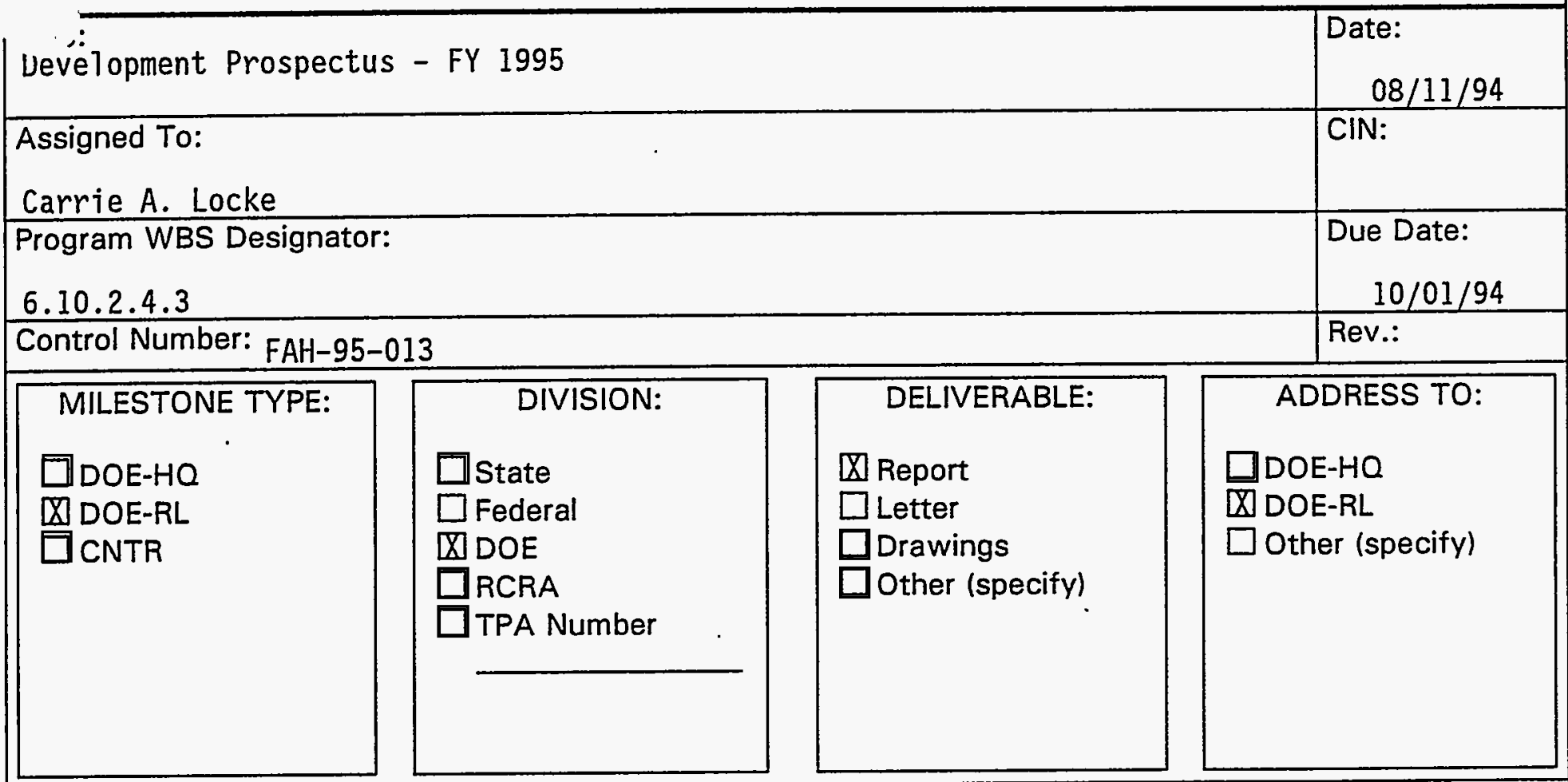

Milestone description:

This prospectus describes the scope of professional development in

Westinghouse Hanford Company, Boeing Computer Services, Richland and ICF

Kaiser Hanford. The prospectus covers three broad areas: on-site management and employee development, off-site courses, and the educational assistance program.

$\begin{array}{ll}M & .05 \\ \text { Ex } & .1 \\ \text { NX } & .1\end{array}$

Description of what constitutes completion of this milestone:

Delivery of the completed report to RL on or before October 1, 1994.

'st Account Manager

1. A. Powers

Program Element Manager
Date

Date
Program/Project Manager

L. L. Myers

DOE Monitor

S. A. Hostick
Date

Date 


\section{Westinghouse Hanford Company \\ MILESTONE DESCRIPTION SHEET}

\begin{tabular}{|c|c|c|c|}
\hline \multicolumn{3}{|c|}{$\begin{array}{l}\text { BCSR Affirmative Action Plan for Minorities and Women }\end{array}$} & \begin{tabular}{|l|} 
Date: \\
$08 / 11 / 94$ \\
\end{tabular} \\
\hline \multicolumn{3}{|c|}{$\begin{array}{l}\text { Assigned To: } \\
\text { F. A. Powers } \\
\end{array}$} & CIN: \\
\hline \multicolumn{3}{|c|}{ Program WBS Designator: } & \begin{tabular}{|r|} 
Due Date: \\
$11 / 01 / 94$ \\
\end{tabular} \\
\hline \multicolumn{3}{|c|}{ Control Number: $F A H-95-014$} & Rev.: \\
\hline $\begin{array}{l}\text { MILESTONE TYPE: } \\
\square \text { DOE-HO } \\
\text { Х DOE-RL } \\
\square \text { CNTR }\end{array}$ & $\begin{array}{l}\quad \text { DIVISION: } \\
\square \text { State } \\
\square \text { Federal } \\
\text { ХDOE } \\
\square \text { RCRA } \\
\square \text { TPA Number }\end{array}$ & $\begin{array}{l}\text { DELIVERABLE: } \\
\bigotimes \text { Report } \\
\square \text { Letter } \\
\square \text { Drawings } \\
\square \text { Other (specify) }\end{array}$ & $\begin{array}{l}\text { ADDRESS TO: } \\
\square \text { DOE-HQ } \\
\text { XDOE-RL } \\
\square \text { Other (specify) }\end{array}$ \\
\hline
\end{tabular}

Milestone description:

Prepare the FY 1995 Boeing Computer Services; Richland Affirmative Action

$\mathrm{PT}$ an for minorities and women based on the requirements as stated in 41 CFR

60-2. Purpose is to document good faith efforts of the Company relative to

the placement of minorities and women in all job categories, and to.

establish FY 1995 goals.

Ex $\quad .1$

Each federal contractor is required by Executive Order 11246 to have a written affirmative action $\mathrm{plan}$ in $\mathrm{place}$.

Description of what constitutes completion of this milestone:

Delivery of the completed Affirmative Action Plan to RL on or before

November 1, 1994.

st Account Manager

Date

Program/Project Manager

Date

.. A. Powers

L. L. Myers

Program Element Manager

Date

DOE Monitor

Date

S. A. Hostick 


\section{Westinghouse Hanford Company \\ MILESTONE DESCRIPTION SHEET}

3: wrC Affirmative Action PIan for Minorities and Women

Assigned To:

F. A. Powers

Program WBS Designator:

Due Date:

6.10 .2 .4

Control Number: FAH-95-015

\begin{tabular}{|c|c|c|}
\hline $\begin{array}{l}\text { MILESTONE TYPE: } \\
\square \text { DOE-HO } \\
{[\mathrm{X} \text { DOE-RL }} \\
\square \text { CNTR }\end{array}$ & $\begin{array}{l}\text { DIVISION: } \\
\square \text { State } \\
\square \text { Federal } \\
\square \text { DOE } \\
\square \text { RCRA } \\
\square \text { TPA Number }\end{array}$ & $\begin{array}{l}\text { DELIVERABLE: } \\
\square \text { Report } \\
\square \text { Letter } \\
\square \text { Drawings } \\
\square \text { Other (specify) }\end{array}$ \\
\hline
\end{tabular}

$11 / 01 / 94$

Rev.:

$08 / 11 / 94$

CIN:

Milestone description:

Prepare the FY 1995 Westinghouse Hanford Company Affirmative Action Plan for minorities and women based on the requirements as stated in 41 CFR 60-2.

Purpose is to document good faith efforts of the Company relative to the placement of minorities and women in all job categories, and to establish FY 1995 goals.

$\begin{array}{ll}M & .1 \\ \text { Ex } & .2 \\ \mathrm{Nx} & .2\end{array}$

Description of what constitutes completion of this milestone:

Delivery of the completed Affirmative Action P7an to DOE-RL on or before November 1, 1994.

\begin{tabular}{|c|c|c|c|}
\hline $\begin{array}{l}\text { anst Account Manager } \\
\therefore \text { A. Powers }\end{array}$ & Date & $\begin{array}{l}\text { Program/Project Manager } \\
\text { L. L. Myers }\end{array}$ & Date \\
\hline Program Element Manager & Date & $\begin{array}{l}\text { DOE Monitor } \\
\text { S. A. Hostick }\end{array}$ & Date \\
\hline
\end{tabular}




\section{Westinghouse Hanford Company \\ MILESTONE DESCRIPTION SHEET}

\begin{tabular}{l|l|l}
\hline & Date:
\end{tabular}

Develop An Integrated Strategic P1an For Diversity

Assigned To:

$08 / 11 / 94$

CIN:

F. A. Powers

Program WBS Designator:

Due Date:

6.10 .2 .4

$9 / 30 / 95$

Control Number: FAH-94-016

\begin{tabular}{|c|c|c|c|}
\hline MILESTONE TYPE: & DIVISION: & DELIVERABLE: & ADDRESS TO: \\
\hline $\begin{array}{l}\square \text { DOE-HO } \\
\text { 囚 DOE-RL } \\
\square \text { CNTR }\end{array}$ & $\begin{array}{l}\square \text { State } \\
\square \text { Federal } \\
\text { \DOE } \\
\square \text { RCRA } \\
\square \text { TPA Number }\end{array}$ & $\begin{array}{l}\text { X) Report } \\
\square \text { Letter } \\
\square \text { Drawings } \\
\square \text { Other (specify) }\end{array}$ & $\begin{array}{l}\square D O E-H Q \\
\square D O E-R L \\
\square \text { Other (specify) }\end{array}$ \\
\hline
\end{tabular}

Milestone description:

Develop an implementation $\mathrm{plan}$ for the Integrated Diversity Strategy. The purpose of this is to provide a targeted implementation of the concept of diversity into all aspects of the company's business in order that WHC might capitalize on different perspectives in the pursuit of mission accomplishment. The areas of focus include Educational Outreach, Workforce Diversity, Community Outreach and Sma71 and Disadvantaged Business involvement.

$\begin{array}{ll}M & .3 \\ \text { Ex } & .6 \\ \text { NX } & .2\end{array}$

Description of what constitutes completion of this milestone:

Develop and deliver to RL the implementation plans for each of the four

focus areas of the Diversity Stratigic Plan as follows:

The following due dates are actualiy interim milestones for internal

monitoring toward completion of the RL milestone.

1) Partnering with our workforce December 31. 1994

2) Education Outreach

March 31, 1995

3) Community Outreach

June 30,1995

4) Sma 17 and Disadvantaged Business

September 30, 1995

Commitment

\begin{tabular}{|c|c|c|c|}
\hline $\begin{array}{l}\text { sst Account Manager } \\
\text { with A. Powers }\end{array}$ & Date & $\begin{array}{l}\text { Program/Project Manager } \\
\text { L. L. Myers }\end{array}$ & Date \\
\hline Program Element Manager & Date & $\begin{array}{l}\text { DOE Monitor } \\
\text { S. A. Hostick }\end{array}$ & Date \\
\hline
\end{tabular}




\begin{tabular}{|l|c|c|}
\hline 1.A Vision/Mission & $\begin{array}{c}\text { Westinghouse Hanford Company } \\
\text { HR Staff Relations } \\
\text { SMS/WBS No. 6.10.2.8 }\end{array}$ & $\begin{array}{c}\text { FY 1995 } \\
\text { Site Support Program Plan } \\
\text { Date Prepared: } 8 / 12 / 94\end{array}$ \\
\hline
\end{tabular}

\section{VISION/MISSION}

Actively support the attainment of WHC business objectives by ensuring that the management of Human Resources (HR) Staff Relations is integrated into the strategic and operational aspects of WHC. More specifically, provide the lead role for Hanford Site contractors in strategic planning, coordinating and negotiating of the Collective Bargaining Agreements with the Hanford Atomic Metal Trades Council (HAMTC) and the Hanford Guards Union (HGU). Provide guidance in labor contract interpretation and review and grievance answers. Assist in resolving workplace conflicts and help develop performance improvement plans. Support all WHC organizations, providing a one-stop focus by interfacing with other HR functions. Provide guidance on salary continuation/absence pay decisions, and review all potential disciplinary actions with management. 


\section{SITUATIONAL ANALYSIS}

HR Staff Relations is organized to align resources to directly support the program/project teams. Through this process, the matrixed organization will provide a more focused delivery of employee and labor relations services to our customers. The aligned HR managers will coordinate and interface with HR Central Services and Diversity \& Development Leadership representatives assigned to support programs/projects.

\section{PRIMARY CUSTOMERS}

The Department of Energy, Richland Operations Office (RL) HR Division

WHC/BCSR

Westinghouse Electric Corporation (WEC)

\section{MAJOR ACTIVITIES PERFORMED TO DELIVER PRODUCTS AND SERVICES}

- Resolve day-to-day union problems to avoid formal grievances and their associated costs.

- $\quad$ Provide guidance to line management in responding to first and second step grievance answers.

- Represent the Company's interest at Third Step Grievance meetings with HAMTC and HGU.

- Provide input and assist the labor counsel in the preparation of grievance arbitration hearings.

- Work in conjunction with the labor counsel providing support in preparation for responding to National Labor Relations Board charges and litigations.

- Provide oversight and guidance to management, ensuring maximum utilization of the Craft Alignment Program and Temporary Employee provisions of the Collective Bargaining Agreement.

- Provide the lead in strategic planning and negotiations for training and certification programs covering a broad range of activities with various union affiliates. 


\section{B.1 Internal Assessment Summary}

Westinghouse Hanford Company

HR Staff Relations

SMS/WBS No. 6.10.2.8

FY 1995

Site Support Program Plan

Date Prepared: $8 / 12 / 94$

\section{MAJOR ACTIVITIES PERFORMED TO DELIVER PRODUCTS AND SERVICES (continued)}

- Provide the lead role for Hanford site contractors in strategic planning, coordinating and negotiating Collective Bargaining Agreements with HAMTC and HGU.

- Provide substantial advice and counsel to ICF Kaiser (ICF-KH) and Bechtel Hanford, Inc. (BHI) regarding labor/employee relations issues.

- Provide proactive support, counsel and guidance to managers and non-bargaining employees to ensure maintenance of Westinghouse represented status.

- Initiate and monitor policies, procedures and management practices to ensure compliance with federal and state laws.

- Provide HR counsel in the management of highly visible issues that carry potential major cost impacts such as employee concerns, disciplinary. actions, plant injuries, safety concerns, harassment and EEO.

- Proactively counsel and advise employees in a broad range of employee relations issues and information practices to ensure a positive and productive work environment.

- Advise management on day-to-day employee relations issues to prevent them from escalating to highly visible and costly employee concerns and litigations.

- Develop, implement and modify administrative processes and programs to assist in the effective management of personnel issues such as Overtime Justification, Return to Work and Salary Continuance During Absences.

- Provide guidance and support in the development of program staffing plans pursuant to programmatic requirements initiated by the Defense Nuclear Facilities Safety Board (DNFSB), the Tri-Party Agreement and other potential third-parties.

- Provide input to organizational structure. Assist in the preparation of job descriptions, resolution of compensation issues and appropriate placement of personnel. In addition, provide guidance to managers in meeting EEO special placement goals.

- Develop programs aimed at improving productivity and workforce efficiency. 


\section{MAJOR ACTIVITIES PERFORMED TO DELIVER PRODUCTS AND SERVICES (continued)}

- Develop and deliver targeted skill enhancement programs including, but not limited to, Standards of Conduct Administration, New Managers' Orientation, and Labor Agreement Administration.

- Assist management in succession planning and the implementation of appropriate development plans and specialized training requirements to ensure assignment readiness.

\section{PRODUCTS/SERVICES PROVIDED}

- Employee/Labor Relations Council

- Administer and interpret Collective Bargaining Agreements with HAMTC and HGU.

- Initiate and revise HR Management Requirements and Practices

- Develop strategic bargaining plans

- Site Management System (SMS) Reporting/Site Support Program Plan (SSPP)

- Develop and deliver Skill Enhancement Programs

- Special Requests

- Counsel and documentation for High Profile Case Management

- Benchmark HR best practices

\section{EVALUATION OF MAJOR ACTIVITIES (COST, VALUE-ADDED, ETC.)}

- Advising management on day-to-day employee relations issues to prevent them from escalating to highly visible and costly employee concerns and litigations. Avoids costly preparation and settlement of EEOC and Human Rights. Commission charges and litigations.

- Providing input to organizational structure. Helps managers meet EEO requirements and special placement goals.

- Effectively administering the Salary Continuance Program to reduce absenteeism and significantly improve productivity.

- Resolving day-to-day union problems. Avoids the costs associated with formal grievances $(\$ 5,000-\$ 10,000$ in hearing costs with settlements having the potential for reaching $\$ 250,000+)$.

- Utilization of the Craft Alignment Program and Temporary Employee Provisions of the Collective Bargaining Agreement. These programs increase the efficiency of our operations and have a direct impact in cost savings. 
EVALUATION OF MAJOR ACTIVITIES (COST, VALUE-ADDED, ETC.) (continued)

- Establishing certification programs with the unions--such as Nuclear Process Operator, Health Physics Technician and Power Operator programs which are essential to meet regulatory requirements such as the (DNFSB) and DOE Orders.

- Negotiating alcohol testing with the unions to meet CDL and PSAP requirements. These are mandated by federal regulations or agencies such as the DNFSB, Department of Transportation and $\mathrm{RL}$.

- Providing the lead role for Hanford site contractors regarding the Collective Bargaining Agreements with HAMTC and HGU. These agreements are legally binding obligations and provide the sole basis for work practice modifications involving unionized employees.

- Working in conjunction with the labor counsel providing support in preparation for responding to NLRB charges and litigations. Provide expert witness testimony as to facts and circumstances. Inappropriate preparation may have a significant financial and/or operational impact on the Company.

- Providing advice and counsel to KEH and BHI regarding Labor/Employee Relations issues. Ensures site-wide consistency in interpretation and application of the Collective Bargaining Agreement and HR policies and practices as they relate to transitional issues. This consistency results in cost avoidance for KEH and BHI as well as internally for WHC.

\section{FACTORS WHICH INFLUENCE RESOURCE CONSUMPTION (CHANGES TO COST AND VOLUME)}

- Special requests from WHC management, RL HRD, HAMTC and HGU leadership produce an inability to plan resources for these requests versus routine work activities.

- Reduced budgets have resulted in reductions to staff.

- Reductions and realignment of staff with associated learning curves influence turnaround on requests. 


\section{FACTORS THAT INFLUENCE CHANGES IN TYPES OR NATURE OF PRODUCTS and SERVICES}

- Developing alternative processes for increased productivity and reduction of costs to be proposed in the Collective Bargaining Agreements.

- Federal or state legislation changes.

- Legal or regulatory rulings that significantly change prevailing business practices.

- Clarification/understanding of customers' needs (interrelationships, etc.)

- Meeting requirements and expectations of Contract Reform.

Summary of Customer Requirements (Needs)

- Compliance with all federal, state and DOE regulatory requirements

- Labor stability

- Timely and equitable resolution of employee concerns

\section{OTHER EXTERNAL CHALLENGES}

- Provide assistance to other-contractors.

- Internal WHC and external RL organizational changes impact the effectiveness of maintaining clear lines of communication.

- Requirements of external stakeholders. 


\section{GOALS AND OBJECTIVES}

\section{General Priorities - Budget}

1. Conduct Company business within the legally binding framework of collective bargaining agreements with our unions and adhere to federal and state laws impacting those relationships.

2. Direct the operations of the matrixed HR Staff Relations offices.

3. Serve as the focal point for management and employees in the administration of HR policies/ procedures and the resolution of employee concerns and issues.

4. Provide advice and counsel to management in the interpretation/application of employee and labor relations policies, procedures and practices, including administration of the Standards of Conduct.

5. Provide information and interpretation for all employees regarding Company-wide HR policies.

6. Administer HR programs in a consistent and fair manner to achieve and maintain positive employee morale which motivates superior performance.

7. Administer union agreements and provide advice/counsel to management regarding all aspects of labor relations policies and issues.

8. Counsel with senior staff and other upper level management to ensure timely and informed response regarding a broad spectrum of sensitive HR issues. 


\begin{tabular}{|c|c|c|c}
\hline & Westinghouse Hanford Company \\
Program Title & SMS/WBS No. & $\begin{array}{c}\text { FY } 1995 \\
\text { Site Support Program Plan } \\
\text { Date Prepared: }\end{array}$ \\
\hline
\end{tabular}

\section{General Priorities - General}

1. Conduct all operations in a safe and cost-effective manner.

2. Meet RL HR Division requirements and commitments.

3. Manage all activities in a total quality manner.

4. Negotiate, interpret and administer collective bargaining agreements.

5. Implement compliance programs.

6. Coordinate employee resolution programs.

7. Ensure fair, consistent and equal treatment of employees.

8. Develop, communicate and implement HR policies and procedures.

9. Maintain labor stability.

10. Manage cultural and climate activities to develop and improve employee working relationships at all levels of the organization. 


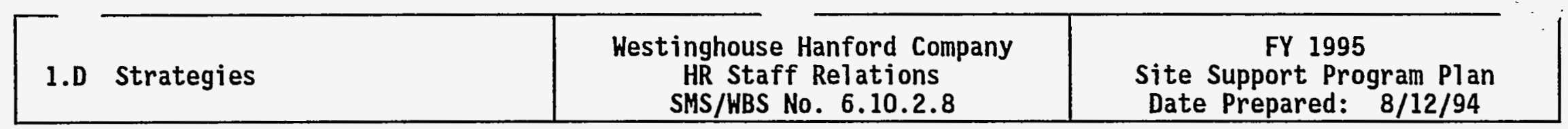

\section{CUSTOMER SUPPORT STRATEGIES}

Based upon reality of reduced staff levels, put emphasis on management development and leadership training. Review organizational staff mix to align skills/strengths with work.

\section{ORGANIZATION and MANAGEMENT STRATEGIES}

Determine staff levels based upon outcome of organizational changes resulting from contract reform, internal WHC restructuring, ICF KH/WHC integration, BHI transition, and the ability to provide alternative methods for performing work. 


\begin{tabular}{ll|c|c|c}
\hline & Westinghouse Hanford Company & $\begin{array}{c}\text { FY 1995 } \\
\text { HR Staff Relations } \\
\text { SMS/WBS No.6.10.2.8 }\end{array}$ & $\begin{array}{c}\text { Site Support Program Plan } \\
\text { Date Prepared: } 8 / 12 / 94\end{array}$ \\
\hline
\end{tabular}

\section{ASSUMPTIONS}

- All employee and labor relations activities must fall within parameters established by federal and state laws, labor agreements, and other legal and regulatory requirements.

- Interpretations and decisions must balance business needs with employee needs within the framework of identified policies, procedures and sound professional practices. 


\section{ISSUES AND CONSTRAINTS}

- The Five-Year Plan and the Multi-Year Program Plan are excluded from the requirements set forth in the WBS unless otherwise noted.

- The specific regulations directing drug testing specify that there will be implementation of the rules no later than one year from commencement of impact bargaining.

- Activities must comply with current applicable regulations and guidance:

- Federal/State/etc., Regulations

- DOE Contract

- DOE Orders and Directives

- DOE/RL Guidance/Correspondence

- Labor Contract

- WHC Management Guidance

- Management Requirements and Procedures (MRP), Company Policies, and Other Controlled Manuals

- The total impact of the Environmental Restoration Contractor is as yet unknown. 


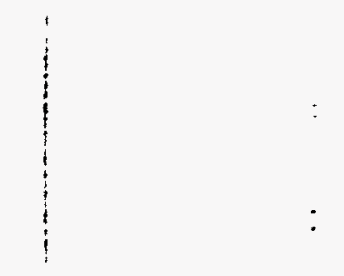

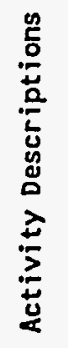




\begin{tabular}{|c|c|}
\hline 2.A.2 Description of Activities & $\begin{array}{l}\text { Westinghouse Hanford Company } \\
\text { HR Staff Relations } \\
\text { SMS/WBS No. 6.10.2.8 }\end{array}$ \\
\hline ACTIVITY & DESCRIPTIION \\
\hline $\begin{array}{l}\frac{49000}{\text { Relations Management }} \\
(1 \mathrm{Ex} ; 1 \mathrm{Nx})\end{array}$ & $\begin{array}{l}\text { - This activity includes providing support to WHC management in } \\
\text { establishing and achieving Company HR goals, generally, and more } \\
\text { specifically, as they apply to employee/labor relations. } \\
\text { - Direct the operations of the matrixed HR Staff Relations offices } \\
\text { and provide functional control/guidance to management with regard } \\
\text { to the administration and application of HR policies, } \\
\text { procedures, programs and practices. }\end{array}$ \\
\hline \multirow[t]{3}{*}{$\begin{array}{c}49100 \text { - Support Program/Project } \\
\text { Level Organizations } \\
(1.1 \mathrm{Ex} ; .3 \mathrm{Nx}) \\
\end{array}$} & $\begin{array}{l}\text { - Ensure appropriate HR policies are current through developing new } \\
\text { policies or making timely revisions in concert with cognizant } \\
\text { HR functions. }\end{array}$ \\
\hline & $\begin{array}{l}\text { - Work directly with WHC management and HR functions in support of } \\
\text { achieving the company goal of improved employee relations with } \\
\text { all employees and providing fulT-service HR support. }\end{array}$ \\
\hline & $\begin{array}{l}\text { - Provide a centralized focus for efficient administrative support } \\
\text { of the activities of the HR Staff Relations' matrixed } \\
\text { organizations. }\end{array}$ \\
\hline $\begin{array}{l}\underline{49100} \text { - Labor Relations } \\
\text { (.8 Ex; } 1 \mathrm{Nx} ; .8 \mathrm{Nx} \text { Temp Labor) } \\
\text { See milestone: } 23\end{array}$ & $\begin{array}{l}\text { - Day-to-day administration of the Collective Bargaining Agreement. } \\
\text { - Negotiate collective bargaining agreements and other special } \\
\text { agreements and understandings with HAMTC/HGU. } \\
\text { - Communicate with RL on a broad range of labor relations issues. } \\
\text { - Package and communicate management expectations regarding key } \\
\text { business decisions including, but not limited to, changes in work } \\
\text { scope, skills mix, and training requirements for bargaining unit } \\
\text { employees. }\end{array}$ \\
\hline $\begin{array}{l}\text { Contract Administration } \\
\qquad(1 \mathrm{Ex} ; 1 \mathrm{Nx})\end{array}$ & $\begin{array}{l}\text { - Interface with union leadership, international union } \\
\text { representatives, RL and other federal agencies such as DOL. } \\
\text { - Provide counsel and advice to the matrixed HR Staff Relations } \\
\text { offices and management at large. } \\
\text { - Ensure contractual provisions are followed for all negotiated } \\
\text { agreements reached with HAMTC/HGU. }\end{array}$ \\
\hline
\end{tabular}




\begin{tabular}{|c|c|}
\hline 2.A.2 Description of Activities & $\begin{array}{l}\text { Westinghouse Hanford Company } \\
\text { HR Staff Relations } \\
\text { SMS/WBS No. } 6.10 .2 .8 \\
\end{array}$ \\
\hline ACTIVITY & DESCRIPTION \\
\hline $\begin{array}{l}\text { Educational Programs } \\
\qquad(.2 \mathrm{Ex} ; .1 \mathrm{Nx})\end{array}$ & $\begin{array}{l}\text { - Prepare and deliver skill enhancement programs for managers } \\
\text { relative to rights and responsibilities of managing a represented } \\
\text { workforce including labor agreement interpretation and } \\
\text { administration. } \\
\text { - Orient and counsel managers on provisions of the Collective } \\
\text { Bargaining Agreement and significant changes in labor law } \\
\text { impacting management of the represented workforce. }\end{array}$ \\
\hline $\begin{array}{l}\text { Craft Alignment Program } \\
\qquad(.2 \mathrm{Ex})\end{array}$ & $\begin{array}{l}\text { - Increase flexibility and optimize labor resources in a mutually } \\
\text { beneficial manner to produce a working environment which is } \\
\text { safer, more efficient and more economical. }\end{array}$ \\
\hline $\begin{array}{l}\text { Joint Committee on .Labor Management } \\
\text { Affairs } \\
\qquad(.3 \mathrm{Ex} ; .1 \mathrm{Nx})\end{array}$ & $\begin{array}{l}\text { - Twenty-two members of WHC management and twenty-two members of } \\
\text { labor jointly endeavor to develop a collective working } \\
\text { environment wherein efficiency and effectiveness are paramount. } \\
\text { This working environment will have a positive impact on } \\
\text { containing the cost of grievance/arbitration resolution and } \\
\text { improve productivity. }\end{array}$ \\
\hline $\begin{array}{l}\underline{49200} \text { - Staff Relations/Transition } \\
\text { Projects } \\
(.4 \mathrm{Ex} ; .4 \mathrm{Nx}) \\
\text { See milestone: } 20\end{array}$ & $\begin{array}{l}\text { - Provide HR services to line management on a daily basis. Assist } \\
\text { in problem resolution. Provide functional control/guidance to } \\
\text { management with regard to the administration and application of } \\
\text { HR policies, procedures, programs and practices. Maintain open } \\
\text { communications with employees and management on all employee- } \\
\text { related issues. }\end{array}$ \\
\hline $\begin{array}{l}\text { Labor Relations } \\
(.6 \mathrm{Ex} ; .2 \mathrm{Nx}) \\
\text { See milestones: } 21 \& 22\end{array}$ & $\begin{array}{l}\text { - Provide administrative application of the Collective Bargaining } \\
\text { Agreement and work toward minimization of grievances and third- } \\
\text { party resolutions. } \\
\text { - Provide guidance to line management in the preparation of Step I } \\
\text { and II grievance answers. Actively participate in Step III } \\
\text { grievance meetings and prepare draft answers for assigned cases. } \\
\text { - Provide support to the Office of General Counsel in } \\
\text { arbitration/litigation matters. }\end{array}$ \\
\hline
\end{tabular}




\begin{tabular}{|c|c|}
\hline 2.A.2 Description of Activities & $\begin{array}{c}\text { Hestinghouse Hanford Company } \\
\text { HR Staff Relations } \\
\text { SMS/WBS No. 6.10.2.8 } \\
\end{array}$ \\
\hline ACTIVITY & DESCRIPTION \\
\hline $\begin{array}{l}\text { Wage and Salary Administration } \\
\qquad(.2 \mathrm{Ex})\end{array}$ & $\begin{array}{l}\text { - Work with WHC Compensation Services to create innovative } \\
\text { approaches to resolve pay issues, delivery and recognition } \\
\text { programs. Provide line management support in the preparation and } \\
\text { preliminary review of merit plans. }\end{array}$ \\
\hline $\begin{array}{l}\text { Benefits } \\
(.2 \mathrm{Ex})\end{array}$ & $\begin{array}{l}\text { - Work with Benefits Administration to provide information and/or } \\
\text { assistance relative to employee benefit questions or concerns. } \\
\text { Communicate with employees and management on emerging benefit } \\
\text { issues. }\end{array}$ \\
\hline $\begin{array}{l}\text { Equal Employment Opportunities/ } \\
\text { Affirmative Action } \\
\qquad(.2 \text { Ex) }\end{array}$ & $\begin{array}{l}\text { - Work proactively with line management to meet diversity goals. } \\
\text { Provide direct intervention in discrimination/harassment claims } \\
\text { to minimize formal complaints, concerns, or third-party } \\
\text { resolutions. }\end{array}$ \\
\hline $\begin{array}{l}\text { Organizational Development } \\
\qquad(.2 \mathrm{Ex})\end{array}$ & $\begin{array}{l}\text { - Provide organizational effectiveness input to line management and } \\
\text { skill enhancement training to optimize managerial efficiency and } \\
\text { effectiveness in dealing with employee and labor relations } \\
\text { issues. }\end{array}$ \\
\hline $\begin{array}{l}\text { Employment } \\
\qquad(.2 \text { Ex) }\end{array}$ & $\begin{array}{l}\text { - Assist in the recruiting and transferring of personnel in the } \\
\text { exempt, non-exempt and represented classifications. Coordinate } \\
\text { flow of paperwork within the program/project and the Central } \\
\text { Employment Office. }\end{array}$ \\
\hline $\begin{array}{c}\text { Maintain a Safe Work Environment } \\
\qquad(.2 \text { Ex) }\end{array}$ & $\begin{array}{l}\text { - Directly contribute to the resolution of safety, health and } \\
\text { environmental issues as appropriate. Refer unresolved issues to } \\
\text { management. Rotate participation in the Safety Observer Program } \\
\text { among staff members. }\end{array}$ \\
\hline $\begin{array}{l}\text { Displaced Employees/Manpower } \\
\text { Adjustments } \\
\text { (.2 Ex) }\end{array}$ & $\begin{array}{l}\text { - Directly assist with the identification and disposition of } \\
\text { displaced workers. Provide guidance concerning union contract } \\
\text { adherence, inter-HR coordination of job placement, career } \\
\text { counseling, resume preparation and training as required. }\end{array}$ \\
\hline
\end{tabular}




\begin{tabular}{|c|c|}
\hline 2.A.2 Description of Activities & $\begin{array}{l}\text { Westinghouse Hanford Company } \\
\text { HR Staff Relations } \\
\text { SMS/WBS No. } 6.10 .2 .8\end{array}$ \\
\hline ACTIVITY & DESCRIPTION \\
\hline $\begin{array}{l}49300 \text { - Staff Relations/Emergency, } \\
\text { Safety and Quality Services } \\
(.6 \mathrm{Ex} ; .6 \mathrm{Nx})\end{array}$ & $\begin{array}{l}\text { - Provide HR services to line management on a daily basis. Assist } \\
\text { in problem resolution. Provide functional control/guidance to } \\
\text { management with regard to the administration and application of } \\
\text { HR policies, procedures, programs and practices. Maintain open } \\
\text { communications with employees and management on all employee- } \\
\text { related issues. }\end{array}$ \\
\hline $\begin{array}{l}\text { Labor Relations } \\
\qquad(1.0 \mathrm{Ex} ; 2 \mathrm{Nx})\end{array}$ & $\begin{array}{l}\text { - Provide administrative application of the Collective Bargaining } \\
\text { Agreement and work toward minimization of grievances and third- } \\
\text { party resolutions. } \\
\text { - Provide guidance to } 1 \text { ine management in the preparation of Step I } \\
\text { and II grievance answers. Actively participate in Step III } \\
\text { grievance meetings and prepare draft answers for assigned cases. } \\
\text { - Provide support to the Office of General Counsel in } \\
\text { arbitration/litigation matters. }\end{array}$ \\
\hline $\begin{array}{l}\text { Wage and Salary Administration } \\
\qquad(.2 \text { Ex })\end{array}$ & $\begin{array}{l}\text { - Work with WHC Compensation Services to create innovative } \\
\text { approaches to resolve pay issues, delivery and recognition } \\
\text { programs. Provide line management support in the preparation and } \\
\text { preliminary review of merit plans. }\end{array}$ \\
\hline $\begin{array}{l}\text { Benefits } \\
(.2 \text { Ex) }\end{array}$ & $\begin{array}{l}\text { - Work with Benefits Administration to provide information and/or } \\
\text { assistance relative to employee benefit questions or concerns. } \\
\text { Communicate with employees and management on emerging benefit } \\
\text { issues. }\end{array}$ \\
\hline $\begin{array}{l}\text { Equal Employment } \\
\text { Opportunities/Affirmative Action } \\
\qquad(.2 \mathrm{Ex}) \\
\end{array}$ & $\begin{array}{l}\text { - Work proactively with line management to meet diversity goals. } \\
\text { Provide direct intervention in discrimination/harassment claims } \\
\text { to minimize formal complaints, concerns, or third-party } \\
\text { resolutions. }\end{array}$ \\
\hline $\begin{array}{l}\text { Organizational Development } \\
\qquad(.2 \mathrm{Ex})\end{array}$ & $\begin{array}{l}\text { - Provide.organizational effectiveness input to line management and } \\
\text { skill-enhancement training to optimize managerial efficiency and } \\
\text { effectiveness in dealing with employee and labor relations } \\
\text { issues. }\end{array}$ \\
\hline
\end{tabular}




\begin{tabular}{|c|c|}
\hline 2.A.2 Description of Activities & $\begin{array}{l}\text { Westinghouse Hanford Company } \\
\text { HR Staff Relations } \\
\text { SMS/WBS No. 6.10.2.8 }\end{array}$ \\
\hline ACTIVITY & DESCRIPTION \\
\hline $\begin{array}{l}\text { Employment } \\
\qquad(.2 \text { Ex })\end{array}$ & $\begin{array}{l}\text { - Assist in the recruiting and transferring of personnel in the } \\
\text { exempt, non-exempt, and represented classifications. Coordinate } \\
\text { flow of paperwork within the program/project and the Central } \\
\text { Employment office. }\end{array}$ \\
\hline $\begin{array}{l}\text { Maintain a Safe Work Environment } \\
\qquad(.2 \mathrm{Ex})\end{array}$ & $\begin{array}{l}\text { - Directly contribute to. the resolution of safety, health and } \\
\text { environmental issues as appropriate. Refer unresolved issues to } \\
\text { management. Rotate participation in the Safety Observer Program } \\
\text { among staff members. }\end{array}$ \\
\hline $\begin{array}{l}\text { Displaced Employees/Manpower } \\
\text { Adjustments } \\
\qquad(.2 \mathrm{Ex})\end{array}$ & $\begin{array}{l}\text { - Directly assist with the identification and disposition of } \\
\text { displaced workers. Provide guidance concerning union contract } \\
\text { adherence, inter-HR coordination of job placement, career } \\
\text { counseling, resume preparation and training as required. }\end{array}$ \\
\hline $\begin{array}{c}\underline{49400} \text { - Staff Relations/TWRS } \\
\text { (.6 Ex; .5 Nx) }\end{array}$ & $\begin{array}{l}\text { - Provide HR services to line management on a daily basis. Assist } \\
\text { in problem resolution. Provide functional control/guidance to } \\
\text { management with regard to the administration and application of } \\
\text { HR policies, procedures, programs and practices. Maintain open } \\
\text { communications with employees and management on all employee- } \\
\text { related issues. }\end{array}$ \\
\hline $\begin{array}{l}\text { Labor Relations } \\
(1.0 \mathrm{Ex} ; .2 \mathrm{Nx})\end{array}$ & $\begin{array}{l}\text { - Provide administrative application of the Collective Bargaining } \\
\text { Agreement and work toward minimization of grievances and third- } \\
\text { party resolutions. } \\
\text { - Provide guidance to line management in the preparation of Step I } \\
\text { and II grievance answers. Actively participate in Step III } \\
\text { grievance meetings and prepare draft answers for assigned cases. } \\
\text { - Provide support to the Office of General Counsel in } \\
\text { arbitration/litigation matters. }\end{array}$ \\
\hline $\begin{array}{l}\text { Wage and Salary Administration } \\
\qquad(.2 \text { Ex) }\end{array}$ & $\begin{array}{l}\text { - Work with WHC Compensation Services to create innovative } \\
\text { approaches to resolve pay issues, delivery and recognition } \\
\text { programs. Provide line management support in the preparation and } \\
\text { preliminary review of merit plans. }\end{array}$ \\
\hline
\end{tabular}




\begin{tabular}{|c|c|}
\hline 2.A.2 Description of Activities & $\begin{array}{l}\text { Westinghouse Hanford Company } \\
\text { HR Staff Relations } \\
\text { SMS/WBS No. 6.10.2.8 }\end{array}$ \\
\hline ACTIVITY & DESCRIPTION \\
\hline $\begin{array}{l}\text { Benefits } \\
(.2 \mathrm{Ex})\end{array}$ & $\begin{array}{l}\text { - Work with Benefits Administration to provide information and/or } \\
\text { assistance relative to employee benefit questions or concerns. } \\
\text { Communicate with employees and management on emerging benefit } \\
\text { issues. }\end{array}$ \\
\hline $\begin{array}{l}\text { Equal Employment } \\
\text { Opportunities/Affirmative Action } \\
(.2 \mathrm{Ex})\end{array}$ & $\begin{array}{l}\text { - Work proactively with line management to meet diversity goals. } \\
\text { Provide direct intervention in discrimination/harassment claims } \\
\text { to minimize formal complaints, concerns, or third-party } \\
\text { resolutions. }\end{array}$ \\
\hline $\begin{array}{l}\text { Organizational Development } \\
\qquad(.2 \mathrm{Ex})\end{array}$ & $\begin{array}{l}\text { - Provide organizational effectiveness input to line management and } \\
\text { skill-enhancement training to optimize managerial efficiency and } \\
\text { effectiveness in dealing with employee and labor relations } \\
\text { issues. }\end{array}$ \\
\hline $\begin{array}{l}\text { Employment } \\
\qquad(.2 \text { Ex) }\end{array}$ & $\begin{array}{l}\text { - Assist in the recruiting and transferring of personnel in the } \\
\text { exempt, non-exempt, and represented classifications. Coordinate } \\
\text { flow of paperwork within the program/project and the Central } \\
\text { Employment office. }\end{array}$ \\
\hline $\begin{array}{l}\text { Maintain a Safe Work Environment } \\
\qquad(.2 \text { Ex) }\end{array}$ & $\begin{array}{l}\text { - Directly contribute to the resolution of safety, health and } \\
\text { environmental issues as appropriate. Refer unresolved issues to } \\
\text { management. Rotate participation in the Safety Observer Program } \\
\text { among staff members. }\end{array}$ \\
\hline $\begin{array}{l}\text { Displaced Employees/Manpower } \\
\text { Requirements } \\
(.2 \mathrm{Ex})\end{array}$ & $\begin{array}{l}\text { - Directly assist with the identification and disposition of } \\
\text { displaced workers. Provide guidance concerning union contract } \\
\text { adherence, inter-HR coordination of job placement, career } \\
\text { counseling, resume preparation and training as required. }\end{array}$ \\
\hline $\begin{array}{l}\frac{49500}{\text { Administration }} \text { - Staff Relations/ } \\
(.3 \text { Ex; } .4 \mathrm{Nx}) \\
\text { See milestone: } 25\end{array}$ & $\begin{array}{l}\text { - Provide HR services to line management on a daily basis. Assist } \\
\text { in problem resolution. Provide functional control/guidance to } \\
\text { management with regard to the administration and application of } \\
\text { HR policies, procedures, programs and practices. Maintain open } \\
\text { communications with employees and management on all employee- } \\
\text { related issues. }\end{array}$ \\
\hline
\end{tabular}




\begin{tabular}{|c|c|}
\hline 2.A.2 Description of Activities & $\begin{array}{l}\text { Westinghouse Hanford Company } \\
\text { HR Staff Relations } \\
\text { SMS/HBS No. } 6.10 .2 .8 \\
\end{array}$ \\
\hline ACTIVITY & DESCRIPTION \\
\hline $\begin{array}{l}\text { Labor Relations } \\
(1.0 \mathrm{Ex} ; .2 \mathrm{Nx} ; \\
.1 \mathrm{Nx} \text { Temporary Labor) }\end{array}$ & $\begin{array}{l}\text { - Provide administrative application of the Collective Bargaining } \\
\text { Agreement and work toward minimization of grievances and third- } \\
\text { party resolutions. } \\
\text { - Provide guidance to line management in the preparation of Step I } \\
\text { and II grievance answers. Actively participate in Step III } \\
\text { grievance meetings and prepare draft answers for assigned cases. } \\
\text { - Provide support to the Office of General Counsel in } \\
\text { arbitration/litigation matters. }\end{array}$ \\
\hline $\begin{array}{l}\text { Wage and Salary Administration } \\
\qquad(.2 \text { Ex) }\end{array}$ & $\begin{array}{l}\text { - Work with WHC Compensation Services to create innovative } \\
\text { approaches to resolve pay issues, delivery and recognition } \\
\text { programs. Provide line management support in the preparation and } \\
\text { preliminary review of merit plans. }\end{array}$ \\
\hline $\begin{array}{l}\text { Benefits } \\
(.2 \text { Ex) }\end{array}$ & $\begin{array}{l}\text { - Work with Benefits Administration to provide information and/or } \\
\text { assistance relative to employee benefit questions or concerns. } \\
\text { Communicate with employees and management on emerging benefit } \\
\text { issues. }\end{array}$ \\
\hline $\begin{array}{l}\text { Equal Employment Opportunities/ } \\
\text { Affirmative Action } \\
(.2 \text { Ex) }\end{array}$ & $\begin{array}{l}\text { - Work proactively with line management to meet diversity goals. } \\
\text { Provide direct intervention in discrimination/harassment claims } \\
\text { to minimize formal complaints, concerns, or third-party } \\
\text { resolutions. }\end{array}$ \\
\hline $\begin{array}{l}\text { Organizational Development } \\
\qquad(.2 \mathrm{Ex})\end{array}$ & $\begin{array}{l}\text { - Provide organizational effectiveness input to line management and } \\
\text { skill enhancement training to optimize managerial efficiency and } \\
\text { effectiveness in dealing with employee and Tabor relations } \\
\text { issues. }\end{array}$ \\
\hline $\begin{array}{l}\text { Employment } \\
\qquad(.2 \text { Ex) }\end{array}$ & $\begin{array}{l}\text { - Assist in the recruiting and transferring of personnel in the } \\
\text { exempt, non-exempt and represented classifications. Coordinate } \\
\text { flow of paperwork within the program/project and the Central } \\
\text { Employment Office. }\end{array}$ \\
\hline $\begin{array}{l}\text { Maintain a Safe Work Environment } \\
\qquad(.2 \text { Ex })\end{array}$ & $\begin{array}{l}\text { - Directly contribute to the resolution of safety, health and } \\
\text { environmental issues as appropriate. Refer unresolved issues to } \\
\text { management. Rotate participation in the Safety Observer Program } \\
\text { among staff members. }\end{array}$ \\
\hline
\end{tabular}




\begin{tabular}{|c|c|}
\hline 2.A.2 Description of Activities & $\begin{array}{l}\text { Westinghouse Hanford Company } \\
\text { HR Staff Relations } \\
\text { SMS/WBS No. 6.10.2.8 }\end{array}$ \\
\hline ACTIVITY & DESCRIPTION \\
\hline $\begin{array}{l}\text { Displaced Employees/Manpower } \\
\text { Adjustments } \\
(.2 \mathrm{Ex})\end{array}$ & $\begin{array}{l}\text { - Directly assist with the identification and disposition of } \\
\text { displaced workers. Provide guidance concerning union contract } \\
\text { adherence, inter-HR coordination of job placement, career } \\
\text { counseling, resume preparation and training as required. }\end{array}$ \\
\hline $\begin{array}{l}49600 \text { - Staff Relations/Spent } \\
\text { Nuclear Fuels } \\
\text { (.3 Ex; } .4 \mathrm{Nx}) \\
\text { See milestone: } 24 \\
\end{array}$ & $\begin{array}{l}\text { - Provide HR services to line management on a daily basis. Assist } \\
\text { in problem resolution. Provide functional control/guidance to } \\
\text { management with regard to the administration and application of } \\
\text { HR policies, procedures, programs and practices. Maintain open } \\
\text { communications with employees and management on all employee- } \\
\text { related issues. }\end{array}$ \\
\hline $\begin{array}{l}\text { Labor Relations } \\
(1.0 \mathrm{Ex} ; .2 \mathrm{Nx} \\
.1 \text { Nx Temporary Labor) }\end{array}$ & $\begin{array}{l}\text { - Provide administrative application of the Collective Bargaining } \\
\text { Agreement and work toward minimization of grievances and third- } \\
\text { party resolutions. } \\
\text { - Provide guidance to line management in the preparation of Step I } \\
\text { and II grievance answers. Actively participate in Step III } \\
\text { grievance meetings and prepare draft answers for assigned cases. } \\
\text { - Provide support to the office of General Counsel in } \\
\text { arbitration/litigation matters. }\end{array}$ \\
\hline $\begin{array}{l}\text { Wage and Salary Administration } \\
\qquad(.2 \text { Ex) }\end{array}$ & $\begin{array}{l}\text { - Work with WHC Compensation Services to create innovative } \\
\text { approaches to resolve pay issues, delivery and recognition } \\
\text { programs. Provide line management support in the preparation and } \\
\text { preliminary review of merit plans. }\end{array}$ \\
\hline $\begin{array}{l}\text { Benefits } \\
\text { (.2 Ex) }\end{array}$ & $\begin{array}{l}\text { - Work with Benefits Administration to provide information and/or } \\
\text { assistance relative to employee benefit questions or concerns. } \\
\text { Communicate with employees and management on emerging benefit } \\
\text { issues. }\end{array}$ \\
\hline $\begin{array}{l}\text { Equal Employment Opportunities/ } \\
\text { Affirmative Action } \\
\qquad(.2 \mathrm{Ex})\end{array}$ & $\begin{array}{l}\text { - Work proactively with line management to meet diversity goals. } \\
\text { Provide direct intervention in discrimination/harassment claims } \\
\text { to minimize formal complaints, concerns, or third-party } \\
\text { resolutions. }\end{array}$ \\
\hline
\end{tabular}




\begin{tabular}{|c|c|}
\hline 2.A.2 Description of Activities & $\begin{array}{l}\text { Westinghouse Hanford Company } \\
\text { HR Staff Relations } \\
\text { SMS/WBS No. 6.10.2.8 }\end{array}$ \\
\hline ACTIVITY & DESCRIPTION \\
\hline $\begin{array}{l}\text { Organizational Development } \\
\qquad(.2 \mathrm{Ex})\end{array}$ & $\begin{array}{l}\text { - Provide organizational effectiveness input to line management and } \\
\text { skill enhancement training to optimize managerial efficiency and } \\
\text { effectiveness in dealing with employee and labor relations } \\
\text { issues. }\end{array}$ \\
\hline $\begin{array}{l}\text { Employment } \\
\qquad(.2 \text { Ex) }\end{array}$ & $\begin{array}{l}\text { - Assist in the recruiting and transferring of personnel in the } \\
\text { exempt, non-exempt, and represented classifications. Coordinate } \\
\text { flow of paperwork within the program/project and the Central } \\
\text { Employment office. }\end{array}$ \\
\hline $\begin{array}{l}\text { Maintain a Safe Work Environment } \\
\qquad(.2 \text { Ex })\end{array}$ & $\begin{array}{l}\text { - Directly contribute to the resolution of safety, health and } \\
\text { environmental issues as appropriate. Refer unresolved issues to } \\
\text { management. Rotate participation in the Safety Observer Program } \\
\text { among staff members. }\end{array}$ \\
\hline $\begin{array}{l}\text { Displaced Employees/Manpower } \\
\text { Adjustments } \\
(.2 \text { Ex })\end{array}$ & $\begin{array}{l}\text { - Directly assist with the identification and disposition of } \\
\text { displaced workers. Provide guidance concerning union contract } \\
\text { adherence, inter-HR coordination of job placement, career } \\
\text { counseling, resume preparation and training as required. }\end{array}$ \\
\hline $\begin{array}{c}\frac{49700}{\text { Analytical \& Environmental Services }} \\
(.6 \text { Ex; } .5 \mathrm{Nx})\end{array}$ & $\begin{array}{l}\text { - Provide HR services to line management on a daily basis. Assist } \\
\text { in problem resolution. Provide functional control/guidance to } \\
\text { management with regard to the administration and application of } \\
\text { HR policies, procedures, programs and practices. Maintain open } \\
\text { communications with employees and management on all employee } \\
\text { related issues. }\end{array}$ \\
\hline $\begin{array}{l}\text { Labor Relations } \\
(.6 \mathrm{Ex} ; .1 \mathrm{Nx}) \\
\text { See milestones: } 26 \& 27\end{array}$ & $\begin{array}{l}\text { - Provide administrative application of the Collective Bargaining } \\
\text { Agreement and work toward minimization of grievances and third- } \\
\text { party resolutions. } \\
\text { - Provide guidance to line management in the preparation of Step I } \\
\text { and II grievance answers. Actively participate in Step III } \\
\text { grievance meetings and prepare draft answers for assigned cases. } \\
\text { - Provide support to the Office of General Counsel in } \\
\text { arbitration/litigation matters. }\end{array}$ \\
\hline
\end{tabular}




\begin{tabular}{|c|c|}
\hline 2.A.2 Description of Activities & $\begin{array}{l}\text { Westinghouse Hanford Company } \\
\text { HR Staff Relations } \\
\text { SMS/WBS No. } 6.10 .2 .8\end{array}$ \\
\hline ACTIVITY & DESCRIPTION \\
\hline $\begin{array}{l}\text { Wage and Salary Administration } \\
\qquad(.2 \mathrm{Ex})\end{array}$ & $\begin{array}{l}\text { - Work with WHC Compensation Services to create innovative } \\
\text { approaches to resolve pay issues, delivery and recognition } \\
\text { programs. Provide line management support in the preparation and } \\
\text { preliminary review of merit plans. }\end{array}$ \\
\hline $\begin{array}{l}\text { Benefits } \\
(.2 \text { Ex })\end{array}$ & $\begin{array}{l}\text { - Work with Benefits Administration to provide information and/or } \\
\text { assistance relative to employee benefit questions or concerns. } \\
\text { Communicate with employees and management on emerging benefit } \\
\text { issues. }\end{array}$ \\
\hline $\begin{array}{l}\text { Equal Employment } \\
\text { Opportunities/Affirmative Action } \\
(.2 \mathrm{Ex})\end{array}$ & $\begin{array}{l}\text { - Work proactively with } 1 \text { ine management to meet diversity goals. } \\
\text { Provide direct intervention in discrimination/harassment claims } \\
\text { to minimize formal complaints, concerns, or third-party } \\
\text { resolutions. }\end{array}$ \\
\hline $\begin{array}{l}\text { Organizational Development } \\
\qquad(.2 \mathrm{EX})\end{array}$ & $\begin{array}{l}\text { - Provide organizational effectiveness input to line management and } \\
\text { skill enhancement training to optimize managerial efficiency and } \\
\text { effectiveness in dealing with employee and labor relations } \\
\text { issues. }\end{array}$ \\
\hline $\begin{array}{l}\text { Employment } \\
\qquad(.2 \text { Ex) }\end{array}$ & $\begin{array}{l}\text { - Assist in the recruiting and transferring of personnel in the } \\
\text { exempt, non-exempt and represented classifications. Coordinate } \\
\text { flow of paperwork within the program/project and the Central } \\
\text { Employment office. }\end{array}$ \\
\hline $\begin{array}{l}\text { Maintain a Safe Work Environment } \\
\qquad(.2 \text { Ex) }\end{array}$ & $\begin{array}{l}\text { - Directly contribute to the resolution of safety, health and } \\
\text { environmental issues as appropriate. Refer unresolved issues to } \\
\text { management. Rotate participation in the Safety Observer Program } \\
\text { among staff members. }\end{array}$ \\
\hline $\begin{array}{l}\text { Displaced Employees/Manpower } \\
\text { Adjustments } \\
(.2 \text { Ex) }\end{array}$ & $\begin{array}{l}\text { - Directly assist with the identification and disposition of } \\
\text { displaced workers. Provide guidance concerning union contract } \\
\text { adherence, inter-HR coordination of job placement, career } \\
\text { counseling, resume preparation and training as required. }\end{array}$ \\
\hline
\end{tabular}




\begin{tabular}{|c|c|c|c|c|c|c|c|c|}
\hline \multicolumn{4}{|c|}{ Full-Time Equivalent Staff by Job Description } & \multicolumn{5}{|c|}{ NOTE: Job Family Only After 1996} \\
\hline JOQB FAMILY & (n) & & & & & & & \\
\hline Job category & 1994 & 1995 & 1996 & 1997 & 1998 & 1999 & 2000 & 2001 \\
\hline$\therefore \because \cdots$ & $\begin{array}{lll}\because & \ddots & \cdots \\
\end{array}$ & . & & & & & . & \\
\hline First line & & 6.0 & 6.0 & 8.0 & 8.0 & 8.0 & 8.0 & 8.0 \\
\hline General/executive & & 2.0 & 2.0 & & & & & \\
\hline Project/Program & & & & & & & & \\
\hline other & & & & & & & & \\
\hline ENGINEERS $\quad$ Y & $\because$ & . & & & & & & \\
\hline Chemical & & & & & & & & \\
\hline Civil & & & & & & & & \\
\hline Computer & & & & & & & & \\
\hline Electrical & & & & & & & & \\
\hline Environmental & & & & & & & & \\
\hline Industrial & & & & & & & & \\
\hline Mechanical & & & & & & & & \\
\hline Nuclear & & & & & & & & \\
\hline Petroleum/Mining & & & & & & & & \\
\hline Plant & & & & & & & & \\
\hline Quality Control & & & & & & & & \\
\hline Safety & & & & & & & & \\
\hline other & & & & & & & & \\
\hline SCIENTISTS & & & & & & & & \\
\hline Chemists & & & & & & & & \\
\hline Environmental & & & & & & & & \\
\hline Geologists & & & & & & & & \\
\hline Life & & & & & & & & \\
\hline Material & & & & & & & & \\
\hline
\end{tabular}




\begin{tabular}{|c|c|c|c|c|c|c|c|c|}
\hline \multicolumn{4}{|c|}{ Full-Time Equivalent Staff by Job Description } & \multicolumn{5}{|c|}{ NOTE: Job Family Only After 1996} \\
\hline JDB FAM̆ILY & $\because$ & . & & & & & & \\
\hline Job category & 1994 & 1995 & 1996 & 1997 & 1998 & 1999 & 2000 & 2001 \\
\hline \multicolumn{9}{|l|}{ Mathematicians } \\
\hline \multicolumn{9}{|l|}{ Physicists } \\
\hline \multicolumn{9}{|l|}{ Social } \\
\hline \multicolumn{9}{|l|}{ other } \\
\hline ADMIN/OTHER PROFESSIONALS & $\because \because$ & & & 16.0 & 16.0 & 16.0 & 16.0 & $16.0^{\circ}$ \\
\hline \multicolumn{9}{|l|}{ Accountant/auditor } \\
\hline \multicolumn{9}{|l|}{ Architect } \\
\hline \multicolumn{9}{|l|}{ Buyers/procurement } \\
\hline \multicolumn{9}{|l|}{ Communications } \\
\hline \multicolumn{9}{|l|}{ Compl iance inspectors } \\
\hline \multicolumn{9}{|l|}{ Computer system Anal } \\
\hline \multicolumn{9}{|l|}{ Cost Est/planner/sch } \\
\hline \multicolumn{9}{|l|}{ Heal th Physics } \\
\hline \multicolumn{9}{|l|}{ Industrial Hygiene } \\
\hline \multicolumn{9}{|l|}{ Lawyers } \\
\hline Personnel/Labor Rela & & 15.0 & 15.0 & & & & & \\
\hline \multicolumn{9}{|l|}{ Physicians } \\
\hline \multicolumn{9}{|l|}{ Physician Assis/Nurs } \\
\hline \multicolumn{9}{|l|}{ Safeguard \& Security } \\
\hline \multicolumn{9}{|l|}{ Tech Writers \& Edit } \\
\hline \multicolumn{9}{|l|}{ Trainers } \\
\hline Other Temporary & & 1.0 & 1.0 & & & & & \\
\hline JOB FAMILY & & & & & & & & $\because:$ \\
\hline Job category & & & & & & & & \\
\hline GEN ADM/SECRETARY/CLERK & & & & & & & & \\
\hline
\end{tabular}




\begin{tabular}{|c|c|c|c|c|c|c|c|c|}
\hline \multicolumn{4}{|c|}{ Full-Time Equivalent Staff by Job Description } & \multicolumn{5}{|c|}{ NOTE: Job Family Only After 1996} \\
\hline JOB FAMILY & & & & & & & & \\
\hline Job category & 1994 & 1995 & 1996 & 1997 & 1998 & 1999 & 2000 & 2001 \\
\hline \multicolumn{9}{|l|}{ Admin Assistants } \\
\hline Office Clerks (Gen) & & 3.0 & 3.0 & 3.0 & 3.0 & 3.0 & 3.0 & 3.0 \\
\hline \multicolumn{9}{|c|}{ office Clerks (Special) } \\
\hline Secretaries & & 5.0 & 5.0 & 5.0 & 5.0 & 5.0 & 5.0 & 5.0 \\
\hline \multicolumn{9}{|l|}{ Typist/Word Process } \\
\hline \multicolumn{9}{|l|}{ other } \\
\hline TECHINICI ANSS & & & & & & & & \\
\hline \multicolumn{9}{|l|}{ Computer Oper/Coder } \\
\hline \multicolumn{9}{|l|}{ Drafters } \\
\hline \multicolumn{9}{|l|}{ Engrs/Tech } \\
\hline \multicolumn{9}{|c|}{ Envir. Sci Technicians } \\
\hline \multicolumn{9}{|l|}{ Heal th Phys. Technic. } \\
\hline \multicolumn{9}{|c|}{ Indus. Saf/Heal th Tech } \\
\hline \multicolumn{9}{|l|}{ Instru/Control Tech } \\
\hline \multicolumn{9}{|l|}{ Lab. Technicians } \\
\hline \multicolumn{9}{|l|}{ Media Technicians } \\
\hline \multicolumn{9}{|l|}{ Survey/Map Tech } \\
\hline \multicolumn{9}{|l|}{ other } \\
\hline \multicolumn{9}{|l|}{ CRAFTS } \\
\hline \multicolumn{9}{|l|}{ Carpenters } \\
\hline \multicolumn{9}{|l|}{ Electricians } \\
\hline \multicolumn{9}{|l|}{ HVAC } \\
\hline \multicolumn{9}{|l|}{ Machinists } \\
\hline \multicolumn{9}{|l|}{ Masons } \\
\hline Millwrights & & & & & & & & \\
\hline
\end{tabular}




\begin{tabular}{|c|c|c|c|c|c|c|c|c|}
\hline \multicolumn{4}{|c|}{ Full-Time Equivalent Staff by Job Description } & \multicolumn{5}{|c|}{ NOTE: Job Family Only After 1996} \\
\hline \multicolumn{9}{|l|}{ JOB FAMILY } \\
\hline Job category & 1994 & 1995 & 1996 & 1997 & 1998 & 1999 & 2000 & 2001 \\
\hline \multicolumn{9}{|l|}{ Painters } \\
\hline \multicolumn{9}{|l|}{ Plumbers/Pipefitters } \\
\hline \multicolumn{9}{|c|}{ Struct/Metal Workers } \\
\hline \multicolumn{9}{|c|}{ Vehic./Mob Equip Mech } \\
\hline \multicolumn{9}{|l|}{ Welders } \\
\hline \multicolumn{9}{|l|}{ Other } \\
\hline \multirow{2}{*}{\multicolumn{9}{|c|}{$\begin{array}{l}\text { OPERATOQRS } \\
\text { Chemical system }\end{array}$}} \\
\hline & & & & & & & & \\
\hline \multicolumn{9}{|l|}{ Drillers } \\
\hline \multicolumn{9}{|l|}{ Lt. Vehicle Drivers } \\
\hline \multicolumn{9}{|c|}{ Material Moving Equip } \\
\hline \multicolumn{9}{|l|}{ Nuclear Plant } \\
\hline \multicolumn{9}{|c|}{ Utilities Waste Proces } \\
\hline \multicolumn{9}{|l|}{ Other } \\
\hline LABOR \& GEN WORKERS & $\because \because$ & $\therefore$ & $\because$ & & & & $\therefore$ & 4 \\
\hline \multicolumn{9}{|l|}{ Firefighters } \\
\hline \multicolumn{9}{|l|}{ Food Service } \\
\hline \multicolumn{9}{|l|}{ Hand/Help Lab Gen } \\
\hline \multicolumn{9}{|l|}{ Hand/Help Lab Spec } \\
\hline \multicolumn{9}{|l|}{ Janitors/Cleaners } \\
\hline \multicolumn{9}{|l|}{ Laundry Workers } \\
\hline \multicolumn{9}{|l|}{ Security Guards } \\
\hline \multicolumn{9}{|l|}{ Other } \\
\hline TOTAL & * 33.4 & 32.0 & 32.0 & 32.0 & 32.0 & 32.0 & 32.0 & 32.0 \\
\hline
\end{tabular}




\section{Westinghouse Hanford Company MILESTONE DESCRIPTION SHEET}

Title:

Personnel Disposition/Transition During U0-3 Closure

Assigned To:

Gerald F. Saskowsky

Program WBS Designator:

6.10.2.8.4

Control Number: FAH-95-020

\begin{tabular}{l}
\hline MILESTONE TYPE: \\
$\square$ DOE-HO \\
Q DOE-RL \\
$\square$ CNTR \\
\\
\end{tabular}

\begin{tabular}{|l|}
\hline \multicolumn{1}{|c|}{ DIVISION: } \\
$\square$ State \\
$\square$ Federal \\
$\square$ DOE \\
$\square$ RCRA \\
$\square$ TPA Number \\
\\
\hline
\end{tabular}

\begin{tabular}{|l|}
\hline \multicolumn{1}{|c|}{ DELIVERABLE: } \\
$\square$ Report \\
$\square$ Letter \\
$\square$ Drawings \\
X Other (specify) \\
Disposition of \\
employees due to \\
U0-3 facility \\
closure.
\end{tabular}

Date:

$08 / 10 / 94$

CIN:

Due Date:

$02 / 01 / 95$

Rev.:

ADDRESS TO:
$\square$ DOE-HO
$\square$ DOE-RL
$\square$ Other (specify)

"lestone description:

Provide guidance and support to Purex/U0-3 management to ensure an orderly closure of the U0-3 facility with respect to the disposition/transition of

facility personnel. This milestone will be completed by 2/01/95 with available personnel resources.

$$
\begin{array}{ll}
\text { Ex } & .2 \\
\mathrm{NX} & .1
\end{array}
$$

Description of what constitutes completion of this milestone:

Final closure of U0-3 facility and all affected personnel have been relocated to other positions/facilities.

\begin{tabular}{|ll|ll|}
\hline $\begin{array}{l}\text { ost Account Manager } \\
\text { H. A. Sieber }\end{array}$ & Date & Program/Project Manager & Date \\
\hline Program Element Manager & Date & DOE Monitor & Date \\
& & S. A. Host jck & \\
\hline
\end{tabular}




\section{Westinghouse Hanford Company \\ MILESTONE DESCRIPTION SHEET}

\begin{tabular}{|c|c|c|c|}
\hline \multicolumn{3}{|c|}{$\begin{array}{l}\text { litle: } \\
\text { Power Operator Training and Qualification Program }\end{array}$} & \begin{tabular}{|r|} 
Date: \\
$08 / 10 / 94$ \\
\end{tabular} \\
\hline \multicolumn{3}{|l|}{$\begin{array}{l}\text { Assigned To: } \\
\text { Gerald F. Saskowsky }\end{array}$} & CIN: \\
\hline \multicolumn{3}{|c|}{ Program WBS Designator: } & $\begin{array}{r}\text { Due Date: } \\
02 / 01 / 95 \\
\end{array}$ \\
\hline \multicolumn{3}{|c|}{ Control Number: FAH-95-021 } & Rev.: \\
\hline $\begin{array}{l}\text { MILESTONE TYPE: } \\
\square \text { DOE-HQ } \\
\text { X DOE-RL } \\
\square \text { CNTR }\end{array}$ & $\begin{array}{l}\quad \text { DIVISION: } \\
\square \text { State } \\
\square \text { Federal } \\
\square \text { DOE } \\
\square \text { RCRA } \\
\square \text { TPA Number }\end{array}$ & $\begin{array}{l}\text { DELIVERABLE: } \\
\square \text { Report } \\
\square \text { Letter } \\
\square \text { Drawings } \\
\mathbb{X} \text { Other (specify) } \\
\text { Negotiations with } \\
\text { Union. }\end{array}$ & $\begin{array}{l}\text { ADDRESS TO: } \\
\square \text { DOE-HQ } \\
\square \text { DOE-RL } \\
\square \text { Other (specify) }\end{array}$ \\
\hline
\end{tabular}

Milestone description:

Conclude the formal bargaining process for a Power Operator Training and Qualification Program with Operating Engineers Local 280 and HAMTC. This milestone will be completed by 02/01/95 using available personnel resources.

Ex $\quad .2$

Description of what constitutes completion of this milestone:

An agreement between the Company and the Union on the effects/impact of the program on the employees and a ratification of the training program by the members of Operating Engineers Loca] 280, Seniority Group. 006.

\begin{tabular}{|ll|ll|}
\hline st Account Manager & Date & $\begin{array}{l}\text { Program/Project Manager } \\
\text { L. A. Sieber }\end{array}$ & Dyers \\
\hline Program Element Manager & Date & $\begin{array}{l}\text { DOE Monitor } \\
\text { S. A. Hostick }\end{array}$ & Date \\
\hline
\end{tabular}




\section{Westinghouse Hanford Company \\ MILESTONE DESCRIPTION SHEET}

\begin{tabular}{|c|c|c|c|c|}
\hline \multicolumn{4}{|c|}{$\begin{array}{l}\text { Title: } \\
\text { Transition Projects Training on Labor Agreement (HAMTC) }\end{array}$} & \begin{tabular}{r|} 
Date: \\
$08 / 10 / 94$ \\
\end{tabular} \\
\hline \multicolumn{4}{|c|}{$\begin{array}{l}\text { Assigned To: } \\
\text { Gerald F. Saskowsky }\end{array}$} & CIN: \\
\hline \multicolumn{4}{|c|}{$\begin{array}{l}\text { Program WBS Designator: } \\
6.10 .2 .8 .4\end{array}$} & $\begin{array}{r}\text { Due Date: } \\
06 / 01 / 95 \\
\end{array}$ \\
\hline \multicolumn{3}{|c|}{ Control Number: FAH-95-022 } & & Rev.: \\
\hline $\begin{array}{l}\text { MILESTONE TYPE: } \\
\square \text { DOE-HQ } \\
\square \text { DOE-RL } \\
\square \text { CNTR }\end{array}$ & $\begin{array}{l}\quad \text { DIVISION: } \\
\square \text { State } \\
\square \text { Federal } \\
\square \text { DOE } \\
\square \text { RCRA } \\
\square \text { TPA Number }\end{array}$ & $\begin{array}{l}\text { DELIVERABLE: } \\
\square \text { Report } \\
\square \text { Letter } \\
\square \text { Drawings } \\
\square \text { Other (specify) }\end{array}$ & $\begin{aligned} & A D \\
& \square D O \\
& \square D O \\
& \square \text { Oth }\end{aligned}$ & $\begin{array}{l}\text { DRESS TO: } \\
\text { E-HQ } \\
\text { E-RL } \\
\text { ler (specify) }\end{array}$ \\
\hline
\end{tabular}

lestone description:

A strategic initiative for Transition Projects is to ensure full utilization and implementation of key flexibility language in the HAMTC labor agreement that enhances the efficiencies of operations. Develop and deliver a training module on key elements, such as the Craft Alignment Program (CAP). This milestone will be completed by 6/01/95 with available personnel resources.

$$
\text { Ex } \quad .2
$$

Description of what constitutes completion of this milestone:

Completion of training for all appropriate personnel within Transition Projects.

\begin{tabular}{|lc|ll|}
\hline -ost Account Manager & Date & Program/Project Manager & Date \\
H. A. Sieber & & L. L. Myers & \\
\hline Program Element Manager & Date & DOE Monitor & Date \\
& & S. A. Hostick & \\
\hline
\end{tabular}




\section{Westinghouse Hanford Company}

\section{MILESTONE DESCRIPTION SHEET}

\begin{tabular}{|c|c|c|c|}
\hline \multicolumn{3}{|c|}{$\begin{array}{l}\text { Title: } \\
\text { Labor/Management Cooperation Program }\end{array}$} & \begin{tabular}{|l|} 
Date: \\
$08 / 10 / 94$ \\
\end{tabular} \\
\hline \multicolumn{3}{|l|}{ Assigned To: } & CIN: \\
\hline \multicolumn{3}{|c|}{$\frac{\text { Ben D. Corder }}{\text { Program WBS Designator: }}$} & $\begin{array}{l}\text { Due Date: } \\
03 / 01 / 94 \\
\end{array}$ \\
\hline \multicolumn{3}{|c|}{ Control Number: FAH-95-023 } & Rev.: \\
\hline $\begin{array}{l}\text { MILESTONE TYPE: } \\
\square \text { DOE-HO } \\
\text { 囚 DOE-RL } \\
\square \text { CNTR }\end{array}$ & $\begin{array}{l}\text { DIVISION: } \\
\square \text { State } \\
\square \text { Federal } \\
\square \text { DOE } \\
\square \text { RCRA } \\
\square \text { TPA Number }\end{array}$ & $\begin{array}{l}\text { DELIVERABLE: } \\
\square \text { Report } \\
\square \text { Letter } \\
\square \text { Drawings } \\
\square \text { Other (specify) }\end{array}$ & $\begin{array}{l}\text { ADDRESS TO: } \\
\square \text { DOE-HO } \\
\square \text { DOE-RL } \\
\square \text { Other (specify) }\end{array}$ \\
\hline
\end{tabular}

-ilestone description:

Restructure the Labor Management Cooperation Program. This milestone will be completed with available personnel.

Ex $\quad .4$

Description of what constitutes completion of this milestone:

Restructuring the membership and committee assignments by March 1, 1995.

\begin{tabular}{|c|c|c|c|}
\hline $\begin{array}{l}\text { Jst Account Manager } \\
\text { H. A. Sieber }\end{array}$ & Date & $\begin{array}{l}\text { Program/Project Manager } \\
\text { L. L. Myers }\end{array}$ & Date \\
\hline Program Element Manager & Date & $\begin{array}{l}\text { DOE Monitor } \\
\text { S. A. Hostick }\end{array}$ & Date \\
\hline
\end{tabular}




\begin{tabular}{|c|c|c|c|}
\hline \multicolumn{3}{|c|}{$\begin{array}{l}\text { Title: } \\
\text { Develop and Implement Human Resources Staff Relations Rotational Program }\end{array}$} & $\begin{array}{r}\text { Date: } \\
08 / 10 / 94 \\
\end{array}$ \\
\hline \multicolumn{3}{|l|}{$\begin{array}{l}\text { Assigned To: } \\
\text { Joan T. Eckert }\end{array}$} & CIN: \\
\hline \multicolumn{3}{|l|}{$\begin{array}{l}\text { Program WBS Designator: } \\
6.10 .2 .8 .5\end{array}$} & \begin{tabular}{|r|} 
Due Date: \\
$09 / 30 / 94$ \\
\end{tabular} \\
\hline \multicolumn{3}{|c|}{ Control Number: FAH-95-024 } & Rev.: \\
\hline $\begin{array}{l}\text { MILESTONE TYPE: } \\
\square \text { DOE-HO } \\
\square \text { DOE-RL } \\
\square \text { CNTR }\end{array}$ & $\begin{array}{l}\text { DIVISION: } \\
\square \text { State } \\
\square \text { Federal } \\
\square \text { DOE } \\
\square \text { RCRA } \\
\square \text { TPA Number }\end{array}$ & $\begin{array}{l}\text { DELIVERABLE: } \\
\square \text { Report } \\
\square \text { Letter } \\
\square \text { Drawings } \\
\square \text { Other (specify) }\end{array}$ & $\begin{array}{l}\text { ADDRESS TO: } \\
\square \text { DOE-HQ } \\
\square \text { DOE-RL } \\
\square \text { Other (specify) }\end{array}$ \\
\hline
\end{tabular}

- ${ }^{\text {illestone description: }}$

Develop and implement a rotational program within Human Resources Staff

Relations to enhance the effectiveness of the organization. This milestone

will be completed by $9 / 30 / 95$ with available personnel resources.

$\begin{array}{ll}\text { Ex } & .3 \\ \mathrm{Nx} & .2\end{array}$

Description of what constitutes completion of this milestone:

The implementation of a rotational program and the successful rotation of at

least three staff members.

\begin{tabular}{|ll|ll|}
\hline :ost Account Manager & Date & $\begin{array}{l}\text { Program/Project Manager } \\
\text { L. L. Myers }\end{array}$ & Date \\
\hline H. A. Sieber & Date & $\begin{array}{l}\text { DOE Monitor } \\
\text { Program Element Manager }\end{array}$ & Date Hostick \\
\end{tabular}




\section{Westinghouse Hanford Company \\ MILESTONE DESCRIPTION SHEET}

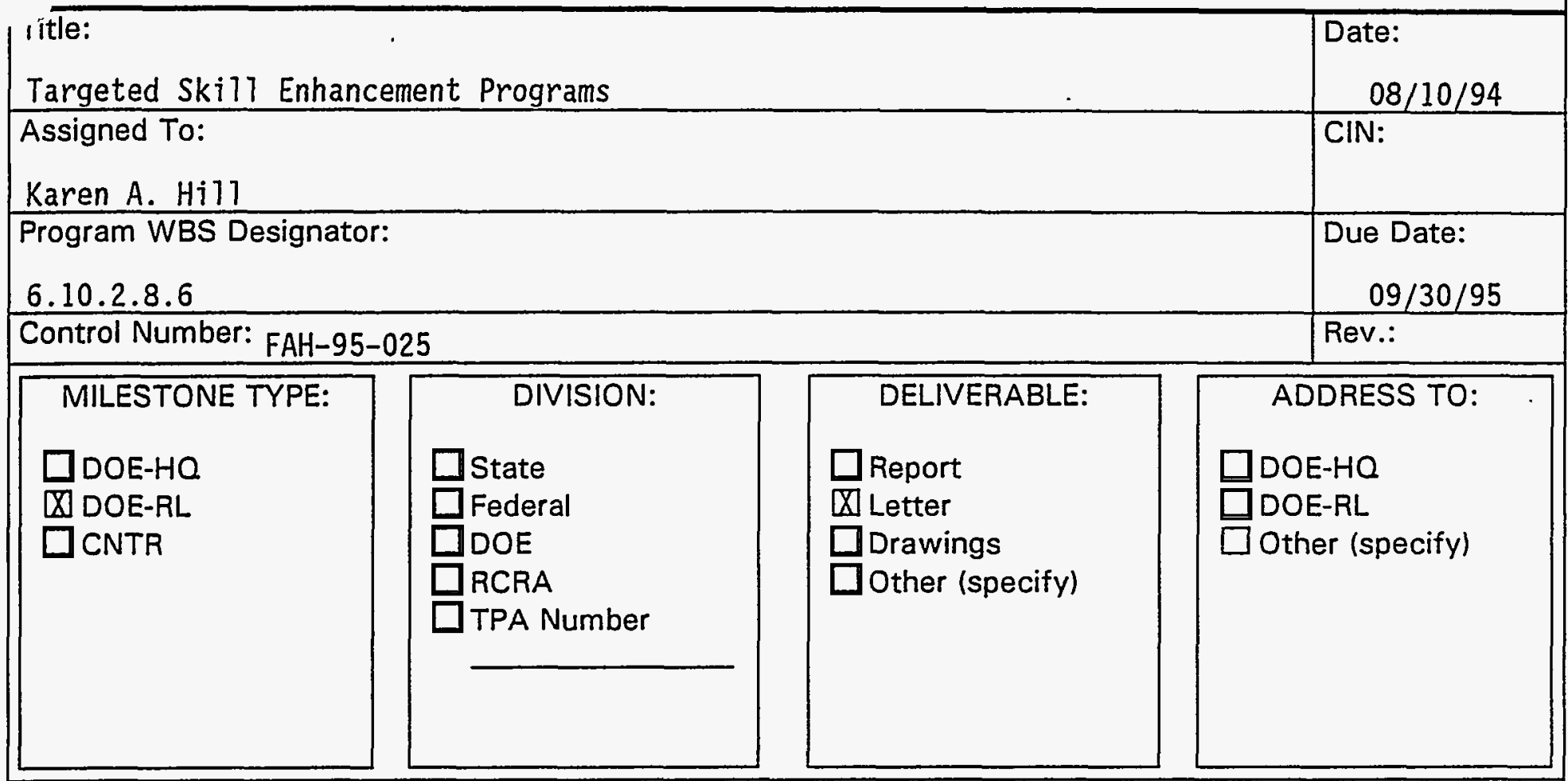

Milestone description:

Conduct six sessions each of Targeted Skill Enhancement Programs: New

Managers' Orientation, Standards of Conduct Administration, Administrative

Professional Company Orientation. Nine sessions will be completed by

$3 / 30 / 95$, and the remaining nine sessions by $9 / 30 / 95$. This milestone will be completed using available personnel resources.

$\begin{array}{ll}\text { Ex } & .3 \\ \mathrm{Nx} & .2\end{array}$

Description of what constitutes completion of this milestone:

A report will verify the existence of completed class rosters for each session conducted. This report wil1 be made on 3/30/95 and 9/30/95.

\begin{tabular}{|c|c|c|c|}
\hline $\begin{array}{l}\text { ost Account Manager } \\
\text { H. A. Sieber }\end{array}$ & Date & $\begin{array}{l}\text { Program/Project Manager } \\
\text { L. L. Myers }\end{array}$ & Date \\
\hline Program Element Manager & Date & $\begin{array}{l}\text { DOE Monitor } \\
\text { S. A. Hostick }\end{array}$ & Date \\
\hline
\end{tabular}




\section{Westinghouse Hanford Company \\ MILESTONE DESCRIPTION SHEET}

\begin{tabular}{|c|c|c|c|}
\hline \multicolumn{3}{|c|}{$\begin{array}{l}\text { Title: } \\
\text { HGU Strategic Bargaining PIan for Wage Reopener }\end{array}$} & \begin{tabular}{|r|} 
Date: \\
$08 / 10 / 94$ \\
\end{tabular} \\
\hline \multicolumn{3}{|c|}{$\begin{array}{l}\text { Assigned To: } \\
\text { Frank A. Bl owe/Ben D. Corder }\end{array}$} & CIN: \\
\hline \multicolumn{3}{|c|}{ Program WBS Designator: } & \begin{tabular}{r|} 
Due Date: \\
$09 / 30 / 95$ \\
\end{tabular} \\
\hline \multicolumn{3}{|c|}{ Control Number: $\mathrm{FAH}-95-026$} & Rev.: \\
\hline $\begin{array}{l}\text { MILESTONE TYPE: } \\
\square \text { DOE-HO } \\
\square \text { DOE-RL } \\
\square \text { CNTR }\end{array}$ & $\begin{array}{l}\text { DIVISION: } \\
\square \text { State } \\
\square \text { Federal } \\
\square \text { DOE } \\
\square \text { RCRA } \\
\square \text { TPA Number }\end{array}$ & $\begin{array}{l}\text { DELIVERABLE: } \\
\square \text { Report } \\
\square \text { Letter } \\
\square \text { Drawings } \\
\square \text { Other (specify) }\end{array}$ & $\begin{array}{l}\text { ADDRESS TO: } \\
\square \text { DOE-HO } \\
\square \text { DOE-RL } \\
\square \text { Other (specify) }\end{array}$ \\
\hline
\end{tabular}

Mailestone description:

- To develop the wage and benefit package for bargaining with the Hanford Guards Union for the 30-day wage reopener period commencing October 1, 1995. This milestone will be completed by $9 / 30 / 95$ with available personnel resources.

$\begin{array}{ll}\text { Ex } & .2 \\ \mathrm{Nx} & .1\end{array}$

Description of what constitutes completion of this milestone:

A written $\mathrm{plan} /$ document delivered to RL Contractor Industrial Relations which contains the economic parameters that Westinghouse Hanford Company would use in negotiations with the Hanford Guards Union.

\begin{tabular}{|c|c|c|c|}
\hline $\begin{array}{l}\text { Jst Account Manager } \\
\text { H. A. Sieber }\end{array}$ & Date & $\begin{array}{l}\text { Program/Project Manager } \\
\text { L. L. Myers }\end{array}$ & Date \\
\hline Program Element Manager & Date & $\begin{array}{l}\text { DOE Monitor } \\
\text { S. A. Hostick }\end{array}$ & Date \\
\hline
\end{tabular}




\section{Westinghouse Hanford Company \\ MILESTONE DESCRIPTION SHEET}

\begin{tabular}{|c|c|c|c|c|}
\hline \multicolumn{4}{|c|}{$\begin{array}{l}\text { Title: } \\
\text { Pre-Negotiations Planning for Alcohol Testing for Commercial Drivers License } \\
\text { Compliance }\end{array}$} & $\begin{array}{r}\text { Date: } \\
08 / 10 / 94\end{array}$ \\
\hline \multicolumn{4}{|c|}{$\begin{array}{l}\text { Assigned To: } \\
\text { Frank A. Blowe/Ben D. Corder }\end{array}$} & CIN: \\
\hline \multicolumn{4}{|c|}{$\begin{array}{l}\text { Program WBS Designator: } \\
6.10 .2 .8 .1\end{array}$} & $\begin{aligned} \text { Due Date: } \\
11 / 01 / 94 \\
\end{aligned}$ \\
\hline \multicolumn{4}{|c|}{ Control Number: FAH-95-027 } & Rev.: \\
\hline $\begin{array}{l}\text { MILESTONE TYPE: } \\
\square \text { DOE-HQ } \\
\square] \text { DOE-RL } \\
\square \text { CNTR }\end{array}$ & $\begin{array}{l}\text { DIVISION: } \\
\square \text { State } \\
\square \text { Federal } \\
\square \text { DOE } \\
\square \text { RCRA } \\
\square \text { TPA Number }\end{array}$ & $\begin{array}{l}\text { DELIVERABLE: } \\
\square \text { Report } \\
\square \text { Letter } \\
\square \text { Drawings } \\
\square \text { Other (specify) }\end{array}$ & \multicolumn{2}{|c|}{$\begin{array}{l}\text { ADDRESS TO: } \\
\square \text { DOE-HQ } \\
\square \text { DOE-RL } \\
\square \text { Other (specify) }\end{array}$} \\
\hline
\end{tabular}

Milestone description:

To develop a plan to bargain the alcohol testing requirements under the provisions of the Commercial Drivers License (CDL) regulations. This

milestone will be completed by $11 / 01 / 94$ with available personnel resources.

Ex $\quad .2$

Description of what constitutes completion of this milestone:

A written document reviewed with WHC Labor Relations and Human Resources

management that outlines the WHC plan to comply with the CDL requirements.

\begin{tabular}{|c|c|c|c|}
\hline $\begin{array}{l}\text { ust Account Manager } \\
\text { H. A. Sieber }\end{array}$ & Date & $\begin{array}{l}\text { Program/Project Manager } \\
\text { L. L. Myers }\end{array}$ & Date \\
\hline Program Element Manager & Date & $\begin{array}{l}\text { DOE Monitor } \\
\text { S. A. Hostick }\end{array}$ & Date \\
\hline
\end{tabular}


플 
Site Support Program Plan Approval Sheet

6.10.2.2 Education Outreach

(Program WBS\#

Name)

Assistant Manager-Contracting Officer's Representative

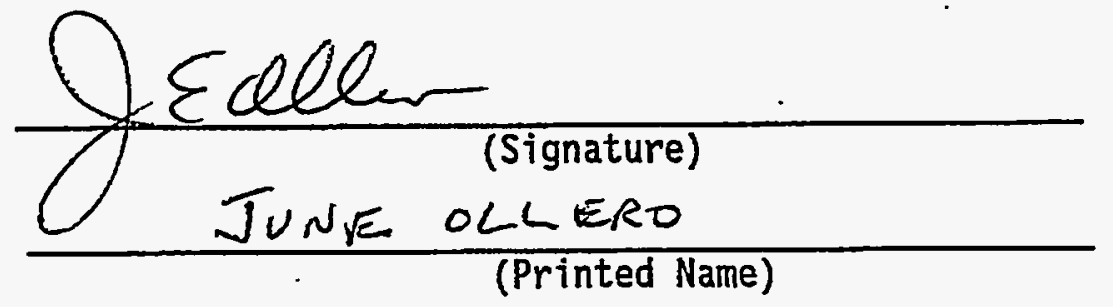

$$
\frac{9 / 19 / 94}{\text { (Date) }}
$$

Program Manager
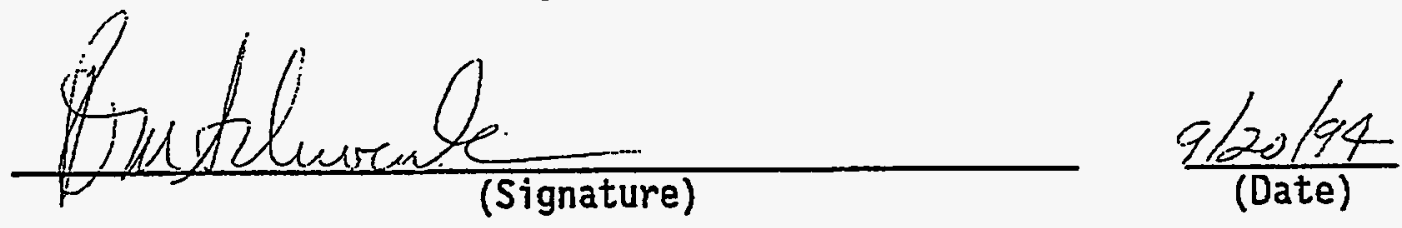

R. M. Schwenk

(Printed Name)

SSPPAPR.OVE 
The Program Overview of the Education Pipeline Program is:

Economic Transition leads the Hanford team in partnering with regional communities to leverage Hanford's substantial assets with related private sector resources to simultaneously accomplish the Hanford cleanup mission and advance the economic diversification of the region. A strategic element of this Hanford community partnership is the shared understanding that a strong regional educational base is tantamount to preparing and maintaining a workforce capable of meeting the needs of today and the challenges of the future. For this reason, Economic Transition is committed to sustaining dynamic business-education-community partnerships that link regional educational resources with the professional preparation capabilities at Hanford to provide educationally and experiential enhanced workforce candidates for Hanford, regional communities, and the environmental sector at 7 arge.

Economic Transition's contribution to these workforce preparation partnerships comes in the form of a workforce delivery system know as the Hanford Intern Pipeline. Included in the pipeline strategy are a spectrum of on-site and off-site activities and experiences that stimulate and enhance participation in math, science, and engineering studies at all educational levels. The pipeline's ultimate goal is to supply an environmental workforce that is more diverse, better educated, and work-place ready. This will be accomplished through innovative involvement in early educational environments, providing degree-compatible internships mutually beneficial to intern and employer, and strategic partnering with key educational, community, multi-cultural, professional, and technical entities. 


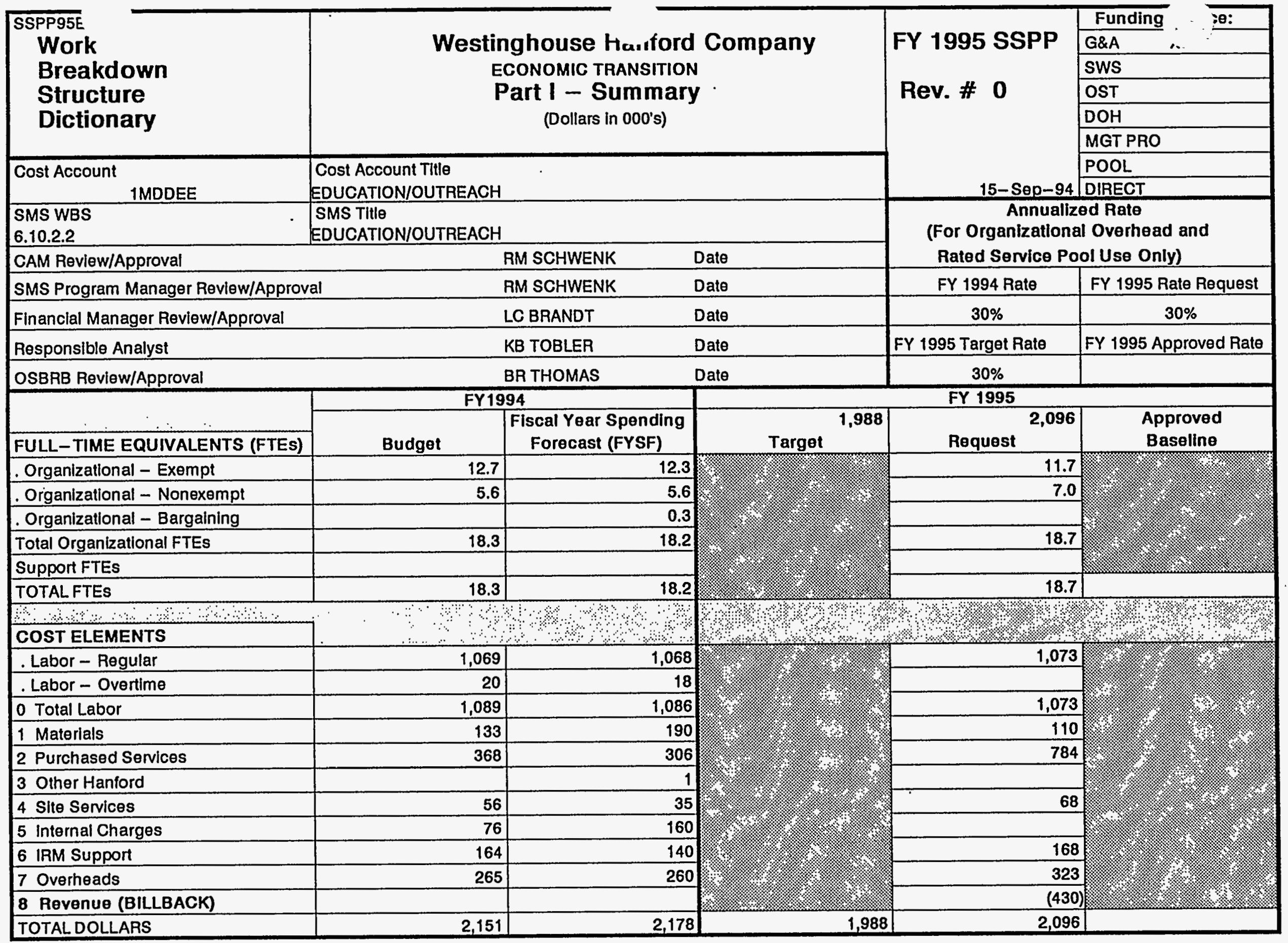


COST ACCOUNT

Work Breakdown

Structure

Dictionary

\section{Westinghouse Hanford Company}

FY 1995 SSPP

Part II - Element Definition

Revision \# 0

\begin{tabular}{|l|l|}
\hline WBS ELEMENT CODE: $\quad 6.10 .2 .2$ & TITLE: $\quad$ EDUCATION/OUTREACH \\
\hline ELEMENT TASK DESCRIPTION &
\end{tabular}

\section{COST CONTENT -}

Labor, P.O. Contracts and other operating costs in support of Education and Outreach.

\section{TECHNICAL CONTENT -}

Support the Hanford-community partnership by assisting in a strong regional educatlonal base by preparing and maintaining a work force capable of meeting the needs of today and the challenges of the future. These goals will be accomplished through innovative involvement in early educational environments, providing degree-compatible internships mutually beneficlal to intern and employer, and strategic partnering with key educational, community, multi-cultural, professional, and technical entities.

\section{OBJECTIVES -}

Sustain dynamic business-education-community partnerships that link regional educatlonal resources with the professional preparation capabilities at Hanford to provide educationally and experiential enhanced work force candidates for Hanford, regional communities, and the environmental sector at large.

Continue the Hanford Intern Pipeline whose ultimate goal is to supply an environmental work force that is more diverse, better educated, and work- place ready.

New scope includes Foreign Visitor and Assignment Program which includes the forelgn national. processing services.

\section{ASSUMPTIONS/CONSTRAINTS -}

Educatlon/Outreach programs are constrained by lack of Company support resources and understanding in the vital role in educating and enhancing the skills of the future work force. Mandated headcount constraints and ilmited funding sources have a direct bearing on the success of the educatlonal programs.

It assumed the proposed billback for student interns will be approved and will be used to offset the total requested funding.

\section{MILESTONES -}

Included under sections 5.0 and 6.0, "Mllestone Log Sheet" and "Milestone Descriptlon Sheets," respectively.

\section{DELIVERABLES -}

Included under sections 5.0 and 6.0, "Milestone Log Sheet" and "Milestone Description Sheets," respectlvely. 


\section{Cost}

\section{WORK STATEMENT -}

\section{REQUESTS WITHIN TARGET:}

Activity Detailed Description

Management and administration includes primarily IRM assessments and general supplles.

\section{Activity Detalled Description}

Labor Cost

Non-Labor Cost

Pre-college outreach development of students in sclence, technical, and math through a systematic approach toward the enhancement of interpersonal, mathematic and scientific skills.

\section{Activity Detalled Description}

Manage the Hanford student intern pipeline program at Hanford; Coordinate the PETE-Northwest partnership; and solidify other support partnerships in eduational and community organizations.

Activity Detailed Descriptlon

Develop innovative environmental eduation concepts locally, nationally, and internationally; serve as DOE's education consortia for Historically Black Colleges and Universilies/Minority Education Institutes.

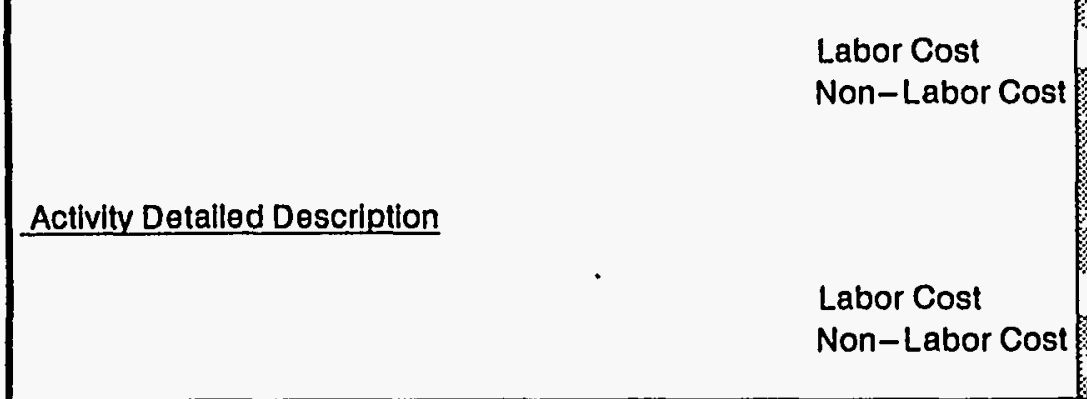

Labor Cost

Non-Labor Cost

Non-Labor Cost

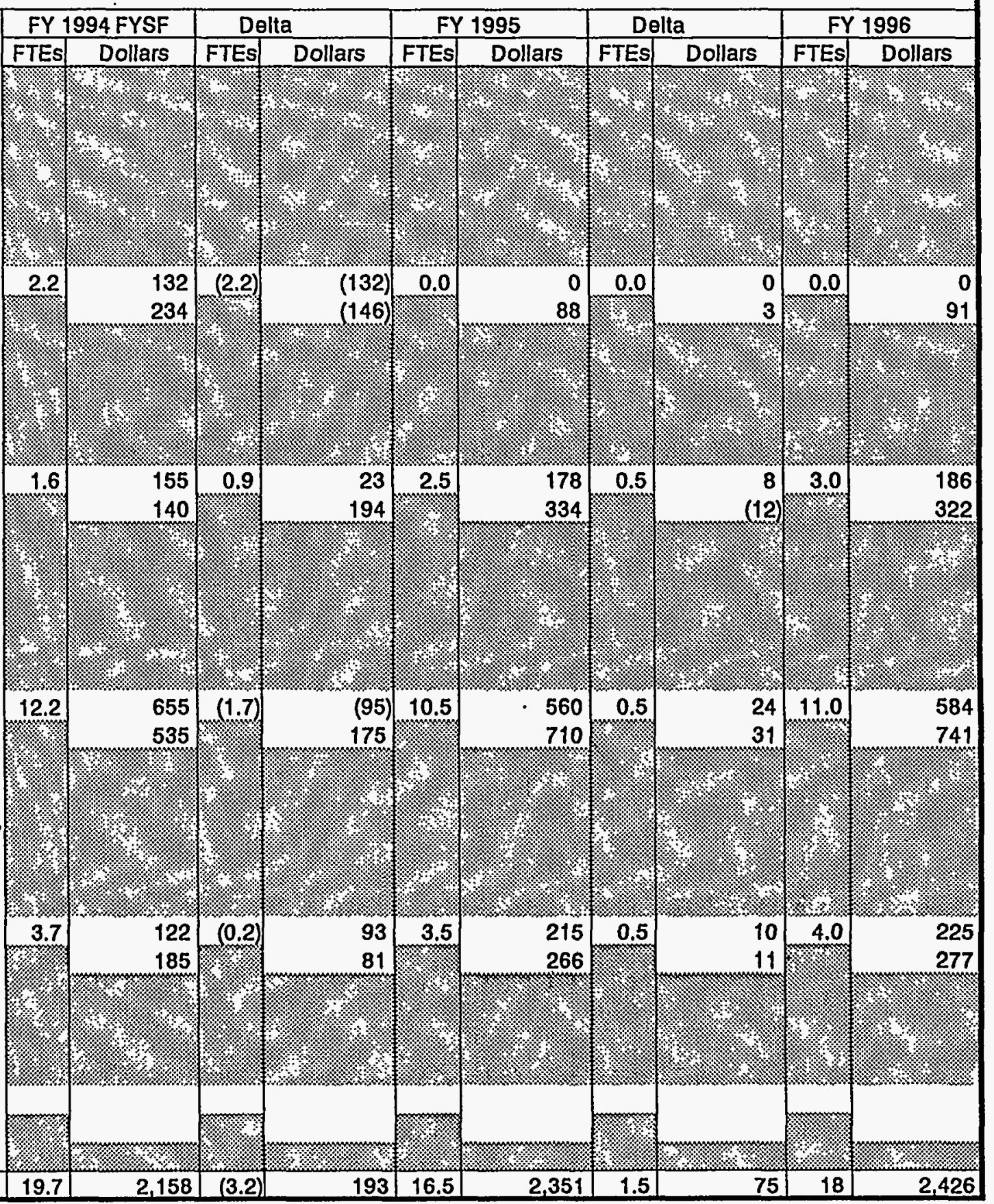




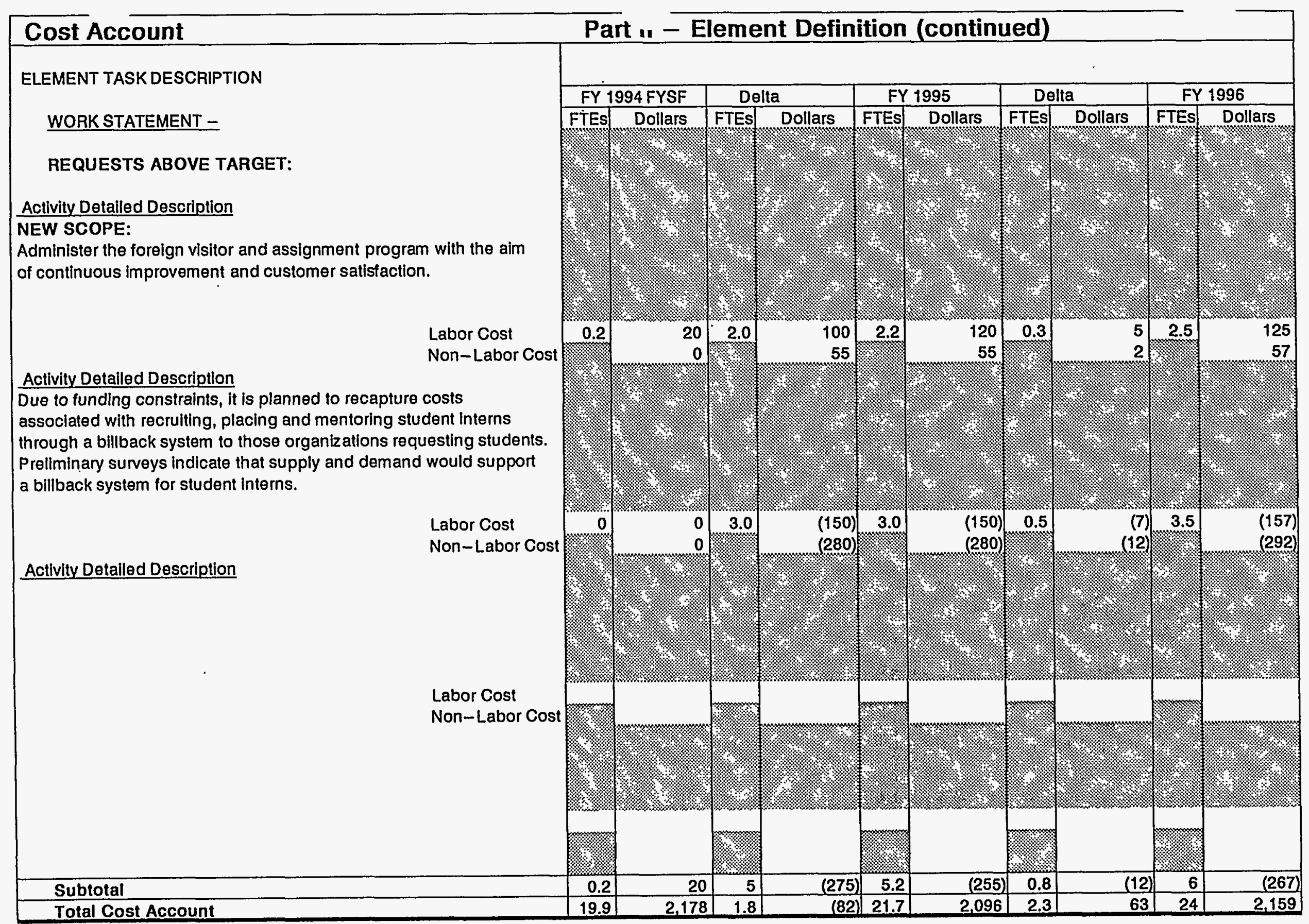




\begin{tabular}{|c|c|c|}
\hline $\begin{array}{c}\text { Mission/Vision } \\
\text { University/College Affairs }\end{array}$ & $\begin{array}{c}\text { Westinghouse Hanford Company } \\
\text { EDUCATION PIPELINE } \\
\text { SMS/WBS No. 6.10.2.2 }\end{array}$ & $\begin{array}{c}\text { Site Support Program P1an } \\
\text { Date Prepared: August 31, 1994 }\end{array}$ \\
\hline
\end{tabular}

The Mission for the University/College Affairs Program is:

Partnering academia, business, and communities through career-related internship activities to supply an environmental workforce capable of doing the job now and solving tomorrow's environmental challenges.

The Mission for the University/College Affairs Program is:

We will be an international leader in preparing tomorrow's environmental workforce through strategic academic-industry internships.

Program's Tie-In to RL's Program

University and College Affairs business strategy closely parallels the strategy in the RL Educational Workforce Pipeline Strategic $P 1$ an dated $X X / X X / X X$. UCA's Environmental Intern Center manages Hanford's Student Intern Pipeline and is considered the model for pipeline processes and services throughout the DOE complex. UCA's Partnership Development activities clearly support RL's mission focusing on partnering with educational and community entities and leveraging those resources to increase support for and multi-cultural participation in Hanford's Student Intern Pipeline efforts. UCA's newest addition, the Foreign Visitor and Assignment Program, truly adds "international" capability and to the UCA team with their foreign national processing services. 


\begin{tabular}{|c|c|c|}
\hline $\begin{array}{l}\text { Program Objectives } \\
\text { University/College Affairs }\end{array}$ & $\begin{array}{c}\text { Westinghouse Hanford Company } \\
\text { EDUCATION PIPELINE } \\
\text { SMS/WBS No. } 6.10 .2 .2\end{array}$ & $\begin{array}{l}\text { FY } 1995 \\
\text { Site Support Program P1 an } \\
\text { Date Prepared: August 31, } 1994\end{array}$ \\
\hline
\end{tabular}

\section{The Program Objectives for the University/College Affairs Program are:}

1) To be a leading innovator, improvement catalyst, and the supplier of choice for Student Intern Pipeline processes and services and environmental workforce professionals.

2) To be the benchmark for education-industry-community partnering and multi-cultural student participation strategies.

3) To be the change agents responsible for significant process and customer satisfaction improvements to the DOE complex-wide Foreign Visitor and Assignment Program.

4) To be an early prime candidate for business "spin-off" to the private sector. 


\begin{tabular}{|c|c|c|}
\hline $\begin{array}{c}\text { Program Strategies } \\
\text { University/College Affairs }\end{array}$ & $\begin{array}{c}\text { Westinghouse Hanford Company } \\
\text { EDUCATION PIPELINE } \\
\text { SMS/WBS No. 6.10.2.2 }\end{array}$ & $\begin{array}{c}\text { FY 1995 } \\
\text { Site Support Program P7an } \\
\text { Date Prepared: August 31, 1994 }\end{array}$ \\
\hline
\end{tabular}

The Program Mission Strategy for the University/College Affairs Program is to continue to:

1) Manage the Environmental Intern Center (EIC), expanding its scope to include a variety of services to al1 Hanford contractors and RL as well as piloting the supply of internship services to other DOE site contractors and local community (private sector) customers.

2) Coordinate the establishment of PETE-Northwest and solidify a variety of support partnerships with strategic multi-cultural, professional, technical, educational, and community organizations.

3) Administer the Foreign Visitor and Assignment Program with the aim of continuous process improvement and customer satisfaction. 
The Assumptions and Constraints for the University/College Affairs Program are:

1) A11 plans, funding (G\&A and other sources), and head count are approved, delivered, and liquid.

2) Work scope does not exceed that identified in the University and College Affairs Strategic Plan to be issued by $11 / 30 / 94$. 


\begin{tabular}{|c|c|c|}
\hline $\begin{array}{l}\text { Mission/Vision } \\
\text { Special Programs }\end{array}$ & $\begin{array}{c}\text { Westinghouse Hanford Company } \\
\text { EDUCATION PIPELINE } \\
\text { SMS/WBS No. } 6.10 .2 .2\end{array}$ & $\begin{array}{c}\text { FY } 1995 \\
\text { Site Support Program P1an } \\
\text { Date Prepared: August 31, } 1994\end{array}$ \\
\hline
\end{tabular}

The Mission of Special Programs is to:

Develop and implement innovative environmental education concepts locally, nationally, and international1y. Serve as Westinghouse Hanford Company's point-of-contact and coordinator of Department of Energy's education consortia and Historically Black Colleges and Universities/Minority Education Institutes.

The Vision of Special Programs is to:

Administer Westinghouse Hanford Company's and Economic Transition's participation in developing environmental education programs and projects with the expectation of significantly improving science literacy in the United States by year 2000. 


\begin{tabular}{|c|c|c|}
\hline $\begin{array}{c}\text { Program Objectives } \\
\text { Special Programs }\end{array}$ & $\begin{array}{c}\text { Westinghouse Hanford Company } \\
\text { EDUCATION PIPELINE } \\
\text { SMS/WBS No.6.10.2.2 }\end{array}$ & $\begin{array}{c}\text { FY 1995 } \\
\text { Site Support Program PTan } \\
\text { Date Prepared: August 31, 1994 }\end{array}$ \\
\hline
\end{tabular}

The Program Objectives of Special Programs:

1) To acquire through grants and funding applications, resources to support environmental education programs and projects of the Office of Special Programs.

2) Manage such funds to significantly improve science literacy in the United States and offer environmental science education opportunities internationaliy. 


\begin{tabular}{|l|c|c|}
\hline & Westinghouse Hanford Company & $\begin{array}{c}\text { FY 1995 } \\
\text { Site Support Program P7an } \\
\text { Program Strategy } \\
\text { Special Programs }\end{array}$ \\
EDUCATION PIPELINE & SMS/WBS No. 6.10.2.2 & Date Prepared: August 31, 1994 \\
\hline
\end{tabular}

The Program Mission Strategy of Special Programs:

1) Acquire baseline funding from the Department of Energy.

2) Leverage baseline funds with funds from other federal agencies.

3) Acquire funds from foundations and other sources for program sustainability. 


\begin{tabular}{|c|c|c|}
\hline $\begin{array}{c}\text { Assumptions and Constraints } \\
\text { Special Programs }\end{array}$ & $\begin{array}{c}\text { West inghouse Hanford Company } \\
\text { EDUCATION PIPELINE } \\
\text { SMS/WBS No. } 6.10 .2 .2\end{array}$ & $\begin{array}{l}\text { FY } 1995 \\
\text { Site Support Program Plan } \\
\text { Date Prepared: 31, } 1994 \\
\end{array}$ \\
\hline
\end{tabular}

The Assumptions and Constraints of Special Programs:

1) It is assumed that environmental education and support of Historically B1ack Colleges and Universities/Minority Education Institutions will remain a priority of the current United States Government's Administration.

2) A major constraint to achieving mission and vision is the lack of human resources that is resulting from current "head count" mandate. 


\begin{tabular}{|c|c|c|}
\hline $\begin{array}{c}\text { Vision/Mission } \\
\text { Pre-College Outreach Career } \\
\text { Development }\end{array}$ & $\begin{array}{c}\text { Westinghouse Hanford Company } \\
\text { Education Pipeline } \\
\text { SMS/WBS No. 6.10.2.2 }\end{array}$ & $\begin{array}{c}\text { FY } 1995 \\
\text { Site Support Program PIan } \\
\text { Date Prepared: August 31, 1994 }\end{array}$ \\
\hline
\end{tabular}

VISION: $\quad$ Pre-college Outreach Development's Science, Technical, Enrichment Programs (STEP) wil1 guide students through a systematic approach toward the enhancement of their interpersonal, mathematic, and scientific skilis. STEP has its foundation grounded in the vision that the enriched development of interpersonal, mathematic, and scientific skills will pave the way for Pre-ColTege Outreach Development to engage every mind . . . harness every volt of passionate energy. . bring excitement to the lives of students... and break every artificial barrier between them. The intended result: A potential source of diverse, highly efficient employees to support our Environmental Management Mission.

MISSION: Pre-College Outreach Development serves as the catalyst in coordinating, developing, and implementing partnerships and programs with all segments of the educational community and stakeholders to successfully complete WHC and Richland Operations Environmental Management (EM) mission.

The partnerships and programs will provide encouragement, work experience opportunities, and informational access designed to enhance the abilities of students interested in entering career paths related to the EM mission. 


\begin{tabular}{|c|c|c|}
\hline $\begin{array}{c}\text { Program Objectives } \\
\text { Pre-College Outreach Career } \\
\text { Development }\end{array}$ & $\begin{array}{c}\text { Hestinghouse Hanford Company } \\
\text { Education Pipeline } \\
\text { SMS/WBS No.6.10.2.2 }\end{array}$ & $\begin{array}{c}\text { FY 1995 } \\
\text { Site Support Program P1an } \\
\text { Date Prepared: August 31, 1994 }\end{array}$ \\
\hline
\end{tabular}

\section{PROGRAM OBJECTIVES:}

1.) Prepare K-12 students for tomorrow's workforce. Eventually the students will enter the Hanford Pipeline or assist the community's economic transition as productive citizens.

2.) Provide educators with a clear understanding of skills required in the work environment form a business standpoint.

3.) Provide inspiration and opportunity for the under-privileged and under-utilized segments of the population.

4.) Estab1ish partnerships with schools, educational organizations, and community based businesses.

5.) Involve parents in the educational process of students.

6.) Establish trust between community and Hanford.

7.) Improve the quality and value of students' educational experience. 


\begin{tabular}{|c|c|c|}
\hline $\begin{array}{c}\text { Program Strategies } \\
\text { Pre-College Outreach Career } \\
\text { Development }\end{array}$ & $\begin{array}{c}\text { Hestinghouse Hanford Company } \\
\text { Education Pipeline } \\
\text { SMS/WBS No. 6.10.2.2 }\end{array}$ & $\begin{array}{c}\text { FY 1995 } \\
\text { Site Support Program P1an } \\
\text { Date Prepared: August 31, 1994 }\end{array}$ \\
\hline
\end{tabular}

The goals and objectives are accomplished by the implementation of the following programs.

COMMUNITY AMBASSADOR PROGRAM

Volunteer Ambassadors are dedicated to encouraging, providing support, and acting as role models to students.

\section{SHADOW EXCHANGE PROGRAM}

Educators and industrial professionals exchanging and experiencing each others challenges.

\section{MATHBUILDERS}

Mathbuilders is a problem solving based two-week summer program designed to prepare students for high school algebra.

\section{BIOBUILDERS}

Biobuilders is an environmentally based two-week summer program designed to prepare students for their first high schoot course in Biology.

\section{CHEMBUILDERS}

Chembuilders is a lab based two-week summer program designed to prepare students for their first high school course in Chemistry.

\section{ACT-S0}

Afro-Academic, Cultural, Technological and Scientific 01ympics (ACT-SO) inspires black youth to excel in academic and cultural pursuits. 


\begin{tabular}{|c|c|c|}
\hline $\begin{array}{c}\text { Program Strategies } \\
\text { Pre-College Outreach Career } \\
\text { Development }\end{array}$ & $\begin{array}{c}\text { Westinghouse Hanford Company } \\
\text { Education Pipeline } \\
\text { SMS/WBS No. 6.10.2.2 }\end{array}$ & $\begin{array}{c}\text { FY 1995 } \\
\text { Site Support Program Plan } \\
\text { Date Prepared: August 31,1994 }\end{array}$ \\
\hline
\end{tabular}

\section{DISCOVER "E" PROGRAM}

Assists teachers in better understanding and explaining the world of engineering to their students.

\section{TEACHER ENRICHMENT}

Bridges the gap between the workforce and classroom by helping teachers develop curriculum relevant to the actual work place.

\section{HANFORD EDUCATION CONSORTIUM}

Hanford contractors and the Mid-Columbia regional education community sharing information and resources to improve the efficiency and effectiveness of education outreach programs.

The goals and objectives are accomplished by the implementation of the following programs. 


\begin{tabular}{|c|c|c|}
\hline $\begin{array}{c}\text { Assumptions } \\
\text { Pre-Colege Outreach Career } \\
\text { Development }\end{array}$ & $\begin{array}{c}\text { Westinghouse Hanford Company } \\
\text { Education Pipel ine } \\
\text { SMS/WBS No. 6.10.2.2 }\end{array}$ & $\begin{array}{c}\text { FY 1995 } \\
\text { Site Support Program P7an } \\
\text { Date Prepared: August .31,1994 }\end{array}$ \\
\hline
\end{tabular}

1.) RL will retain an interest in influencing education policy and responsibility for providing funding and resources.

2.) RL, Hanford contractors, and the Environmental Restoration Contractor (ERMC) will retain an active interest in education programs.

3.) The current education system and human resources organizations will not provide the demographicaliy and culturaliy diverse qualified workers to meet the future needs of the Hanford Site.

4.) Students who are exposed to the Pipeline, but who choose not to pursue technical careers, will be encouraged to acquire the science and math ski17s literacy required for administrative and support roles within the EM workforce. 


\begin{tabular}{|c|c|c|}
\hline $\begin{array}{c}\text { Issues and Constraints } \\
\text { Pre-College Outreach Career } \\
\text { Development }\end{array}$ & $\begin{array}{c}\text { Hestinghouse Hanford Company } \\
\text { Education Pipeline } \\
\text { SMS/WBS No.6.10.2.2 }\end{array}$ & $\begin{array}{c}\text { FY } 1995 \\
\text { Site Support Program Plan } \\
\text { Date Prepared: August 31,1994 }\end{array}$ \\
\hline
\end{tabular}

1.) There is a lack of Company support, resources, and understanding of PCOD's vital role in educating and enhancing the skills of the future workforce.

2.) There is an inadequate number of diverse students entering the workforce with the proper skills needed for us to accomplish our EM mission.

3.) PCOD lacks the power and influence to coordinate the efficient use of internal and externat stakeholders' resources to accomplish the common goal of a diverse EM workforce.

4.) Current WHC practices do not create an atmosphere conducive to attract and retain a demographical1y and culturally diverse student for a career within the EM workforce.

5.) The lack of understanding and utilization of cultural differences within WHC's workforce contributes to the problem of productivity.

6.) Public distrust and resistance in helping WHC accomplish its EM mission. 


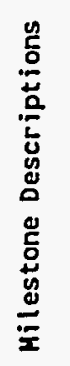

$3_{1}^{3}$ 
ECONOMIC TRANSITION PROGRAM

1995 SITE SUPPORT PROGRAM PLAN

EDUCATION PIPELINE

MILESTONE CONTROL LOG

\begin{tabular}{|c|c|c|c|c|c|c|c|}
\hline \multicolumn{2}{|c|}{ Milestone } & \multirow[b]{2}{*}{$\begin{array}{c}\text { WBS/ } \\
\text { ADS } \\
\end{array}$} & \multirow[b]{2}{*}{ Milestone Description } & \multirow{2}{*}{$\begin{array}{l}\text { Original } \\
\text { Baseline } \\
\text { Completion } \\
\text { Date } \\
\end{array}$} & \multirow{2}{*}{$\begin{array}{l}\text { Revision } \\
\text { Number } \\
\text { Date } \\
\end{array}$} & \multirow{2}{*}{$\begin{array}{c}\text { CIN } \\
\text { Change } \\
\text { Authority } \\
\end{array}$} & \multirow{2}{*}{$\begin{array}{c}\text { Actual } \\
\text { Completion } \\
\text { Date } \\
\end{array}$} \\
\hline Number & Type & & & & & & \\
\hline ET-95-501 & WHC-Key & & Community Informational Meeting & $11 / 04 / 95$ & & & \\
\hline ET- $95-502$ & WHC-Key & & ACT-SO Kickoff Meeting & $12 / 5 / 95$ & & & \\
\hline ET-95-503 & WHC-Key & & Orientation of Judges and Students & $12 / 12 / 95$ & & & \\
\hline ET-95-504 & WHC-Key & & Local ACT-SO Competition & $5 / 4 / 95$ & & & \\
\hline ET-95-505 & WHC-Key & & Locat ACT-SO Banquet & $5 / 13 / 95$ & & & \\
\hline ET-95-506 & WHC-Key & & National ACT-SO Competition & $7 / 7 / 95$ & & & \\
\hline ET-95-601 & WHC-Key & & $\begin{array}{l}\text { Pilot International Co-op Student Exchange } \\
\text { Program }\end{array}$ & $7 / 30 / 95$ & & & . \\
\hline ET-95-602 & WHC-Key & & $\begin{array}{l}\text { Establish MOUs with Multi-Cultural } \\
\text { Technical and Educational Entities }\end{array}$ & $9 / 30 / 95$ & & & \\
\hline ET-95-603 & HHC-Key & & $\begin{array}{l}\text { Issue University and College Affairs } \\
\text { Strategic Plan }\end{array}$ & $11 / 30 / 95$ & & & \\
\hline ET $-95-604$ & WHC-Key & & $\begin{array}{l}\text { Pilot Establishing Non-WHC/BCSR/ICF KH } \\
\text { Customers for Environmental Intern Center } \\
\text { Processes and Services }\end{array}$ & $9 / 30 / 95$ & & & \\
\hline ET-95-605 & HHC-Key & & $\begin{array}{l}\text { Streamline Processes Associated with the } \\
\text { Foreign Visitor and Assignment Program }\end{array}$ & $9 / 30 / 95$ & & & \\
\hline ET-95-701 & WHC-KeY & & $\begin{array}{l}\text { Grant and Funding Research, and Application } \\
\text { Submittal for projects of the Office of } \\
\text { Special Programs }\end{array}$ & $9 / 30 / 95$ & & & \\
\hline
\end{tabular}




\begin{tabular}{|c|c|c|c|}
\hline itle: & nternational $\mathrm{CO}-\mathrm{OP}$ & Student Exchange & Date: $8 / 31 / 94$ \\
\hline \multicolumn{3}{|c|}{ Assigned To: University and College Affairs } & CIN: \\
\hline \multicolumn{3}{|c|}{ Program WBS Designator: } & $\begin{array}{l}\text { Due Date: } \\
7 / 30 / 95\end{array}$ \\
\hline \multicolumn{3}{|c|}{ Control Number: ET-95-601 } & $\begin{array}{l}\text { Revision: } \\
\text { Original }\end{array}$ \\
\hline $\begin{array}{l}\text { MILESTONE TYPE: } \\
\square \text { DOE-HQ } \\
\square \text { DOE-RL } \\
\square \text { CNTR } \\
\text { X WHC KeY }\end{array}$ & $\begin{array}{ll} & \text { DIVISION: } \\
\square & \text { State } \\
\square & \text { Federal } \\
\square & \text { DOE } \\
\square & \text { RCRA } \\
\square & \\
\text { TPA\# }\end{array}$ & $\begin{array}{ll} & \text { DELIVERABLE: } \\
\mathrm{X} & \text { Report } \\
\square & \text { Letter } \\
\square & \text { Drawings } \\
\square \text { Other } \\
\text { (specify) }\end{array}$ & $\begin{array}{l}\text { ADDRESS TO: } \\
\square \text { DOE-HQ } \\
\square \text { DOE-RL } \\
\text { X Other } \\
\text { (specify) } \\
\text { WHC Economic } \\
\text { Transition } \\
\text { Center }\end{array}$ \\
\hline \multicolumn{4}{|c|}{ Milestone Description } \\
\hline \multicolumn{4}{|c|}{$\begin{array}{l}\text { pilot International CO-OP Student Exchange Program will be conducted in } \\
\text { artnership with British Nuclear Fuels (BNFI) } \text { Preliminary discussions } \\
\text { call for } 2 \text { students and I teacher from the Tri-Cities to travel to a BNFL } \\
\text { site in Great Britain in July '95 for a CO-OP work experience, while } 2 \\
\text { students and one teacher from Great Britain will travel to Hanford for a } \\
\text { CO-OP work experience. UCA's Environmental Intern Center (EIC) will act } \\
\text { as liaison with BNFI in formalizing the CO-OP student exchange process, } \\
\text { provide routine CO-OP student support services at the Hanford end, will } \\
\text { identify Tri-City students and teacher for exchange with BNFL. }\end{array}$} \\
\hline \multicolumn{4}{|c|}{ Description of what constitutes completion of this milestone: } \\
\hline \multicolumn{4}{|c|}{$\begin{array}{l}\text { Successful completion will be measured through: 1) Student/Teacher and } \\
\text { Manager/Mentor Satisfaction Surveys; 2) Acceptable student/Teacher } \\
\text { Performance Evaluations; and } 3 \text { ) Successful completion of all learning } \\
\text { objectives specified on pre-exchange Learning Contracts. }\end{array}$} \\
\hline \multicolumn{2}{|c|}{$\begin{array}{l}\text { Cost Account Manager } \\
\text { R. M. Schwenk }\end{array}$} & \multicolumn{2}{|c|}{$\begin{array}{l}\text { Program/Project Manager } \\
\text { Date } \\
\text { R. M. Schwenk }\end{array}$} \\
\hline \multicolumn{2}{|c|}{$\begin{array}{l}\text { Program Element Manager } \\
\text { C. A. Marrero }\end{array}$} & \multicolumn{2}{|l|}{$\begin{array}{l}\text { DOE Monitor } \\
\text { Date } \\
\text { J.E. Ollero }\end{array}$} \\
\hline
\end{tabular}


litle: Establish MOUs With Multi-Cultural Technical Date: 8/31/94 and Educational Entities

\begin{tabular}{ll|l}
\hline Assigned To: University and College Affairs & CIN
\end{tabular}

Program WBS Designator:

Due Date: $9 / 30 / 95$

Control Number: ET-95-602

Revision: Original

MILESTONE TYPE:

D DOE-HQ

DOE-RL

CNTR

$\mathrm{X}$ WHC Key

\begin{tabular}{|ll} 
& DIVISION : \\
$\square$ & State \\
$\square$ & Federal \\
$\square$ & DOE \\
$\square$ & RCRA \\
$\square$ & \\
TPA\#
\end{tabular}

DELIVERABLE:
$\square$ Report
$\square$. Letter
$\square$ Drawings
$\mathrm{X}$ Other
(specify)

Signed Memorandum of Understanding
ADDRESS TO:

D DOE-HQ

口 DOE-RI

$X$ Other

(specify)

WHC Economic Transition

Center

\section{Milestone Description}

o further enhance external support for multi-cultural participation in anford's student Intern Pipeline, UCA's Environmental Intern Center will initiate, negotiate, and implement a new Memorandum of Understanding between WHC and three technical or educational entities representing groups typically under-represented in science or engineering. The purpose of these memoranda will be to leverage resources and support from these organizations to augment motivation, recruitment, socialization, and placement strategies for multi-cultural pipeline participants.

Description of what constitutes completion of this milestone:

Having signed Memoranda of Understanding establishing active partnerships between WHC and three new multi-cultural technical or educational entities that increase external (non-DOE) resources and support for and multi-cultural participation in Hanford's Student Intern pipeline.

Cost Account Manager

R. M. Schwenk

Program Element Manager

C. A. Marrero
Date Program/Project Manager

Date

R. M. Schwenk

Date DOE Monitor

Date

J. E. Ollero 


\begin{tabular}{|c|c|c|}
\hline \multicolumn{2}{|c|}{$\begin{array}{l}\text { Issue University and College Affairs } \\
\text { Strategic Plan }\end{array}$} & Date: $8 / 31 / 94$ \\
\hline \multicolumn{2}{|c|}{ Assigned To: University and College Affairs } & CIN: \\
\hline \multicolumn{2}{|l|}{ Program WBS Designator: } & $\begin{array}{l}\text { Due Date: } \\
11 / 30 / 95\end{array}$ \\
\hline \multicolumn{2}{|l|}{ Control Number: ET-95-603 } & $\begin{array}{l}\text { Revision: } \\
\text { Original }\end{array}$ \\
\hline 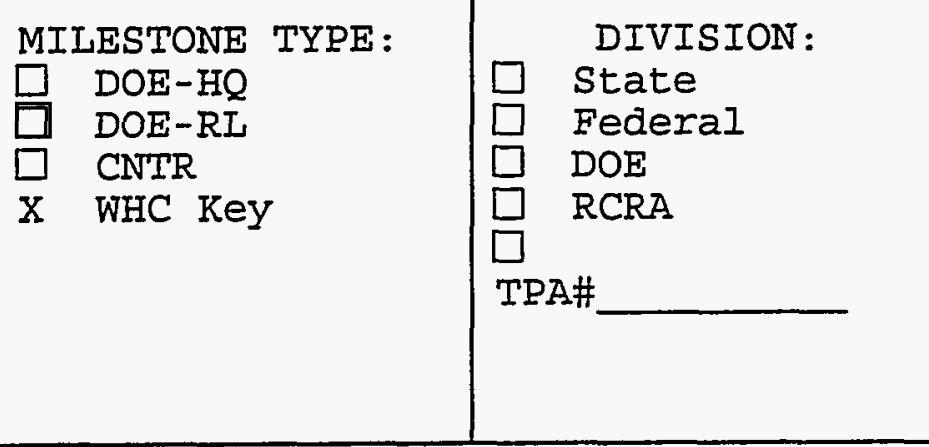 & $\begin{array}{ll} & \text { DELIVERABLE: } \\
& \text { Report } \\
\square & \text { Letter } \\
\square & \text { Drawings } \\
X \text { Other } \\
\text { (specify) } \\
\\
\text { Approved } \\
\text { Strategic Plan } \\
\text { Document }\end{array}$ & $\begin{array}{l}\quad \text { ADDRESS TO: } \\
\square \text { DOE-HQ } \\
\square \text { DOE-RI } \\
\mathrm{X} \text { Other } \\
\text { (specify) } \\
\text { WHC Economic } \\
\text { Transition } \\
\text { Center }\end{array}$ \\
\hline \multicolumn{3}{|l|}{ Milestone Description } \\
\hline \multicolumn{3}{|c|}{$\begin{array}{l}\text { I recent reorganization has combined three previous organizations' } \\
\text { cesources and scope into a new organization known as University and } \\
\text { College Affairs. As a result, a new Strategic Plan needs to be issued } \\
\text { combining the missions of the former Environmental Intern Center, } \\
\text { University and college Curriculum Programs, and Foreign Visitor and } \\
\text { Assignment Programs organizations to establish a consolidated mission, } \\
\text { key business areas, and future initiatives. }\end{array}$} \\
\hline \multicolumn{3}{|c|}{ Description of what constitutes completion of this milestone: } \\
\hline \multicolumn{3}{|c|}{$\begin{array}{l}\text { Issuance of an approved Strategic Plan for University and College Affai } \\
\text { will complete this milestone. }\end{array}$} \\
\hline $\begin{array}{ll}\text { Cost Account Manager } & \text { Date } \\
\text { R. M. Schwenk } & \end{array}$ & \multicolumn{2}{|c|}{$\begin{array}{l}\text { Program/Project Manager } \\
\text { Date } \\
\text { R. M. Schwenk }\end{array}$} \\
\hline $\begin{array}{l}\text { Program Element Manager } \\
\text { C. A. Marrero }\end{array}$ & \multicolumn{2}{|l|}{$\begin{array}{l}\text { DOE Monitor } \\
\text { Date } \\
\text { J. E. Ollero }\end{array}$} \\
\hline
\end{tabular}




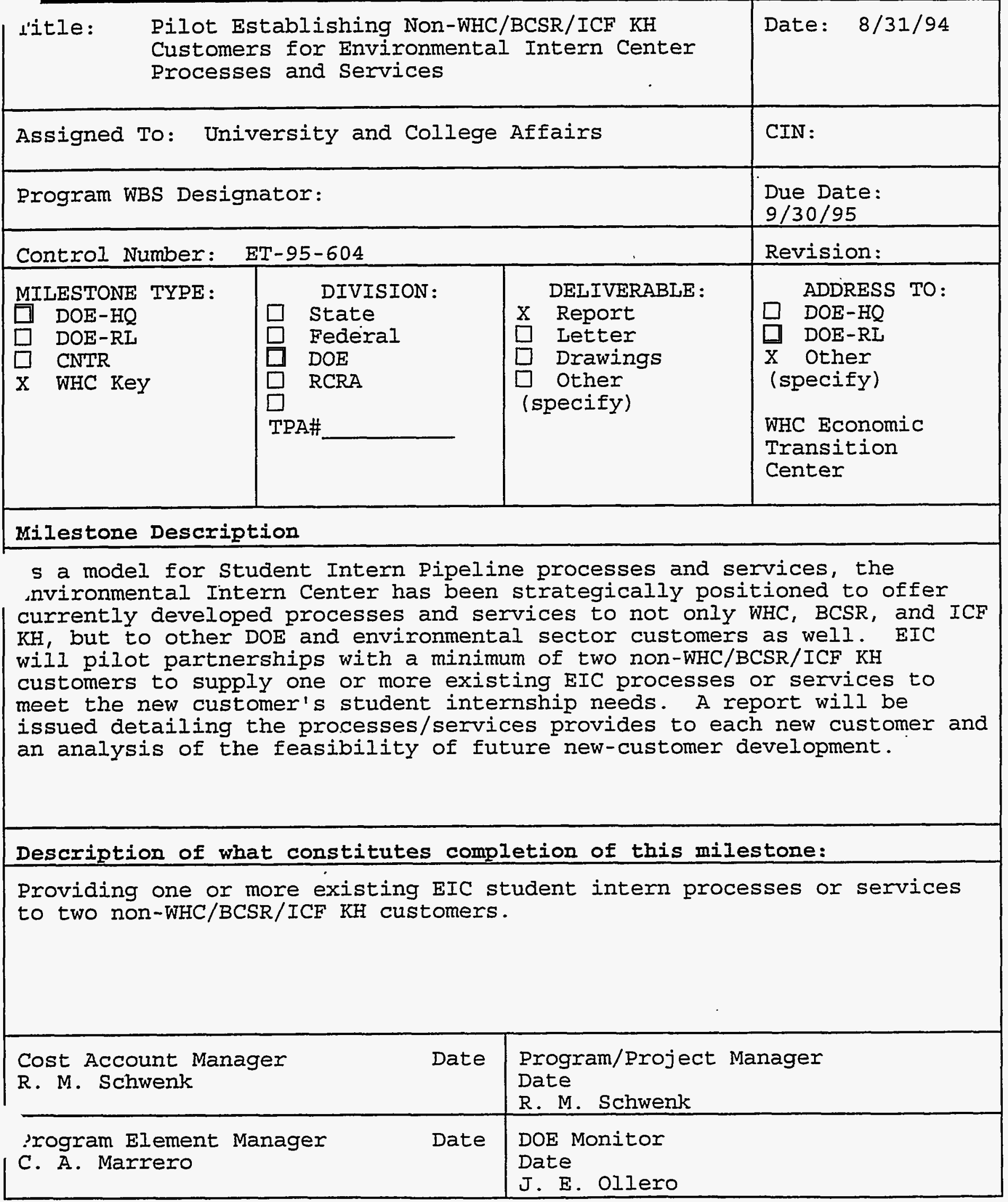


Westinghouse Hanford Company MILESTONE DESCRIPTION SHEET

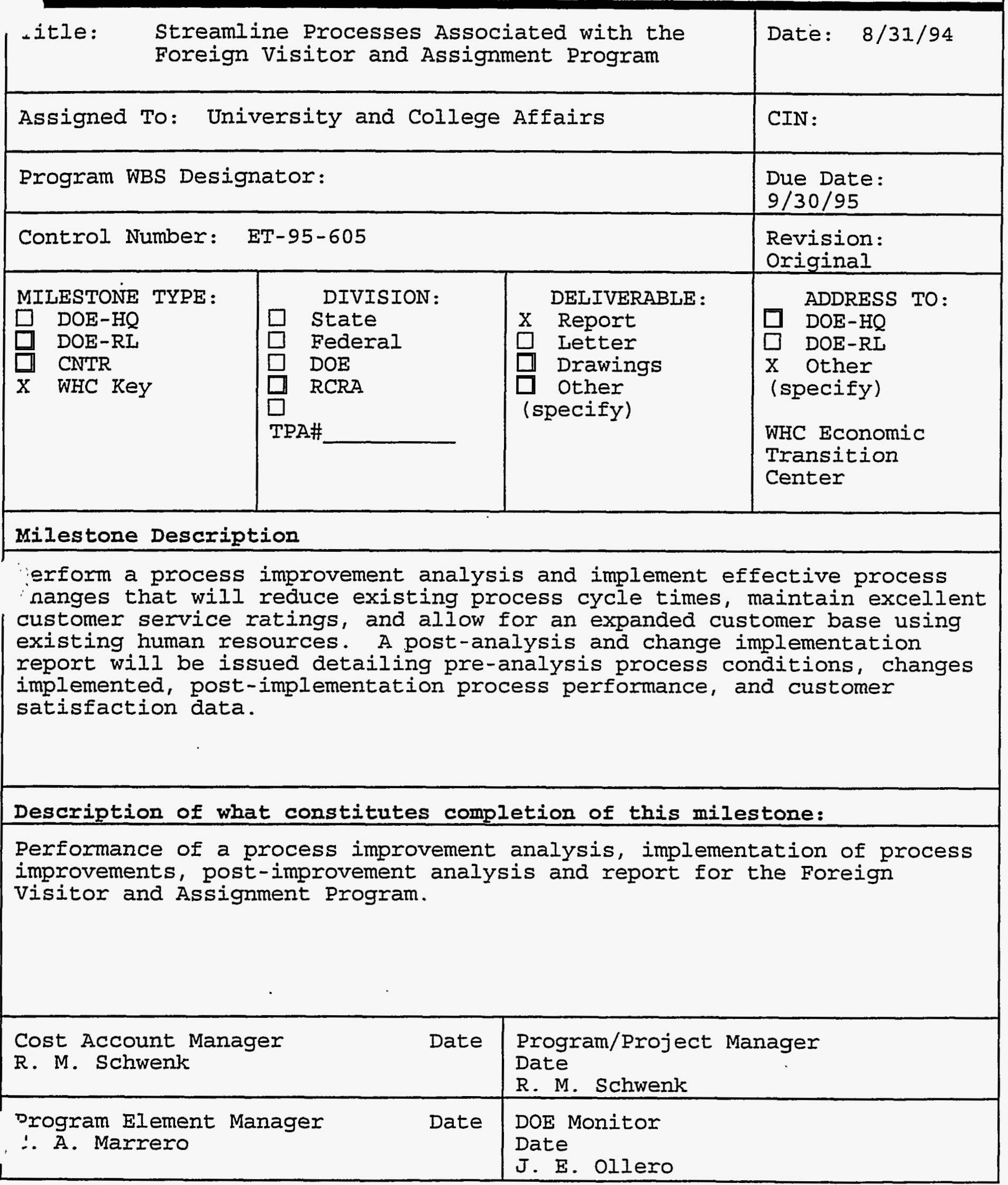


Iitle: Grant and Funding Research, and Application

Date: $08 / 31 / 94$ Submittal for projects of the office of Special Programs.

\begin{tabular}{ll|l}
\hline Assigned To: D. G. Carter & CIN:
\end{tabular}

Program WBS Designator:

Due Date: $09 / 30 / 95$

Control Number: ET-95-701

MILESTONE TYPE: DIVISION :

$\square \quad \mathrm{DOE}-\mathrm{HQ}$

$\square$ DOE-RL

CNTR
$\mathrm{X}$ WHC Key

$\square$ State

$\square \quad$ Federal

$\square$ DOE

$\square$ RCRA

TPA\#

Revision:

$\begin{array}{ll} & \text { DELIVERABIE: } \\ \square & \text { Report } \\ \square \text { Ietter } \\ \square \text { Drawings } \\ X \text { Other } \\ \text { (specify) }\end{array}$

Deliverable will depend upon each funding source's requi rements for application. This may or may or may not include. such items as a proposal, a letter of intent, and in some cases a presentation to the granting board. Once a grant is received, the granter may or may not require some sort of

feedback on progress; and in which form this may be required in unknown at this time, but will be provided if needed.

\section{Milestone Description}

Research, write, and submit 40 applications for grants and funding, to support the projects of the Office of Special Programs, from private, corporate, and governmental sources.

Description of what constitutes completion of this milestone:

1. Completion of this Milestone will be evident when 40 applications have been submitted for grants and/or funding to the granting organization.

2. Completion of this milestone is contingent upon available applicant status as it relates to application restrictions.

3. Completion of this Milestone is not contingent upon receiving grants and funding, because that step in the process is not controlled by the Office of Special Programs.

Cost Account Manager 1. G. Carter

Program Element Manager R. M. Schwenk
Date Program/Project Manager

Date

R. M. Schwenk

Date DOE Monitor

Date

J. E. OIlero 